Compiled by

Robert W. Buddemeier

Dana Isherwood

April 1985

$$
\text { DO NOT MAVROFL }
$$

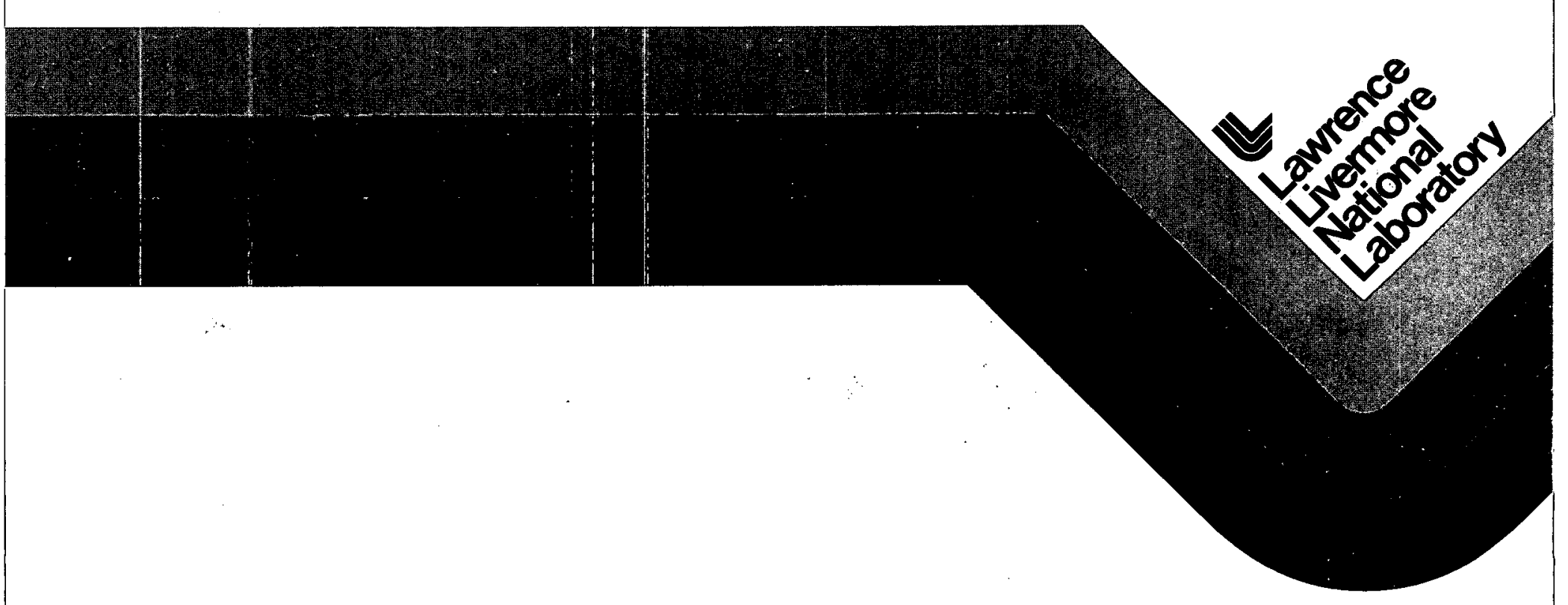




\section{DISCLAIMER}

This report was prepared as an account of work sponsored by an agency of the United States Government. Neither the United States Government nor any agency Thereof, nor any of their employees, makes any warranty, express or implied, or assumes any legal liability or responsibility for the accuracy, completeness, or usefulness of any information, apparatus, product, or process disclosed, or represents that its use would not infringe privately owned rights. Reference herein to any specific commercial product, process, or service by trade name, trademark, manufacturer, or otherwise does not necessarily constitute or imply its endorsement, recommendation, or favoring by the United States Government or any agency thereof. The views and opinions of authors expressed herein do not necessarily state or reflect those of the United States Government or any agency thereof. 


\section{DISCLAIMER}

Portions of this document may be illegible in electronic image products. Images are produced from the best available original document. 
This document was prepared as an account of work sponsored by an agency of the United States Government. Neither the United States Government nor the University of California nor any of their employees, makes any warranty, express or implied, or assumes any legal liability or responsibility for the accuracy, completeness, or usefulness of any information, apparatus, product, or process disclosed, or represents that its use would not infringe privately owned rights. Reference herein to any specific commercial products, process, or service by trade name, trademark, manufacturer, or otherwise, does not necessarily constitute or imply its endorsement, recommendation, or favoring by the United States Government or the University of California. The views and opinions of authors expressed herein do not necessarily state or reflect those of the United States Government or the University of California, and shall not be used for advertising or product endorsement purposes.

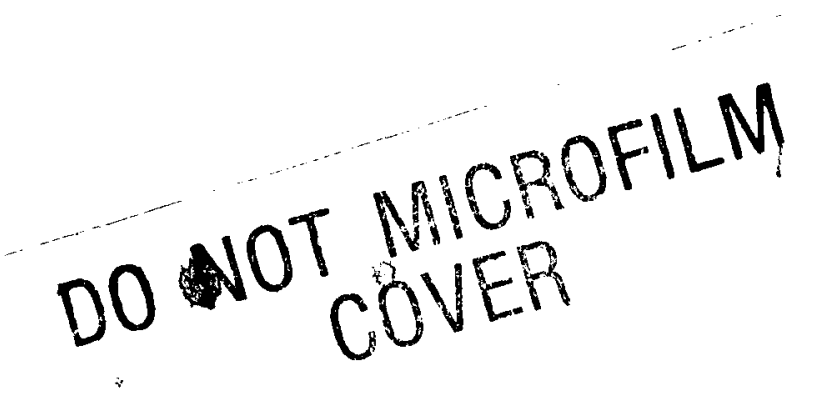

Work performed under the auspices of the U.S. Department of Energy by Lawrence Livermore National I aboratory under Contract W-7405-Eng-48. 
UCRL-53628

Distribution Category UC-11

UCRL --53628

DE85 017383

\title{
Radionuclide Migration Project 1984 Progress Report
}

\author{
Compiled by
}

Robert W. Buddemeier

Dana Isherwood

\section{Manuscript date: Aprill 1985}

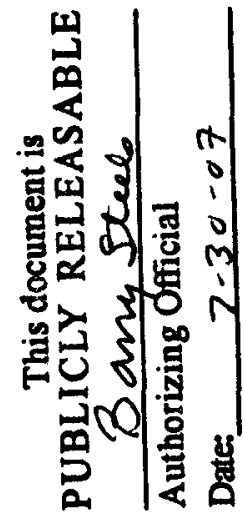

\section{DISCLAIMER}

This report was prepared as an account of work sponsored by an agency of the United States Government. Neither the United States Government nor any agency thereof, nor any of their employees, makes any warranty, express or implied, or assumes any legal liability or responsibility for the accuracy, completeness, or usefulness of any information, apparatus, product, or process disclosed, or represents that its use would not infringe privately owned rights. Reference herein to any specific commercial product, process, or service by trade name, trademark, manufacturer, or otherwise does not necessarily constitute or imply its endorsement, recommendation, or favoring by the United States Government or any agency thereof. The views and opinions of authors expressed herein do not necessarily state or reflect those of the United States Government or any agency thereof.

\section{LAWRENCE LIVERMORE NATIONAL LABORATORY University of California - Livermore, California $\cdot 94550$}

Available from: National Technical Information Service • U.S. Department of Commerce 5285 Port Royal Road $\bullet$ Springfield, VA $22161 \bullet \$ 10.00$ per copy $\bullet$ (Microfiche $\$ 4.50$ ) 


\section{Acknowledgments}

In the sections of this report that present data or interpretational results, the individuals who made significant scientific or technical contributions to the specific effort are listed as contributors. Many others, however, have provided general support, assistance, and advice important to the overall report. We gratefully acknowledge the contributions of the following organizations and individuals:

Lawrence Livermore National Laboratory: L. Ramspott, C. Gatrousis, K. Marsh, P. Mead, L. Boone, C. Martin, N. Crow, D. Grzybicki, M. Fowler, and J. Schweiger

Los Alamos National Laboratory: J. Thompson and his coworkers in INC11

Desert Research Institute (DRI): R. Jacobson, S. Tyler, and the field support team at DRI-Las Vegas.

U.S. Geological Survey: Wayne Evert

Reynolds Electrical and Engineering Co., Inc.: Environmental Sciences Department personnel

Department of Energy-Nevada Operations Office: T. Humphrey and J. Burrows

Dr. Richard C. Evans, of Alabama A\&M University, worked on the project while he was a visiting researcher at LLNL supported by the Office of Equal Opportunity. 


\section{Contents}

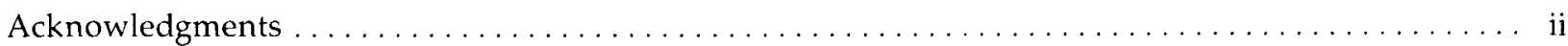

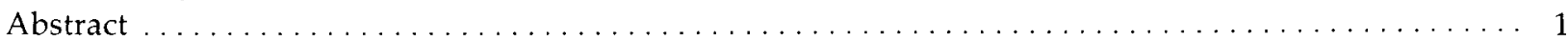

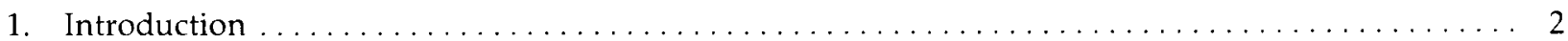

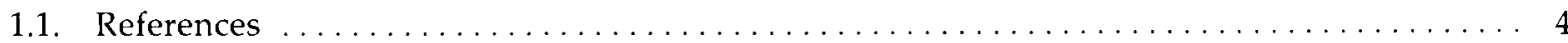

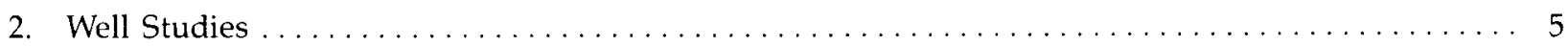

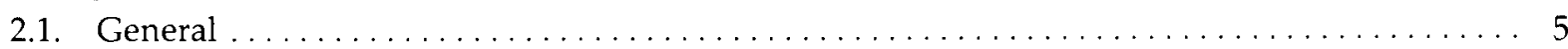

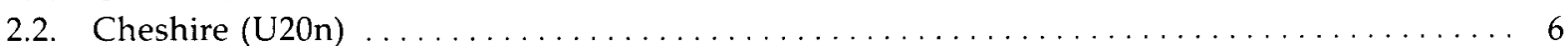

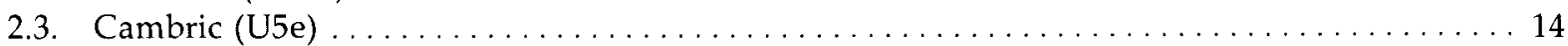

2.4. Nash (UE2ce) . . . . . . . . . . . . . . . . . . . . . . . . . . . . . . . . . 16

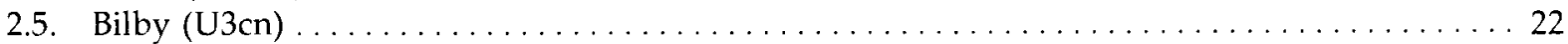

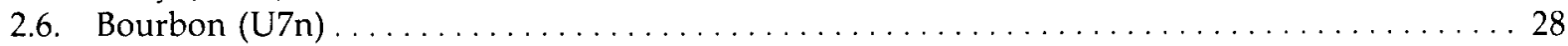

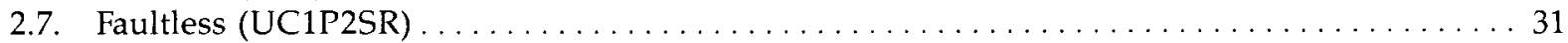

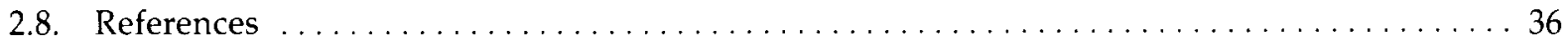

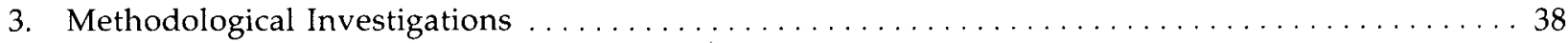

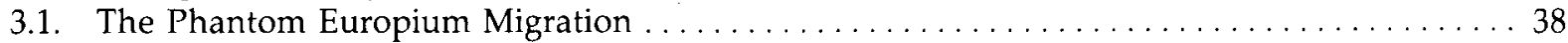

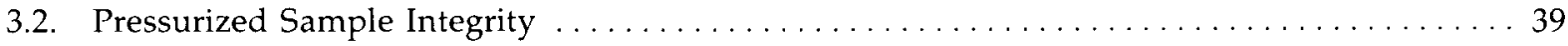

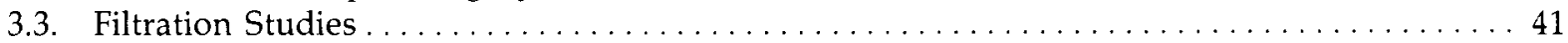

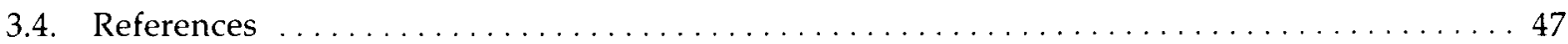

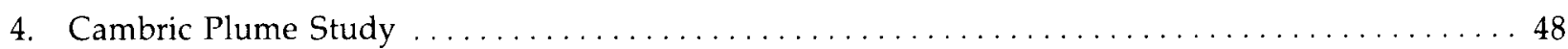

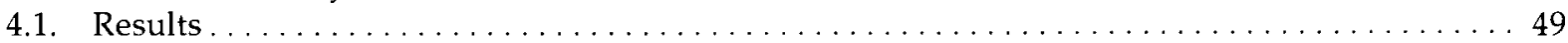

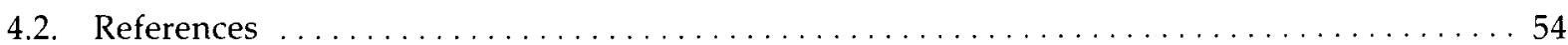

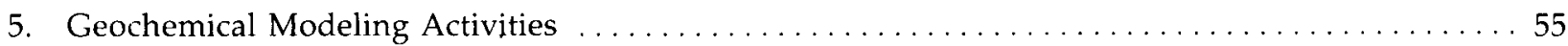

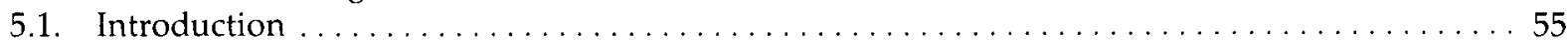

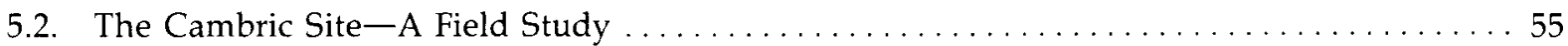

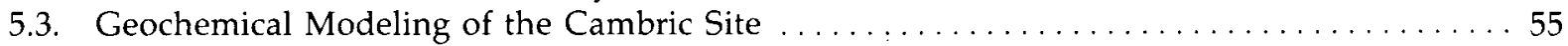

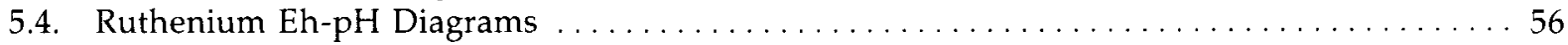

5.5. Technetium Geochemistry ..................................... 57

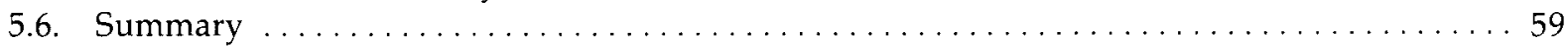

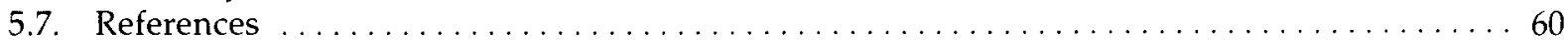

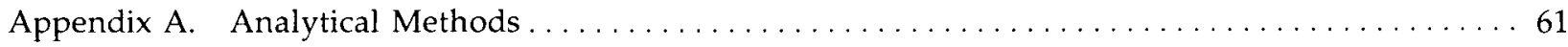

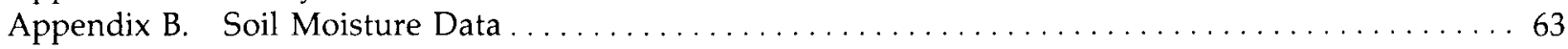




\title{
Radionuclide Migration Project 1984 Progress Report
}

\begin{abstract}
This report presents previously unpublished results from the Lawrence Livermore National Laboratory's participation in the Radionuclide Migration Project at the Nevada Test Site (NTS). The report discusses the hydrogeologic settings and histories of studies associated with the Cheshire (U20n), Cambric (U5e), Nash (UE2ce), Bilby (U3cn), Bourbon (U7n), and Faultless (UC1) Events. Radionuclide and some chemical data are presented for water samples from cavity or chimney wells associated with the Cheshire, Cambric, and Bilby Events, and from satellite wells at the Cambric, Nash, Bilby, Bourbon, and Faultless Event sites.

The report also gives the results of studies of specific sampling or analytical methodologies. These studies demonstrated that the apparent migration of ${ }^{155} \mathrm{Eu}$ is an artifact of spectrometric misidentification of gamma- and x-ray peaks from other constituents. A potential problem with atmospheric contamination of samples collected with evacuated thief samples was also identified. Ultrafiltration techniques were applied to some of the Cheshire cavity samples collected, and preliminary results suggest that substantial amounts of activity may be associated with colloidal particles in the size range of 0.006 to $0.45 \mu \mathrm{m}$.

A study has begun of the recharge of effluent water from RNM-2S (Cambric satellite well) into the desert floor as a result of nine years of continuous pumping. This report gives the initial results of unsaturated zone studies showing the propagation of moisture and tritium fronts through the shallow soil.

Geochemical modeling of the behavior of ruthenium and technetium was carried out, with particular emphasis on the identification of ionic species that would be potentially mobile under NTS ground-water conditions. The report compares the results with observations of ruthenium migration to the Cambric satellite well.
\end{abstract}




\section{Introduction}

This report presents the results of technical studies conducted by the Lawrence Livermore National Laboratory (LLNL) as part of the Radionuclide Migration (RNM) Project at the Nevada Test Site (NTS). The RNM Project is intended to assess the potential for radionuclide migration away from the underground nuclear test cavities at NTS, with particular emphasis on issues relating to ground-water contamination and transport. Figure 1-1 shows the locations of the sites and wells studied at NTS.

The project, which was initiated in 1974 , continues as a multi-agency research project [LLNL, Los Alamos National Laboratory (LANL), the Desert Research Institute (DRI) of the University of Nevada, and the U.S. Geological Survey (USGS)] coordinated by the Nevada Operations Office of the U.S. Department of Energy (DOENVOO).

The agencies involved in the project have issued a variety of letter reports, technical reports, and scientific publications on aspects of RNM studies. LLNL has published a variety of topical reports, ${ }^{1-16}$ but like other agencies involved has documented some of the results of ongoing studies in the form of letter reports and informal presentations.

The present report is intended to accomplish three objectives:

1. It is a comprehensive annual report of LLNL activities and results for the RNM project during FY84.
2. It summarizes the results of LLNL studies done in previous fiscal years that have not appeared in formal technical reports.

3. It provides basic background information and a compilation of data reported by other agencies for ongoing studies for which no comprehensive or recent report exists.

The report is organized on a topical basis. Section 2 summarizes the results of field studies of NTS wells selected for study of possible radionuclide migration. Section 3 reports the results of field and laboratory experiments designed to evaluate or improve sampling and analytical techniques and to resolve specific questions of data interpretation. Section 4 describes a program initiated to use the ongoing Cambric pumping experiment to study recharge and tritium transport phenomena in an alluvial medium. Section 5 presents the results of geochemical modeling of ruthenium and technetium mobility in the context of the Cambric pumping experiment.

In addition to topical discussions and interpretations, the status of the various studies (completed or continuing) is indicated. Because this is an update report rather than a comprehensive review, the depth of treatment of the RNM well studies varies, depending on the availability of prior reports. 


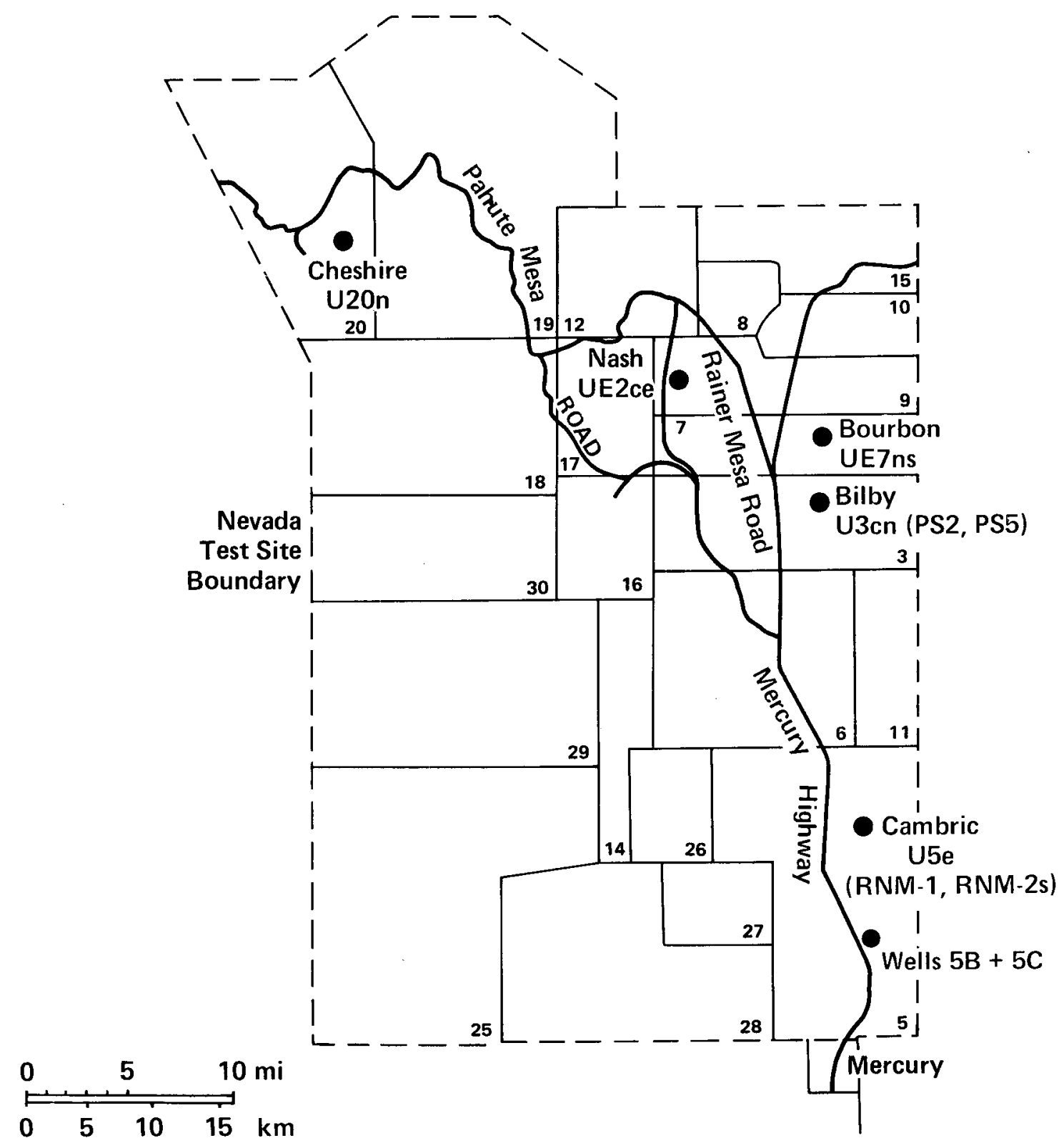

Figure 1-1. Locations of experimental sites described in this report. Small numbers indicate NTS areas. 


\subsection{References}

1. Borg, I., R. Stone, H. B. Levy, and L. D. Ramspott, 1976, Information Pertinent to the Migration of Radionuclides in Ground Water at the Nevada Test Site. Part 1: Review and Analysis of Existing Information, Lawrence Livermore National Laboratory, Livermore, CA, UCRL-52078.

2. Borg, I., R. Stone, H. B. Levy, and L. D. Ramspott, 1976, Information Pertinent to the Migration of Radionuclides in Ground Water at the Nevada Test Site. Part 2: Annotated Bibliography, Lawrence Livermore National Laboratory, Livermore, CA, UCRL-52078.

3. Borg, I., R. Stone, H. B. Levy, and L. Ramspott, 1977, "Movement of Radioactivity Deposited at the U.S. ERDA Nevada Test Site," Transactions and Proceedings of Transfer of Nuclear Technology Conference (Atomic Energy Organization of Iran, April 10-14, 1977).

4. Borg, I. Y., 1972, Extent of Pervasive Fracturing Around an Underground Nuclear Explosion, Lawrence Livermore National Laboratory, Livermore, CA, UCRL-73831 (preprint).

5. Borg, I. Y., 1975, "Radioactivity Trapped in Melt Produced by a Nuclear Explosion," Nuclear Technology 26, No. 6, pp. 88-100.

6. Coles, D., 1981, "A Continuous-Flow Leach Testing Method for Various Nuclear Waste Forms," Nuclear and Chemical Waste Management 2, pp. 245-252.

7. Coles, D., and L. Ramspott, 1982, "Migration of Ruthenium-106 in a Nevada Test Site Aquifer: Discrepancy Between Field and Laboratory Results," Science 215, pp. 1235-1237.

8. Coles, D., H. Weed, D. Jackson, and J. Schweiger, 1978, Single-Pass Leaching of Nuclear Melt Glass by Groundwater, Lawrence Livermore National Laboratory, Livermore, CA, UCRL-81617. Also in Radioactive Waste in Geologic Storage, p. 93, S. Fried, Ed. (ACS Symposium Series 100, 1978).

9. Crow, N., 1976, First Observations of Tritium in Ground Water Outside Chimneys of Underground Nuclear Explosions, Yucca Flat, Nevada Test Site, Lawrence Livermore National Laboratory, Livermore, CA, UCRL-50273.

10. Failor, R., D. Coles, and J. Rego, 1983, A Leaching Study of Nuclear Melt Glass: Part I, Lawrence Livermore National Laboratory, Livermore, CA, UCID-19729.

11. Isherwood, D., 1985, Application of the Ruthenium and Technetium Thermodynamic Data Bases Used in the EQ3/6 Geochemical Codes, Lawrence Livermore National Laboratory, Livermore, CA, UCRL53594.

12. Ramspott, L., and I. Borg, 1977, Underground Nuclear Tests Below the Water Table as Waste Disposal Pilot Plants, Geological Society of America Annual Meeting, Symposium on Hydrogeology of Radioactive Waste Disposal (Seattle, Washington, Nov. 7-9, 1977), Lawrence Livermore National Laboratory, Livermore, CA, UCRL-79632.

13. Ramspott, L., J. Tewhey, D. Coles, H. Weed, J. Schweiger, and R. Stone, 1979, FY-78 Annual Technical Report of Lawrence Livermore National Laboratory's Participation in the DOE-NV Project: Radionuclide Migration in the Ground, Lawrence Livermore National Laboratory, Livermore, CA, UCID-18259.

14. Rard, J., 1985, "Chemistry and Thermodynamics of Ruthenium and Some of its Inorganic Compounds and Aqueous Species," Chemical Reviews 85, pp. 1-39.

15. Rard, J., 1983, Critical Review of the Chemistry and Thermodynamics of Technetium and Some of its Inorganic Compounds and Aqueous Species, Lawrence Livermore National Laboratory, Livermore, CA, UCRL-53440.

16. Weed, H., and D. Jackson, 1979, Design of a Variable Flow-Rate, Single Pass Leaching System, Lawrence Livermore National Laboratory, Livermore, CA, UCRL-52785. 


\section{Well Studies}

\subsection{General}

\subsubsection{Sampling and Blanks}

\section{(Contributors: J. Rego and R. W. Buddemeier)}

This section describes the sample collection, processing, and analytical methods generally used for the RNM well samples. Unique or highly specific methods are described in the appropriate sections.

One of the mainstays of the LLNL RNM field program has been low-level gamma spectrometry of the salts from evaporated large-volume water samples. This approach provides high sensitivity for a variety of gamma-emitting nuclides of interest. Because it is more time-efficient than radiochemical separation, it permits us to screen substantial numbers of samples for evidence of radionuclide migration.

Two different approaches to sample evaporation are employed. One method consists of field collection of samples in one or more new plasticlined 55-gal drums. These drums are forwarded to LLNL, where the water is evaporated by addition of successive aliquots to stainless-steel drying pans in a specially designed oven located in a building remote from any locations where active handling of radioactive materials is conducted. The evaporated salts are composited and homogenized by hand, then packed into standard sample containers for gamma counting. These water samples are generally unfiltered, but have on occasion been filtered in the laboratory through $0.45-\mu \mathrm{m}$ Millepore or Nuclepore filters. In the data tables in this and the following sections, these samples are identified by the term "filter used." Those with no filter indicated or a filter size other than $1.0-\mu \mathrm{m}$ are laboratory-evaporated samples, unless otherwise specified in the text. To minimize the possibilities of contamination, the drums are not reused, and the evaporation trays are thoroughly decontaminated between samples and are segregated according to whether they have been used for high- or low-activity samples.

The other evaporation system used is a field evaporator with a metered flow input through a $1.0-\mu \mathrm{m}$ cartridge filter. The evaporator is a stainless-steel tank heated by gas-fired burners. The collected salt slurry is removed by hand and returned to LLNL in a stainless steel container for final oven drying, homogenization, packaging, and counting. The field sampler is flushed and de- contaminated between samples and is used only for low-activity (satellite well) samples to minimize the possibility of cross-contamination. The tabulated data identified as results of a sample passed through a $1.0-\mu \mathrm{m}$ filter are field evaporator samples, unless otherwise noted.

In determining the extremely low levels of activity present in some of the RNM satellite wells, the issue of an appropriate blank or background value becomes extremely important. The problems of establishing the filter blanks and of assigning observed activity to either dissolved or particulate fractions is discussed in some detail in Section 3.3.

Although scrupulous care is taken in correcting for detection system backgrounds and in processing the samples, the potential for sample contamination is always present, especially in view of the known surface contamination at NTS.

To obtain empirical estimates of a "field" blank, two large-volume water samples have been processed from water supply wells $5 \mathrm{~B}$ and $5 \mathrm{C}$, located in Frenchman Flat and completed to a depth of $230 \mathrm{~m}$ in the alluvial aquifer. The nearest detonation cavity is Cambric, which is $2.4 \mathrm{~km}$ upgradient. Because of the lack of significant transport observed in the Cambric pumping experiment, we have assumed that no subsurface contamination sources affect wells $5 \mathrm{~B}$ and $5 \mathrm{C}$.

The results of gamma analysis on the two evaporated large-volume water samples are presented in Table 2-1. The first, a laboratoryevaporated sample, showed no detectable activity; the second sample, collected using the field evaporator, indicated only a very low concentration of ${ }^{137}$ Cs.

The level of ${ }^{137} \mathrm{Cs}$ seen is comparable to that observed in most of the satellite well samples, independent of the presence of any other nuclides. We believe that these measurements are real and that they represent unavoidable contamination from the ubiquitous surface ${ }^{137} \mathrm{Cs}$ at NTS. This is particularly true for field evaporator samples, which are somewhat more vulnerable to contamination by resuspended soil than are the drumcollected samples.

Any low-level counting evidence for radionuclide migration should be validated by repeated measurements, and ${ }^{137} \mathrm{Cs}$ in particular must be considered suspect at any concentration below several tenths of a dpm/L. 
Table 2-1. Results of gamma analysis of well water at NTS wells $5 B$ and 5C.

\begin{tabular}{|c|c|c|c|c|c|c|c|c|c|c|c|c|c|}
\hline \multirow{2}{*}{$\begin{array}{c}\text { Sampling } \\
\text { date }\end{array}$} & \multirow{2}{*}{$\begin{array}{c}\text { Solution } \\
\text { vol (L) } \\
\text { [salt } \\
\text { wt }(g)]\end{array}$} & \multirow{2}{*}{$\begin{array}{c}\text { Filter } \\
\text { used }\end{array}$} & \multicolumn{10}{|c|}{$\mathrm{dpm} / \mathrm{L}( \pm 1$ std $\mathrm{dev} \%)$} & \multirow{2}{*}{$\begin{array}{c}\text { Ratio } \\
{ }^{235} U{ }^{238} U\end{array}$} \\
\hline & & & ${ }^{22} \mathrm{Na}$ & ${ }^{40} \mathrm{~K}$ & ${ }^{60} \mathrm{Co}$ & ${ }^{106} \mathrm{Ru}$ & ${ }^{125} \mathrm{Sb}$ & ${ }^{137} \mathrm{Cs}$ & ${ }^{155} \mathrm{Eu}$ & ${ }^{3} \mathrm{H}$ & ${ }^{235} \mathbf{U}$ & ${ }^{238} \mathrm{U}$ & \\
\hline $11 / 29 / 78$ & $\begin{array}{l}200.0 \\
{[158]}\end{array}$ & - & $<0.002$ & $\begin{array}{l}19.25 \\
(2.20 \%)\end{array}$ & $<0.002$ & $<0.07$ & $<0.02$ & $<0.004$ & $<0.004$ & $\mathbf{N A}^{\mathbf{a}}$ & $\begin{array}{l}0.16 \\
(5.60 \%)\end{array}$ & $\begin{array}{l}4.33 \\
(4.80 \%)\end{array}$ & 0.038 \\
\hline $4 / 15 / 82$ & $\begin{array}{l}515.0 \\
{[182]}\end{array}$ & $1.0 \mu \mathrm{m}$ & $<0.002$ & $\begin{array}{l}17.60 \\
(1.00 \%)\end{array}$ & $<0.002$ & $<0.1$ & $<0.01$ & $\begin{array}{l}0.04 \\
(5.70 \%)\end{array}$ & $<0.004$ & NA & $\begin{array}{l}0.22 \\
(1.50 \%)\end{array}$ & $\begin{array}{l}2.88 \\
(5.20 \%)\end{array}$ & 0.076 \\
\hline
\end{tabular}

${ }^{\mathrm{a}} \mathrm{NA}=$ Not analyzed.

\subsubsection{Contract Analyses}

(Contributors: R. Failor, J. Rego, and R. W. Buddemeier)

During 1983, aliquots of several archived salts from LLNL's large-volume RNM water samples were submitted to EAL Corporation (Richmond, Calif.) for low-level ${ }^{90} \mathrm{Sr}$ and plutonium analyses.

The archived salts were redried, mixed, and weighed; then weighed aliquots were taken for submission. One aliquot of Well $5 B / 5 C$ salts was included as a blank; a mixture of reagent-grade salts approximating the composition of NTS ground water was prepared and used for substrates for submission of known activity blind standards. Measured volumes of ${ }^{90} \mathrm{Sr}$ and Pu standard solutions were distributed from a pipet over the surfaces of the salt samples, which were then dried and homogenized. EAL dissolved and analyzed the samples by standard techniques that have been shown to compare well with LLNL inhouse methods. ${ }^{1}$ Because of the need to evaluate the sample data in the context of the blank and blind standard results, the data are presented here as a group in Table 2-2. Individually significant results are also included in relevant sections on specific wells.

Table 2-2 summarizes the results, correcting the decays to a reference time of July 1, 1983. Uncertainties are one standard deviation based on counting statistics only, and the weights are the oven-dried weights of the aliquot analyzed. The "equivalent volume" column gives the volume of the original water sample represented by the amount of salt analyzed, based on total volumes and salt weights for the original samples (see appropriate sections on individual wells). In assessing the results, it should be kept in mind that the original water samples were either not filtered or filtered only through a $1-\mu \mathrm{m}$ cartridge, so that observed activities may be associated with suspended particles even though we treat them by convention as being dissolved.
On the basis of the ${ }^{239 / 240} \mathrm{Pu}$ data, we conclude that salt concentrations less than $10^{-3} \mathrm{pCi} / \mathrm{g}$ are indistinguishable from the blank, values in the $1-10 \times 10^{-3}$ range are indicative of the presence of $\mathrm{Pu}$ but quantitatively uncertain, and results in excess of $10^{-2} \mathrm{pCi} / \mathrm{g}$ are probably reasonably accurate. Based on this, none of the satellite wells shows any evidence of $\mathrm{Pu}$, but positive results are definitely found for the Cambric cavity and probably for the Bilby chimney.

Evaluation of the ${ }^{90} \mathrm{Sr}$ data is somewhat more difficult. Most of the samples show apparent activity greater than that of the blank, but LANL has consistently reported ${ }^{90} \mathrm{Sr} \leq$ background in Cambric satellite samples, and no other radionuclides have been detected in the Bilby satellite (see Section 2.5), leading us to suspect that ${ }^{90} \mathrm{Sr}$ has not migrated to these wells. This finding, in conjunction with the relatively poor agreement for the spiked salt results and the Bilby satellite duplicates, indicates that about $10^{-1} \mathrm{pCi} / \mathrm{g}$ is probably the low limit for reliable results. This assumption leaves us with definite ${ }^{90} \mathrm{Sr}$ in the Cambric cavity (RNM-1) and the Nash satellite, and probably in the Bilby chimney as well. The other results must be considered inconclusive.

\subsection{Cheshire (U20n)}

(Contributors: R. W. Buddemeier, J. Rego, and J. Schweiger)

The Cheshire (U20n) Event was fired on February 14, 1976, with an announced yield in the 200- to 500-kt range. The site is on Pahute Mesa within the Silent Canyon Caldera formation. The device was detonated at a depth of $1167 \mathrm{~m}$ in a rhyolitic formation. The preshot water level was at a depth of $630 \mathrm{~m}$.

The Cheshire site is of interest to the RNM program for three main reasons:

1. It is the only study site in tuff (as opposed to alluvium or carbonate aquifers). 
Table 2-2. Results of sample analyses of 12 archived salts.

\begin{tabular}{|c|c|c|c|c|c|c|c|c|}
\hline \multirow[b]{2}{*}{ Sample No. } & \multirow[b]{2}{*}{ Source } & \multirow[b]{2}{*}{ Date } & \multirow[b]{2}{*}{ Salt wt (g) } & \multirow[b]{2}{*}{ Equiv vol (L) } & \multicolumn{2}{|l|}{${ }^{90} \mathrm{Sr}$} & \multicolumn{2}{|c|}{${ }^{239-240} \mathrm{Pu}$} \\
\hline & & & & & $\overline{\mathrm{pCi}} / \mathrm{g}( \pm 1$ std dev $\%)$ & $\mathrm{pCi} / \mathrm{mL}$ & $\overline{\mathrm{pCi} / \mathrm{g}( \pm 1 \text { std dev } \%)}$ & $\mathrm{pCi} / \mathrm{mL}$ \\
\hline 1 & Wells 5A/5B (blank) & $4 / 15 / 82$ & 132.5 & 375 & $\begin{array}{l}4.92 \times 10^{-3} \\
(21.1 \%)\end{array}$ & $1.74 \times 10^{-6}$ & $\begin{array}{l}7.04 \times 10^{-4} \\
(20.9 \%)\end{array}$ & $2.49 \times 10^{-9}$ \\
\hline 2 & Bilby chimney & $10 / 21 / 81$ & 45.7 & 134 & $\begin{array}{l}1.66 \times 10^{-1} \\
(15.1 \%)\end{array}$ & $5.66 \times 10^{-5}$ & $\begin{array}{l}6.90 \times 10^{-3} \\
(12.7 \%)\end{array}$ & $2.35 \times 10^{-6}$ \\
\hline 3 & Bilby satellite & $10 / 21 / 80$ & 134.6 & 343 & $\begin{array}{l}5.73 \times 10^{-3} \\
(7.2 \%)\end{array}$ & $2.25 \times 10^{-6}$ & $\begin{array}{l}6.49 \times 10^{-4} \\
(25.2 \%)\end{array}$ & $2.55 \times 10^{-7}$ \\
\hline 9 & Bilby satellite & $10 / 21 / 80$ & 138.6 & 353 & $\begin{array}{l}1.63 \times 10^{-2} \\
(6.9 \%)\end{array}$ & $6.40 \times 10^{-6}$ & $\begin{array}{l}5.43 \times 10^{-4} \\
(23.7 \%)\end{array}$ & $2.13 \times 10^{-7}$ \\
\hline 4 & Bilby satellite & $10 / 21 / 81$ & 105.7 & 348 & $\begin{array}{l}9.68 \times 10^{-3} \\
(17.5 \%)\end{array}$ & $2.94 \times 10^{-6}$ & $\begin{array}{l}6.96 \times 10^{-4} \\
(23.7 \%)\end{array}$ & $2.11 \times 10^{-7}$ \\
\hline 6 & $\begin{array}{l}\text { Nash satellite } \\
\text { (UE2ce) }\end{array}$ & $10 / 9 / 80$ & 111.4 & 315 & $\begin{array}{l}1.77 \\
(1.5 \%)\end{array}$ & $6.26 \times 10^{-4}$ & $\begin{array}{l}5.49 \times 10^{-4} \\
(26.9 \%)\end{array}$ & $1.94 \times 10^{-7}$ \\
\hline \multirow[t]{6}{*}{12} & $\begin{array}{l}\text { Nash satellite } \\
\text { (UE2ce) }\end{array}$ & $10 / 9 / 80$ & 114.2 & 323 & $\begin{array}{l}1.61 \\
(1.9 \%)\end{array}$ & $5.69 \times 10^{-4}$ & $\begin{array}{l}3.14 \times 10^{-4} \\
(40.1 \%)\end{array}$ & $1.11 \times 10^{-7}$ \\
\hline & $\begin{array}{l}\text { Nash satellite } \\
\text { (UE2ce) }\end{array}$ & $2 / 22 / 82$ & 109.0 & 263 & $\begin{array}{l}1.19 \\
(2.1 \%)\end{array}$ & $4.93 \times 10^{-4}$ & $\begin{array}{l}1.09 \times 10^{-4} \\
(75.1 \%)\end{array}$ & $4.52 \times 10^{-8}$ \\
\hline & $\begin{array}{l}\text { Cambric cavity } \\
\text { (RNM-1) }\end{array}$ & $10 / 5 / 81$ & 46.6 & 205 & $\begin{array}{l}5.74 \times 10^{1} \\
(1.2 \%)\end{array}$ & $1.30 \times 10^{-2}$ & $\begin{array}{l}1.34 \times 10^{-2} \\
(8.1 \%)\end{array}$ & $3.05 \times 10^{-6}$ \\
\hline & $\begin{array}{c}\text { Cambric satellite } \\
\text { (RNM-2S) }\end{array}$ & $11 / 10 / 82$ & 82.0 & 313 & $\begin{array}{l}5.83 \times 10^{-2} \\
(15.1 \%)\end{array}$ & $1.53 \times 10^{-5}$ & $\begin{array}{l}6.98 \times 10^{-4} \\
(31.4 \%)\end{array}$ & $1.83 \times 10^{-7}$ \\
\hline & & & & & \multicolumn{2}{|c|}{${ }^{90} \mathrm{Sr}(\mathrm{pCi} / \mathrm{g})$} & \multicolumn{2}{|c|}{${ }^{239-240} \mathrm{Pu}(\mathrm{pCi} / \mathrm{g})$} \\
\hline & & & & & Spiked & Reported & Spiked & Reported \\
\hline 5 & $\begin{array}{l}\text { Spiked blank } \\
\text { (blind standard) }\end{array}$ & - & 99.1 & - & $1.93 \times 10^{-2}$ & $\begin{array}{l}1.38 \times 10^{-2} \\
(10.2 \%)\end{array}$ & $1.82 \times 10^{-3}$ & $\begin{array}{l}2.39 \times 10^{-3} \\
(13.6 \%)\end{array}$ \\
\hline 10 & $\begin{array}{l}\text { Spiked blank } \\
\text { (blind standard) }\end{array}$ & - & 49.3 & - & $3.87 \times 10^{-1}$ & $\begin{array}{l}2.15 \times 10^{-1} \\
(2.9 \%)\end{array}$ & $3.65 \times 10^{-2}$ & $\begin{array}{l}3.36 \times 10^{-2} \\
(4.8 \%)\end{array}$ \\
\hline
\end{tabular}


2. The detonation was more recent and larger than most of the other shots under investigation, thus providing a larger source term and a better opportunity to study the behavior of the short-lived radionuclides.

3. The site is only $8 \mathrm{~km}$ from the western boundary of NTS in a permeable formation with a surface water table gradient trending southwest, making it a likely candidate for relatively prompt off-site transport of radionuclides.

A re-entry hole (U20n PS 1DDH) was slant drilled during June and July 1976. The hole was sidewall cored and drilled to a total slant depth of $1378 \mathrm{~m}$ (vertical depth approximately $1287 \mathrm{~m}$; estimated to be $60 \mathrm{~m}$ below cavity bottom). The casing was perforated from 1322 - to $1321-\mathrm{m}$ slant depth (approximate vertical interval: 1195$1220 \mathrm{~m}$ ). A pump was installed at $1292-\mathrm{m}$ slant depth (1206 m vertical), and a water sample was pumped. On pullout, the pump stuck at $610 \mathrm{~m}$ and could not be dislodged. ${ }^{2}$ In March 1981, the pump was forced to the bottom of the hole and a bridge plug was set above it; the hole was then tested and found to be watertight. During July and August 1983 the hole was logged and scraped and the casing was perforated in the slant-depth interval between 1293 and $1306 \mathrm{~m}$ (vertical depth range $1206-1220 \mathrm{~m}$ ). The well was surged, pressurized samples were taken by LANL, and a pump was installed. An initial attempt to pump water samples in August 1983 was aborted when the pump failed. After installation of a new pump at a slant depth of $922 \mathrm{~m}$ (vertical depth $861 \mathrm{~m}$ ), the well was pumped between September 7 and 9, 1983. Teams from LANL, LLNL, USGS, and Reynolds Electrical and Engineering Co., Inc. (REECo) took samples and measurements during the pumping period. A total of 137,000 gal was pumped before the pump was shut down. Pumping and sampling were restarted on July 31, 1984; the results of this second test period will be reported later. REECo radionuclide analyses have been reported by letter. ${ }^{3}$ Table 2-3 summarizes the chronologic history of RNM studies, and Fig. 2-1 shows a vertical cross section of the experimental site.

\subsubsection{Results}

Although the initial sampling (1976) was intended to obtain water from below the lower boundary of the cavity in order to establish background activity levels, the samples contained ${ }^{89} \mathrm{Sr}$, ${ }^{90} \mathrm{Sr},{ }^{103} \mathrm{Ru},{ }^{106} \mathrm{Ru},{ }^{124} \mathrm{Sb},{ }^{125} \mathrm{Sb},{ }^{181} \mathrm{~W},{ }^{188} \mathrm{~W},{ }^{85} \mathrm{Kr},{ }^{239} \mathrm{Pu}$, and ${ }^{3} \mathrm{H}$ (tritium levels reached $2000 \mathrm{nCi} / \mathrm{mL}$ ), indicating that water had been drawn from or had already migrated below the cavity. ${ }^{4,5}$

During the September 1983 sampling period, LLNL analyzed samples in the field for dissolved oxygen (DO), temperature, Eh, $\mathrm{pH}$, and alkalinity by the methods described in Appendix A. Table 2-4 presents the results of these observations.

Table 2-3. Cheshire (U20n) chronology.

\begin{tabular}{|c|c|}
\hline Date & Chronology \\
\hline $2 / 14 / 76$ & Detonation, hole U20n; yield range $200-500 \mathrm{kt}$. Working point $1167 \mathrm{~m}$. \\
\hline $6 / 29 / 76$ & $\begin{array}{l}\text { Hole U20n PS 1DDH drilled to } 1287 \mathrm{~m} \text {. Cased to } 1284 \mathrm{~m} \text {. } \\
\text { Perforations } 1239-1247 ; 1254-1259 ; 1267-1272 .\end{array}$ \\
\hline $9 / 13 / 76$ & Pump installed at $1227 \mathrm{~m}$. Rate $=34 \mathrm{gal} / \mathrm{min}$. Quit $45 \mathrm{~min}$ later. \\
\hline $9 / 15 / 76$ & Pump pulled. \\
\hline $9 / 24 / 76$ & Pump started down hole but stuck at $610 \mathrm{~m}$ (top). \\
\hline $9 / 29 / 76$ & Sandia camera employed downhole. \\
\hline $10 / 4 / 76$ & All attempts to recover stuck pump unsuccessful, abandoned until funding available. \\
\hline $3 / 20 / 81$ & $\begin{array}{l}\text { Derelict pump pushed to the bottom of the hole; top of debris at } 1229 \mathrm{~m} \text {. Tubing } \\
\text { filled with tagged water. Pressure tested } 2-1 / 2 \mathrm{~d} \text {. }\end{array}$ \\
\hline $5 / 20 / 81$ & Casing full of water; awaiting pump. \\
\hline $9 / 7 / 83$ & $\begin{array}{l}\text { Perforations at } 1207 \text { and } 1220 \mathrm{~m} \text {; new pump installed at } 861 \mathrm{~m} \text {. Series of samples } \\
\text { taken by LLNL and LANL for field and laboratory measurements. Shut down } 9 / 9 / 83 \text {. }\end{array}$ \\
\hline $7 / 31 / 84$ & Pumping resumed. \\
\hline $8 / 1 / 84$ & LANL water collection. Rate $23 \mathrm{gal} / \mathrm{min}$. \\
\hline $10 / 23 / 84$ & Large-volume samples taken by LLNL and LANL prior to shutdown. \\
\hline
\end{tabular}




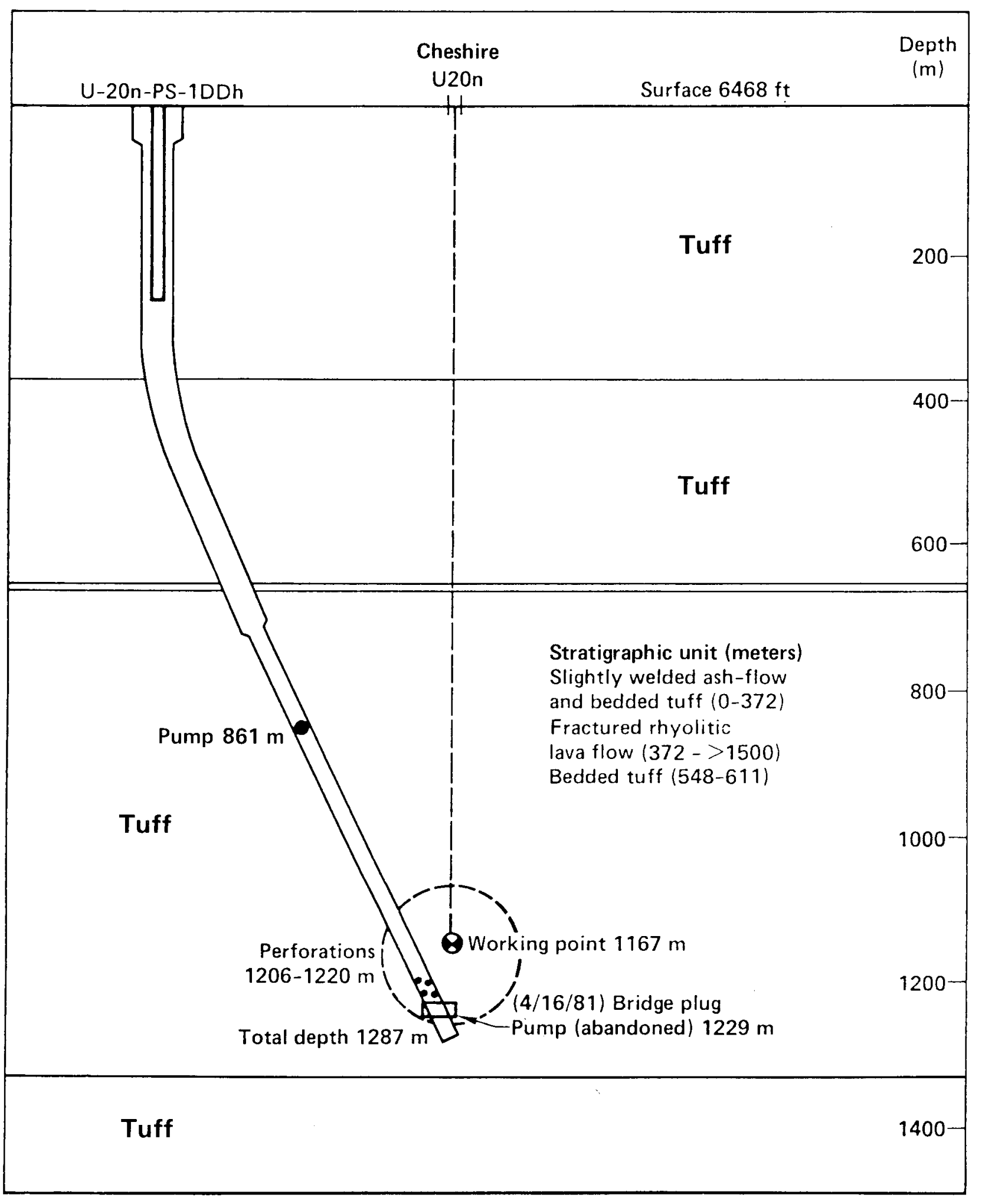

Figure 2-1. Cheshire site cross section. 
Table 2-4. Cheshire field measurements.

\begin{tabular}{|c|c|c|c|c|c|c|c|}
\hline \multirow{2}{*}{$\begin{array}{c}\text { Time } \\
\text { (h) }\end{array}$} & \multirow{2}{*}{$\begin{array}{l}\text { Meter } \\
\text { (gal) }\end{array}$} & \multirow{2}{*}{$\begin{array}{c}\text { DO } \\
\text { (ppm) }\end{array}$} & \multirow{2}{*}{$\begin{array}{l}\text { Temp } \\
\left({ }^{\circ} \mathrm{C}\right)\end{array}$} & \multirow{2}{*}{$\begin{array}{c}\text { Eh (mV) } \\
(\mathrm{vs} N H E)^{\mathrm{a}}\end{array}$} & \multirow[b]{2}{*}{$\mathrm{pH}$} & \multicolumn{2}{|c|}{ Alkalinity (ppm $\mathrm{CaCO}_{3}$ ) } \\
\hline & & & & & & $N^{b}$ & $\mathbf{F}^{\mathrm{C}}$ \\
\hline \multicolumn{8}{|l|}{$9 / 7 / 83$} \\
\hline$\overline{1024}$ & - & 1.8 & 26.9 & 94.4 & 9.82 & - & - \\
\hline 1050 & - & 0.3 & 32.5 & $-\mathbf{5 3 . 7}$ & 9.91 & - & - \\
\hline 1115 & 1898 & 3.5 & 34.2 & 238.5 & 8.29 & - & - \\
\hline 1146 & 3136 & 4.7 & 35.3 & 257.9 & 8.74 & 97 & - \\
\hline 1234 & 5372 & 4.4 & 36.7 & 204.4 & 8.51 & - & - \\
\hline 1330 & 7982 & 4.1 & - & - & 8.43 & - & - \\
\hline 1430 & 10739 & 4.9 & - & 271.1 & 8.46 & - & - \\
\hline 1530 & 13545 & 4.2 & 39.6 & 259.5 & 8.45 & - & - \\
\hline 1630 & 16346 & 4.0 & 39.4 & 252.8 & 8.53 & 99 & - \\
\hline 1730 & 19173 & 3.6 & 40.6 & 239.6 & 8.67 & - & - \\
\hline 2130 & 30288 & 2.8 & 41.2 & 235.0 & 8.0 & - & - \\
\hline 2230 & 33100 & 3.3 & - & - & 8.13 & - & - \\
\hline 2330 & 35917 & 3.5 & 40.3 & 237.0 & 8.05 & - & - \\
\hline \multicolumn{8}{|l|}{$9 / 8 / 83$} \\
\hline$\overline{0030}$ & 38731 & 3.7 & 40.4 & 237.7 & 8.14 & - & - \\
\hline 0130 & 41535 & 3.3 & 40.8 & 244.0 & 8.13 & - & - \\
\hline 0230 & 44351 & 3.2 & - & - & 8.52 & - & - \\
\hline 0330 & 47189 & 2.8 & - & 245.8 & 8.68 & - & - \\
\hline 0430 & 50016 & 3.3 & 40.8 & 246.8 & 8.16 & 88 & - \\
\hline 0530 & 52833 & 3.0 & 41.6 & 230.8 & 8.15 & 96 & - \\
\hline 0630 & 55631 & 3.0 & 40.2 & 231.3 & 8.05 & - & - \\
\hline 0830 & 61187 & 3.0 & - & - & 8.57 & - & - \\
\hline 0930 & 63802 & 3.3 & 40.2 & 231.3 & 8.15 & 88 & - \\
\hline 1130 & 69466 & 2.8 & 40.8 & 234.5 & 8.65 & - & - \\
\hline 1200 & 71064 & 2.7 & 42.8 & 263.0 & 8.65 & 96.5 & 94.5 \\
\hline 1600 & 81372 & 2.8 & 44.0 & 254.3 & 8.68 & 118 & 98 \\
\hline 2050 & 96660 & 3.1 & 44.0 & 302.7 & 8.69 & 110 & 103 \\
\hline \multicolumn{8}{|l|}{$9 / 9 / 83$} \\
\hline 0025 & 107124 & 2.8 & 40.9 & 303.6 & 8.63 & 98 & 92 \\
\hline 0500 & 120426 & 2.8 & 42.1 & 249.0 & 8.64 & 97.5 & 97 \\
\hline 0833 & 130480 & 2.9 & 42.9 & 278.8 & 8.65 & 105 & 99 \\
\hline
\end{tabular}

a NHE = normal hydrogen electrode.

${ }^{\mathrm{b}} \mathrm{NF}=$ not filtered.

${ }^{\mathfrak{c}} \mathbf{F}=$ filtered.

Samples were taken at intervals for laboratory chemical analysis. Samples for radionuclide analysis were taken beginning at corrected flowmeter readings (gal) of 56,590 (188-L sample); 71,603 ( 19-L sample); 81,370, 96,660, 107,125, 120,425 , and 130,480 (all $\sim 2$-L samples); and 131,860 (200-L sample). All samples smelled of oil, and the final large-volume sample had a visible oil slick.

In the laboratory, the chemistry samples were $0.45-\mu \mathrm{m}$ filtered and analyzed for cations by inductively coupled plasma spectrometry (ICP), conductivity, and titration alkalinity; for carbonate by autoanalyzer; and for other anions by ion chromatography. Table 2-5 presents the results of these analyses. Analyses were carried out in two sets. Samples labeled \#1, \#2, etc., were analyzed first and the results circulated to RNM participants in an informal letter report; after discussion of possible trends in the data, additional analyses were carried out to fill out the series. The analytical precision may be estimated from the replicate analyses of sample \#6.

The small (2- and 19-L) samples were all field filtered through the same set of four $0.45-\mu \mathrm{m}$ Nuclepore filters. A 1-L aliquot of the 19-L sample was gamma counted in a Marinelli beaker, and all of the small samples were combined to yield a single 28 - $\mathrm{L}$ composite sample. The $200-\mathrm{L}$ sample collected at 131,860 gal was laboratory filtered $(0.45 \mu \mathrm{m})$ and evaporated, and the salts were gamma counted. The 188 - $\mathrm{L}$ sample taken at 56,590 gal and the $28-\mathrm{L}$ composite sample were both ultrafiltered; procedures and results are discussed in detail in Section 3.3. Table 2-5 summarizes the results of filtrate analyses for both the "standard" $(0.45-\mu \mathrm{m}$ filtered) and the ultrafiltered ( $\sim 0.006-$ $\mu \mathrm{m})$ samples. Table $2-6$ presents the total filterable activity $>0.45 \mu \mathrm{m}$ (prefilter plus $0.45-\mu \mathrm{m}$ filter) for each sample analyzed; ultrafiltration 
Table 2-5. Results of analyses of Cheshire samples.

\begin{tabular}{|c|c|c|c|c|c|c|c|c|c|c|c|c|c|}
\hline \multirow[b]{3}{*}{ Analysis } & & \multicolumn{12}{|c|}{ Ion chromatography (IC), autoanalyzer (AA), and other results } \\
\hline & & \multirow{2}{*}{$\begin{array}{c}3,136^{\mathrm{a}} \\
\# 1\end{array}$} & \multirow[b]{2}{*}{5860} & \multirow{2}{*}{$\begin{array}{c}13,545 \\
\# 2\end{array}$} & \multirow{2}{*}{\multicolumn{2}{|c|}{$\begin{array}{c}49,756 \\
\# 3\end{array}$}} & \multirow[b]{2}{*}{56,590} & \multirow{2}{*}{$\begin{array}{c}72,143 \\
\# 4\end{array}$} & \multirow{2}{*}{\multicolumn{2}{|c|}{$\begin{array}{c}107,124 \\
\# 5\end{array}$}} & \multirow[b]{2}{*}{120,376} & \multirow{2}{*}{$\begin{array}{c}130,480 \\
\# 6\end{array}$} & \multirow{2}{*}{$\begin{array}{c}130,480 \\
\# 6 \\
\end{array}$} \\
\hline & & & & & & & & & & & & & \\
\hline Fluoride & $(\mathrm{mg} / \mathrm{L})$ & 6.2 & 6.2 & 6.2 & 6.0 & 6.0 & 6.0 & 5.9 & 6.0 & 6.2 & 6.0 & 6.1 & 6.2 \\
\hline Chloride & $(\mathrm{mg} / \mathrm{L})$ & 14.6 & 14.3 & 13.4 & 13.6 & 13.3 & 13.0 & 13.4 & 13.7 & 15.2 & 13.3 & 13.4 & 14.4 \\
\hline Nitrate & $(\mathrm{mg} / \mathrm{L})$ & 1.0 & 1.5 & 0.3 & 1.4 & - & 2.0 & 0.4 & 1.6 & 2.4 & 1.2 & 2.0 & 2.4 \\
\hline Sulfate & $(\mathrm{mg} / \mathrm{L})$ & 34.35 & 33.9 & 33.5 & 32.8 & 32.8 & 33.4 & 32.8 & 33.8 & 35.2 & 33.7 & 34.4 & 35.8 \\
\hline Carbonate & $(\mathrm{meq} / \mathrm{L})$ & 2.91 & 2.72 & 2.60 & 2.57 & 2.52 & 2.55 & 254 & 254 & 284 & 257 & 252 & 287 \\
\hline Conductivity & $(\mathrm{mhos} / \mathrm{cm})$ & 403 & & 395 & & 380 & & & & & & & \\
\hline & $(\mu \mathrm{Ci} / \mathrm{mL})$ & 0.406 & & 0.402 & & 0.400 & & & & & & & \\
\hline \multirow[t]{2}{*}{ Alkalinity } & $(\mathrm{meq} / \mathrm{L})$ & 2.45 & & 2.33 & & 2.35 & & & & & & & \\
\hline & & \multicolumn{12}{|c|}{ ICP analysis - filtered and acidified } \\
\hline Element & Detection & 3136 & & 13,545 & & 49,756 & & 72,143 & & 107,124 & & 130,480 & 130,480 \\
\hline$(\mathrm{mg} / \mathrm{L})$ & limit & $\# 1$ & 5860 & \#2 & 19,173 & \#3 & 56,590 & $\# 4$ & 96,660 & $\# 5$ & 120,376 & \#6 & \#6 \\
\hline Aluminum & 0.020 & 1.11 & 1.36 & 0.369 & 1.45 & 0.261 & 1.80 & 0.373 & 1.49 & 2.14 & 2.16 & 1.83 & 2.43 \\
\hline Boron & 0.020 & 0.112 & 0.114 & 0.097 & 0.100 & 0.107 & 0.112 & 0.100 & 0.095 & 0.102 & 0.107 & 0.100 & 0.112 \\
\hline Cadmium & 0.003 & 0.001 & 0.000 & 0 & 0 & 0.001 & 0.002 & 0.000 & 0.001 & 0 & 0.00 & 0.00 & 0.002 \\
\hline Cobalt & 0.003 & 0.001 & 0 & 0 & 0 & 0 & 0 & 0 & 0 & 0 & 0 & 0.001 & 0 \\
\hline Copper & 0.003 & 0 & 0 & 0 & 0 & 0.002 & 0 & 0.0 & 0 & 0 & 0 & & 0 \\
\hline Iron & 0.004 & 0.144 & 0.291 & 0.255 & 0.238 & 0.055 & 0.166 & 0.298 & 0.161 & 0.222 & 0.275 & 0.226 & 0.362 \\
\hline Lithium & 0.001 & 0.255 & 0.189 & 0.174 & 0.177 & 0.175 & 0.162 & 0.161 & 0.154 & 0.169 & 0.169 & 0.163 & 0.159 \\
\hline Manganese & 0.0005 & 0.011 & 0.022 & 0.036 & 0.087 & 0.073 & 0.096 & 0.041 & 0.107 & 0.056 & 0.126 & 0.105 & 0.110 \\
\hline Molybdenum & 0.004 & 0.030 & 0.024 & 0.021 & 0.021 & 0.018 & 0.017 & 0.019 & 0.020 & 0.019 & 0.022 & 0.021 & 0.020 \\
\hline Nickel & 0.008 & 0.022 & 0.022 & 0.044 & 0.006 & 0.001 & 0.004 & 0.006 & 0.004 & 0.0 & 0.003 & 0.001 & 0.006 \\
\hline Phosphorus & 0.124 & 0.162 & 0.087 & 0.136 & 0.139 & 0.121 & 0.098 & 0.143 & 0.095 & 0.113 & 0.136 & 0.087 & 0.152 \\
\hline Lead & 0.016 & 0.016 & 0.028 & 0.020 & 0.031 & 0.011 & 0.017 & 0.020 & 0.027 & 0.017 & 0.020 & 0.024 & 0.027 \\
\hline Selenium & 0.100 & 0.047 & 0.065 & 0.061 & 0.042 & 0.057 & 0.055 & 0.063 & 0.042 & 0.048 & 0.055 & 0.054 & 0.057 \\
\hline Silicon & 0.008 & 30.5 & 31.0 & 28.0 & 31.3 & 27.8 & 31.7 & 28.1 & 31.0 & 32.9 & 33.2 & 32.0 & 34.1 \\
\hline Strontium & 0.012 & 0.070 & 0.031 & 0.014 & 0.017 & 0 & 0.006 & 0.005 & 0.007 & 0.0 & 0.0 & 0.003 & 0.006 \\
\hline Uranium & 0.084 & & & & & & & & & & & & \\
\hline Vanadium & 0.003 & 0.003 & 0.003 & 0.001 & 0.001 & 0.000 & 0.001 & 0.002 & 0.002 & 0 & 0 & 0.003 & 0.002 \\
\hline Zinc & 0.008 & 0.018 & 0.015 & 0.013 & 0.029 & 0.019 & 0.010 & 0.010 & 0.006 & 0.006 & 0.006 & 0.005 & 0.006 \\
\hline Calcium & 0.020 & 8.64 & 4.63 & 3.17 & 3.17 & 2.09 & 2.03 & 1.71 & 1.64 & 1.77 & 1.73 & 1.59 & 1.57 \\
\hline Potassium & 0.536 & 4.81 & 2.64 & 1.81 & 3.20 & 2.32 & 2.73 & 1.79 & 2.88 & 3.06 & 3.24 & 2.86 & 3.36 \\
\hline Magnesium & 0.004 & 0.168 & 0.090 & 0.355 & 0.051 & 0.039 & 0.044 & 0.631 & 0.034 & 0.092 & 0.152 & 0.077 & 0.253 \\
\hline Sodium & 0.024 & 85.1 & 74.8 & 72.5 & 80.9 & 80.5 & 72.2 & 71.8 & 69.7 & 81.3 & 81.9 & 73.9 & 72.2 \\
\hline
\end{tabular}

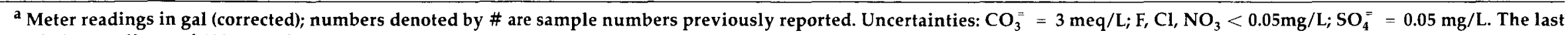
sample is a replicate of $130,480 \mathrm{gal}$. 
Table 2-6. Cheshire sample radionuclide inventory: filtrate samples calculated to day 253.5 (1983). Units are $\mathrm{dpm} / \mathrm{L}( \pm 1 \mathrm{std} \mathrm{dev} \%)$.

\begin{tabular}{|c|c|c|c|c|}
\hline \multirow[b]{2}{*}{ Nuclide } & \multicolumn{2}{|c|}{ Field aliquot $^{a}$} & \multirow{2}{*}{$\begin{array}{c}\frac{\text { Barrel }(131,860)^{b}}{0.45-\mu \mathrm{m}} \\
200 \mathrm{~L}\end{array}$} & \multirow{2}{*}{$\begin{array}{c}\text { Barrel }(56,790)^{\mathrm{b}} \\
0.006-\mu \mathrm{m} \\
188 \mathrm{~L}\end{array}$} \\
\hline & $\begin{array}{c}0.45-\mu \mathrm{m} \\
28 \mathrm{~L}\end{array}$ & $\begin{array}{c}0.006-\mu \mathrm{m} \\
28 \mathrm{~L}\end{array}$ & & \\
\hline${ }^{22} \mathrm{Na}$ & $\begin{array}{l}2.80 \\
(55 \%)\end{array}$ & $\begin{array}{l}2.86 \\
(26 \%)\end{array}$ & $\begin{array}{l}2.67 \\
(8.7 \%)\end{array}$ & $\begin{array}{l}2.54 \\
(20.8 \%)\end{array}$ \\
\hline${ }^{40} \mathrm{~K}$ & $N^{c}{ }^{c}$ & NL & $\begin{array}{l}8.45 \\
(6.8 \%)\end{array}$ & $\begin{array}{l}3.87 \\
(29.6 \%)\end{array}$ \\
\hline $\begin{array}{l}{ }^{54} \mathrm{Mn} \\
{ }^{60} \mathrm{Co}\end{array}$ & $\begin{array}{l}\text { NL } \\
\text { NL }\end{array}$ & $\begin{array}{l}\text { NL } \\
\text { NL }\end{array}$ & $\begin{array}{l}0.38 \\
<0.1\end{array}$ & $<0.17$ \\
\hline${ }^{85} \mathrm{Kr}$ & $\begin{array}{l}35,100 \\
(7 \%)\end{array}$ & NL & NL & NL \\
\hline $\begin{array}{l}{ }^{106} \mathrm{Ru} \\
(622 \mathrm{keV})\end{array}$ & NL & NL & $\begin{array}{l}156.9 \\
(1.7 \%)\end{array}$ & $<7.7$ \\
\hline${ }^{125} \mathrm{Sb}$ & $\begin{array}{l}1858 \\
(4 \%)\end{array}$ & $\begin{array}{l}1709 \\
(4 \%)\end{array}$ & $\begin{array}{l}2067 \\
(0.6 \%)\end{array}$ & $\begin{array}{l}1703 \\
(0.6 \%)\end{array}$ \\
\hline${ }^{134} \mathrm{Cs}$ & $\begin{array}{l}4.26 \\
(2 \%)\end{array}$ & $\begin{array}{l}2.44 \\
(22 \%)\end{array}$ & $\begin{array}{l}3.83 \\
(5.2 \%)\end{array}$ & $\begin{array}{l}2.77 \\
(16 \%)\end{array}$ \\
\hline${ }^{137} \mathrm{Cs}$ & $\begin{array}{l}4351 \\
(2 \%)\end{array}$ & $\begin{array}{l}3596 \\
(2.05 \%)\end{array}$ & $\begin{array}{l}5135 \\
(0.7 \%)\end{array}$ & $\begin{array}{l}3238 \\
(1.7 \%)\end{array}$ \\
\hline${ }^{144} \mathrm{Ce}$ & NL & NL & $\begin{array}{l}25.82 \\
(6.1 \%)\end{array}$ & $<5.6$ \\
\hline${ }^{152} \mathrm{Eu}$ & NL & NL & $\begin{array}{l}14.47 \\
(2.1 \%)\end{array}$ & $<0.81$ \\
\hline${ }^{154} \mathrm{Eu}$ & NL & NL & $\begin{array}{l}14.47 \\
(2.1 \%)\end{array}$ & $<0.85$ \\
\hline${ }^{155} \mathrm{Eu}$ & NL & NL & $\begin{array}{l}18.91 \\
(2.5 \%)\end{array}$ & $<2.9$ \\
\hline
\end{tabular}

a Field aliquot = composite of samples; see text for volumes.

b Corrected meter reading (gal) at time of sampling.

${ }^{c} \mathrm{NL}=$ not detected, no limit calculated.

retentate activities are presented and discussed in Section 3.3. Table $2-7$ presents the total activity inventory for each sample; this is the sum of the activities of all filters, the ultrafilter retentate (if any), and the final filtrate. All activities are normalized to $\mathrm{dpm} / \mathrm{L}$. The uncertainties reported are based on counting statistics only and are unrealistically precise; as discussed in Appendix A, actual experimental uncertainties are probably in the range of $\pm 20 \%$.

\subsubsection{Discussion}

In both the early and the more recent sampling, there has been considerable concern about the degree to which the samples obtained actually represent formation water unaffected by well construction or conditioning. Chemical analyses were seen as one way to evaluate sample quality, especially because all drilling fluids had been tagged with lithium salts $(\sim 20 \mathrm{ppm} \mathrm{Li})$.

Figure 2-2 plots lithium concentrations as a function of volume pumped. There appears to be a calibration shift between the two sets of analyses, but both sets indicate an initial drop followed by stabilization after a total volume of
$50,000-70,000$ gal pumped. The pattern is seen even more clearly for calcium (possibly influenced by casing cement) in Fig. 2-3, which indicates stable concentrations after 70,000 gal. Table 2-3 shows that $\mathrm{pH}$ results show a similar pattern, stabilizing from 69,206 gal onward. The $\mathrm{Cl}^{-}$and $\mathrm{CO}_{3}^{-}$values in Table 2-4 show an initial decrease in the first two samples. Tritium values were stable throughout, as were most other chemical constituents.

Table 2-7 shows that the total activity (filters plus filtrates) inventories of the two large-volume samples are in reasonable agreement, indicating that there was no major shift in radionuclide content between the two sampling times. Values for the 28-L composite sample are similar but somewhat higher; Tables 2-6 and 2-7 show that for most of the nuclides the additional activity is apparently associated with the particulate phase (see the discussion in Section 3.3.).

Solution activity is dominated by ${ }^{137} \mathrm{Cs}$ and ${ }^{125} \mathrm{Sb}$; nearly all of the ${ }^{125} \mathrm{Sb}$ and more than half of the ${ }^{137} \mathrm{Cs}$ (and ${ }^{134} \mathrm{Cs}$ ) is not filterable even by ultrafiltration. There is good agreement between the two $0.45-\mu \mathrm{m}$ filtrates, and also between the two 
Table 2-7. Cheshire sample radionuclide inventory: total filter + filtrate inventory calculated to day 253.5 (1983). Units are $\mathrm{dpm} / \mathrm{L}( \pm 1 \mathrm{std} \mathrm{dev} \%)$.

\begin{tabular}{|c|c|c|c|c|c|c|}
\hline \multirow[b]{2}{*}{ Nuclide } & \multicolumn{2}{|c|}{ Field aliquot ${ }^{a}$} & \multicolumn{2}{|c|}{ Barrel $(131,860 \mathrm{gal})$} & \multicolumn{2}{|c|}{ Barrel $(56,330$ gal $)$} \\
\hline & $\begin{array}{c}\text { Composite } \\
\text { filter } \\
28 \mathrm{~L}\end{array}$ & $\begin{array}{c}\text { Total } \\
\text { filter }+ \\
\text { filtrate }\end{array}$ & $\begin{array}{l}\text { Composite } \\
\text { filter } \\
200 \mathrm{~L}\end{array}$ & $\begin{array}{c}\text { Total } \\
\text { filter }+ \\
\text { filtrate }\end{array}$ & $\begin{array}{c}\text { Composite } \\
\text { filter } \\
188 \mathrm{~L}\end{array}$ & $\begin{array}{l}\text { Total } \\
\text { filter }+ \\
\text { filtrate }\end{array}$ \\
\hline${ }^{22} \mathrm{Na}$ & $\begin{array}{l}1.12 \\
(30.6 \%)\end{array}$ & 3.9 & $\begin{array}{l}0.32 \\
(38 \%)\end{array}$ & 2.99 & $<0.10$ & 2.54 \\
\hline${ }^{40} \mathrm{~K}$ & $\begin{array}{l}0.8 \\
(32.6 \%)\end{array}$ & 0.8 & $\begin{array}{l}3.14 \\
(11.6 \%)\end{array}$ & 11.59 & $\begin{array}{l}3.71 \\
(19.4 \%)\end{array}$ & 7.58 \\
\hline${ }^{54} \mathrm{Mn}$ & $\begin{array}{l}0.87 \\
(16 \%)\end{array}$ & 0.87 & $\begin{array}{l}0.25 \\
(31.4 \%)\end{array}$ & 0.63 & $\begin{array}{l}0.56 \\
(57 \%)\end{array}$ & 0.56 \\
\hline${ }^{60} \mathrm{Co}$ & $\mathbf{N L}^{\mathbf{b}}$ & 7.32 & $\begin{array}{l}2.06 \\
(4.3 \%)\end{array}$ & 5.38 & $\begin{array}{l}4.57 \\
(3.0 \%)\end{array}$ & 4.57 \\
\hline $\begin{array}{l}{ }^{106} \mathrm{Ru} \\
(622 \mathrm{keV})\end{array}$ & $\begin{array}{l}222 \\
(1.0 \%)\end{array}$ & 222 & $\begin{array}{l}40.8 \\
(4.9 \%)\end{array}$ & 197.7 & $\begin{array}{l}150.6 \\
(19.0 \%)\end{array}$ & 150.6 \\
\hline${ }^{125} \mathrm{Sb}$ & $\begin{array}{l}79.1 \\
(1.3 \%)\end{array}$ & 1937 & $\begin{array}{l}17.1 \\
(3.4 \%)\end{array}$ & 2084 & $\begin{array}{l}91.2 \\
(2.6 \%)\end{array}$ & 1794 \\
\hline${ }^{134} \mathrm{Cs}$ & $\begin{array}{l}1.94 \\
(8.0 \%)\end{array}$ & 6.2 & $\begin{array}{l}0.89 \\
(3.9 \%)\end{array}$ & 4.7 & $\begin{array}{l}1.57 \\
(20.5 \%)\end{array}$ & 4.34 \\
\hline${ }^{137} \mathrm{Cs}$ & $\begin{array}{l}3651 \\
(1.0 \%)\end{array}$ & 8002 & $\begin{array}{l}1422.6 \\
(0.9 \%)\end{array}$ & 6557 & $\begin{array}{l}2699 \\
(1.1 \%)\end{array}$ & 5937 \\
\hline${ }^{144} \mathrm{Ce}$ & $\begin{array}{l}48.1 \\
(4.7 \%)\end{array}$ & 48.1 & $\begin{array}{l}7.82 \\
(10.6 \%)\end{array}$ & 33.6 & $\begin{array}{l}26.51 \\
(20 \%)\end{array}$ & 26.51 \\
\hline${ }^{152} \mathrm{Eu}$ & $\begin{array}{l}23.8 \\
(1.9 \%)\end{array}$ & 23.8 & $\begin{array}{l}4.01 \\
(2.5 \%)\end{array}$ & 18.0 & $\begin{array}{l}14.41 \\
(19 \%)\end{array}$ & 14.41 \\
\hline${ }^{154} \mathrm{Eu}$ & $\begin{array}{l}30.8 \\
(1.7 \%)\end{array}$ & 30.8 & $\begin{array}{l}5.4 \\
(2.2 \%)\end{array}$ & 19.87 & $\begin{array}{l}19.81 \\
(10.8 \%)\end{array}$ & 19.81 \\
\hline${ }^{155} \mathrm{Eu}$ & $\begin{array}{l}56.0 \\
(5.2 \%)\end{array}$ & 56.0 & $\begin{array}{l}9.8 \\
(2.9 \%)\end{array}$ & 28.7 & $\begin{array}{l}30.37 \\
(5.4 \%)\end{array}$ & 30.37 \\
\hline${ }^{241} \mathrm{Am}$ & $\begin{array}{l}5.48 \\
(55.1 \%)\end{array}$ & 5.48 & NL & 0.11 & $\begin{array}{l}2.76 \\
(50.8 \%)\end{array}$ & 2.76 \\
\hline
\end{tabular}

${ }^{\text {a }}$ Field aliquot $=$ composite of samples, see text for volumes. For the field aliquot and the 56,330 -gal barrel sample, the composite filter value includes both standard filters and the ultrafilter $(0.006-\mu \mathrm{m})$ retentate.

b $\mathrm{NL}=$ not detected, no limit calculated.

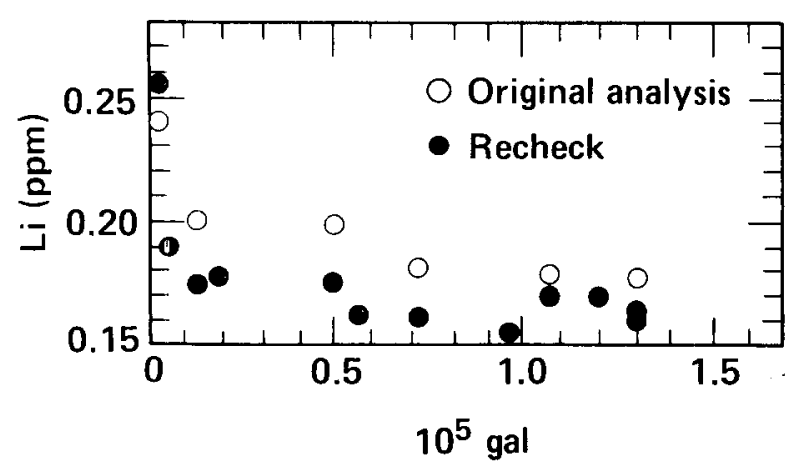

Figure 2-2. U20n (Cheshire) lithium vs volume pumped.

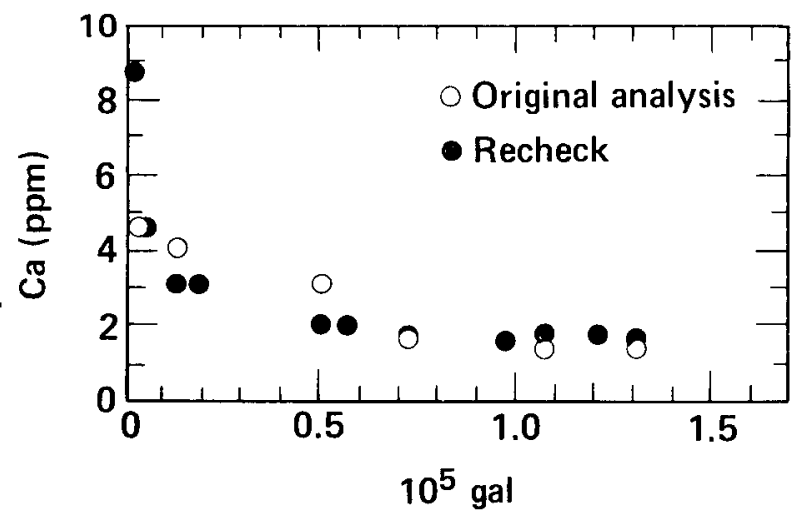

Figure 2-3. U20n (Cheshire) calcium vs volume pumped. 
$0.006-\mu \mathrm{m}$ ultrafiltrates. This agreement, together with the similarities in large-volume total activity inventories discussed above, suggests that there is no evidence for any consistent relationship between sample activity and volume pumped. It should also be noted that there is good agreement on the salt contents in the $<0.45-\mu \mathrm{m}$ size range for the two large-volume samples. The 200-L filtrate yielded $63.84 \mathrm{~g}$ when dried, or $0.32 \mathrm{~g} / \mathrm{L}$; the 188 - L ultrafiltrate yielded $48.09 \mathrm{~g}$ and the $3-\mathrm{L}$ retentate produced $11.18 \mathrm{~g}$, for a combined total of $0.31 \mathrm{~g} / \mathrm{L}$. The retentate/ultrafiltrate salt concentration ratio is about 15 , which is similar to but slightly higher than the chemical concentration ratios reported in Section 3.3.

The observations concerning the smaller but readily measurable concentrations of ${ }^{54} \mathrm{Mn},{ }^{60} \mathrm{Co}$, ${ }^{106} \mathrm{Ru},{ }^{144} \mathrm{Ce}$, and the europium isotopes are of particular interest. In the conventionally treated sample $(0.45-\mu \mathrm{m}$ filter), significant concentrations are seen in the filtrate. The data of Table 2-6 show, however, that these nuclides are quantitatively removed by ultrafiltration in both of the other samples analyzed (although quantitative upper limits are not reported for the composite sample ultrafiltrate, they are well below the concentration levels reported for the $0.45-\mu \mathrm{m}$ filtrate). Because of the good agreement between the total activity inventories of the two large-volume samples, it seems safe to treat these samples as replicates, and the results therefore clearly imply that most of the transition and lanthanide element radionuclides are associated with particles in the 0.006 - to $0.45-\mu \mathrm{m}$ size range.

These results are of considerable importance to calculations of distribution and retardation coefficients based on field data, and they further emphasize the need for study of the role of submicron particles in radionuclide transport processes.

Further analyses and filtration studies are planned for the U20n samples collected during 1984.

\subsection{Cambric (U5e)}

\section{(Contributors: J. Rego and R. W. Buddemeier)}

The RNM experiments associated with the Cambric site have been extensively documented both in technical reports ${ }^{6-14}$ and in publications in the scientific literature. ${ }^{15-20}$ This report will be limited to the presentation of basic background material and previously unpublished LLNL data. Section 4 of this report describes a new experimental initiative based on the Cambric pumping experiment.
The Cambric (U5்) device was detonated on May 14, 1965, with a yield of $0.75 \mathrm{kt}$. The working point was at a depth of $294 \mathrm{~m}$ in alluvium; the alluvium-tuff contact was at a depth of $690 \mathrm{~m}$ and the preshot water table was $73 \mathrm{~m}$ above the working point. For a variety of reasons (yield, location, and aquifer type), the Cambric site was judged to be ideal for an active RNM experiment, and in 1974 two experimental holes were drilled.

A reentry hole, RNM-1, was slant drilled through the cavity on June 20,1974, with core, water, and gas samples taken at selected intervals. ${ }^{10,18,19}$ After completion of the initial sampling, the packers between the two uppermost zones were drilled out and a pump was installed just above the cavity to permit periodic resampling of the source. Satellite well RNM-2S was drilled in April 1974. It was located $91 \mathrm{~m}$ from the Cambric cavity, was drilled to a total depth of $340 \mathrm{~m}$, and was perforated at 340 and $316 \mathrm{~m}$. A pump was installed at $300 \mathrm{~m}$. Figure 2-4 shows the Cambric site vertical cross section. In an effort to induce radionuclide migration by imposing an artificial hydraulic gradient on the system, continuous pumping of RNM-2S at a rate of approximately $1 \mathrm{~m}^{3} /$ min was begun in October 1975 . In October 1977, a larger pump was installed and pumping was resumed at a rate of $2.3 \mathrm{~m}^{3} / \mathrm{min}$. Tritium breakthrough was observed in RNM-2S in December 1977. The tritium concentration in the RNM-2S effluent reached a maximum in July 1980 and has been slowly decreasing since then.

Numerous samples have been taken by LANL (see cited references) and LLNL over the course of the pumping experiment. Tables 2-8 and 2-9 give the histories of the RNM-1 and RNM-2S holes. Table 2-10 presents the results of LLNL analyses of large-volume water samples from RNM-1; RNM-2S results are given in Table 2-11.

The Cambric source term and the significance of changes in RNM-1 activities have been discussed in detail in various LANL publications; these observations will not be repeated here. In addition to tritium, LANL has measured ${ }^{85} \mathrm{Kr}$ (which apparently moves conservatively with the tritium), ${ }^{36} \mathrm{Cl}$, and ${ }^{129} \mathrm{I}$ in RNM-2S samples. The only other nuclide detected in RNM-2S samples has been ${ }^{106} \mathrm{Ru}^{15}$; the low levels of ${ }^{137} \mathrm{Cs}$ reported in Table 2-11 are of the magnitude normally associated with ubiquitous surface contamination and are not considered significant (see Section 2.1.2). Although the actual ${ }^{106} \mathrm{Ru}$ activities observed are quite low because of the short half-life, the data suggest that the ${ }^{106} \mathrm{Ru}$ activity correlates with the tritium activity, indicating conservative behavior. 


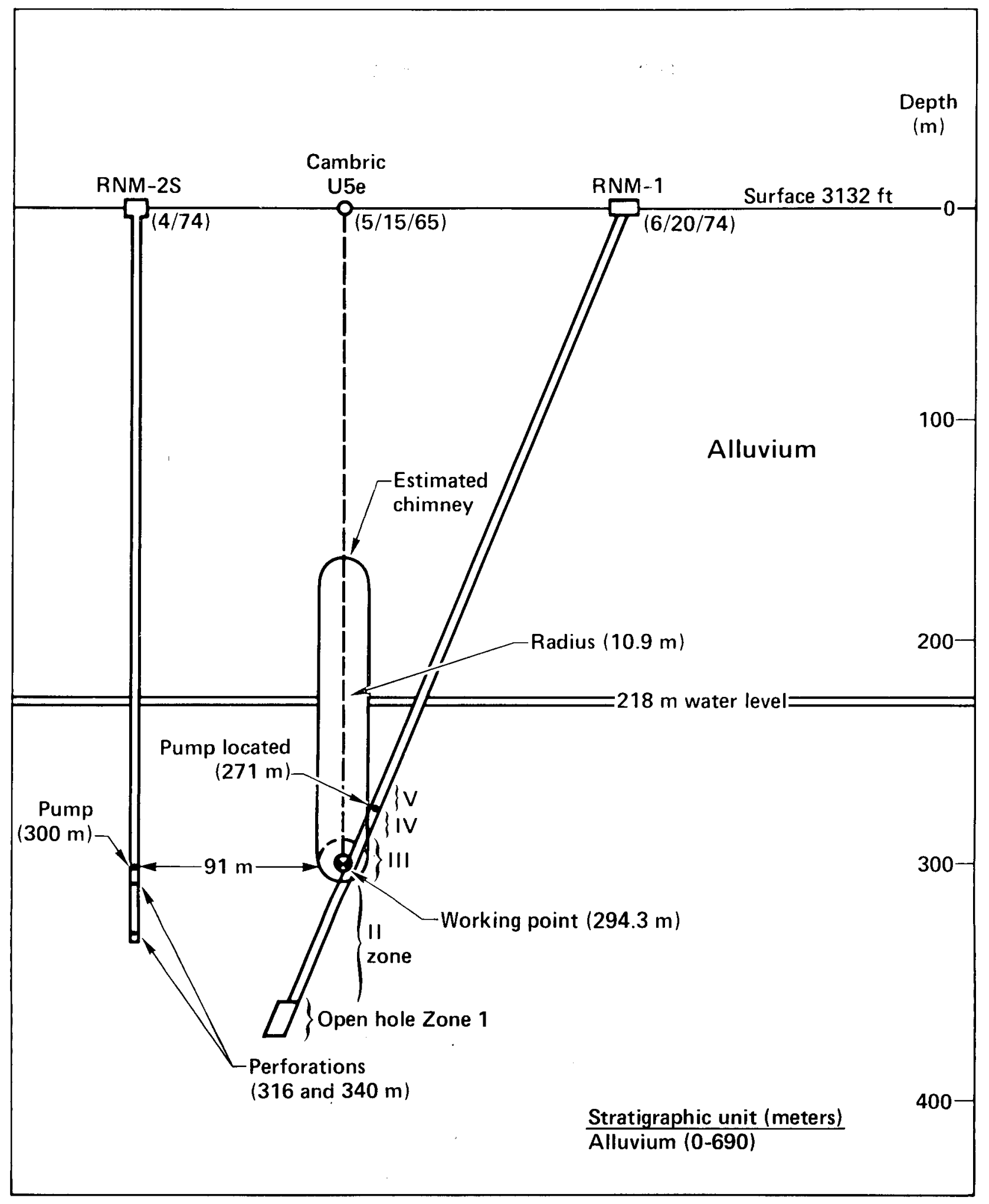

Figure 2-4. Cambric site cross section. 
Table 2-8. Cambric (RNM-1) chronology, and dates of LLNL sampling.

\begin{tabular}{|c|c|}
\hline Date & Event \\
\hline $5 / 14 / 65$ & Detonation; yield $75 \mathrm{kt}$, working point $294.3 \mathrm{~m}$. \\
\hline $6 / 20 / 74$ & RNM-1 (cavity well) drilled; total slant depth $397 \mathrm{~m}$, total depth $370 \mathrm{~m}$, cored. \\
\hline $6 / 74-8 / 75$ & Five hydrologic zones in the well isolated and sampled. \\
\hline $10 / 4 / 77$ & $\begin{array}{l}\text { Pump installed at } 270.7 \mathrm{~m} \mathrm{MSD.} \mathrm{(Ref.} \mathrm{Hoffman,} \mathrm{Memo} \mathrm{10/11/77,} \mathrm{LANL.)} \\
\text { First reentry, pumped } 56.8 \mathrm{~m}^{3} \text { from zones IV and V. }\end{array}$ \\
\hline $11 / 30 / 77$ & Second reentry, LLNL and LANL samples taken. \\
\hline $9 / 4 / 79$ & LLNL sampling. \\
\hline $10 / 5 / 81$ & LLNL sampling. \\
\hline $4 / 1 / 82$ & LLNL sampling. \\
\hline \multicolumn{2}{|c|}{$\begin{array}{l}\text { D-series samples (Zone III) } 1 \text { to } 17 \text { ranged from } 7.6 \text { to } 8.5 \times 10^{6} \mathrm{dpm} / \mathrm{L} \text {. } \\
\text { E-series samples (Zone IV) } 1.8 \times 10^{5} \mathrm{dpm} / \mathrm{L} ;{ }^{137} \mathrm{Cs} 735 \mathrm{dpm} / \mathrm{L} \text {. } \\
\text { F-series samples (Zone V) } 6.2 \times 10^{4} \mathrm{dpm} / \mathrm{L} ;{ }^{137} \mathrm{Cs} 780 \text { to } 66 \mathrm{dpm} / \mathrm{L} \text {. }\end{array}$} \\
\hline Date & Event \\
\hline $4 / 74$ & RNM-2S drilled, $91 \mathrm{~m}$ from cavity, total depth $340 \mathrm{~m}$. \\
\hline $10 / 75$ & $\begin{array}{l}\text { Pump installed at } 300 \mathrm{~m} \text {. Pumping commenced at a rate of } 0.95-1.14 \mathrm{~m}^{3} / \mathrm{min} \text {. } \\
\text { Pumped continuously except for brief periods for repair and maintenance. }\end{array}$ \\
\hline $10 / 77$ & Pump replaced; pumping resumed at a rate of $2.27 \mathrm{~m}^{3} / \mathrm{min}$. Sampling continued. \\
\hline $12 / 27 / 77$ & ${ }^{3} \mathrm{H}$ breakthrough at total volume $1.44 \times 10^{6} \mathrm{~m}^{3}$ pumped. \\
\hline $11 / 29 / 78$ & LLNL large-volume, low-level sampling. \\
\hline $3 / 14 / 79$ & LLNL large-volume, low-level sampling. \\
\hline $8 / 29 / 79$ & LLNL large-volume, low-level sampling. \\
\hline $11 / 10 / 82$ & LLNL large-volume, low-level sampling. \\
\hline $4 / 19 / 84$ & Field measurements and LLNL large-volume low-level sampling. \\
\hline
\end{tabular}

This result appears to be at odds with observation of the Bilby chimney showing that ${ }^{106} \mathrm{Ru}$ decreased much more rapidly than tritium activity between 1977 and 1981 (see Table 2-21, Section 2.5). This apparent contradiction may be the result of a redox equilibrium that permits ruthenium to exist either as the mobile anionic form $\mathrm{RuO}_{4}^{-}$or as the more readily sorbed cationic species, depending on the $\mathrm{Eh} / \mathrm{pH}$ conditions in the ground-water system. The chemical and geochemical characteristics of ruthenium are discussed in more detail in Section 5.

One unresolved issue relating to the Cambric pumping experiment is the question of whether the pumped effluent, which is discharged into an unlined ditch near the wellhead, may have recharged the water table over the course of the experiment. If this has occurred, the possibility that RNM-2S pumping may be sampling some fraction of recycled water will have to be considered; this could complicate quantitative modeling of the transport of radionuclides from RNM-1 to RNM-2S. This possibility, which was one of the motivations for initiating the Cambric plume study, is discussed in Section 4.

\subsection{Nash (UE2ce)}

\section{(Contributors: R. W. Buddemeier and J. Rego)}

The Nash Event was detonated on January 19, 1967 with an announced yield in the 20- to 200-kt range. The working point was at a depth of $367.5 \mathrm{~m}$. Chimney collapse occurred shortly after detonation.

Satellite well UE2ce was drilled on January 25, 1977; the target location was $183 \mathrm{~m}$ due south of U2ce. Pawloski ${ }^{21}$ reports the location as $55.6 \mathrm{~m}$ south of U2ce, but this is almost certainly 
Table 2-10. Analysis of Cambric cavity well RNM-1 calculated to day 135 (1979).

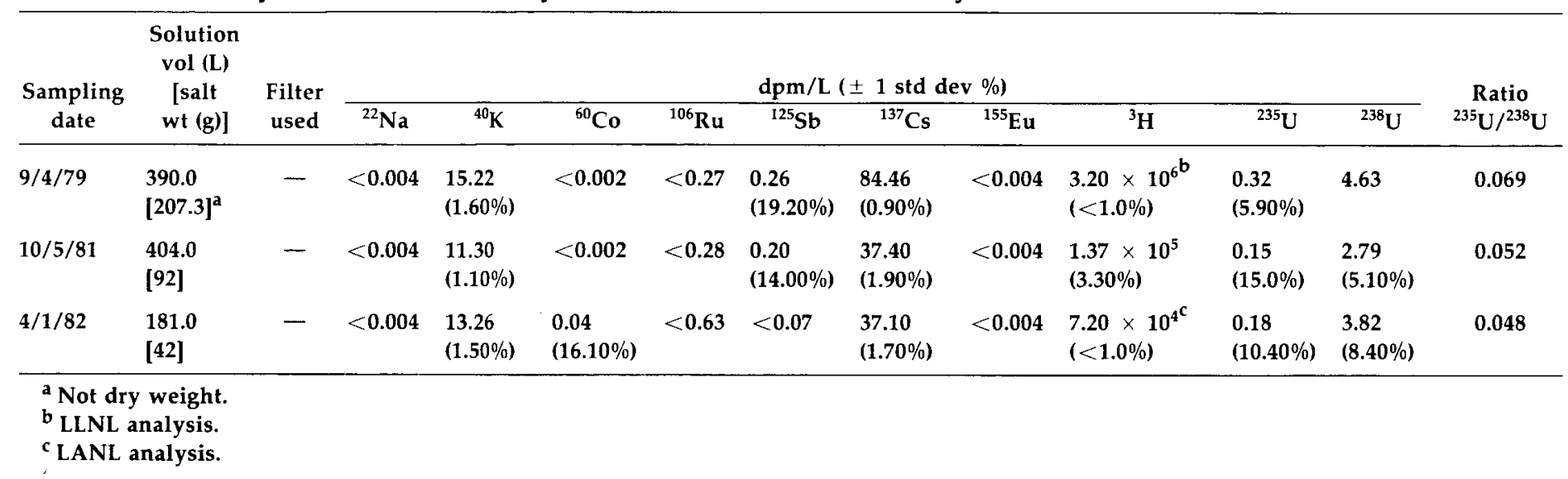

Table 2-11. Analysis of Cambric satellite well (RNM-2S) calculated to day 135 (1979).

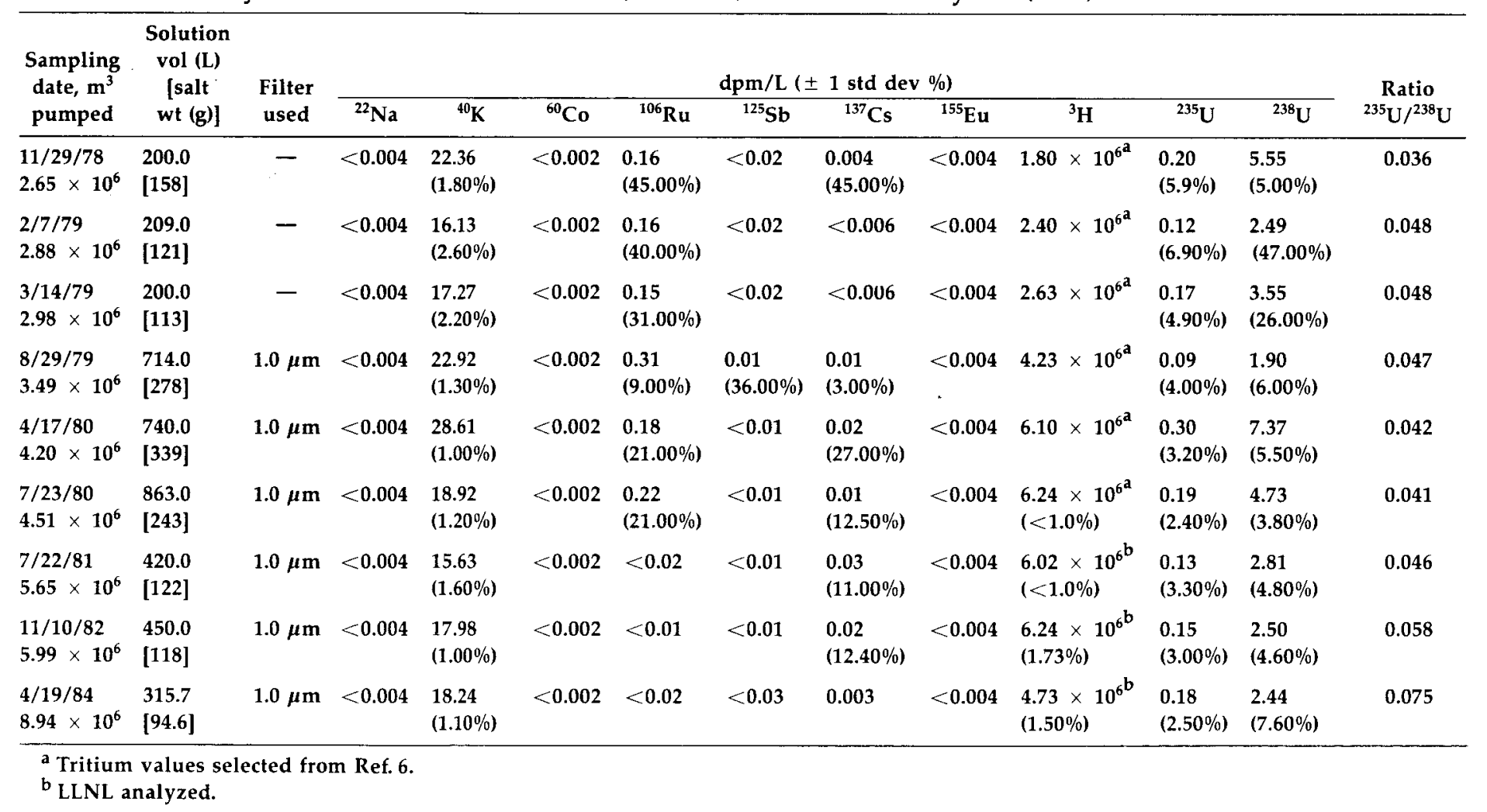


in error; we have paced off the distance from UE2ce to the Nash crater rim as 100 yards, and we believe that the hole is indeed located approximately $600 \mathrm{ft}$ south of U2ce ground zero. ${ }^{22}$ The well was drilled to a total depth of $503 \mathrm{~m}$, cased to $495 \mathrm{~m}$, cemented at $422 \mathrm{~m}$, and perforated in the 422- to 495 - $\mathrm{m}$ interval. ${ }^{21}$

Based on cores and geophysical logs, the site stratigraphy is alluvium from the surface to $126 \mathrm{~m}$, tuff from 126 to $340 \mathrm{~m}$, and Paleozoic carbonates below $340 \mathrm{~m}$. Measurements of depth to water in UE2ce in 1977 yielded values ranging from 426 to $434 \mathrm{~m}^{21}$ suggesting that the equilibrium water table is probably below the cavity. The most probable direction of natural ground-water flow at the Nash site is southeastward, but no rigorous local determinations of gradient have been made and differing interpretations of the regional data yield flow directions ranging from due east to due south. $^{23}$

Area 2 in the general vicinity of UE2ce is a heavily used section of NTS; several shots have been fired within a $1-\mathrm{km}$ radius of the Nash Event, and a substantial number within a slightly larger radius. This suggests the possibility that the hydraulic effects of other detonations, including water table variations and temporary changes in the rate and direction of local ground-water flow, may need to be considered in assessing the hydrology of the Nash site.

Based on the foregoing, we can see that the detonation occurred in the upper Paleozoic, that the bottom of the cavity probably does not extend into the normally saturated zone, and that the satellite well (assuming integrity of casing and seal) produces water exclusively from the carbonate aquifer. Figure 2-5 shows the Nash site vertical cross section.

\subsubsection{Sampling and Analysis}

Pumping and sampling have been conducted intermittently since 1977; Table $2-12$ is a chronologic summary of activities. Figure 2-6 summarizes tritium activities from all sources (LANL, REECo, and LLNL) as a function of total volume pumped, with the dates and major events noted. Large-volume samples were collected by LLNL on March 15, 1978, October 9, 1980, February 22, 1982, August 9, 1982, August 10, 1983 and April 18-19, 1984. All samples were evaporated and the salts counted by low-level gamma spectroscopy. The 1984 sample was also filtered and the filter analyzed. Table 2-13 presents the results of these determinations, with tritium results added for completeness. The apparent europium results from the GAMANAL spectral analysis are almost

Table 2-12. Nash satellite well (UE2ce) chronology.

\begin{tabular}{ll}
\hline \multicolumn{1}{c}{ Date } & \multicolumn{1}{c}{ Chronology } \\
\hline $1 / 19 / 67$ & Detonation; yield range $20-200 \mathrm{kt}$; working point $367.6 \mathrm{~m}$. \\
$1 / 25 / 77$ & Satellite well, UE2ce, drilled and cored; perforated at $422-495 \mathrm{~m}$. Water level $434 \mathrm{~m}$. \\
$4 / 12 / 77$ & Well released for RNM studies. \\
$5 / 18 / 77$ & Pump installed at $486.5 \mathrm{~m}$. Water level $426.1 \mathrm{~m}$. \\
$5 / 19-20 / 77$ & Pump tests and sampling at intervals. Water level $432.2 \mathrm{~m}$. \\
$5 / 21 / 77-8 / 10 / 77$ & Pumping intervals as directed. \\
$11 / 15 / 77$ & Start of continuous pumping. \\
$12 / 21 / 77$ & Pump stopped. Excessive drawdown. \\
$2 / 27 / 78$ & Start of continous pumping. \\
$3 / 15 / 78$ & LLNL large-volume sampling. \\
$3 / 24 / 78$ & Pump shut down after excessive drawdown coinciding with NTS event. \\
$8 / 28 / 80$ & Pump replaced. Rate of $46 \mathrm{~L} / \mathrm{min} ;$ pump intake at $475.4 \mathrm{~m}$. Water level $434 \mathrm{~m}$. \\
$2 / 24 / 82$ & LLNL collection; throttled back to $23 \mathrm{~L} / \mathrm{min}$. Start of continuous pumping. \\
$7 / 9 / 82$ & LLNL large-volume collection. \\
$8 / 10 / 83$ & USGS collection for LLNL. \\
$4 / 18 / 84$ & Field measurements and large-volume collection. \\
\hline
\end{tabular}




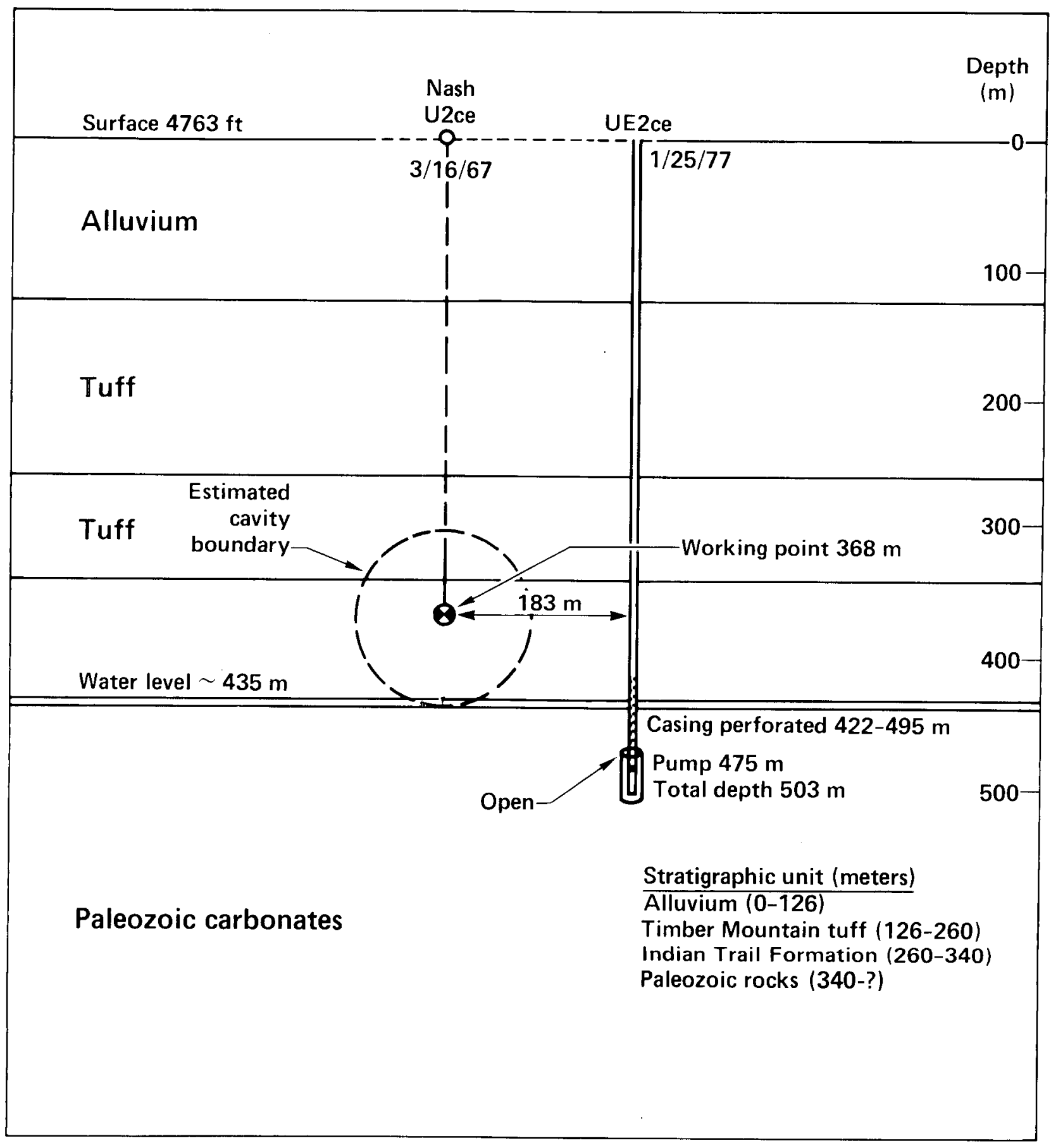

Figure 2-5. Nash site cross section.

certainly spurious, probably caused by thorium interferences (see Section 3.1).

LANL has performed analyses for ${ }^{85} \mathrm{Kr},{ }^{137} \mathrm{Cs}$, ${ }^{3} \mathrm{H}$, and ${ }^{90} \mathrm{Sr}$. The ${ }^{85} \mathrm{Kr}$ results from pressurized water samples taken in 1977 and 1978 clustered in the range of $2-3 \mathrm{dpm} / \mathrm{L}$ at $T_{0} ;{ }^{137} \mathrm{Cs}$ was not detected. The results of ${ }^{90} \mathrm{Sr}$ determinations by LANL and EAL/LLNL are summarized in Table 2-14. When probable chemical yields for the EAL determinations are considered, these results are in agreement with LANL's 1978 results.

Chemical analyses of UE2ce water have been performed by the USGS and by LLNL. The results are summarized in Table 2-15. 
Table 2-13. Analysis of Nash satellite well (UE2ce) samples calculated to day 74 (1978).

\begin{tabular}{|c|c|c|c|c|c|c|c|c|c|c|c|c|c|}
\hline \multirow{2}{*}{$\begin{array}{l}\text { Sample } \\
\text { date, } \mathrm{m}^{3} \\
\text { total }\end{array}$} & \multirow{2}{*}{$\begin{array}{c}\text { Net } \\
\text { vol (L) } \\
\text { [salt } \\
\text { wt }(\mathrm{g})]\end{array}$} & \multirow{2}{*}{$\begin{array}{l}\text { Filter } \\
\text { used }\end{array}$} & \multicolumn{10}{|c|}{$\mathrm{dpm} / \mathrm{L}( \pm 1 \mathrm{std} \operatorname{dev} \%)$} & \multirow{2}{*}{$\begin{array}{c}\text { Ratio } \\
{ }^{235} U{ }^{238} U\end{array}$} \\
\hline & & & ${ }^{22} \mathrm{Na}$ & ${ }^{40} \mathrm{~K}$ & ${ }^{60} \mathrm{Co}$ & ${ }^{106} \mathrm{Ru}$ & ${ }^{125} \mathrm{Sb}$ & ${ }^{137} \mathrm{Cs}$ & ${ }^{155} \mathrm{Eu}$ & ${ }^{3} \mathrm{H}^{\mathrm{a}}$ & ${ }^{235} \mathbf{U}$ & ${ }^{238} \mathbf{U}$ & \\
\hline $\begin{array}{l}10 / 9 / 80 \\
13,969\end{array}$ & $\begin{array}{l}1775.0 \\
{[628]}\end{array}$ & $1.0 \mu \mathrm{m}$ & $\begin{array}{l}0.39 \\
(12.76 \%)\end{array}$ & $\begin{array}{l}23.50 \\
(1.40 \%)\end{array}$ & $<0.002$ & $<0.5$ & $<0.02$ & $\begin{array}{l}0.02 \\
(17.00 \%)\end{array}$ & $\begin{array}{l}0.07 \\
(21.70 \%)\end{array}$ & $\mathbf{N A}^{\mathbf{b}}$ & $\begin{array}{l}0.15 \\
(6.70 \%)\end{array}$ & $\begin{array}{l}3.96 \\
(2.60 \%)\end{array}$ & 0.038 \\
\hline $\begin{array}{l}7 / 9 / 82 \\
22,681\end{array}$ & $\begin{array}{l}734.0 \\
{[393]}\end{array}$ & $1.0 \mu \mathrm{m}$ & $\begin{array}{l}0.98 \\
(5.30 \%)\end{array}$ & $\begin{array}{l}40.90 \\
(3.90 \%)\end{array}$ & $<0.002$ & $<1.3$ & $<0.02$ & $\begin{array}{l}0.03 \\
(14.50 \%)\end{array}$ & $\begin{array}{l}0.04 \\
(45.00 \%)\end{array}$ & $\begin{array}{l}4.40 \times 10^{7} \\
(<1 \%)\end{array}$ & $\begin{array}{l}0.28 \\
(16.30 \%)\end{array}$ & $\begin{array}{l}2.13 \\
(7.50 \%)\end{array}$ & 0.130 \\
\hline $\begin{array}{l}8 / 10 / 83 \\
40,285\end{array}$ & $\begin{array}{l}175.0 . \\
{[77.36]}\end{array}$ & $0.45 \mu \mathrm{m}$ & $\begin{array}{l}1.11 \\
(11.20 \%)\end{array}$ & $\begin{array}{l}24.87 \\
(2.60 \%)\end{array}$ & $\begin{array}{l}0.31 \\
(26.00 \%)\end{array}$ & $<0.06$ & $<0.12$ & $\begin{array}{l}0.14 \\
(16.40 \%)\end{array}$ & $\begin{array}{l}0.36 \\
(19.40 \%)\end{array}$ & $3.92 \times 10^{7}$ & $\begin{array}{l}0.11 \\
(13.10 \%)\end{array}$ & $\begin{array}{l}2.28 \\
(7.60 \%)\end{array}$ & 0.050 \\
\hline
\end{tabular}

a Tritium values from various sources (LANL, REECo, LLNL).

b NA = not available.

Table 2-14. ${ }^{90} \mathrm{Sr}$ in UE2ce water, calculated to $1 / 19 / 67$.

\begin{tabular}{llll}
\hline Sample date & Volume & Activity (dpm/mL) & Laboratory (reference) \\
\hline $08 / 03 / 77$ & $200 \mathrm{~mL}$ & $\leq$ Background & LANL (24) \\
$08 / 04 / 77$ & $200 \mathrm{~mL}$ & $\leq 0.005$ & LANL (24) \\
$09 / 29 / 77$ & $200 \mathrm{~mL}$ & 0.016 & LANL (24) \\
$11 / 28 / 77$ & $200 \mathrm{~mL}$ & $\leq$ Background & LANL (24) \\
$11 / 29 / 77$ & $200 \mathrm{~mL}$ & $\leq 0.03$ & LANL (24) \\
$12 / 09 / 77$ & $200 \mathrm{~mL}$ & $\leq$ Background & LANL (24) \\
$03 / 12 / 78$ & $500 \mathrm{~mL}$ & $\leq$ Background & LANL (25) \\
$03 / 13 / 78$ & $500 \mathrm{~mL}$ & $\leq$ Background & LANL (25) \\
$03 / 23 / 78$ & $500 \mathrm{~mL}$ & $\leq$ Background & LANL (25) \\
$03 / 24 / 78$ & $500 \mathrm{~mL}$ & $\leq$ Background & LANL (25) \\
$08 / 10 / 78$ & $500 \mathrm{~mL}$ & $\mathbf{0 . 0 0 8 9}$ & LANL (26) \\
$08 / 14 / 78$ & $500 \mathrm{~mL}$ & 0.012 & LANL (26) \\
$08 / 28 / 78$ & $500 \mathrm{~mL}$ & 0.015 & LANL (26) \\
$09 / 01 / 78$ & $500 \mathrm{~mL}$ & 0.014 & LANL (26) \\
$10 / 09 / 80^{\mathrm{a}}$ & $319 \mathrm{~L}$ & 0.00090 & EAL/LLNL \\
$02 / 22 / 82$ & $263 \mathrm{~L}$ & $\mathbf{0 . 0 0 0 7 4}$ & EAL/LLNL \\
$05 /(2+11) / 82^{\mathrm{b}}$ & & $\leq$ Background & LANL (27) \\
$05 /(18+26) / 82^{\text {b }}$ & & $\leq$ Background & LANL (27) \\
FY83 & & $\leq$ Background & LANL (28) \\
\hline
\end{tabular}

a Values are averaged for two replicates.

b Composite samples.

c See Section 2.3. Results are not corrected for chemical yield. 


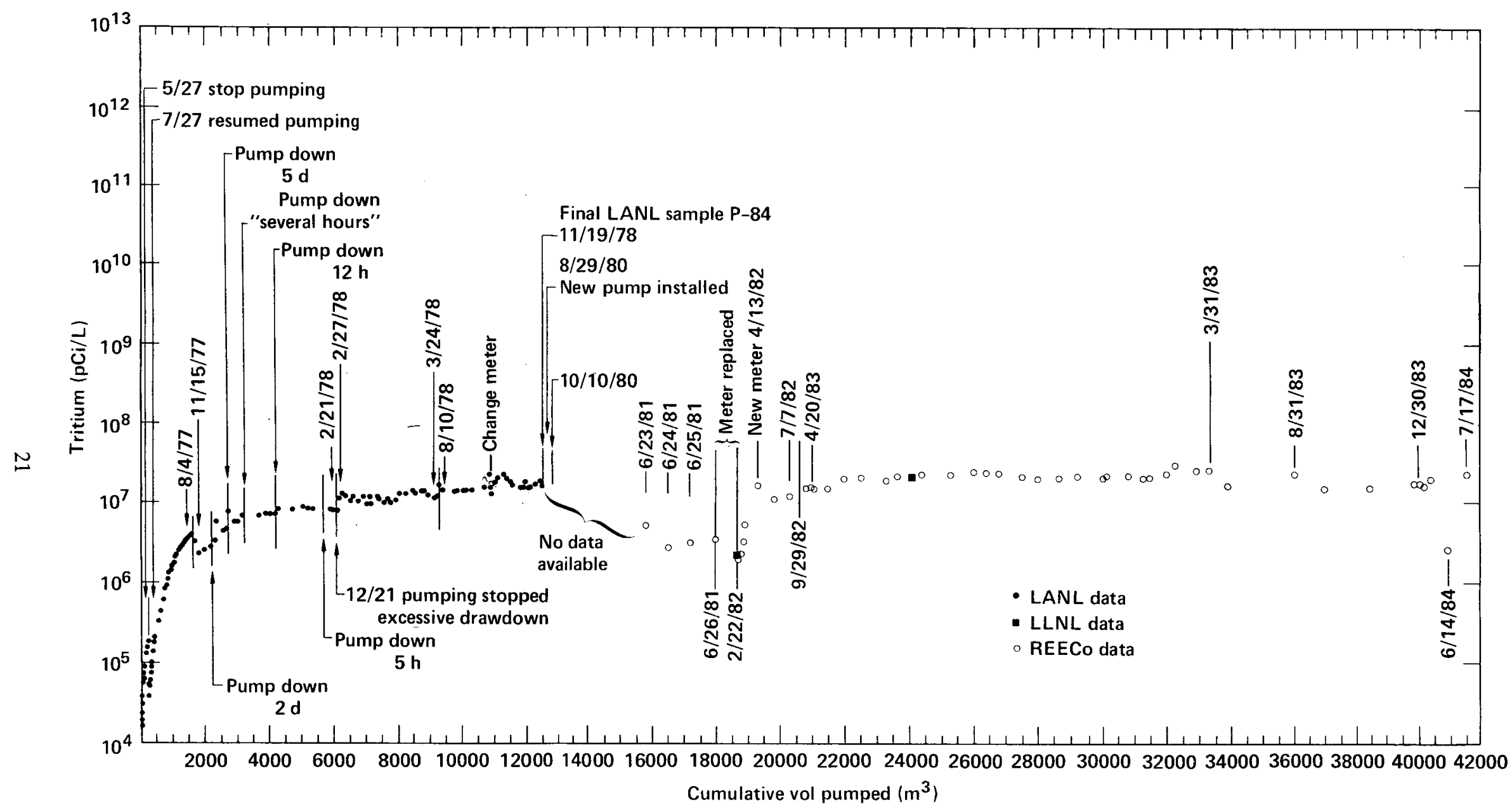

Figure 2-6. Nash (UE2ce) tritium history. Tritium values are calculated to March 15, 1978. 
Table 2-15. Chemical analysis of ground-water samples from UE2ce.

Mean values are given in units of $\mathrm{mg} / \mathrm{L}( \pm 1 \mathrm{std} \operatorname{dev} \%)$.

\begin{tabular}{|c|c|c|c|c|}
\hline Chemical & $\begin{array}{c}1977 \\
\text { USGS } \\
18 \text { samples }\end{array}$ & $\begin{array}{c}1978 \\
\text { USGS } \\
10 \text { samples }\end{array}$ & $\begin{array}{c}1983 \\
\text { LLNL } \\
2 \text { samples }\end{array}$ & $\begin{array}{c}1984 \\
\text { LLNL } \\
3 \text { samples }\end{array}$ \\
\hline $\mathbf{K}^{+}$ & $23(1 \%)$ & $34(13 \%)$ & $22.1(0.3 \%)$ & $22.3(2 \%)$ \\
\hline $\mathrm{Ca}^{+2}$ & $88(8 \%)$ & $97(13 \%)$ & $70.9(0.4 \%)$ & $94.7(0.3 \%)$ \\
\hline $\mathrm{Mg}^{+2}$ & $37(4 \%)$ & $44(7 \%)$ & $31.4(0.0 \%)$ & $39.9(0.1 \%)$ \\
\hline $\mathrm{Sr}^{+2}$ & - & - & - & 0.27 \\
\hline $\mathrm{Na}^{+}$ & $41(2 \%)$ & $51(4 \%)$ & $45.8(0.2 \%)$ & $62.7(0.5 \%)$ \\
\hline $\mathrm{Li}^{+}$ & - & 一 & - & 0.17 \\
\hline $\mathrm{Cl}^{-}$ & $38(17 \%)$ & $103(26 \%)$ & $49.2(<0.05 \%)$ & $108.8(<0.5 \%)$ \\
\hline $\mathbf{F}^{-}$ & $0.7(0.1 \%)$ & $0.7(0.1 \%)$ & $1.05(<0.05 \%)$ & $0.9(<0.5 \%)$ \\
\hline $\mathrm{SO}_{4}^{-2}$ & $25(3 \%)$ & $32(3 \%)$ & $56.8(0.05 \%)$ & $32.6(<0.5 \%)$ \\
\hline $\mathrm{HCO}_{3}^{-}$ & $499(33 \%)$ & $444(53 \%)$ & $620(3 \%)$ & $619.0(3 \%)$ \\
\hline $\mathrm{SiO}_{2}$ & $81(3 \%)$ & $71(8 \%)$ & 67.7 & 69.1 \\
\hline pH & $7.1(0.2 \%)$ & $6.9(0.3 \%)$ & $7.5(0.1 \%)$ & $6.6(0.5 \%)$ \\
\hline Temperature & $34.1(0.8 \%)$ & $32.5(4.1 \%)$ & NA & $33.2(1.0 \%)$ \\
\hline
\end{tabular}

\subsubsection{Discussion}

The results of the chemical and radiochemical analyses of UE2ce water are qualitatively consistent but quantitatively rather variable. ${ }^{3} \mathrm{H},{ }^{85} \mathrm{Kr}$, and ${ }^{22} \mathrm{Na}$ are definitely present, and there is an indication of very low levels of ${ }^{90} \mathrm{Sr} .{ }^{3} \mathrm{H}$ and ${ }^{85} \mathrm{Kr}$ are volatile products that may have been injected some distance into the formation beyond the cavity boundary, and ${ }^{22} \mathrm{Na}$ is probably the result of fast neutron $(n, 2 n)$ reactions with natural ${ }^{23} \mathrm{Na}$ in the minerals surrounding the detonation. All three nuclides are relatively mobile, and their production and transport modes are such that their presence in the ground water does not necessarily indicate direct interaction of ground water with the cavity. ${ }^{90} \mathrm{Sr}$, if attributable to the Nash detonation, might be more indicative of an aqueous transport pathway from the cavity to the satellite well; however, the observed levels are so low and variable that it is difficult to be certain that they are not caused by sample contamination, and ${ }^{90} \mathrm{Sr}$ can be produced by decay of volatile ${ }^{90} \mathrm{Br}$ and ${ }^{90} \mathrm{Sr}$ precursors.

Four main factors may contribute to the variations in sample chemistry and activity: (1) The $8 / 10 / 83$ sample, which shows the highest and most varied inventory of radionuclides, was the only one filtered through Nuclepore filters. Because LANL has shown that these filters contribute significantly to the blank levels of solutions passed through them (see Section 3.3.), we discount the significance of those nuclide results that are substantially different from the preceding and following samples. (2) The pumping at UE2ce has been intermittent and the rates variable. (3) The Paleozoic aquifer is a fractured (hence inhomoge- neous) rather than a porous medium, and the sampling location is relatively close to the tuffcarbonate interface. (4) Temporary perturbations in the ground-water flow regime may have been caused by other detonations in the vicinity.

The data suggest that there is normally no interaction between the equilibrium water table and the cavity. We cannot, however, eliminate the possibility of temporary interactions because of detonation-induced water level fluctuations or of enhanced unsaturated zone recharge through the cavity-chimney system.

In spite of the uncertainties associated with the system, it remains of interest from an RNM standpoint because it is the only documented occurrence of radionuclide contamination of the regionally important carbonate aquifer system.

\subsection{Bilby (U3cn)}

\section{(Contributors: R. W. Buddemeier, J. Rego, and} J. Scholten)

The Bilby Event (located beneath Yucca Flat, Fig. 1-1) was the first detonation below the water table at NTS. ${ }^{29}$ It was fired on September 9, 1963, had a yield of approximately $200 \mathrm{kt}$, and produced a cavity with a radius of about $87 \mathrm{~m} \cdot{ }^{30}$ The chimney and cavity began filling with ground water after the chimney collapse, and the water level returned to the pre-shot water table elevation by the end of $1968 .^{29}$

The geology of the Bilby site is described in Table 2-16; the formations described are found throughout much of NTS with variations primarily in the thickness of rock types. The stratigraphy was determined from lithographic core samples 
taken during drilling of the satellite well (U3cn5). ${ }^{30}$ These samples compare well with the lithographic $\log$ of the reentry hole (U3cnPS2). Figure 2-7 shows a section through the site and then wells of interest.

Soon after the reentry hole to the cavity (U3cnPS2) was drilled, the pipe was crimped below the water table at $587 \mathrm{~m}^{29}$ by additional chimney collapse. This left the reentry well open for sampling only in the chimney environment, where it was perforated in the interval $512-527 \mathrm{~m}$.

Drilling of the Bilby satellite well (U3cn5) began in September 1965. The well was drilled primarily to determine the depth of the Paleozoic rocks beneath the Bilby site and the distribution and intensity of radioactivity surrounding the emplacement hole. The well, located $122 \mathrm{~m} \mathrm{SE}$ of U3cnPS2, was drilled to a depth of $922 \mathrm{~m}$, cased to $863 \mathrm{~m}$, and cemented in the interval $837-863 \mathrm{~m}$ so that water was produced only from the Paleozoic rocks. At its point of closest approach, the U3cn5 hole is $129 \mathrm{~m}$ from the working point and approximately $47 \mathrm{~m}$ from the cavity wall. The casing ends $150 \mathrm{~m}$ below the working point and approximately $63 \mathrm{~m}$ below the bottom of the cavity, which is located only $60 \mathrm{~m}$ above the TertiaryPaleozoic contact. Prior to pump failure in 1981, $3.03 \times 10^{6} \mathrm{~m}^{3}$ was pumped from rocks in the Paleozoic carbonate aquifer. ${ }^{30}$

The U3cnPS2-U3cn5 chimney-satellite pair is considered an ideal location to test for the possibility of Paleozoic aquifer contamination for three reasons: the satellite is cased into the Paleozoic rocks, the event was contained in the overlying tuff near its lower boundary, and rapid transmission of hydraulic pressure during the event suggested the possibility of communication between the two aquifers. ${ }^{30}$ Tables 2-17 and 2-18 present chronologic summaries of the installation, testing, and sampling of wells U3cnPS2 and $\mathrm{U} 3 \mathrm{cn} 5$.

\subsubsection{Results}

Table 2-19 summarizes the available LLNL and LANL gamma spectrometry and tritium data for samples from well U3cnPS2, and Table 2-20 presents the results for two large-volume samples from U3cn5 analyzed by LLNL. Beetem et al. ${ }^{31}$ studied the dissolved radionuclides in the water samples from the Bilby chimney in 1964. By converting all activities to a common date and unit, the data from 1964 can be compared with the more recent analyses. $T_{0}+14 \mathrm{y}$ is used as a reference date; it coincides with the first major sampling of U3cnPS2 after the chimney well was filled. The recalculated 1964 data are presented in Table 2-21 along with the results of the two subsequent large-volume samples for comparison purposes. The 1964 data are from a period when the chimney and cavity were still filling with ground water. The water level in the chimney has presumably been in equilibrium with the surrounding water table since 1968 .

Garber $^{29}$ reports some USGS data on ${ }^{90} \mathrm{Sr}$, ${ }^{137} \mathrm{Cs}$, U, gross beta, and gross alpha from pump test samples in the period 1964-66. LLNL submitted aliquots of archived large-volume salt samples to EAL for plutonium and ${ }^{90} \mathrm{Sr}$ analyses (see Section 2.1.2) and performed plutonium analysis on one chimney sample. Table 2-22 summarizes the additional data on specific radionuclides from these sources.

\subsubsection{Discussion}

U3cn5. The satellite well was monitored for more than 10 years without detecting any radioactivity. ${ }^{33}$ The two large-volume samples reported in Table 2-20 represent the highest analytical sensitivity achieved, but in neither case was significant activity detected. The tritium levels reported are below the activity of contemporary rainwater at

Table 2-16. Bilby stratigraphy.

\begin{tabular}{|c|c|c|c|}
\hline Layer & Formation & Description & Depth \\
\hline 1 & Alluvium & $\begin{array}{l}\text { Medium to coarse sand, gravel and cobble size fragments } \\
\text { colored light brown or tan. }\end{array}$ & $0-282 \mathrm{~m}(0-925 \mathrm{ft})$ \\
\hline 2 & Timber mountain tuff & $\begin{array}{l}\text { Tertiary (younger) volcanic rocks deposited under air, } \\
\text { water, or gaseous clouds (welded tuff) colored white to } \\
\text { purplish brown. }\end{array}$ & $282-431 \mathrm{~m}(925-1414 \mathrm{ft})$ \\
\hline 3 & Indian trail formation & $\begin{array}{l}\text { Similar to timber mountain tuff with yellow in upper to } \\
\text { reddish-brown in lower regions. }\end{array}$ & $431-860 \mathrm{~m}(1414-2822 \mathrm{ft})$ \\
\hline 4 & Lower Paleozoic rocks & Limestone, dolomite, and quartzite. & $860-924 \mathrm{~m}(2822-3032 \mathrm{ft})$ \\
\hline
\end{tabular}




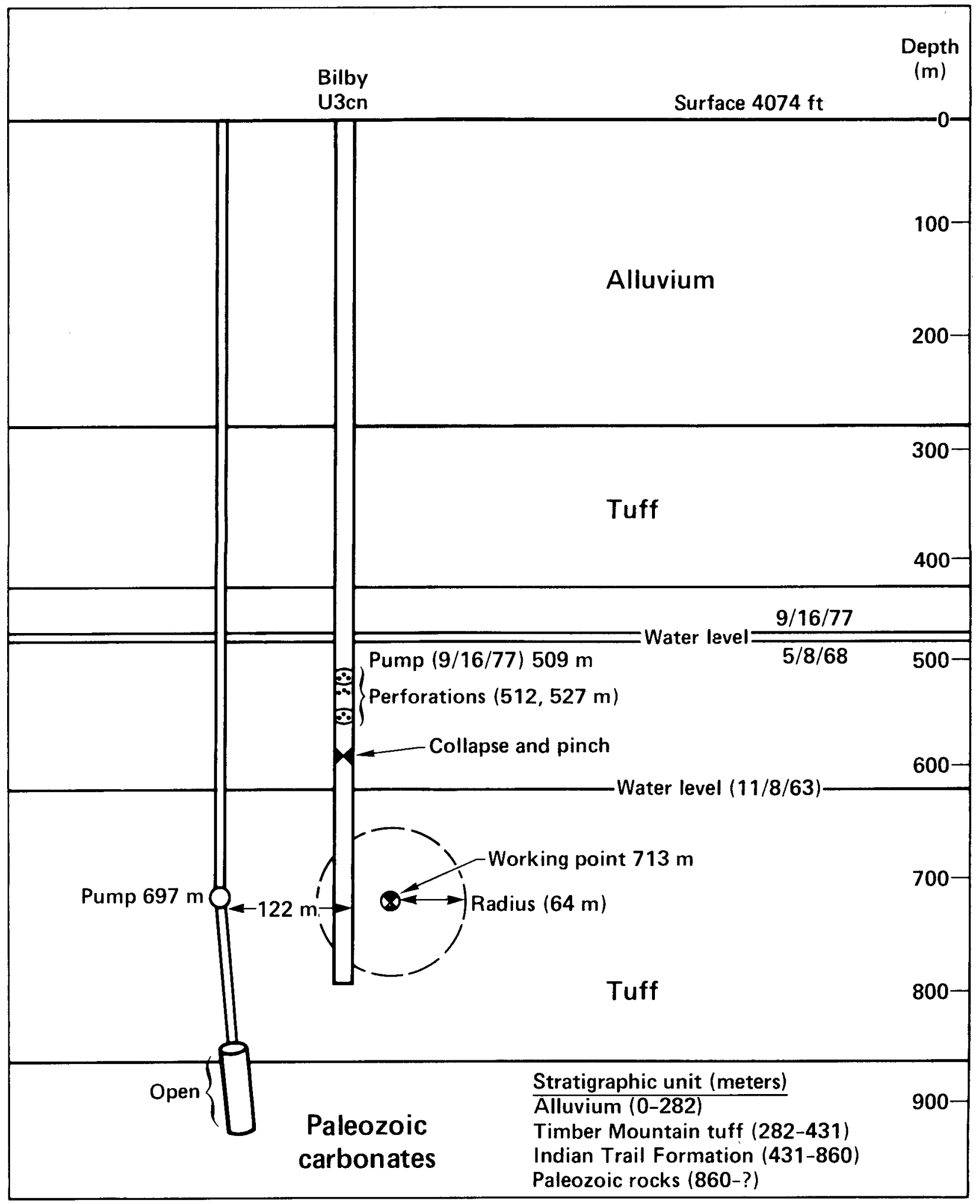

Figure 2-7. Bilby site cross section. 
Table 2-17. Bilby (U3cnPS2) chronology.

\begin{tabular}{ll}
\hline \multicolumn{1}{c}{ Date } & \multicolumn{1}{c}{ Chronology } \\
\hline $9 / 13 / 63$ & Detonation; yield $200 \mathrm{kt}$; working point at $712.9 \mathrm{~m}$. \\
$9 / 23 / 63$ & U3cnPS2 drilled into the cavity at a horizontal distance of $10 \mathrm{~m}$ from the working \\
& point. Total depth $793.4 \mathrm{~m}$; cased to $792.8 \mathrm{~m}$; perforated from 579.1 to $792.5 \mathrm{~m}$. \\
$10 / 10 / 63$ & Casing collapse; restriction at $587 \mathrm{~m}$. \\
$7 / 10 / 64$ & Submersible pump lowered to $577 \mathrm{~m}$. \\
$7 / 11 / 64-1 / 6 / 65$ & Pump tests \#1 and \#2 by USGS. \\
$6 / 23 / 65$ & Packer set in hole at $561.4 \mathrm{~m}$. Perforations at 512 and $527 \mathrm{~m}$. Submersible pump \\
$7 / 7-11 / 65$ & installed. Intake at $521.8 \mathrm{~m}$. \\
$5 / 3-16 / 66$ & Pump test \#4; rate 54.0 to $57.8 \mathrm{~m}^{3} /$ day. \\
$9 / 11-14 / 69$ & Pump test \#5; rate 27.2 to $60.0 \mathrm{~m}^{3} /$ day. \\
$6 / 77$ & Pumped $186.2 \mathrm{~m}^{3}$ and collected samples for chemistry and radionuclide analysis. \\
$9 / 29 / 77$ & Pump failed. \\
$9 / 29-30 / 77$ & New pump lowered to $509 \mathrm{~m}$. \\
$10 / 20 / 80$ & LLNL collected and analyzed a series of samples. \\
$10 / 21 / 81$ & LLNL collected large-volume sample. \\
$12 / 21 / 81$ & LLNL collected large-volume sample. \\
$4 / 18 / 84$ & Pump operable. \\
\hline
\end{tabular}

a Pump test samples were analyzed by USGS mobile field laboratory, which determined results from a number of methods: well yield, water temperature, water depth, specific conductivity and $\mathrm{pH}$, alkalinity, dissolved oxygen, and $\mathrm{CO}_{2}$ content on selected samples.

Table 2-18. Bilby satellite (U3cn5) chronology.

\begin{tabular}{ll}
\multicolumn{1}{c}{ Date } & \multicolumn{1}{c}{ Chronology } \\
\hline $9 / 24 / 65$ & Drilling started $122 \mathrm{~m}$ south from U3cn. Work stoppage delayed completion. \\
$2 / 9 / 66$ & Total depth $922 \mathrm{~m}$; cased to $863 \mathrm{~m}$. \\
$3 / 6 / 67-9 / 22 / 69$ & Well pumped continuously for $2-1 / 2$ years. \\
$9 / 69-5 / 73$ & Intermittent pumping. Pump failure after $2.27 \times 10^{4} \mathrm{~m}^{3}$. \\
1979 & Pumping resumed. \\
$10 / 21 / 80$ & Samples taken by LLNL. \\
$10 / 20 / 81$ & Samples taken by LLNL. \\
$12 / 81$ & Pump failure after $3.03 \times 10^{6} \mathrm{~m}^{3}$. \\
\hline
\end{tabular}

NTS, and the small ${ }^{137} \mathrm{Cs}$ value for the 1980 sample is comparable to values observed for "background" samples from wells far removed from any radionuclide source. It is clear that there was no significant radionuclide migration from the cavity to U $3 \mathrm{cn} 5$ over the course of the experiment.

U3cnPS2. Before attempting to interpret the changes in chimney water radioactivity, the comparability of the samples and the true precision and accuracy of the analyses need to be assessed. For the LLNL and LANL analyses over the period 1977-1982, methods were generally consistent and the series of samples taken at closely spaced intervals on 9/29-30/77 can be considered replicates to a first approximation. Based on the ranges of values observed for this suite of samples and the assumption that the large-volume sample is probably more representative than the preceding small 
Table 2-19. Analysis of Bilby chimney well (U3cn) calculated to day 273 (1977).

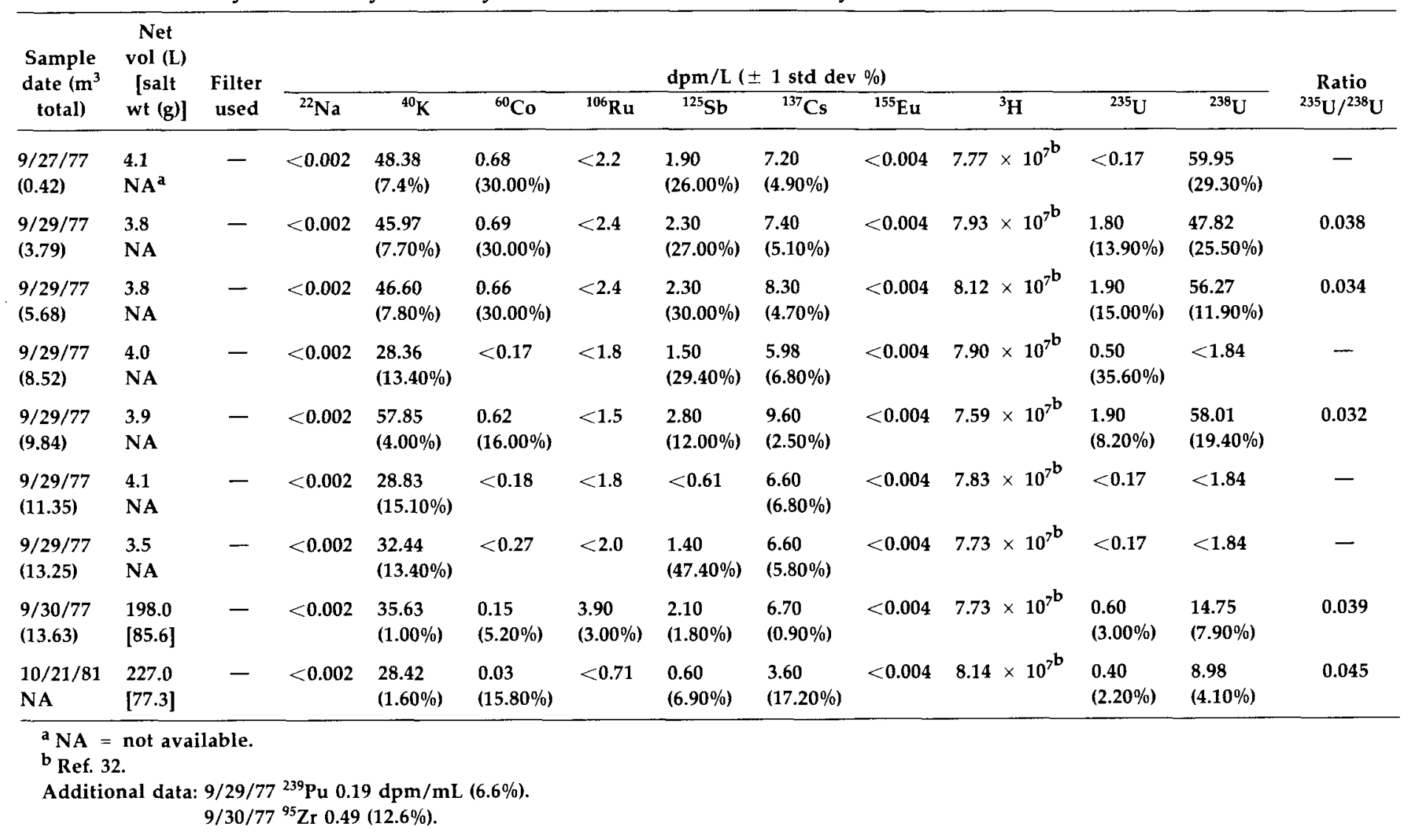

Table 2-20. Analysis of Bilby satellite well (U3cn5) calculated to day 273 (1977).

\begin{tabular}{|c|c|c|c|c|c|c|c|c|c|c|c|c|c|}
\hline \multirow{2}{*}{$\begin{array}{c}\text { Sample } \\
\text { date }\end{array}$} & \multirow{2}{*}{$\begin{array}{c}\text { Net } \\
\text { vol (L) } \\
\text { [salt } \\
\text { wt (g)] }\end{array}$} & \multirow{2}{*}{$\begin{array}{l}\text { Filter } \\
\text { used }\end{array}$} & \multicolumn{10}{|c|}{$\mathrm{dpm} / \mathrm{L}( \pm 1$ std dev \%) } & \multirow{2}{*}{$\begin{array}{c}\text { Ratio } \\
{ }^{235} \mathrm{U} /{ }^{238} \mathrm{U}\end{array}$} \\
\hline & & & ${ }^{22} \mathrm{Na}$ & ${ }^{40} \mathrm{~K}$ & ${ }^{60} \mathrm{Co}$ & ${ }^{106} \mathrm{Ru}$ & ${ }^{125} \mathrm{Sb}$ & ${ }^{137} \mathrm{Cs}$ & ${ }^{155} \mathrm{Eu}$ & ${ }^{3} \mathrm{H}$ & ${ }^{2335} \mathbf{U}$ & ${ }^{238} U$ & \\
\hline $10 / 21 / 80$ & $\begin{array}{l}1509.0 \\
{[593.0]}\end{array}$ & $1.0 \mu \mathrm{m}$ & $<0.002$ & $\begin{array}{l}16.01 \\
(2.20 \%)\end{array}$ & $<0.003$ & $<0.04$ & $<0.01$ & $\begin{array}{l}0.006 \\
(51.30 \%)\end{array}$ & $\begin{array}{l}0.20 \\
(44.30 \%)\end{array}$ & 19.51 & $\begin{array}{l}0.10 \\
(15.10 \%)\end{array}$ & $\begin{array}{l}1.31 \\
(15.30 \%)\end{array}$ & 0.074 \\
\hline $10 / 20 / 81$ & $\begin{array}{l}715.4 \\
{[217.2]}\end{array}$ & $1.0 \mu \mathrm{m}$ & $<0.002$ & $\begin{array}{l}13.35 \\
(1.80 \%)\end{array}$ & $<0.003$ & $<0.07$ & $<0.01$ & $<0.003$ & $\begin{array}{l}0.20 \\
(17.20 \%)\end{array}$ & 5.16 & $\begin{array}{l}0.08 \\
(11.60 \%)\end{array}$ & $\begin{array}{l}1.09 \\
(16.60 \%)\end{array}$ & 0.074 \\
\hline
\end{tabular}


Table 2-21. U3cnPS2 water activity [dpm/L ( $\pm 1 \mathrm{std}$ dev $\%$ ) at $T_{0}+14 \mathrm{y}$.

\begin{tabular}{llll}
\hline Nuclide & $\begin{array}{c}12 / 9 / 64 \\
\text { (Beetem et al.) }\end{array}$ & $\begin{array}{l}9 / 30 / 77 \\
\text { (LLNL) }\end{array}$ & \multicolumn{1}{c}{$\begin{array}{c}10 / 21 / 81 \\
\text { (LLNL) }\end{array}$} \\
\hline${ }^{3} \mathrm{H}$ & $2.4 \times 10^{8}$ & $\begin{array}{l}7.7 \times 10^{7} \\
(<1.0 \%)\end{array}$ & $\begin{array}{l}8.1 \times 10^{7} \\
(<1.0 \%)\end{array}$ \\
${ }^{60} \mathrm{Co}$ & 80 & $\begin{array}{l}0.15 \\
(5.2 \%)\end{array}$ & 0.05 \\
& & 3.9 & $(16 \%)$ \\
${ }^{106} \mathrm{Ru}$ & 0.8 & $(3.0 \%)$ & $<0.71$ \\
& & 2.1 & 0.6 \\
${ }^{125} \mathrm{Sb}$ & 52 & $(1.8 \%)$ & $(7 \%)$ \\
& & 6.7 & 3.6 \\
${ }^{137} \mathrm{Cs}$ & 4.9 & $(0.9 \%)$ & $(2 \%)$ \\
& & $<0.1$ & $\mathrm{ND}^{\mathrm{a}}$ \\
\hline
\end{tabular}

${ }^{\mathbf{a}} \mathrm{ND}=$ not detectable.

Table 2-22. Miscellaneous analyses of Bilby wells [dpm/L ( $\pm 1 \mathrm{std} \mathrm{dev} \%)$ at $\left.T_{0}+14 \mathrm{y}\right]$.

\begin{tabular}{lccc}
\hline Date (lab) & ${ }^{90} \mathrm{Sr}$ & ${ }^{137} \mathrm{Cs}$ & ${ }^{239} \mathrm{Pu}$ \\
\hline U3cnPS2: & & & \\
$7 / 64$ (USGS) & $<6.4$ & 8.6 & $-{ }^{\mathrm{a}}$ \\
12/64 (USGS) & - & 5.0 & - \\
9/77 (LLNL) & - & - & 0.019 \\
10/81 (EAL) & 1.4 & - & 0.002 \\
U3cn5: & & - & $\mathrm{ND}^{\mathrm{b}}$ \\
10/80 (EAL) & $<0.0085$ & - & $\mathrm{ND}$ \\
10/81 (EAL) & $\mathrm{ND}$ & & \\
\hline a Not analyzed for. & &
\end{tabular}

samples, we can make two observations based on the data presented in Table 2-19. (1) No significant decrease in tritium content was noted between 1977 and 1981; the apparent 10\% increase between the 1981 and 1982 samples is on the margin of significance. (2) The data suggest a $40-80 \%$ decrease in the concentrations of ${ }^{60} \mathrm{Co},{ }^{106} \mathrm{Ru},{ }^{125} \mathrm{Sb}$, and ${ }^{137} \mathrm{Cs}$ between 1977 and 1981, but the range of 1977 values is wide enough so that this must be treated as probable rather than quantitatively certain.

The rather substantial "replicate" variations observed can be ascribed to two possible sources. First, the rubble chimney is undoubtedly highly heterogeneous in the spatial distribution of radioactivity, permeability, and sorption or desorption sites, so that small volumes of water that have been incubated in different regions of the chimney may well have substantially different activities. Second, the inclusion of particulate activity may affect the results. The 1977 samples were unfiltered, while the 1981 sample was passed through a $1.0-\mu \mathrm{m}$ filter before evaporation. This was not considered significant at the time, but re'cent experiments at the U20n chimney well have shown that $20-50 \%$ of the total $\mathrm{Co}, \mathrm{Ru}$, and $\mathrm{Cs}$ activity in a pumped sample can be collected on $0.45 \mu \mathrm{m}$ filters (see Sections 2.2 and 3.3). With unfiltered samples, variations in pumping rate, aliquoting, or decanting techniques may cause large variations in the amount of particulate activity included.

In comparing the 1964 data with subsequent analyses (Table 2-21), other considerations must be kept in mind. Beetem et al. filtered their samples through $0.2-\mu \mathrm{m}$ filters, so particulate contamination is less likely than in subsequent samples. However, different methods were employed, and in 1964 the chimney had not completely refilled and was probably still at an elevated temperature. Thus, the geochemical and hydrologic regime may have been quite different from the situation sampled in 1977-82. Taken at face value, the data indicate three conclusions. (1) Tritium levels decreased by $60-70 \%$ between 1964 and the $1977-81$ period. It is probable that most of this change occurred early in the time interval; Garber ${ }^{29}$ reports that tritium levels decreased by $14 \%$ between July and December 1964, and by an additional $11 \%$ between December and the following June. The results are probably more closely related to water table recovery than to steady-state ground-water flow. (2) There is no conclusive evidence of either long-term increase or long-term decrease in the cases of ${ }^{106} \mathrm{Ru}$ and ${ }^{137} \mathrm{Cs}$, but the range of uncertainty is large. (3) ${ }^{60} \mathrm{Co}$ decreased in concentration by almost three orders of magnitude, and ${ }^{125} \mathrm{Sb}$ concentrations decreased by one to two orders of magnitude.

If we treat tritium as a conservative tracer for water movement and assume that all losses are a result of advection and diffusion, then nuclides that disappear more rapidly must have additional sinks (presumably sorption or precipitation) and those that decrease more slowly must have secondary sources (solution or desorption). Cobalt and antimony clearly fall in the former category and apparently had not equilibrated with the medium by the time of the 1964 sampling. It is tempting to look for evidence for secondary sources in the case of ruthenium and cesium, but it is questionable whether the data are good enough to say with any certainty that their rates of change are significantly different from those of tritium. There is certainly no evidence for any long-term net depletion of the latter two by any means other than water flow. 


\subsubsection{Hydrology}

Garber and Johnston ${ }^{30}$ report that well logs and core surveys in the interval adjacent to the cavity showed that some but not all of the fractures intersected by U3cn5 contained readily measurable levels of radioactivity. On the basis of physical and mineralogical examination of the fractures, they concluded that both the contaminated and the uncontaminated fractures were preexisting natural features and not shock-induced. Because water levels in U3cnPS2 had not yet recovered to the levels observed in U3cn5 at the time of drilling, the chimney was downgradient from the satellite. They therefore concluded that the radionuclide transport must have been induced by the blast and was not caused by normal ground-water flow. They remarked on, but could not explain, the selective contamination of some but not all of the fractures.

Measurements made following water table recovery show a slight (a few meters of head at the most) apparent gradient from the cavity to $\mathrm{U} 3 \mathrm{cn} 5$, but with only two observation points it cannot be determined whether the satellite well is situated directly on the axis of maximum gradient or is off to one side.

Pumping rates at U3cn5 have been modest $(\sim 50 \mathrm{gpm})$, and the total volume pumped represents no more than $10 \%$ of the cavity water content. On a subregional scale, fractured rock systems typically are characterized by nonuniform and indirect preferential flow paths rather than by uniform frontal advance of water. Given the modest natural and imposed gradients and the uncertainties as to the actual direction of preferred flow, it is not clear that we should necessarily expect cavity water to have reached U3cn5 yet. If we compare the Bilby system with the Cambric experiment, we can note that the satellite wells are comparable distances from the cavities, that Cambric is situated in alluvium (hence more likely to yield ground-water flow directly downgradient), that the Cambric satellite has been pumped at much higher rates than U $3 \mathrm{cn} 5$ (thus inducing a larger gradient), and that breakthrough at the Cambric satellite did not occur until $>10^{6} \mathrm{~m}^{3}$ had been pumped from the satellite. This comparison strongly suggests that the negative results at Bilby are inconclusive and supports Claassen's contention that "the test period is too short to conclude that Bilby has not and will not contaminate the Paleozoic aquifer." ${ }^{34}$

\subsubsection{Conclusions}

1. Radionuclides from the Bilby cavity did not reach the U3cn5 pumping point over the course of the experiment. This suggests that there has been no rapid or extensive contamination of the Paleozoic aquifer; however, because of the hydrologic uncertainties associated with fracture flow systems and the small gradients and pumped volumes, the results do not rule out the possibility of such contamination.

2. The prompt postshot occurrence of significant activity in natural fractures well beyond the cavity radius indicates that the hydrologic cross section of the radionuclide source considerably exceeds cavity dimensions.

3. Chimney water analyses suggest the existence of an intermediate-term (years to decades) geochemical sink for cobalt and antimony, but not for ruthenium or cesium.

\subsection{Bourbon (U7n)}

\section{(Contributors: J. Rego and R. W. Buddemeier)}

The Bourbon Event (U7n) was detonated on January 20, 1967 and was of low-to-intermediate yield. The working point was at a depth of $560 \mathrm{~m}$ in a silty limestone formation.

Satellite well UE7ns was drilled in 1976 to study the geological and geophysical characteristics of emplacement sites that had demonstrated anomalous seismic signals. The well is located $137 \mathrm{~m} \mathrm{SE}$ of U7n; it was drilled to a total depth of $672 \mathrm{~m}$ and cased to $670 \mathrm{~m}$ with the bottom $62 \mathrm{~m}$ of the casing slotted. At UE7ns, the alluvium-tuff contact is at a depth of $84 \mathrm{~m}$, the tuff-Paleozoic contact is at $503 \mathrm{~m}$, and the static water level is at $601 \mathrm{~m}$. A thrust fault was tentatively identified in the Paleozoic limestone with the top of the fault zone at $594 \mathrm{~m} .{ }^{35}$

A pump was installed in the satellite well, but well yields were so low that only sporadic samples were obtained and it is doubtful that they can be considered fully representative of the formation water. Between 1979 and 1982 tritium values for these samples ranged from 1.0 to $3.7 \mathrm{nCi} / \mathrm{L}^{36}$ In early 1983, a low-flow solar-powered pump was installed and a large-volume sample was collected for LLNL. Table 2-23 presents the results of the analysis of that sample. Shortly after that collection the system failed and was not reactivated until early 1984. Table 2-24 summarizes the pumping rates and tritium activities reported by 
REECo since then. Table 2-25 presents the chronology of operations at UE7ns, and Fig. 2-8 shows the vertical cross section of the study site.

\subsubsection{Discussion}

There are a number of parallels between the Bourbon and Nash sites, but the results obtained to date are significantly different. In both locations, the shot was fired in the limestone just above the water table and the satellite well was completed below the water table within the carbonate. However, Bourbon shows satellite well activities that are only slightly elevated above the regional background for tritium and that give no conclusive evidence for the movement of any other nuclides. The data of Table 2-23 are all at or below the levels attributable to background effects (Section 2.1.1), and there are no indications of the presence of the mobile radionuclides. The only point of interest is the apparent gradual increase in tritium activity since the beginning of the continuous pumping in early 1984 (Table 2-24), but levels are very low compared to those of Nash, and the increase is slow.

Table 2-23. Analysis of Bourbon UE7ns satellite well calculated to day 175 (1983).

\begin{tabular}{|c|c|c|c|c|c|c|c|c|c|c|c|c|c|}
\hline \multirow{2}{*}{$\begin{array}{l}\text { Sampling } \\
\text { date, } \mathbf{m}^{3} \\
\text { pumped }\end{array}$} & \multirow{2}{*}{$\begin{array}{c}\text { Solution } \\
\text { vol (L) } \\
{[\text { salt }} \\
\text { wt }(g)]\end{array}$} & \multirow{2}{*}{$\begin{array}{l}\text { Filter } \\
\text { used }\end{array}$} & \multicolumn{10}{|c|}{$\mathrm{dpm} / \mathrm{L}( \pm 1$ std dev $\%)$} & \multirow{2}{*}{$\begin{array}{c}\text { Ratio } \\
{ }^{235} U /{ }^{238} U\end{array}$} \\
\hline & & & ${ }^{22} \mathrm{Na}$ & ${ }^{40} K$ & ${ }^{60} \mathrm{Co}$ & ${ }^{106} \mathrm{Ru}$ & ${ }^{125} \mathrm{Sb}$ & ${ }^{137} \mathrm{Cs}$ & ${ }^{155} \mathrm{Eu}$ & ${ }^{3} \mathrm{H}$ & ${ }^{235} \mathrm{U}$ & ${ }^{238} \mathrm{U}$ & \\
\hline $\begin{array}{r}6 / 24 / 83 \\
15,675\end{array}$ & $\begin{array}{l}200.0 \\
{[64.4]}\end{array}$ & $0.45 \mu \mathrm{m}$ & $<0.002$ & $\begin{array}{l}11.01 \\
(2.00 \%)\end{array}$ & $\begin{array}{l}0.02 \\
(17.0 \%)\end{array}$ & $<0.05$ & $<0.01$ & $\begin{array}{l}0.09 \\
(6.30 \%)\end{array}$ & $<0.004$ & $<3000^{a}$ & $\begin{array}{l}0.007 \\
(78.0 \%)\end{array}$ & $<0.27$ & 0.026 \\
\hline
\end{tabular}

${ }^{a}$ REECo analysis.

Table 2-24. Bourbon REECo tritium log.

\begin{tabular}{lcccc}
\hline $\begin{array}{c}\text { Sample } \\
\text { date }\end{array}$ & $\begin{array}{c}\text { Volume } \\
\text { (gal) }\end{array}$ & $\begin{array}{c}{ }^{3} \mathrm{H} \\
(\mu \mathrm{Ci} / \mathrm{mL})\end{array}$ & $\begin{array}{c}{ }^{3} \mathrm{H} \\
(\mathrm{dpm} / \mathrm{L})\end{array}$ & $\begin{array}{c}\text { Rel. \% error } \\
(2 \mathrm{std} \text { dev })\end{array}$ \\
\hline $6 / 24 / 83$ & 15,675 & $<1.3 \times 10^{-6}$ & $<2886$ & 26.0 \\
$4 / 23 / 84$ & $62,300^{\mathrm{a}}$ & $1.21 \times 10^{-6}$ & 2686 & 15.4 \\
$5 / 24 / 84$ & 102,980 & $1.98 \times 10^{-6}$ & 4396 & 30.9 \\
$6 / 15 / 84$ & 148,010 & $1.70 \times 10^{-6}$ & 3770 & 18.1 \\
$7 / 18 / 84$ & 217,512 & $2.32 \times 10^{-6}$ & 5150 & 12.7 \\
$8 / 8 / 84$ & 260,710 & $2.51 \times 10^{-6}$ & 5570 & 12.3 \\
$9 / 5 / 84$ & 313,600 & $2.59 \times 10^{-6}$ & 5750 & 13.2 \\
$10 / 03 / 84$ & 370,940 & $2.85 \times 10^{-6}$ & 6327 & \\
\hline
\end{tabular}

a Pumping restarted after being down since $7 / 83$.

Table 2-25. Bourbon satellite (UE7ns) chronology.

\begin{tabular}{ll}
\hline \multicolumn{1}{c}{ Date } & \multicolumn{1}{c}{ Chronology } \\
\hline $1 / 20 / 67$ & Detonation; hole U7n; intermediate yield; working point $559.7-\mathrm{m}$ depth. \\
$6 / 3 / 76-7 / 15 / 76$ & $\begin{array}{l}\text { UE7ns drilled; cased to } 670.2 \mathrm{~m} \text {; casing perforated from } 608.2 \text { to } 670.2 \mathrm{~m} \text {. Location } 137.1 \mathrm{~m} \text { from UE7. } \\
\text { Water table at } 601.1 \mathrm{~m}, \text { pump at } 660 \mathrm{~m} .\end{array}$ \\
$10 / 26 / 78$ & Tritium reported as $9.5 \times 10^{2} \mathrm{dpm} / \mathrm{L}$. \\
$11 / 30 / 78-2 / 16 / 82$ & Monitored regularly; pump produced small quantities of water. \\
$2 / 83$ & Solar pump installed. \\
$6 / 24 / 83$ & REECo assisted in sample collection. 200 L processed. \\
$4 / 9 / 84$ & Solar pump restarted after major parts failure some time after 6/83 sampling. \\
$4 / 18 / 84$ & Field measurement and large-volume LLNL sampling. \\
\hline
\end{tabular}




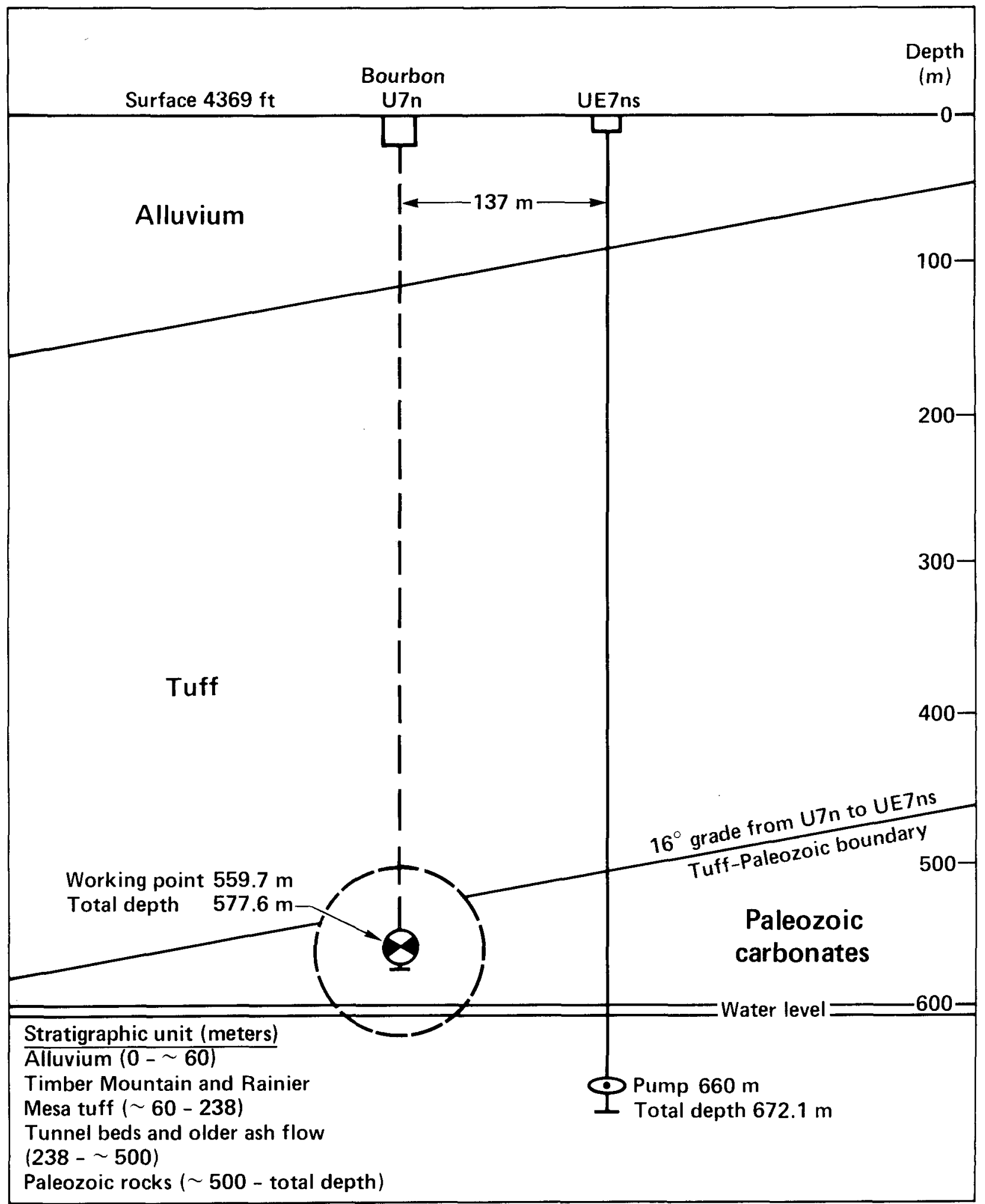

Figure 2-8. Bourbon site cross section. 
The hydrologic setting here is even more complex than in the other well sites. As usual, we lack detailed knowledge of the local natural ground-water gradient, and the very slow pumping rate possible from the satellite well is almost certainly inadequate to induce a significant artificial gradient. In addition, the possible presence of a fault zone between the working point and the satellite well production depth further complicates any interpretation. As at Nash, we are unable to say whether or not the shot cavity has interacted with the local ground-water body.

It is safe to say that there is no indication of significant radionuclide migration from the cavity to the satellite well and that the low water yield makes the site inappropriate for a serious pumping experiment. Further analysis is probably not justified unless routine tritium monitoring indicates the breakthrough of higher activity water or new questions or techniques (e.g., ${ }^{99} \mathrm{Tc}$ ) are developed.

\subsection{Faultless (UC1P2SR)}

(Contributors: R. W. Buddemeier, J. Rego, and J. Schweiger)

\subsubsection{Introduction}

The Faultless site in Hot Creek Valley, central Nevada, is the only site in the RNM Program that is located off NTS. The nuclear event took place in January 1968, at a depth of $975 \mathrm{~m}$ in unwelded tuff. The drillback hole (P2SR) was open to $802 \mathrm{~m}$. The water level has been steadily increasing since the event and is currently at $365 \mathrm{~m}$ below the surface. Table 2-26 gives the history of activities at UC1P2SR.

As part of an annual sampling program, the Faultless well and two satellite wells ( $\mathrm{HTH}-1$, located $915 \mathrm{~m} \mathrm{SE}$, and HTH-2, located $762 \mathrm{~m} \mathrm{SE}$ of UC1P2SR) were sampled during the period of July 18-21, 1983. Field sampling and analysis were carried out by an interagency team consisting of personnel from the USGS, the U.S. Environmental Protection Agency (EPA), and LLNL. The primary purpose of the trip was to evaluate the chemistry, radionuclide content, and water levels in the well system for comparison with previous results. Secondary objectives included intercalibration of the results obtained by the different groups and comparison and assessment of sampling and analytical techniques.

This report contains the results of the LLNL field and laboratory analyses; for comparison and completeness, the USGS field results are also cited. Table 2-27 summarizes depth, time, temperature, dissolved oxygen, Eh, $\mathrm{pH}$, alkalinity, and conductivity data for all field analyses (USGS/EPA as well as LLNL samples). The results are compared with previous Faultless well sample analyses ${ }^{37}$ and the significance and reliability of the results are discussed. The sampling techniques and the dissolved gas and redox system analyses are discussed in Section 3.2.

\subsubsection{Methods}

Chemical analyses were carried out by the methods described in Appendix A.

Table 2-26. Faultless (UC1P2SR) chronological history.

\begin{tabular}{|c|c|}
\hline Date & Event \\
\hline $1 / 19 / 68$ & $\begin{array}{l}\text { Location: Supplemental Central Nevada Test Area. Detonation; hole UC1P2SR; yield range } 200-1000 \mathrm{kt} \text {; } \\
\text { working point } 975.4 \mathrm{~m} \text {. Pre-shot water level } 170.7 \mathrm{~m} \text {. Total depth of emplacement hole } 1083.3 \mathrm{~m} \text {. }\end{array}$ \\
\hline $2 / 20 / 68$ & $\begin{array}{l}\text { UC1P2SR location } 300 \mathrm{ft} \text { north of UC1P2SR. Slant drilled to } 1022.6 \mathrm{~m} \text {. Cased to } 851 \mathrm{~m} .1022 .6 \mathrm{~m} \text {. } \\
\text { Cased to } 851 \mathrm{~m} \text {. Perforations at } 350.5 \text { and } 851 \mathrm{~m} \text {. }\end{array}$ \\
\hline $4 / 9 / 68$ & $\begin{array}{l}\text { Water level } 653.5 \mathrm{~m} \text {. Water samples collected on a periodic basis. Sampled from the upper } \\
\text { part of the drill hole because of casing constriction at } 679.7 \mathrm{~m} \text {. }\end{array}$ \\
\hline 9/69-11/70 & No sampling. Water level dropped to less than $680 \mathrm{~m}$, below the restriction in the casing. \\
\hline $11 / 70$ & Constriction was opened and entire water column sampled at $15-\mathrm{m}$ intervals. \\
\hline $12 / 2 / 70$ & Water level $771 \mathrm{~m}$. \\
\hline $3 / 31 / 71$ & Water level $791 \mathrm{~m}$. Water level rising at about $0.15 \mathrm{~m} / \mathrm{day}$. \\
\hline $1972-1981$ & Well sampled annually by USGS. \\
\hline $11 / 16 / 82$ & Water level $355 \mathrm{~m}$. \\
\hline $7 / 18-21 / 83$ & $\begin{array}{l}\text { Joint USGS, EPA, and LLNL sampling effort. Water level } 340 \mathrm{~m} \text {. LLNL samples taken at } 545.6,637.0 \text {, } \\
728.5 \text {, and } 789.4 \mathrm{~m} \text {. }\end{array}$ \\
\hline
\end{tabular}


Table 2-27. Faultless field measurements.

\begin{tabular}{|c|c|c|c|c|c|c|c|c|}
\hline $\begin{array}{l}\text { Depth } \\
\text { (ft) }\end{array}$ & $\begin{array}{l}\text { Time } \\
\text { (h) }\end{array}$ & $\begin{array}{c}\text { Temp } \\
\left({ }^{\circ} \mathrm{C}\right)\end{array}$ & $\begin{array}{c}\text { DO } \\
(\mathrm{ppm})\end{array}$ & Eh $(\mathrm{mV})$ & Eh (mV) (NHE) & $\mathrm{pH}$ & $\begin{array}{c}\text { Alkalinity } \\
\left(\mathrm{ppm} \mathrm{CaCO}_{3}\right)\end{array}$ & $\begin{array}{l}\text { Conductivity } \\
(\mathrm{ohm}-\mathrm{cm})^{-1}\end{array}$ \\
\hline \multicolumn{9}{|c|}{ 7/19/83 Well HTH-1 water level (WL) $534.5 \mathrm{ft}$} \\
\hline 850 & 1222 & 24.3 & 8.0 & 312 & & 8.13 & & 590 \\
\hline 2600 & 1307 & & 0.9 & 337 & & 7.73 & 190 & \\
\hline \multicolumn{9}{|c|}{ 7/19/83 Well HTH-2 WL $555.7 \mathrm{ft}$} \\
\hline 504 & 1000 & 19.6 & 10.3 & 433 & & 7.50 & 650 & \\
\hline 950 & 1035 & 24.3 & 9.0 & 368 & & 7.88 & & \\
\hline \multicolumn{9}{|c|}{ 7/19/83 Well UC1P2SR WL $1116 \mathrm{ft}$} \\
\hline 1150 & 1500 & 22.9 & 7.6 & 250 & 227 & 9.43 & & 225 \\
\hline 1190 & 1549 & 24.1 & 8.0 & 253 & 248 & 9.43 & & 200 \\
\hline 1290 & 1620 & 24.7 & 10.4 & 264 & 259 & 9.63 & & 210 \\
\hline \multicolumn{9}{|l|}{$7 / 20 / 83$} \\
\hline 390 & 0936 & 24.6 & 10.4 & 257 & 263 & 9.63 & & 200 \\
\hline 490 & 1116 & 24.3 & 10.7 & 319 & 319 & 9.62 & & 215 \\
\hline 590 & 1134 & 25.1 & 10.0 & 363 & 331 & 9.61 & & 225 \\
\hline 690 & 1230 & 24.9 & 8.6 & 256 & 250 & 9.61 & 112 & 225 \\
\hline 790 & 1311 & 25.1 & 11.3 & 261 & 267 & 9.63 & & 215 \\
\hline 790 & 1334 & & 8.2 & 306 & 293 & 9.71 & 99 & \\
\hline 890 & 1431 & 25.0 & 10.9 & 296 & 286 & 9.62 & 100 & 215 \\
\hline 990 & 1500 & 25.8 & & 308 & 303 & 9.32 & & 240 \\
\hline 1090 & 1531 & 26.3 & 9.3 & 318 & 319 & 9.29 & & 240 \\
\hline 1090 & 1608 & & 8.2 & 340 & 319 & 9.30 & 144 & \\
\hline \multicolumn{9}{|c|}{$7 / 21 / 83$} \\
\hline 190 & 1627 & 25.4 & 10.5 & 242 & 269 & 9.10 & & 320 \\
\hline 290 & 1208 & 26.3 & 10.5 & 439 & 293 & 9.03 & & 350 \\
\hline 390 & 1253 & 26.4 & 11.6 & 281 & 281 & 9.10 & 124 & 350 \\
\hline 2390 & 1305 & & 7.2 & 228 & 262 & 9.10 & & \\
\hline 2490 & 1415 & 26.3 & 9.1 & 243 & 268 & 9.10 & & 340 \\
\hline 2590 & 1430 & 26.4 & 9.3 & 268 & 268 & 9.01 & & 300 \\
\hline 2590 & 1530 & & 7.3 & 268 & 268 & 9.12 & & \\
\hline
\end{tabular}

For the radionuclide analysis, a weighed aliquot of each sample was analyzed for tritium by liquid scintillation counting (LSC), using procedures that have been shown to yield satisfactory agreement with REECo analyses of UE2ce (RNM-2S) samples. The deepest Faultless sample $(2590 \mathrm{ft})$ was also given a long LSC count on a Beckman 9800 in the spectrum search mode, and the spectrum above the tritium region was compared with a background spectrum in an effort to find and identify any alpha or nontritium beta activity. A 500-lambda aliquot of each sample was flamed onto a stainless steel planchet and counted on an alpha spectrometry system designed and calibrated for the measurement of low levels of neptunium and plutonium. The filters through which the laboratory samples were passed were also used to filter the water retained from the field analyses (total combined volume filtered $\sim 6 \mathrm{~L}$ ) and were analyzed for gamma emitters using $\mathrm{Ge}(\mathrm{Li})$ detectors and the GAMANAL spectral analysis program. A 1-L Marinelli beaker containing filtered wa- ter from the $2590 \mathrm{ft}$ sample was also given a long count on a low-background, high-efficiency $\mathrm{Ge}(\mathrm{Li})$ system.

\subsubsection{Results}

Radiochemical. Tritium activities are summarized in Table 2-28.

The results of gamma analyses of all sample filters and the UC1P2SR $2590 \mathrm{ft}$ filtrate are summarized in Table 2-29. In general, no significant gamma activity was detected; as noted, the $2590 \mathrm{ft}$ filter appeared to contain ${ }^{125} \mathrm{Sb}$. We view these results with suspicion and consider sample or filter contamination in the laboratory to be the most plausible explanation.

Direct alpha spectrometry of small filtered sample aliquots detected no plutonium $(<0.005$ $\mathrm{pCi} / \mathrm{mL})$ or neptunium $(<0.01 \mathrm{pCi} / \mathrm{mL})$.

A long-count LSC spectral search on the $2590 \mathrm{ft}$ filtrate revealed no alpha activity or beta activity with energy greater than that of tritium (detection limit $\sim 0.5 \mathrm{pCi} / \mathrm{mL}$ ). 
Table 2-28. Faultless sample tritium activities.

\begin{tabular}{lcl}
\hline Sample & Depth (ft) & $\mu \mathrm{Ci} / \mathrm{mL}( \pm 2$ std dev \%) \\
\hline HTH-1 & 2600 & $<1.0 \times 10^{-6}$ \\
HTH-2 & 950 & $<1.0 \times 10^{-6}$ \\
UC1 & 1790 & $<1.0 \times 10^{-6}$ \\
UC1 & 2090 & $1.49 \times 10^{-5}(4.4 \%)$ \\
UC1 & 2390 & $2.04 \times 10^{-2}(0.5 \%)$ \\
UC1 & 2590 & $2.07 \times 10^{-2}(0.2 \%)$ \\
\hline
\end{tabular}

Table 2-29. Upper limits of Faultless sample gamma activity. (All activities are in $\mathrm{pCi} / \mathrm{mL}$.)

\begin{tabular}{lcc}
\hline Nuclide & Particulate $>0.45 \mu^{\mathrm{a}}$ & UC-1 $2590 \mathrm{ft}$ filtrate \\
\hline${ }^{7} \mathrm{Be}$ & $<8.0 \times 10^{-4}$ & \\
${ }^{40} \mathrm{~K}$ & $<1.1 \times 10^{-3}$ & \\
${ }^{54} \mathrm{Mn}$ & $<5.3 \times 10^{-5}$ & $<5.0 \times 10^{-4}$ \\
${ }^{60} \mathrm{Co}$ & $<5.3 \times 10^{-5}$ & $<4.9 \times 10^{-4}$ \\
${ }^{106} \mathrm{Ru}$ & $<4.4 \times 10^{-4}$ & $<5.1 \times 10^{-3}$ \\
${ }^{125} \mathrm{Sb}$ & $<1.2 \times 10^{-4}$ & $<1.6 \times 10^{-3}$ \\
${ }^{137} \mathrm{Cs}$ & $<9.4 \times 10^{-4}$ & $<5.6 \times 10^{-4}$ \\
${ }^{144} \mathrm{Ce}$ & $<3.4 \times 10^{-4}$ & \\
${ }^{238} \mathrm{U}$ & $<2.7 \times 10^{-3}$ & \\
${ }^{241} \mathrm{Am}$ & $<3.5 \times 10^{-4}$ & \\
\hline
\end{tabular}

a Except as noted below, all sample filters had nuclide upper limit values < blank filter values; reported values are for blanks.

b No identifiable peaks were observed; limits are based on $3 \times$ background std dev.

c UC1P2SR $2590 \mathrm{ft}$ filter showed $4.0 \times 10^{-4}( \pm 22 \%)$ $\mathrm{pCi} / \mathrm{mL}^{125} \mathrm{Sb}$. The value is suspect.
Chemical. Table 2.30 presents both field measurement results on the LLNL samples and the corresponding laboratory measurements on the pressurized samples returned to the laboratory. In addition to the dissolved oxygen in ppm, the ratio of the observed value to the saturation value at the temperature and altitude of the measurement is also reported. Measurements were made on unfiltered samples except for the laboratory alkalinity and conductivity measurements, which were made after filtering through a prefilter and a 0.45 $\mu \mathrm{m}$ Nuclepore filter. The laboratory alkalinity values are averages of one or more Hach titrator determinations and one or more $\mathrm{pH}$ titrations; there was no substantial or systematic difference between the results of the two methods. Sulfide was not detectable $(<0.1 \mathrm{ppm})$ in either field or laboratory-analyzed samples.

Table 2-31 gives the results of cation determination by ICP expressed as $\mathrm{mg} / \mathrm{L}$. Table 2-32 presents the results of anion analyses.

\subsubsection{Discussion}

The only radionuclide reliably detected at a significant level was tritium. The values and vertical distribution of ${ }^{3} \mathrm{H}$ were similar to the data previously reported by the USGS; however, the concentrations observed are modestly but significantly higher (10-15\%; decay corrections were not applied and would make the differences even

Table 2-30. Faultless sample field/laboratory measurements.

\begin{tabular}{|c|c|c|c|c|c|c|}
\hline & \multirow{2}{*}{$\begin{array}{l}\text { HTH-1 } \\
2600 \mathrm{ft}\end{array}$} & \multirow{2}{*}{$\begin{array}{c}\text { HTH-2 } \\
950 \mathrm{ft}\end{array}$} & \multicolumn{4}{|c|}{ UC1P2SR } \\
\hline & & & $1790 \mathrm{ft}$ & $2090 \mathrm{ft}$ & $2390 \mathrm{ft}$ & $2590 \mathrm{ft}$ \\
\hline \multicolumn{7}{|l|}{ Field samples ${ }^{a}$} \\
\hline $\mathrm{pH}$ & 7.73 & 7.88 & 9.71 & 9.30 & 9.10 & 9.01 \\
\hline Eh $\mathrm{mV}$ & 337 & 368 & 293 & 319 & 262 & 268 \\
\hline DO ppm & 0.84 & 8.4 & 7.6 & 7.6 & 6.7 & 6.8 \\
\hline DO/DO sat. & 0.13 & 1.26 & 1.14 & 1.17 & 1.03 & 1.05 \\
\hline Alk. ppm $\mathrm{CaCO}_{3}$ & 190 & - & 99 & 144 & 124 & - \\
\hline $\mathbf{S}^{=}$ & $\mathbf{N D}^{\mathbf{b}}$ & ND & ND & ND & ND & ND \\
\hline \multicolumn{7}{|l|}{ Lab samples } \\
\hline $\mathrm{pH}^{\mathrm{a}}$ & 7.75 & 7.90 & 9.09 & 8.86 & 8.75 & 8.91 \\
\hline Eh $\mathrm{mV}^{\mathrm{a}}$ & 235 & 356 & 319 & 305 & 264 & 255 \\
\hline DO ppm ${ }^{a}$ & 0.9 & 17.5 & 9.1 & 6.9 & 7.6 & 9.0 \\
\hline DO/DO sat. ${ }^{a}$ & 0.11 & 2.08 & 1.08 & 0.83 & 0.90 & 1.08 \\
\hline Alk. ppm $\mathrm{CaCO}_{3}{ }^{\mathrm{c}}$ & $196 \pm 5$ & $148 \pm 10$ & $87 \pm 2$ & $106 \pm 5$ & $118 \pm 6$ & $112 \pm 11$ \\
\hline Cond. $\mathrm{mho} / \mathrm{cm}^{\mathrm{c}}$ & 570 & 330 & 230 & 290 & 355 & 320 \\
\hline$S^{=}$ & ND & ND & ND & ND & ND & ND \\
\hline
\end{tabular}

\footnotetext{
a Unfiltered.

b ND: $\mathrm{S}=<0.1 \mathrm{ppm}$.

${ }^{c}$ Filtered, $0.45 \mu \mathrm{m}$.
} 
Table 2-31. Cation (ICP) analysis of Faultless samples made in the period of July 18-20, 1983.

\begin{tabular}{|c|c|c|c|c|c|c|c|}
\hline Element & $\begin{array}{c}\text { Detection } \\
\text { limit }\end{array}$ & НТН-1 & HTH-2 & F-1790 & F-2090 & F-2390 & $F-2590$ \\
\hline Aluminum & 0.008 & 0.028 & 0.029 & 0.029 & 0.100 & 0.059 & 0.051 \\
\hline Boron & 0.004 & 0.010 & 1.83 & 0.110 & 0.162 & 0.244 & 0.236 \\
\hline Cadmium & 0.002 & 0.004 & $<0.002$ & $<0.002$ & $<0.002$ & $<0.002$ & $<0.002$ \\
\hline Cobalt & 0.003 & 0.004 & $<0.003$ & $<0.003$ & $<0.003$ & $<0.003$ & $<0.003$ \\
\hline Copper & 0.002 & 0.031 & 0.012 & 0.011 & 0.005 & 0.029 & 0.003 \\
\hline Iron & 0.002 & 0.013 & 0.314 & 0.044 & 0.088 & 0.175 & 0.872 \\
\hline Lithium & 0.001 & 0.013 & 0.152 & 0.046 & 0.055 & 0.065 & 0.060 \\
\hline Manganese & 0.0003 & 0.040 & 0.047 & 0.007 & 0.013 & 0.058 & 0.020 \\
\hline Molybdenum & 0.004 & 0.019 & 0.101 & 0.074 & 0.138 & 0.043 & 0.040 \\
\hline Nickel & 0.008 & 0.023 & 0.009 & $<0.008$ & $<0.008$ & $<0.008$ & $<0.008$ \\
\hline Phosphorus & 0.042 & 0.142 & 0.139 & 0.074 & 0.124 & 0.139 & 0.112 \\
\hline Lead & 0.016 & 0.041 & 0.028 & 0.016 & 0.018 & 0.017 & 0.024 \\
\hline Selenium & 0.044 & 0.053 & 0.044 & $<0.044$ & 0.045 & 0.064 & 0.069 \\
\hline Silicon & 0.004 & 13.3 & 27.8 & 6.59 & 9.68 & 11.6 & 11.4 \\
\hline Strontium & 0.012 & 0.543 & 0.027 & 0.246 & 0.203 & 0.139 & 0.120 \\
\hline Uranium & 0.068 & 0.044 & $<0.00$ & $<0.068$ & $<0.068$ & $<0.068$ & $<0.068$ \\
\hline Vanadium & 0.003 & 0.005 & 0.007 & $<0.003$ & 0.007 & 0.024 & 0.019 \\
\hline Zinc & 0.001 & 0.110 & 0.109 & 0.045 & 0.027 & 0.257 & 0.073 \\
\hline Zirconium & 0.002 & $<0.002$ & 0.015 & $<0.002$ & $<0.002$ & $<0.002$ & 0.002 \\
\hline Calcium & 0.004 & 37.4 & 2.78 & 1.94 & 2.48 & 2.52 & 2.21 \\
\hline Potassium & 0.26 & 2.02 & 1.49 & 1.42 & 1.10 & 1.06 & 0.935 \\
\hline Magnesium & 0.0004 & 5.41 & 0.161 & 0.099 & 0.090 & 0.084 & 0.083 \\
\hline Sodium & 0.004 & 19.2 & 139 & 48.1 & 63.2 & 72.4 & 68.6 \\
\hline
\end{tabular}

Notes: Ignore all values less than the detection limit.

The detection limit is 4 times the standard deviation.

Results are in micrograms per milliliter (or ppm).

Table 2-32. Anion analyses of Faultless samples. (All values are in $\mathrm{mg} / \mathrm{L}$.)

\begin{tabular}{|c|c|c|c|c|c|c|c|}
\hline \multirow[b]{2}{*}{ Ion } & \multirow[b]{2}{*}{ Method ${ }^{\mathrm{a}}$} & \multirow[b]{2}{*}{ HTH-1 } & \multirow[b]{2}{*}{ HTH-2 } & \multicolumn{4}{|c|}{ UC1P2SR } \\
\hline & & & & $1790 \mathrm{ft}$ & $2090 \mathrm{ft}$ & $2390 \mathrm{ft}$ & $2590 \mathrm{ft}$ \\
\hline$\overline{F^{-}}$ & IC & 9.8 & $N D^{b}$ & 1.0 & 1.3 & 1.7 & 1.6 \\
\hline $\mathrm{Cl}^{-}$ & IC & 21.0 & 3.2 & 4.9 & 5.5 & 7.4 & 6.9 \\
\hline $\mathrm{NO}_{3}^{-}$ & IC & ND & ND & ND & ND & Trace & ND \\
\hline $\mathrm{SO}_{4}^{=}$ & I & 38.6 & 3.4 & 20.5 & 27.4 & 33.5 & 32.6 \\
\hline Alk ${ }^{c}$ & $\mathbf{A A}$ & 201 & 146 & 87 & 108 & 119 & 119 \\
\hline
\end{tabular}

a $\mathrm{IC}=$ ion chromatography; uncertainties $< \pm 1.5 \% . \mathrm{AA}=$ autoanalyzer.

b Not detectable.

c Alk is carbonate alkalinity $\left(\mathrm{HCO}_{3}^{-}+\mathrm{CO}_{3}^{-}\right)$expressed as $\mathrm{mg} / \mathrm{L} \mathrm{CaCO}, \pm 3 \mathrm{mg} / \mathrm{L}$.

larger) than the 1981 USGS results..$^{37}$ It remains to be seen whether this is a systematic interlaboratory difference or whether the tritium values have actually increased. If the increase is real, it has interesting implications in terms of the relationship of the sampling points to the source and the movement of tritiated water (HTO).

Although the counting methods used were relatively insensitive compared with sample concentration or radiochemical separation techniques, no credible evidence of other radioactivity was found. The small ${ }^{125} \mathrm{Sb}$ activity indicated for one of the filters is suspect. If the apparent increase in
${ }^{3} \mathrm{H}$ activity proves to be real, it may be desirable at some time in the future to perform more sensitive analyses for some of the mobile fission products.

The laboratory alkalinity determinations (Hach titrator, $\mathrm{pH}$ titration, and autoanalyzer) are in close agreement and consistent with earlier USGS profiles, as are the conductivity data. ${ }^{37}$ Comparison of filtered and unfiltered alkalinity data suggests that the two shallower UC1P2SR samples may have contained some particulate carbonate or other titratable base $(\max \sim 40 \mathrm{ppm}$ at $2090 \mathrm{ft}$ ). Agreement between LLNL cation and anion results and the 1981 USGS data is reasonable; 
in general, it appears that the analytical results obtained by the two laboratories are satisfactorily comparable.

Except for the possible shift in tritium activity discussed above, the only other significant change from the earlier results was an increase in $\mathrm{pH}$ (relative to the 1982 USGS results) of $0.2-0.4$ in the depth interval below $2100 \mathrm{ft}$. Temperatures were consistent with 1982 data, although lower than in earlier samplings.

Depth profiles of the measured parameters remained qualitatively consistent with earlier observations, with different but internally consistent regions above $1900 \mathrm{ft}$ and below $2100 \mathrm{ft}$ and transitional values in between. This may relate to the drilling report of loss of circulation at $1979 \mathrm{ft}$, and it suggests different hydrologic regimes above and below this depth.

The data, in conjunction with USGS data from earlier samples, suggest that the upper and lower zones have distinctly different chemical signatures that are reasonably consistent over time and depth. It is interesting to note that HTH-1 and HTH-2 have chemical characteristics that are distinctly different both from each other and from both of the zones observed in UC1P2SR. Prior to 1982 , there was a marked thermal gradient in the lower region of UC1P2SR (USGS data previously distributed); this appears to have disappeared rather abruptly. Figure 2-9 shows the history of observed temperatures at $2590 \mathrm{ft}$.

In addition to the hydrologic implications of the four different geochemical regimes sampled in the three wells, three interesting points are raised by the secular changes observed in UC1P2SR:

1. The abrupt change in thermal gradient near the bottom (see Fig. 2-9) is not characteristic of a static cooling curve and probably represents

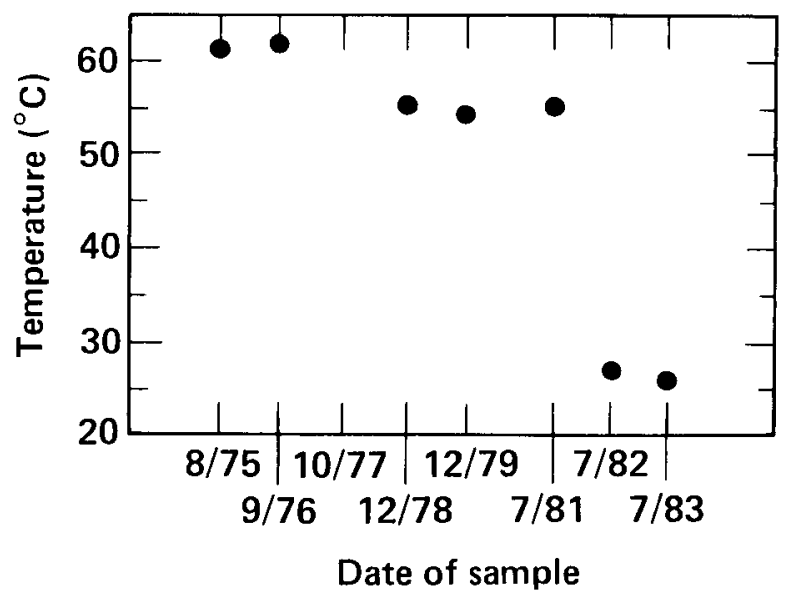

Figure 2-9. Observed temperatures at $2590 \mathrm{ft}$ at UC1P2SR (Faultless site).

the combined effects of the heat source and the ground-water flow regime.

2. The shift in $\mathrm{pH}$ in the lower zone is hard to evaluate. Since the $\mathrm{pH}$ increase was noted between 1982 and 1983 and the temperature dropped prior to 1982 , temperature effects on the chemical equilibria cannot readily account for the shift unless the rate of equilibration is very slow.

3 . If the apparent increase in tritium concentrations is real, it suggests migration of higher activity water toward the bottom of the well and indicates that it might be useful to sample for other radionuclides.

In view of the data record and the observed changes in the well water characteristics, it seems appropriate to initiate a review and interpretation of the results obtained to date before resampling this system. 


\subsection{References}

1. Jennings, C. D., and M. Mount, 1983, Northern Marshall Islands Radiological Survey: A Quality Control Report, Lawrence Livermore National Laboratory, Livermore, CA, UCRL-52853, Part 5.

2. Douthett, E. M., 1980, "Radionuclide Migration Committee Meeting," DOE memorandum dated October 31, 1980.

3. Smith, B. P., 1983, "Sample Results from U20n," REECo Letter Report to T. M. Humphrey, DOENVO, dated December 7, 1983.

4. Ramspott, L. D., 1978, "Annual Report for FY 77 for LLL Participation in ERDA-NV project: Radionuclide Migration in the Ground," LLL Letter Report NM \#78-4, dated April 4, 1978.

5. Hoffman, D. C., 1977, "Summary of RNM Activities during FY-76 and FY-77-July 1, 1976 to September 30, 1977," LASL Letter Report to R. W. Newman dated November 10, 1977.

6. Daniels, W. R., Ed., 1981, Laboratory and Field Studies Related to the Radionuclide Migration Project, Annual Report, October 1, 1979-September 30, 1980, Los Alamos National Laboratory, Los Alamos, NM, Report LA-8670-PR.

7. Daniels, W. R., Ed., 1982, Laboratory and Field Studies Related to the Radionuclide Migration Project, Annual Report, October 1, 1980-September 30, 1981, Los Alamos National Laboratory, Los Alamos, NM, Report LA-9192-PR.

8. Daniels, W. R., Ed., Laboratory and Field Studies Related to the Radionuclide Migration Project, Annual Report, October 1, 1981-September 30, 1982, Los Alamos National Laboratory, Los Alamos, NM, Report LA-9691-PR.

9. Daniels, W. R., Ed., Laboratory and Field Studies Related to the Radionuclide Migration Project, Annual Report, October 1, 1983-September 30, 1983, Los Alamos National Laboratory, Los Alamos, NM, Report LA-10121-PR.

10. Hoffman, D. C., R. Stone, and W. W. Dudley, Jr., 1977, Radioactivity in the Underground Environment of the Cambric Nuclear Explosion at the Nevada Test Site, Los Alamos Scientific Laboratory, Report LA-6877-MS (July 1977).

11. Ramspott, L, and I. Borg, 1977, Underground Nuclear Tests Below the Water Table as Waste Disposal Pilot Plants, Geological Society of America Annual Meeting, Symposium on Hydrogeology of Radioactive Waste Disposal (Seattle, WA, Nov. 7-9, 1977). Lawrence Livermore National Laboratory, Livermore, CA, UCRL-79632.

12. Ramspott, L., J. Tewhey, D. Coles, H. Weed, J. Schweiger, and R. Stone, 1979, FY-78 Annual Technical Report of Lawrence Livermore National Laboratory's Participation in the DOE-NV Project: Radionuclide Migration in the Ground, Lawrence Livermore National Laboratory, Livermore, CA, UCID-18259.

13. Wolfsberg, K., 1978, Sorption-Desorption Studies of Nevada Test Site Alluvium and Leaching Studies of Nuclear Test Debris, Los Alamos Scientific Laboratory, Los Alamos, NM, Report LA-7216-MS.

14. Wolfsberg, K., B. P. Bayhurst, B. M. Crowe, W. R. Daniels, B. R. Erdal, F. O. Lawrence, E. A. Norris, and J. R. Smyth, 1979, Sorption-Desorption Studies on Tuff. I. Initial Studies with Samples from the J-13 Drill Site, Jackass Flats, Nevada, Los Alamos Scientific Laboratory, Los Alamos, NM, Report LA-7480MS.

15. Coles, D., and L. Ramspott, 1982, "Migration of Ruthenium-106 in a Nevada Test Site Aquifer: Discrepancy Between Field and Laboratory Results," Science 215, pp. 1235-1237.

16. Daniels, W. R., D. C. Hoffman, B. R. Erdal, and K. Wolfsberg, 1978, "A Radionuclide Migration Study at the Nevada Test Site," (abs.), EOS, Trans. Am. Geophys. Union 59, 1224.

17. Erdal, B. R., W. R. Daniels, D. C. Hoffman, F. O. Lawrence, and K. Wolfsberg, 1979, "Sorption and Migration of Radionuclides in Geologic Media," in Scientific Basis for Nuclear Waste Management 1, G. J. McCarthy, Ed., Plenum, New York, NY, p. 423.

18. Hoffman, D. C., 1979, "A Field Study of Radionuclide Migration," in Radioactive Waste in Geologic Storage, S. Fried, Ed., ACS Symposium Series, No. 100, p. 149.

19. Hoffman, D. C., and W. R. Daniels, 1984, "Assessment of the Potential for Radionuclide Migration from a Nuclear Explosion Cavity," in Groundwater Contamination, National Research Council, National Academy Press, Washington, D.C., pp. 139-146.

20. Wolfsberg, K., W. R. Daniels, B. R. Erdal, and D. C. Hoffman, 1980, "Migration of Radionuclides in Geologic Media-Laboratory and Field Studies," in Effluent and Environmental Radiation Surveillance, J. J. Kelly, Ed., Am. Soc. for Testing and Materials, ASTM STP 698, p. 252. 
21. Pawlowski, G., 1982, Results from Exploratory Drill Hole UE2ce Northwest Yucca Flat, Nevada Test Site, Near the Nash Event, Lawrence Livermore National Laboratory, Livermore, CA, UCID-19324.

22. Goebel, T. E., 1976, "Site Preparation and Drilling Program: UE-2ce," Fenix and Scisson, Inc., Mercury, Nevada.

23. Jacobson, R., 1984, Desert Research Institute, Reno, NV, personal communication.

24. Hoffman, D. C., 1978, "Analysis of Water Samples from UE2ce," Los Alamos National Laboratory, Los Alamos, NM, Letter Report to T. M. Humphrey \& RNM Distribution.

25. Daniels, W. R., 1978, "Analysis of Water Samples from UE2ce," Los Alamos National Laboratory, Los Alamos, NM, Letter Report to T. M. Humphrey \& RNM Distribution.

26. Daniels, W. R., 1978, " ${ }^{90} \mathrm{Sr}$ and ${ }^{137} \mathrm{Cs}$ Analyses of Water from UE2ce," Los Alamos National Laboratory, Los Alamos, NM, Letter Report to T. M. Humphrey \& RNM Distribution.

27. Daniels, W. R., 1983, Laboratory and Field Studies Related to the Radionuclide Migration Project, October 1, 1981-September 30, 1982, Los Alamos National Laboratory, Los Almos, NM, Progress Report, LA-9691-PR.

28. Daniels, W. R., and J. L. Thompson, 1984, Laboratory and Field Studies Related to the Radionuclide Migration Project, October 1, 1982-September 30, 1983, Los Alamos National Laboratory, Los Alamos, NM, Progress Report, LA-10121-PR.

29. Garber, M. S., 1971, "Hydraulic Test and Quality-of-Water Data from Hole U3cnPS\#2, Bilby Site, Nevada Test Site." USGS Technical Letter NTS-230.

30. Garber, M. S., and R. H. Johnston, 1967, "A Summary of the Lithographic Data, Aquifer Tests and Construction of Hydraulic Test Well U3cn-5, NTS." USGS Technical Letter NTS-200, dated September $15,1967$.

31. Beetem, W. A., C. G. Angelo, and B. P. Robinson, 1965, "Quality of Water Studies at the Bilby Site," USGS Technical Letter NTS-113.

32. Hoffman, D. C., 1977, "T analysis of U3cnPS\#2," Los Alamos National Laboratory, Los Alamos, NM, Letter Report.

33. Coogan, J. S., 1982, USEPA/EMSL letter to N. Crow, Lawrence Livermore National Laboratory, Livermore, CA, with attached computer data base printout for U3cn-5.

34. Claassen, H. C., 1979, Letter from United States Geological Survey (Lakewood, CO) to E. M. Douthett, DOE-NVOO, dated September 9, 1979.

35. Wagoner, J. L., and L. D. Ramspott, 1981, Results of Exploratory Drill Hole UE7ns, East-Central Yucca Flat, Nevada Test Site, Lawrence Livermore National Laboratory, Livermore, CA, UCID-19879.

36. U.S. Environmental Protection Agency, Las Vegas, NV, June 30, 1982, "Water Results," Internal Letter Report.

37. Thordarson, W., 1984, "Hydrologic Monitoring at the Faultless Site, Nye County, Nevada." U.S. Geological Survey Open File Report 84-580, United States Geological Survey, Denver, CO. 


\section{Methodological Investigations}

\subsection{The Phantom Europium Migration}

(Contributors: R. C. Evans, K. V. Marsh, R. W. Buddemeier, and J. Rego)

${ }^{155} \mathrm{Eu}$ is a reasonably abundant fission product (fission yield $\sim 0.03 \%$ ) with a 4.7 -y half-life. It is known to occur as a persistent component of detonation cavity and surface contamination activity at the NTS. Gamma spectral analysis of large-volume evaporated water samples from two satellite wells (Nash and Bilby) consistently yielded indications of low levels (tenths to hundredths of $\mathrm{dpm} / \mathrm{L}$ ) of ${ }^{155} \mathrm{Eu}$. In the case of the Nash satellite, other radionuclides were also observed (see Section 2.4). This suggestion of europium mobility was further supported by the results of an unrelated study of radionuclides in the soil column below an abandoned disposal site at LLNL, where tritium and ${ }^{155} \mathrm{Eu}$ appeared to occur at penetration depths greater than those observed for other nuclides. ${ }^{1}$ Because there were no literature reports of or obvious geochemical reasons for such environmental europium mobility, we set out to verify or disprove its presence by three concurrent approaches: (1) recounts of several archived samples that had initially been measured nearly one ${ }^{155} \mathrm{Eu}$ half-life ago; (2) a careful review of possible interferences at the ${ }^{155} \mathrm{Eu}$ gamma-ray energies and the calculational procedures used by the GAMANAL computer code to identify and quantify ${ }^{155} \mathrm{Eu}$, and (3) redissolution of an NTS groundwater salt sample (Nash satellite well, April 18, 1984) that had yielded an apparent ${ }^{155} \mathrm{Eu}$ value by bulk gamma spectroscopy, followed by radiochemical separation for europium and measurement of the yield-corrected activity of the purified sample.

1. The recounted samples yielded apparent activities comparable to the initial determinations. Although these results were not absolutely conclusive because of relatively large statistical uncertainties and some variation in the peak ratios of the gamma rays, they did not show the decrease to be expected from ${ }^{155} \mathrm{Eu}$ decay.

2. The calculational library used for our GAMANAL runs identifies ${ }^{155} \mathrm{Eu}$ from two or three of the following gamma energies: $105.3 \mathrm{keV}$ $(22.8 \%), 86.6 \mathrm{keV}(32.2 \%)$, and $60.01 \mathrm{keV}(1.32 \%)$. At the very low apparent counting rates observed, the $60-\mathrm{keV}$ peak is not above background, so 86.6 and 105.3 are the primary energies used for ${ }^{155} \mathrm{Eu}$ measurement. Both of these are subject to interferences. The region around the $86.6-\mathrm{keV}$ peak is generally complicated by lead $x$ rays generated in the detector shield, and by lead and bismuth $x$ rays from the natural decay series elements in the sample. The $105.3-\mathrm{keV}$ peak overlaps the $105-\mathrm{keV}$ thorium $x$ ray. To calculate the disintegration rate of a nuclide, GAMANAL utilizes a leastsquares weighted average of as many nuclear gamma rays as possible. $X$ rays are not included in the calculations because their absolute intensities are not constant; thus, they are "left over" and may be mistaken for gamma rays from other nuclides if they are similar in energy. Consequently, the $105-\mathrm{keV} x$ rays from thorium could be interpreted as resulting from a gamma ray from ${ }^{155} \mathrm{Eu}$. A similar argument applies to the $86.6-\mathrm{keV}$ peak, and the presence of both peaks in a spectrum may satisfy the GAMANAL requirements for detection of ${ }^{155} \mathrm{Eu}$, at least with a relatively large error and low probability. We examined the spectra and compared the ratios of the various europium and thorium peaks, but could find no consistently convincing evidence to prove or disprove the presence of ${ }^{155} \mathrm{Eu}$.

3. The salt analyzed was an 88.8-g aliquot of the April 18, 1984 Nash satellite sample, which originally showed an apparent ${ }^{155} \mathrm{Eu}$ concentration of $0.38 \mathrm{dpm} / \mathrm{L}$ by bulk gamma count. The sample was dissolved in dilute $\mathrm{HCl}$, and a known amount of stable europium carrier was added. $\mathrm{EuF}_{3}$ was precipitated with $\mathrm{HF}$ and redissolved with boric acid and nitric acid. The hydroxide was then precipitated with $\mathrm{NH}_{4} \mathrm{OH}$, washed, and redissolved in $8 M$ nitric acid. This solution was passed through a preconditioned Dowex AG1-X8 column (50-100 mesh), then eluted with $8 M$ nitric acid. This step elutes the europium, but leaves thorium on the column. After this separation, the europium was again precipitated as the hydroxide, washed, redissolved in $\mathrm{HCl}$, and finally reprecipitated as the oxalate. After washing and drying, the europium oxalate was ignited and weighed as $\mathrm{Eu}_{2} \mathrm{O}_{3}$ to determine yield and the oxide sample was gamma counted. Separation of the thorium as well as radium and its daughters eliminated the major possible interferences. Because of the greatly improved counting geometry and reduced total sample activity, a much lower detection limit for ${ }^{155} \mathrm{Eu}$ was achieved. 
The purified sample, when recounted on our low-background $\mathrm{Ge}(\mathrm{Li})$ system, yielded no discernable peaks indicative of either thorium or europium. The chemical europium yield was $33 \%$. Based on this and the detector calibration and background data, we calculate that the ${ }^{155} \mathrm{Eu}$ concentration in the original water sample must have been less than $0.0035 \mathrm{dpm} / \mathrm{L}$. Compared with an original bulk salt determination of $0.38 \mathrm{dpm} / \mathrm{L}$, this result indicates that essentially all of the apparent ${ }^{155} \mathrm{Eu}$ activity was in fact caused by interfering photons, probably dominated by the thorium $x$ ray.

It should be noted also that all of the samples that showed apparent europium activities were either soils or ground waters that had probably interacted with the Paleozoic carbonate aquifer at NTS. Although thorium analyses are not available, it is possible that these samples might have higher natural thorium concentrations than the groundwater samples from tuffaceous and alluvial aquifers, which did not show apparent europium activities. We conclude that direct gamma spectrometry measurements of low levels of ${ }^{155} \mathrm{Eu}$ in environmental samples are unreliable unless a confirming radiochemical separation is performed, all three of the europium gammas are observed with appropriate intensity ratios, or a half-life measurement is performed.

\subsection{Pressurized Sample Integrity}

(Contributors: R. W. Buddemeier, J. Rego, and J. Schweiger)

During July 1983, a joint sampling effort was conducted at the Faultless Event site (Central Nevada Test Area) by the USGS, EPA, and LLNL personnel. UC1P2SR and two satellite wells, HTH-1 and $\mathrm{HTH}-2$, were sampled; the results of the chemical and radiochemical analyses are reported in Section 2.7. Field and laboratory observations caused us to review and investigate the performance of the pressurized "thief" samplers used for down-hole sampling in wells not equipped with pumps. The results are reported below.

\subsubsection{Sampling}

Two similar types of down-hole samplers were used, both made of stainless steel with $\mathrm{O}$ ring sealed couplings. The USGS 6-L sampler, which featured an electromechanically activated valve, was used to take top and bottom samples in the satellite wells and a vertical profile in the
Faultless well. The sampler was closed at the surface, attached to the valve-actuating mechanism on the end of the cable, lowered to the desired depth, and then opened and closed to collect the sample. The samplers used by LLNL consisted of two 1.5-L USGS barrels coupled together with a similar valve head at the upper end. The bottom of both barrels and the top of the lower one were fitted with manual valves. In use, the sampler was sent down after evacuation with the two middle valves open and the top (electromechanical) and bottom valves closed. This sampler was used on a second run at preselected depths (based on previous chemical and radiochemical data) after the USGS sample was taken. For the LLNL samples, the sampler was evacuated at the surface to a pressure of 0.1-0.2 Torr using a Welsh Duo-Seal pump, closed, and then opened and reclosed at the desired sampling depth. Prior to use, the evacuated sampler was left connected to the vacuum manifold for 30-60 min with the pump valved off to check for leaks; no measurable pressure increase was observed. All samplers were lowered and activated with the calibrated cable on the EPA field van.

The USGS sampler was opened after retrieval and decanted into a large stainless steel container from which aliquots were taken for the various field and subsequent laboratory analyses. The internal valves on the two separate component barrels of the LLNL sampling assembly were closed before the barrels were decoupled, and one sealed barrel from each sample was shipped back to LLNL for analysis. The second barrel of each pair was sampled in the field by attaching a hose barb fitting to one end and slowly opening top and bottom valves to allow the water to flow out. Efforts were made to minimize exposure to the atmosphere of those sample aliquots intended for redox-sensitive measurements by avoiding the first and last samples, keeping the drain tube full and the flow rate slow, etc. However, field observations indicated that most of the samples taken with the evacuated samplers were pressurized and effervescent on decanting, and showed levels of dissolved oxygen (DO) comparable to the samples taken without evacuation of the sampler.

\subsubsection{Laboratory Procedures}

At LLNL, the sealed, pressurized sample barrels were drained in essentially the same fashion as in the field; however, because the field samples were effervescent and showed oxygen supersaturation, a system was developed to sample the pressurized gas from the barrels before sampling 
the water. A vacuum-tight hose barb fitting was attached to the upper end of the barrel, and to that was attached a four-way connector with a vacuum gauge, a mass spectrometry gas sample tube, and a valved connection to a laboratory vacuum pump. This system was pumped down, valved off from the pump, and checked for leaks. The upper sampler barrel valve was opened. Pressure in the attached manifold was recorded, and the gas sample tube was closed, removed, and submitted for analysis. The water samples were then decanted and promptly analyzed for $\mathrm{O}_{2}, \mathrm{Eh}$, $\mathrm{pH}$, and sulfide to investigate the effects of storage in the pressurized barrels; Eh and dissolved oxygen were followed as a function of time after decanting in one of the samples.

\subsubsection{Results}

Analytical results are tabulated in detail in Section 2.7. As mentioned above, the field samples were generally effervescent, and with the exception of $\mathrm{HTH}-1$, gave dissolved oxygen readings in excess of the local saturation value (see Table 2-30). On the basis of rather crude pressure-volume estimates, the four UC1P2SR samples all released 10-15 cc of gas when vented into the evacuated sample tubes. The results of mass spectrometric analysis of these gas samples (on a water free volume \% basis) are given in Table 3-1, which also includes the standard composition of dry air for comparison.

The laboratory samples were also effervescent (again with the exception of HTH-1) when decanted, and showed values at or near oxygen saturation (Table 2-30). After the initial measurements of oxygen and Eh, the HTH-2 lab sample was shaken vigorously and remeasured; DO decreased from the original 17.5 to $11.4 \mathrm{ppm}$, and Eh dropped from 356 to $155 \mathrm{mV}$. The same sample was then purged for 2 min with argon gas, after which the DO dropped to $3.7 \mathrm{ppm}$ and the Eh to $117 \mathrm{mV}$.

These results indicate that, at atmospheric pressure, all but one of the samples taken with the

Table 3-1. Composition (vol\%) of gas from pressurized samples of UC1P2SR.

\begin{tabular}{lccccr}
\hline Gas & $1790 \mathrm{ft}$ & $2090 \mathrm{ft}$ & $2390 \mathrm{ft}$ & $2590 \mathrm{ft}$ & Air \\
\hline $\mathrm{N}_{2}$ & 84.09 & 81.26 & 85.17 & 85.46 & 78.09 \\
$\mathrm{O}_{2}$ & 14.82 & 17.72 & 13.78 & 13.51 & 20.95 \\
$\mathrm{Ar}$ & 1.068 & 0.974 & 1.03 & 1.004 & 0.93 \\
$\mathrm{CO}_{2}$ & 0.020 & 0.039 & 0.02 & 0.023 & 0.03 \\
\hline
\end{tabular}

"evacuated" samplers was supersaturated with a gas having a composition closely approximating that of air. The fact that the oxygen content of the gas is reduced relative to that of air may suggest that some of the introduced oxygen reacted with the sample; if this was the case, it would imply that the original sample contained chemical species that were reduced relative to equilibrium with the atmosphere. The correlation of DO with Eh described in the preceding paragraph suggests that observed Eh values may be affected by the oxygen gas dissolved in the water.

\subsubsection{Discussion}

When an air-filled sampler is opened at a depth significantly below the water surface, the hydrostatic pressure forces all or most of the gas into solution. When the containing pressure is released at the surface, the solution is supersaturated and effervesces. Because there is no credible mechanism for producing ground waters naturally supersaturated with nitrogen and argon, we are forced to conclude that the gases observed were contaminants carried down with the sampler and injected in situ. There are two possible mechanisms by which this may have happened: (1) The leak test used in the field did not detach the samplers from the evacuated manifold, so it did not verify that the upper valve was leak-free at atmospheric pressure, and (2) an air bubble may have been trapped in the electromechanical valveactuating head on the cable.

Based on the volumes of gas collected, the measured concentrations, and the assumption that the HTH-1 sample represents uncontaminated ground-water conditions, each of the samples except HTH-1 must have contained a minimum (since we have no estimate of gas volume lost by effervescence between depressurization and DO measurement) of $\geq 100 \mathrm{cc}$ of air. In a 3 -L sampler, this corresponds to a pressure on the order of $0.05 \mathrm{~atm}(\sim 40$ Torr $)$.

Although the data presented in Section 2.7 (other than those for DO and Eh) are unlikey to be affected by this contamination, the chemical implications of this exposure are significant in terms of the potential uses of these samplers. The data of Table 3-1 suggest that something like $25 \%$ of the oxygen in the original air may have reacted with the sample or sampler; this would correspond to about $5 \mathrm{cc}$, or $0.2 \mathrm{mmol}$. This is ample to destroy any redox-sensitive equilibria in the system, because all of the reducible species are present at less than millimolar concentrations (see Table 2-23). In addition to affecting any direct 
measurements of redox speciation, this sample alteration could potentially affect the distribution of trace elements between dissolved and particulate phases in cases where different oxidation states have radically different solubilities or sorption characteristics.

The effect of the carbon dioxide in the included air can also be estimated; the amount available would be a few $\mu \mathrm{mol}$. Because these samples contained bicarbonate/carbonate concentrations at the mmol level, they would be relatively well buffered and micromoles of carbon dioxide would probably have a negligible effect on either $\mathrm{pH}$ or carbonate system concentrations. This would not necessarily always be the case, however; if a poorly buffered water were sampled with an air-filled sampler, $\mathrm{pH}$ perturbations would be possible. The data presented in Table 3-1 and Section 2.7 also suggest that no significant loss of $\mathrm{CO}_{2}$ occurred by degassing or gas purging, because the evolved gas $\mathrm{CO}_{2}$ concentrations did not differ significantly from those of air. The $\mathrm{pH}$ of the Faultless samples was high enough so that essentially no undissociated aqueous carbon dioxide or carbonic acid should have been present.

Dissolved oxygen and sulfide can both be measured reliably at the $0.1-\mathrm{ppm}$ level. For these measurements to be significant, the sample would have to contain considerably less than $1 \mathrm{cc} / \mathrm{L}$ of introduced air, which implies the ability to evacuate and maintain the entire sampler assembly at a final pressure of less than $0.001 \mathrm{~atm}$ with reasonable confidence.

\subsection{Filtration Studies}

\section{(Contributors: R. W. Buddemeier and J. Rego)}

The question of appropriate filtration procedures for RNM ground-water samples is a vexing one. Noted below are four of the issues that need to be considered:

1. Intercomparison of samples. Most geochemists report analytical data for samples that have been filtered through $0.45-$ or $0.2-\mu \mathrm{m}$ filters. There is no standardized procedure for environmental radioactivity studies, and a review of past analyses of RNM well samples shows that various practices have been followed.

2 . Interpretation of results. The nuclides of greatest interest from the standpoint of migration potential are those present in dissolved form; inclusion of particulate activity in this category results in an overestimate of the activity available for migration. On the other hand, small colloidal particles may be transported by ground-water flow, and any strongly sorbed species associated with such particles would therefore be more mobile than models based solely on solution chemistry would indicate.

3. Equilibrium. If the sample collected is for any reason not fully equilibrated between dissolved and sorbed fractions, or if chemical changes occur between sampling and analysis that affect the solution-solid equilibrium, the activities measured will be a function of time and any chemical changes in the sample may not represent the true in situ conditions.

4. Sample integrity. Field filtration is tedious and increases the likelihood of sample contamination, while laboratory filtration may undersample the particulate fraction (because of settling in the storage container) and, as noted above, may yield results representing postsampling processes rather than the original conditions.

LLNL large-volume samples have generally been either unfiltered or filtered through a $1.0-\mu \mathrm{m}$ cartridge filter (see Section 2.1.1). The results to date have not yielded evidence of any significant difference between these two methods. During 1983 and 1984, we experimented with various filtration methods. Our initial efforts made use of $0.45-\mu \mathrm{m}$ Nuclepore filters, but results were unsatisfactory. In addition to operational inconvenience caused by the use of low-capacity filters, we consistently observed high blank values for unused filters; in most cases involving satellite well samples, the blank was considerably higher in activity than the actual sample filters.

A LANL study of the Nuclepore filters has shown that they contain measurable amounts of a number of radionuclides, and that at least some of this activity is washed out into the filtrate at time of use. ${ }^{2}$ This makes them particularly inappropriate for use with low-level samples.

We have subsequently switched to bag-type filters (Fin-L-Filters, a hydrophilic terpolymer formulation supplied by Cole-Parmer), which are used in a standard cartridge-type filter holder. Available in $0.45-$ and $0.2-\mu \mathrm{m}$ nominal sizes, as well as a felt prefilter, they have low activity blanks (see below) and a higher capacity and throughput than the Nuclepores. Although initial results seem satisfactory, we are continuing our evaluation.

In an effort to assess the amount of activity associated with very small $(<0.2-\mu \mathrm{m})$ particles, we have initated a series of studies using a commercially available (Millipore) ultrafiltration system. This system passes the feed solution across a 
series of very fine membrane filters under pressure; the filtrate is collected and the flow system recycles the retentate into the feed stock. The retentate (feed) solution may be reduced to a volume limited only by the volume of the flow system by use of a continuous-flow recycling process. Membrane filter cartridges are available with nominal ratings of $100,000,10,000$, and 1,000 molecular weight units (MWU). To date, we have used the 100,000 MWU membrane, which has an equivalent pore size rating of approximately $0.006 \mu \mathrm{m}$.

Two experiments have been performed, both using water samples from the Cheshire chimney well (U20n-see Section 2.2 for a discussion of the Cheshire system). This water has radionuclide levels high enough to provide good analytical sensitivity for investigations of the distribution between different fractions. The first sample analyzed was a composite sample consisting of $2-\mathrm{L}$ samples taken at corrected flowmeter readings of $81,370,96,660,107,125,120,425$, and 130,480 gal and a 19-L sample taken at a corrected flowmeter reading of $71,603 \mathrm{gal}$. All of these samples were field filtered through the same multiple $0.45-\mu \mathrm{m}$ filter assembly. After a 1-L aliqout of the 19-L sample was gamma counted in a Marinelli beaker, the samples were combined to yield a single $28-\mathrm{L}$ composite, which was then further processed through the Millipore ultrafiltration unit rated at approximately $0.006 \mu \mathrm{m}$. The retentate $(\sim 140 \mathrm{~mL})$ was evaporated to dryness and gamma counted, and the filtrate was recounted in the Marinelli beaker system. Table 3-2 presents the results, expressed in units of dpm/L of composite solution, for the gamma analyses of these samples.

We also analyzed by our standard laboratory procedures a 200-L sample taken at a corrected flowmeter reading of 131,860 gal. This sample was filtered through a prefilter and $0.45-\mu \mathrm{m}$ filter in the laboratory and then evaporated to dryness. The resulting salt sample was homogenized and gamma counted (see Section 2.2). Table 3-3 summarizes the total, filtrate, and particulate $(>0.45-\mu \mathrm{m})$ activities expressed as $\mathrm{dpm} / \mathrm{L}$.

Because the small volumes analyzed for the composite sample made the analyses relatively insensitive for the less abundant nuclides, a second

Table 3-2. Analyses of U20n 28-L composite sample calculated to day 253.5 (1983). Units are dpm/L ( \pm 1 std dev \%).

\begin{tabular}{|c|c|c|c|c|}
\hline Nuclide & $\begin{array}{c}\text { Filters } \\
(0.45 \mu \mathrm{m})\end{array}$ & $\begin{array}{l}\text { Ultrafilter } \\
\text { retentate }\end{array}$ & Ultrafiltrate & Total \\
\hline${ }^{22} \mathrm{Na}$ & $\begin{array}{l}0.92 \\
(31 \%)\end{array}$ & - & $\begin{array}{l}2.86 \\
(26 \%)\end{array}$ & 3.8 \\
\hline${ }^{40} \mathrm{~K}$ & - & $\begin{array}{l}0.84 \\
(33 \%)\end{array}$ & - & 0.8 \\
\hline${ }^{54} \mathbf{M n}$ & $\begin{array}{l}0.87 \\
(16 \%)\end{array}$ & $<0.01$ & $<0.9$ & $\sim 0.9$ \\
\hline${ }^{60} \mathrm{Co}$ & $\begin{array}{l}7.27 \\
(3 \%)\end{array}$ & $\begin{array}{l}0.05 \\
(27 \%)\end{array}$ & $<0.9$ & $\sim 7.3$ \\
\hline${ }^{106} \mathbf{R u}$ & $\begin{array}{l}218 \\
(1 \%)\end{array}$ & $\begin{array}{l}3.62 \\
(9 \%)\end{array}$ & $<21.3$ & $\sim 222$ \\
\hline${ }^{125} \mathrm{Sb}$ & $\begin{array}{l}79.1 \\
(2 \%)\end{array}$ & $\begin{array}{l}17.2 \\
(2 \%)\end{array}$ & $\begin{array}{l}1709 \\
(4 \%)\end{array}$ & 1805 \\
\hline${ }^{134} \mathrm{Cs}$ & $\begin{array}{l}1.87 \\
(8 \%)\end{array}$ & $\begin{array}{l}0.07 \\
(31 \%)\end{array}$ & $\begin{array}{l}2.44 \\
(22 \%)\end{array}$ & 4.4 \\
\hline${ }^{137} \mathrm{Cs}$ & $\begin{array}{l}3555 \\
(1 \%)\end{array}$ & $\begin{array}{l}95.5 \\
(5 \%)\end{array}$ & $\begin{array}{l}3596 \\
(2 \%)\end{array}$ & 7151 \\
\hline${ }^{144} \mathrm{Ce}$ & $\begin{array}{l}46.8 \\
(5 \%)\end{array}$ & $\begin{array}{l}1.27 \\
(15 \%)\end{array}$ & - & $\sim 48.1$ \\
\hline${ }^{152} \mathrm{Eu}$ & $\begin{array}{l}23.2 \\
(2 \%)\end{array}$ & $\begin{array}{l}0.58 \\
(10 \%)\end{array}$ & - & $\sim 23.8$ \\
\hline${ }^{154} \mathrm{Eu}$ & $\begin{array}{l}30.1 \\
(2 \%)\end{array}$ & $\begin{array}{l}0.73 \\
(6 \%)\end{array}$ & - & $\sim 30.8$ \\
\hline${ }^{155} \mathrm{Eu}$ & $\begin{array}{l}53.9 \\
(6 \%)\end{array}$ & $\begin{array}{l}2.06 \\
(5 \%)\end{array}$ & - & $\sim 56.0$ \\
\hline
\end{tabular}


and more extensive experiment was subsequently designed using a 188-L sample of U20n water (collected at 56,330 gal). Figure 3-1 shows the experimental arrangement; the water was passed through a complete series of bag filters before passing over the ultrafiltration unit, and an electric drum stirrer was used to mix the water in the barrel in order to keep the particulates suspended. Ultrafiltration was continued until the retentate fraction was reduced to approximately $3 \mathrm{~L}$; this was transferred, the barrel was spray-rinsed with about $4 \mathrm{~L}$ of deionized water, and the rinse fraction was also ultrafiltered and combined with the sample. At the end of the process, the ultrafilter was back-flushed into the retentate fraction, and the filtrate and retentate fractions were dried and gamma counted, as were all filters. Table 3-4 presents the activities measured for each fraction, normalized to $\mathrm{dpm} / \mathrm{L}$. The assembly was thoroughly cleaned, fresh filters were installed, and the entire process was repeated with a "blank" of $200 \mathrm{~L}$ of laboratory deionized water. Samples of filtrate and retentate from both the U20n sample and the deionized water were submitted for ICP analysis. In addition to the filters used in the blank experiment with deionized water, a set of unused filters was also counted.

Table 3-5 presents the results of the ICP anal$y$ sis of both the original solutions and the
Table 3-3. U20n 200-L sample calculated to day 253.5 (1983). Units are $\mathrm{dpm} / \mathrm{L}( \pm 1 \mathrm{std}$ dev \%).

\begin{tabular}{|c|c|c|c|}
\hline Nuclide & $\begin{array}{c}\text { Filters }+ \\
\text { prefilter } \\
(0.45 \mu \mathrm{m})\end{array}$ & Filtrate & Total \\
\hline${ }^{22} \mathrm{Na}$ & $\begin{array}{l}0.23 \\
(38 \%)\end{array}$ & $\begin{array}{l}2.67 \\
(9 \%)\end{array}$ & 2.90 \\
\hline${ }^{40} \mathbf{K}$ & $\begin{array}{l}3.1 \\
(12 \%)\end{array}$ & $\begin{array}{l}8.45 \\
(7 \%)\end{array}$ & 11.6 \\
\hline${ }^{54} \mathrm{Mn}$ & $\begin{array}{l}0.2 \\
(32 \%)\end{array}$ & $\begin{array}{l}0.38 \\
(33 \%)\end{array}$ & 0.58 \\
\hline${ }^{60} \mathrm{Co}$ & $\begin{array}{l}1.7 \\
(5 \%)\end{array}$ & $\begin{array}{l}3.32 \\
(2 \%)\end{array}$ & 5.0 \\
\hline${ }^{106} \mathrm{Ru}$ & $\begin{array}{l}35.2 \\
(5 \%)\end{array}$ & $\begin{array}{l}156.9 \\
(2 \%)\end{array}$ & 192 \\
\hline${ }^{125} \mathrm{Sb}$ & $\begin{array}{l}37.5 \\
(4 \%)\end{array}$ & $\begin{array}{l}2067 \\
(1 \%)\end{array}$ & 2105 \\
\hline${ }^{134} \mathrm{Cs}$ & $\begin{array}{l}0.9 \\
(4 \%)\end{array}$ & $\begin{array}{l}3.83 \\
(6 \%)\end{array}$ & 4.7 \\
\hline${ }^{137} \mathrm{Cs}$ & $\begin{array}{l}1341 \\
(1 \%)\end{array}$ & $\begin{array}{l}5135 \\
(1 \%)\end{array}$ & 6476 \\
\hline${ }^{144} \mathrm{Ce}$ & $\begin{array}{l}6.8 \\
(11 \%)\end{array}$ & $\begin{array}{l}25.8 \\
(7 \%)\end{array}$ & 32.6 \\
\hline${ }^{152} \mathrm{Eu}$ & $\begin{array}{l}3.5 \\
(3 \%)\end{array}$ & $\begin{array}{l}14.5 \\
(3 \%)\end{array}$ & 17.8 \\
\hline${ }^{154} \mathrm{Eu}$ & $\begin{array}{l}4.8 \\
(3 \%)\end{array}$ & $\begin{array}{l}18.9 \\
(3 \%)\end{array}$ & 23.7 \\
\hline${ }^{155} \mathrm{Eu}$ & $\begin{array}{l}8.5 \\
(3 \%)\end{array}$ & $\begin{array}{l}36.2 \\
(3 \%)\end{array}$ & 44.7 \\
\hline
\end{tabular}

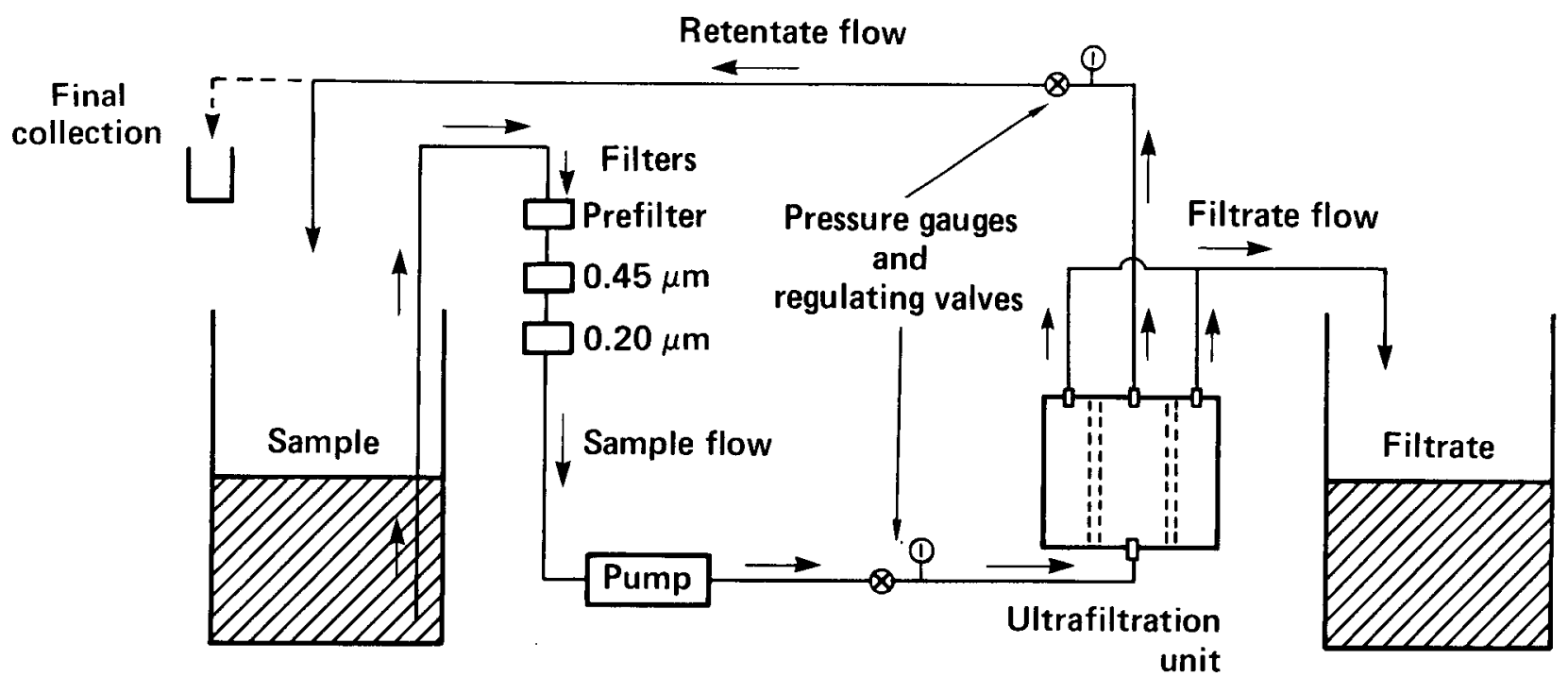

Figure 3-1. Schematic of ultrafiltration assembly. 
Table 3-4. U20n 188-L ultrafiltered samples calculated to day 253.5 (1983). Units are dpm/L ( \pm 1 std dev \%).

\begin{tabular}{|c|c|c|c|c|c|c|c|}
\hline Nuclide & $\begin{array}{l}\text { Prefilter } \\
\text { filter bag }\end{array}$ & $\begin{array}{c}0.45-\mu \mathrm{m} \\
\text { filter bag }\end{array}$ & $\begin{array}{c}0.20-\mu \mathrm{m} \\
\text { filter bag }\end{array}$ & $\begin{array}{l}0.006-\mu \mathrm{m} \\
\text { membrane }\end{array}$ & Retentate & Filtrate & Total \\
\hline${ }^{22} \mathrm{Na}$ & $N^{a}$ & NL & NL & NL & $<0.10$ & $\begin{array}{l}2.11 \\
(3.8 \%)\end{array}$ & $\sim 2.1$ \\
\hline${ }^{40} \mathrm{~K}$ & $<0.10$ & $<0.09$ & $<0.09$ & $<0.06$ & $\begin{array}{l}3.71 \\
(19.4 \%)\end{array}$ & $\begin{array}{l}2.22 \\
(18.9 \%)\end{array}$ & $\sim 5.9$ \\
\hline${ }^{54} \mathrm{Mn}$ & $\begin{array}{l}0.28 \\
(8.5 \%)\end{array}$ & $\begin{array}{l}0.04 \\
(27 \%)\end{array}$ & $\begin{array}{l}0.03 \\
(31 \%)\end{array}$ & $<0.01$ & $\begin{array}{l}0.21 \\
(57 \%)\end{array}$ & $<0.03$ & $\sim 0.56$ \\
\hline${ }^{60} \mathrm{Co}$ & $\begin{array}{l}2.61 \\
(0.9 \%)\end{array}$ & $\begin{array}{l}0.37 \\
(2.0 \%)\end{array}$ & $\begin{array}{l}0.32 \\
(1.9 \%)\end{array}$ & $\begin{array}{l}0.04 \\
(11 \%)\end{array}$ & $\begin{array}{l}1.23 \\
(3 \%)\end{array}$ & $<0.01$ & 4.57 \\
\hline${ }^{106} \mathrm{Ru}$ & $\begin{array}{l}30.77 \\
(2.0 \%)\end{array}$ & $\begin{array}{l}13.64 \\
(2.5 \%)\end{array}$ & $\begin{array}{l}10.81 \\
(2.8 \%)\end{array}$ & $\begin{array}{l}1.41 \\
(19 \%)\end{array}$ & $\begin{array}{l}93.99 \\
(3.2 \%)\end{array}$ & $\begin{array}{l}13.40 \\
(26.4 \%)\end{array}$ & 164.0 \\
\hline${ }^{125} \mathrm{Sb}$ & $\begin{array}{l}12.91 \\
(2.2 \%)\end{array}$ & $\begin{array}{l}5.25 \\
(1.3 \%)\end{array}$ & $\begin{array}{l}3.78 \\
(1.3 \%)\end{array}$ & $\begin{array}{l}0.64 \\
(4 \%)\end{array}$ & $\begin{array}{l}68.62 \\
(2.6 \%)\end{array}$ & $\begin{array}{l}1671.3 \\
(1.1 \%)\end{array}$ & 1763 \\
\hline${ }^{134} \mathrm{Cs}$ & $\begin{array}{l}0.21 \\
(20.5 \%)\end{array}$ & $\begin{array}{l}0.08 \\
(9.0 \%)\end{array}$ & $\begin{array}{l}0.06 \\
(15 \%)\end{array}$ & NL & $\begin{array}{l}1.23 \\
(9.3 \%)\end{array}$ & $\begin{array}{l}2.24 \\
(3.6 \%)\end{array}$ & -3.8 \\
\hline${ }^{137} \mathrm{Cs}$ & $\begin{array}{l}500.9 \\
(0.8 \%)\end{array}$ & $\begin{array}{l}141.2 \\
(1.0 \%)\end{array}$ & $\begin{array}{l}95.21 \\
(0.8 \%)\end{array}$ & $\begin{array}{l}31.11 \\
(0.8 \%)\end{array}$ & $\begin{array}{l}1931 \\
(1.1 \%)\end{array}$ & $\begin{array}{l}3276 \\
(0.8 \%)\end{array}$ & 5975 \\
\hline${ }^{144} \mathrm{Ce}$ & $\begin{array}{l}7.34 \\
(6.4 \%)\end{array}$ & $\begin{array}{l}1.93 \\
(9.6 \%)\end{array}$ & $\begin{array}{l}1.43 \\
(11 \%)\end{array}$ & $\begin{array}{l}0.38 \\
(20 \%)\end{array}$ & $\begin{array}{l}15.42 \\
(9.2 \%)\end{array}$ & NL & $\sim 26.5$ \\
\hline${ }^{152} \mathrm{Eu}$ & $\begin{array}{l}4.01 \\
(1.7 \%)\end{array}$ & $\begin{array}{l}1.01 \\
(2.6 \%)\end{array}$ & $\begin{array}{l}0.75 \\
(2.0 \%)\end{array}$ & $\begin{array}{l}0.14 \\
(19 \%)\end{array}$ & $\begin{array}{l}8.51 \\
(2.8 \%)\end{array}$ & $<0.07$ & $\sim 14.4$ \\
\hline${ }^{154} \mathrm{Eu}$ & $\begin{array}{l}5.61 \\
(1.2 \%)\end{array}$ & $\begin{array}{l}1.42 \\
(1.7 \%)\end{array}$ & $\begin{array}{l}1.05 \\
(1.4 \%)\end{array}$ & $\begin{array}{l}0.19 \\
(10.8 \%)\end{array}$ & $\begin{array}{l}11.54 \\
(2.0 \%)\end{array}$ & $<0.16$ & $\sim 20.4$ \\
\hline${ }^{155} \mathrm{Eu}$ & $\begin{array}{l}9.34 \\
(1.7 \%)\end{array}$ & $\begin{array}{l}2.45 \\
(3.2 \%)\end{array}$ & $\begin{array}{l}1.77 \\
(2.9 \%)\end{array}$ & $\begin{array}{l}0.43 \\
(3.1 \%)\end{array}$ & $\begin{array}{l}16.38 \\
(5.4 \%)\end{array}$ & $<0.34$ & $\sim 30.4$ \\
\hline
\end{tabular}

a No limit calculated.

Notes: There is an interfering gamma ray for ${ }^{22} \mathrm{Na}$ and ${ }^{154} \mathrm{Eu}$ at $1274 \mathrm{keV}$. Calculated zero time for measured activities is day 253.5 (1983). Zero time calculated for limits is count time.

Table 3-5. Ultrafiltration-study retentate analysis $(\mu \mathrm{g} / \mathrm{mL})$.

\begin{tabular}{lllcc}
\hline Element & U20n 9/83 & $\begin{array}{c}\text { U20n retentate } \\
\text { concentration 1:70 }\end{array}$ & $\begin{array}{c}\text { DI } \\
\text { water }\end{array}$ & $\begin{array}{c}\text { DI retentate } \\
\text { concentration 1:70 }\end{array}$ \\
\hline Aluminum & 2.13 & 24.8 & $<0.020$ & $<0.020$ \\
Boron & 0.106 & 1.58 & $<0.004$ & $<0.004$ \\
Copper & $<0.003$ & 0.006 & - & 0.161 \\
Iron & 0.294 & 3.26 & 0.005 & 0.023 \\
Lithium & 0.161 & 0.286 & 0.001 & 0.012 \\
Manganese & 0.108 & 0.449 & $<0.0005$ & 0.003 \\
Molybdenum & 0.021 & 0.109 & - & 0.010 \\
Nickel & $<0.008$ & 0.008 & -0.008 & 0.080 \\
Phosphorus & $<0.124$ & 0.141 & - & 0.060 \\
Lead & 0.026 & 0.142 & 0.090 & 0.041 \\
Silicon & 33 & 122 & $<0.012$ & 0.028 \\
Strontium & 0.004 & 0.068 & - & 0.002 \\
Titanium & - & 0.103 & - & 0.078 \\
Uranium & $<0.084$ & - & $<.275$ \\
Zinc & $<0.008$ & 0.065 & $<0.002$ & 0.001 \\
Zirconium & - & 0.018 & $<0.536$ & 0.478 \\
Calcium & 1.58 & 8.28 & 0.024 & 0.504 \\
Potassium & 3.11 & 24.7 & 0.041 & 0.173 \\
Magnesium & 0.165 & 0.456 & & 0.208 \\
Sodium & 73.05 & 176 & & \\
\hline
\end{tabular}


deionized water blank and the retentate fractions after these samples were ultrafiltered. The filtrate:retentate volume ratio in both cases was approximately 70 . Most elements show some concentration in the retentate, with factors ranging from less than 2 to 17. As reported in Section 2, the total salt concentration in the retentate was approximately 15 times the ultrafiltrate salt concentration. This suggests that approximately $18 \%$ of the total salt content $<0.45-\mu \mathrm{m}$ was present as colloidal particles in the $0.006-$ to $0.45-\mu \mathrm{m}$ size range.

Table 3-6 presents the results of all blank determinations, both on unused filters and on filters and retentate from the deionized water experiment (for the prefilter bag, results are presented from a specimen used in processing a low-activity Nash satellite sample, which has essentially zero activity compared with the Cheshire water). The only significant activity noted (discounting the ${ }^{155} \mathrm{Eu}$ value for the $0.45-\mu \mathrm{m}$ blank bag, see Section 3.1 ) is ${ }^{137} \mathrm{Cs}$ in the deionized (DI) water experiment. As may be seen from Tables 3-2 through 3-4, ${ }^{137} \mathrm{Cs}$ shows by far the highest activity found in both the particulate and dissolved fractions of the Cheshire sample; we believe that these "blank" values represent the level of cross-contamination to be expected from reuse of the same filtration system, even with decontamination efforts between uses. Table 3-6 shows total dpm per sample; when the values of Table 3-4 are converted to total $\mathrm{dpm}$, it can be seen that the ${ }^{137} \mathrm{Cs}$ carryover is $\leq 0.01 \%$. Table $3-4$ also shows that small but measurable levels of activity $(\sim 1 \%)$ were retained on the ultrafilter even after back-flushing.

As discussed in Section 2.2, the $0.45-\mu \mathrm{m}$ filtrate activities, the ultrafiltrate activities, and the total sample activity inventories are all in reasonable agreement, particularly when realistic experimental uncertainties are considered in place of the tabulated values based on counting statistics only. From the standpoint of the filtration experiment, there are some differences in activity distribution that may be significant (see Table 3-7). The composite sample retentate showed appreciably lower activity levels than the 188 - $\mathrm{L}$ sample retentate, the $>0.45-\mu \mathrm{m}$ fraction of the composite sample was considerably more active than the same fraction for the large-volume samples, and the 188-L sample showed less ${ }^{137} \mathrm{Cs}$ and ${ }^{125} \mathrm{Sb}$ in the $>0.45-\mu \mathrm{m}$ fraction than did the $200-\mathrm{L}$ sample.

These differences may be related to the fact that the filters had different amounts of water passed through them $-28 \mathrm{~L}$ in the case of the

Table 3-6. Ultrafiltration-study blanks (total dpm). Calculated zero time is count time (AugustOctober 1984).

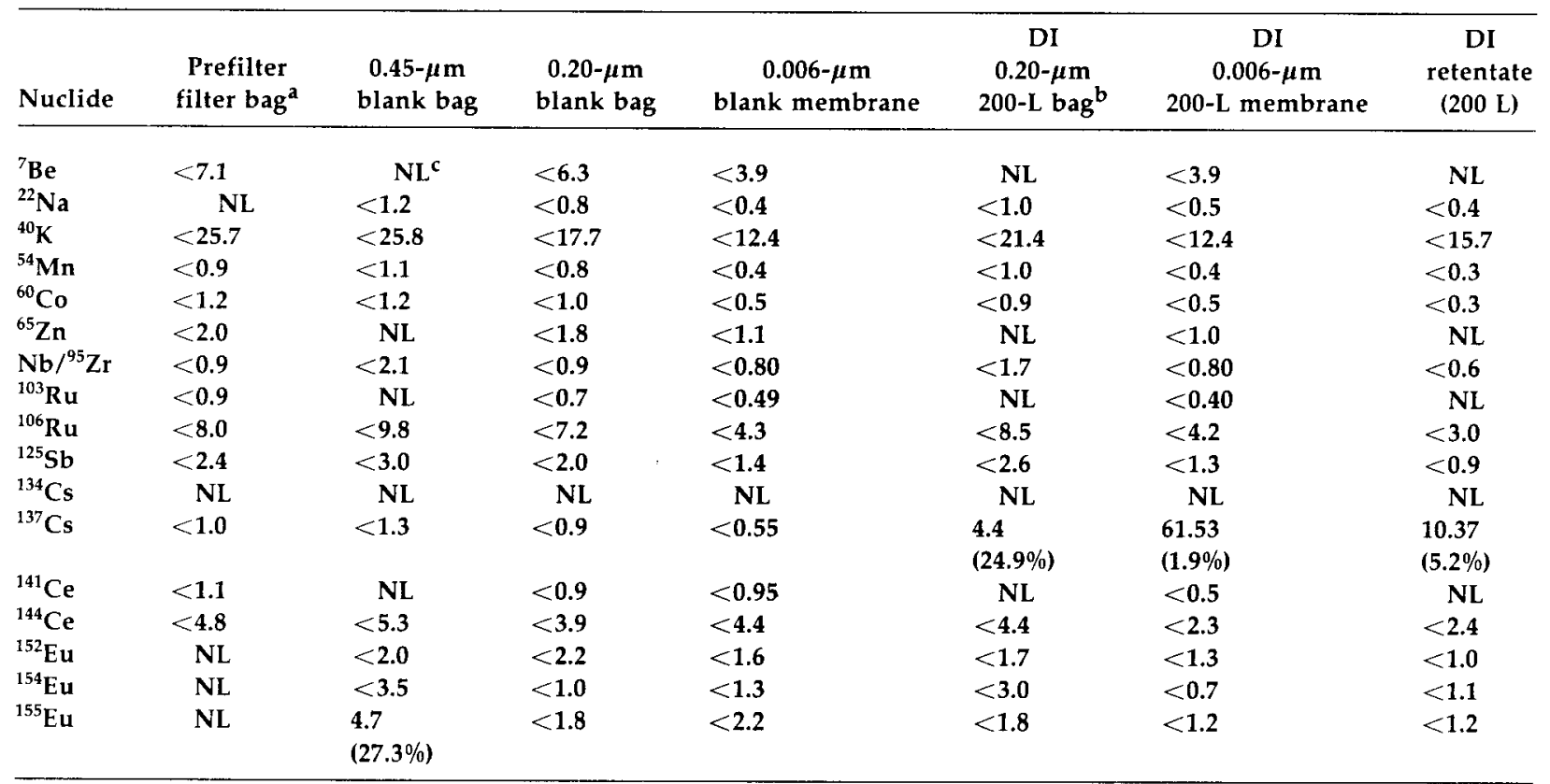

a Prefilter is from $8 / 83$ Nash sample at $200 \mathrm{~L}$.

${ }^{b}$ Followup filtration set after U20n - 200 L of DI water.

c No limit calculated. 
Table 3-7. Comparison of filter sets for the U20n ultrafiltration study. Units are total dpm ( \pm 1 std dev \%). The limits are calculated at count time. No half-life corrections are calculated.

\begin{tabular}{|c|c|c|c|c|}
\hline Nuclide & $\begin{array}{c}0.45-\mu \mathrm{m} \\
11 / 83(\text { adj. })^{\mathrm{a}}\end{array}$ & $\begin{array}{c}0.45-\mu \mathrm{m} \\
8 / 84\end{array}$ & $\begin{array}{c}0.006 \text { retentate } \\
11 / 83 \text { (adj.) }\end{array}$ & $\begin{array}{c}0.006 \text { retentate } \\
8 / 84\end{array}$ \\
\hline$\overline{{ }^{7} \mathrm{Be}}$ & $<273$ & $<3.5$ & $<10.6$ & $\mathbf{N L}^{\mathbf{b}}$ \\
\hline${ }^{22} \mathrm{Na}$ & $\begin{array}{l}27.9 \\
(7.8 \%)\end{array}$ & NL & $\begin{array}{l}48 \\
(7.8 \%)\end{array}$ & $<18.7$ \\
\hline${ }^{40} \mathrm{~K}$ & $\begin{array}{l}627.5 \\
(11.6 \%)\end{array}$ & $<17.1$ & $\begin{array}{l}168.6 \\
(33 \%)\end{array}$ & $\begin{array}{l}697.7 \\
(19.4 \%)\end{array}$ \\
\hline${ }^{54} \mathrm{Mn}$ & $\begin{array}{l}28.8 \\
(21.1 \%)\end{array}$ & $\begin{array}{l}7.3 \\
(27 \%)\end{array}$ & $<2.7$ & $\begin{array}{l}39.1 \\
(57 \%)\end{array}$ \\
\hline${ }^{65} \mathrm{Zn}$ & $<6.8$ & $<1.6$ & $<5.7$ & NL \\
\hline${ }^{60} \mathrm{Co}$ & $\begin{array}{l}248.9 \\
(2.1 \%)\end{array}$ & $\begin{array}{l}70.3 \\
(2.0 \%)\end{array}$ & $\begin{array}{l}9.8 \\
(26.8 \%)\end{array}$ & $\begin{array}{l}230.8 \\
(3 \%)\end{array}$ \\
\hline $\mathrm{Nb} / \mathrm{Zr}$ & $<3.4$ & $<0.9$ & $<3.9$ & $<14$ \\
\hline${ }^{103} \mathrm{Ru}$ & $<25$ & $<3.3$ & $<7.0$ & NL \\
\hline $\begin{array}{l}{ }^{106} \mathrm{Ru} \\
\quad(622 \mathrm{keV})\end{array}$ & $\begin{array}{l}5980 \\
(2.6 \%)\end{array}$ & $\begin{array}{l}2564 \\
(2.5 \%)\end{array}$ & $\begin{array}{l}724 \\
(8.5 \%)\end{array}$ & $\begin{array}{l}1.767 \times 10^{4} \\
(3.2 \%)\end{array}$ \\
\hline${ }^{125} \mathrm{Sb}$ & $\begin{array}{l}2423 \\
(3.0 \%)\end{array}$ & $\begin{array}{l}987.9 \\
(1.3 \%)\end{array}$ & $\begin{array}{l}3430 \\
(1.7 \%)\end{array}$ & $\begin{array}{l}1.29 \times 10^{4} \\
(2.6 \%)\end{array}$ \\
\hline${ }^{134} \mathrm{Cs}$ & $\begin{array}{l}162.9 \\
(3.9 \%)\end{array}$ & $\begin{array}{l}14.4 \\
(9.0 \%)\end{array}$ & $\begin{array}{l}14 \\
(30.5 \%)\end{array}$ & $\begin{array}{l}230.9 \\
(9.3 \%)\end{array}$ \\
\hline${ }^{137} \mathrm{Cs}$ & $\begin{array}{l}2.52 \times 10^{5} \\
(0.9 \%)\end{array}$ & $\begin{array}{l}2.654 \times 10^{4} \\
(1.0 \%)\end{array}$ & $\begin{array}{l}1.92 \times 10^{4} \\
(4.6 \%)\end{array}$ & $\begin{array}{l}3.63 \times 10^{5} \\
(1.1 \%)\end{array}$ \\
\hline${ }^{141} \mathrm{Ce}$ & $<24.4$ & $<3.4$ & $<6.5$ & NL \\
\hline${ }^{144} \mathrm{Ce}$ & $\begin{array}{l}1.16 \times 10^{3} \\
(10.6 \%)\end{array}$ & $\begin{array}{l}363.2 \\
(9.6 \%)\end{array}$ & $\begin{array}{l}254 \\
(15 \%)\end{array}$ & $\begin{array}{l}2.90 \times 10^{3} \\
(9.2 \%)\end{array}$ \\
\hline${ }^{152} \mathrm{Eu}$ & $\begin{array}{l}614.6 \\
(2.5 \%)\end{array}$ & $\begin{array}{l}189.9 \\
(2.6 \%)\end{array}$ & $\begin{array}{l}117.5 \\
(9.2 \%)\end{array}$ & $\begin{array}{l}1.60 \times 10^{3} \\
(2.8 \%)\end{array}$ \\
\hline${ }^{154} \mathbf{E u}^{\mathrm{c}}$ & $\begin{array}{l}858.2 \\
(2.2 \%)\end{array}$ & $\begin{array}{l}267 \\
(1.7 \%)\end{array}$ & $\begin{array}{l}145 \\
(6.1 \%)\end{array}$ & $\begin{array}{l}2.17 \times 10^{3} \\
(2.0 \%)\end{array}$ \\
\hline${ }^{155} \mathrm{Eu}$ & $\begin{array}{l}1445 \\
(2.9 \%)\end{array}$ & $\begin{array}{l}460.2 \\
(3.2 \%)\end{array}$ & $\begin{array}{l}412 \\
(4.5 \%)\end{array}$ & $\begin{array}{l}3.08 \times 10^{3} \\
(5.4 \%)\end{array}$ \\
\hline
\end{tabular}

a $11 / 83$ activities have been multiplied by $188 / 28$ to compare with $8 / 84$ activities on an equal volume basis.

b No limit calculated.

${ }^{\text {c }}{ }^{154} \mathrm{Eu}$ has an interfering gamma ray for the calculation of ${ }^{22} \mathrm{Na}$.

composite sample, $200 \mathrm{~L}$ for the "standard treatment" large-volume sample, and several times that amount (because the ultrafiltration recycling was passed through the entire filter string) for the 188 - L sample. This may have resulted in disaggregation of the larger particles initially trapped on the filters, with some of the activity transferred to the smaller size fractions. This must remain speculative, because there were other differences that could have affected the results-the samples were stored for different lengths of time between collection and processing, and the prefilter and filter combinations used were not identical for any of the samples. A second experiment is planned using multiple filters at each stage and single-pass filtration prior to the ultrafiltration process in order to resolve some of these questions.
The most significant result, however, is that essentially none of the manganese, cobalt, cesium, nor europium, and very little of the ruthenium activity passes through the ultrafilter, even though significant amounts of these nuclides are detected in the $0.45-\mu \mathrm{m}$ filtrate. This strongly suggests that much of the transition element and lanthanide activity that is treated as dissolved on the basis of traditional methods is in fact associated with particles with dimensions $>6 \mathrm{~nm}$. If correct, this observation will have profound implications for both geochemical and transport modeling of these elements. Related to this is the observation that the retentate/filtrate activity ratios in Table 3-4 are much higher than the chemical ratios in Table 3-5. Although chemical analyses were not performed for most of the elements present as radionuclides, 
the trends in the data suggest that "dissolved" radioisotopes may not act as tracers for their "dissolved" stable counterparts.

In spite of remaining uncertainties, four conclusions can be reached:

1. Significant amounts of activity (relative to "dissolved" concentrations) may be found associated with suspended particles, and the particulate/ dissolved activity ratios are different for different nuclides.

2. There is at least some evidence for the presence of activity on particles that are too small to be filtered on conventional methods, especially in the case of transition and lanthanide elements (see Section 2.2).

3. The type and technique of filtration employed are clearly capable of producing alterations in the relative amounts of activity assigned to the various particle size ranges and the dissolved phase.

4. Further work on these issues is needed.

\subsection{References}

1. Stone, R., M. R. Ruggieri, L. L. Rogers, D. O. Emerson, and R. W. Buddemeier, 1982, Potential for Saturated Groundwater System Contamination at the Lawrence Livermore National Laboratory, Lawrence Livermore National Laboratory, Livermore, CA, UCRL-53426.

2. Thompson, J., 1984, Los Alamos National Laboratory, Los Alamos, NM, personal communication, 1984. 


\section{Cambric Plume Study}

(Contributors: M. R. Ruggieri and R. W. Buddemeier)

LLNL and DRI have initiated a collaborative study of water and radionuclide transport processes in the unique environment provided by the steady-state recharge plume beneath the ditch that carries the effluent water from the RNM-2S pumping experiment. This environment contains a complete range of conditions from natural desert floor through a continuum of moisture contents and unsaturated flow conditions to saturated or nearly saturated flow directly under the ditch. The geologic medium is tuffaceous alluvium, which is characteristic of much of NTS, and the input water has been well characterized over time in terms of its radionuclide content, chemistry, and flow rate. Because the plume is located in the shallow subsurface and may reasonably be treated as a steady-state structure, experimental access is simple and inexpensive, and reproducible and progressive experimental designs can be employed. We expect the results to provide valuable insights into unsaturated zone water transport processes and various aspects of radionuclide transport under both saturated and unsaturated conditions. Plume studies will provide information directly relevant to the potential of ditch recharge to alter the tritium signal at RNM-2S. Unsaturated transport results will provide an important information base relevant to evaluation of the potential for ground-water contamination by enhanced local recharge through craters and at other point sources of potential contamination (e.g., decontamination washdown areas). Finally, access to a shallow saturated alluvial flow regime will offer the potential for performing inexpensive and technically feasible field-scale tracer experiments that will be applicable to models of solute behavior in the deeper aquifers.

DRI is investigating the water budget and chemical and stable isotopic characteristics of the ditch and discharge pond and is modeling the recharge plume; these efforts will be reported elsewhere. This section deals primarily with soil moisture and tritium results obtained in the joint LLNL-DRI sampling effort.

In 1982, DRI submitted to LLNL for soil tritium analyses 7 core samples from a $20-\mathrm{ft}$ borehole located $3 \mathrm{ft}$ from the edge of the ditch. The water obtained by freeze-drying showed tritium activities of about $1230 \mathrm{dpm} / \mathrm{mL}$ at a depth of $2 \mathrm{ft}$, and $4200-5400 \mathrm{dpm} / \mathrm{mL}$ over the interval 4-20 ft. Three of these samples were subse- quently baked out under vacuum at $120^{\circ} \mathrm{C}$; the second (bound water) fractions recovered had tritium activities identical to the freeze-dry (loose water) fractions, indicating isotopic equilibrium across a range of soil pore sizes.

These preliminary analyses demonstrated the existence of unsaturated zone tritium activities comparable to that of contemporaneous ditch water (RNM-2S effluent). In early 1983, DRI cored samples at locations 50 and $100 \mathrm{ft}$ from the ditch in order to determine background values and the outer boundary of the plume. The results of tritium analyses on these soil samples are reported in Table 4-1.

Based on these preliminary studies, an experimental plot was designed and installed during the summer of 1983 . Figure $4-1$ shows the location of the study site relative to RNM-1, RNM-2S, and the ditch. Also indicated on the figure are the locations of three flumes installed by DRI to measure water flow, and sampling stations established in the outflow pond to study seasonal changes in recharge water characteristics (to be reported elsewhere).

Figure 4-2 shows the detailed layout of the instrument plot. The initial design called for instrumentation to a depth of $20 \mathrm{ft}$, but the soil auger used to drill the holes could not consistently penetrate a gravel layer encountered in the 12- to $15-\mathrm{ft}$ range. Instrumentation includes suction lysimeters for soil water sampling, tensiometers, resistance cells, and a neutron probe access tube to monitor soil moisture content. Drive core samples were taken for tritium analysis at selected depths during the installation process. Figure 4-3 is a vertical section across the study site showing all of the core and instrument positions in profile.

Since the time of installation, the instruments have been monitored weekly and lysimeter samples (when available) have been collected monthly by DRI field personnel.

Table 4-1. Cambric area soil ${ }^{3} \mathrm{H}$ activity.

\begin{tabular}{cccc}
\hline \multirow{2}{*}{$\begin{array}{c}\text { Distance from } \\
\text { ditch (ft) }\end{array}$} & $\begin{array}{c}\text { Sample } \\
\text { depth }(\mathrm{ft})\end{array}$ & $\mathrm{dpm} / \mathrm{mL}$ & $\mathrm{pCi} / \mathrm{mL}$ \\
\cline { 3 - 4 } 50 & $0-2$ & $125.2 \pm 24.4$ & $56.4 \pm 11$ \\
50 & $2-4$ & $5.3 \pm 2.2$ & $2.4 \pm 1$ \\
50 & $8-10$ & $0.4 \pm 0.4$ & $0.2 \pm 0.2$ \\
50 & $18-20$ & $0.1 \pm 0.1$ & $0.06 \pm 0.6$ \\
100 & $0-2$ & $11.0 \pm 2.2$ & $4.94 \pm 1$ \\
100 & $8-10$ & $<0.1$ & $<0.06$ \\
100 & $18-20$ & $<0.1$ & $<0.06$ \\
\hline
\end{tabular}




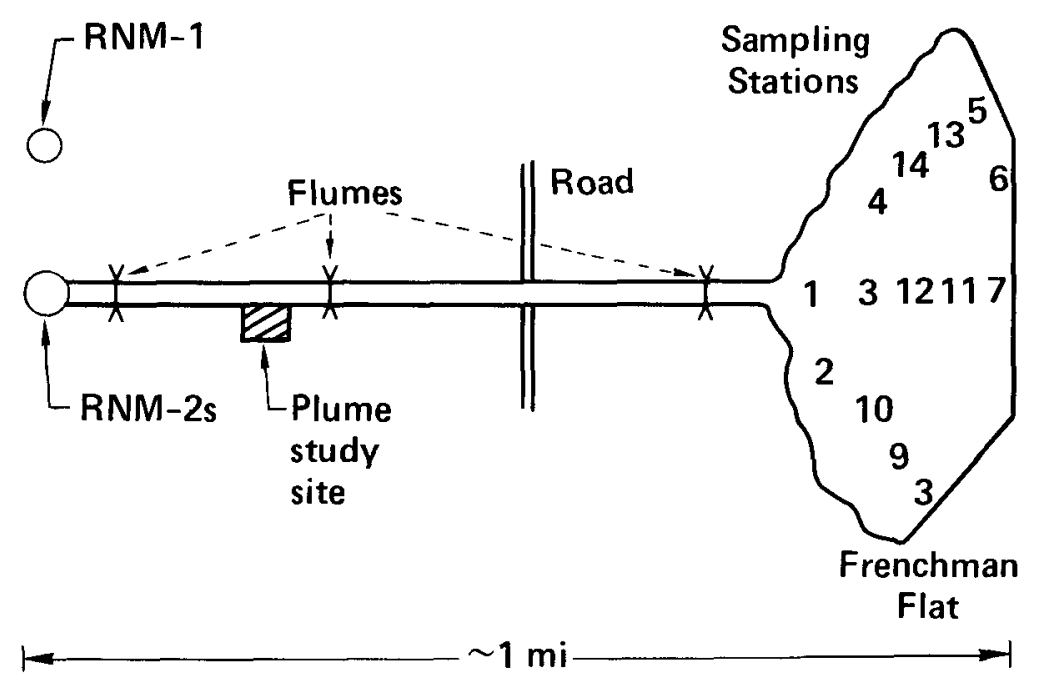

Figure 4-1. Cambric site ditch and pond.

Outer (west) edge of ditch berm

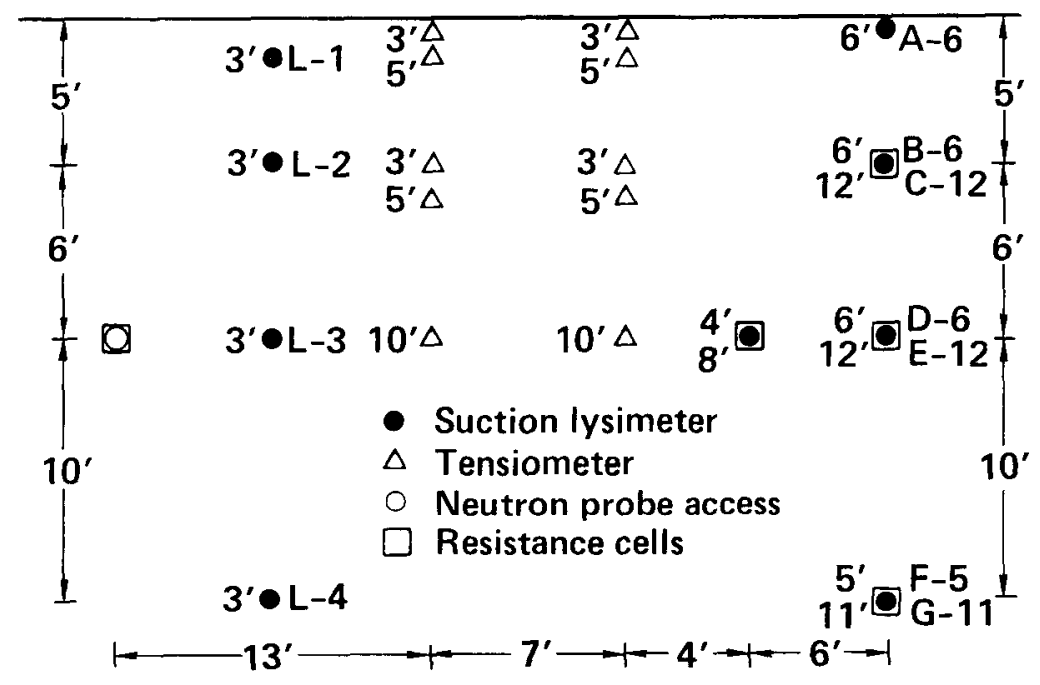

Figure 4-2. Cambric unsaturated zone study site.

\subsection{Results}

Based on measured flow rates and estimates of maximum evapotranspiration rates, DRI personnel have estimated that infiltration losses through the bottom of the ditch amount to 175 $\mathrm{gal} / \mathrm{min}$ between the first and third flumes. Assuming a 1-km flume separation, $2-\mathrm{m}$ ditch width, and a soil porosity of $25 \%$, this yields a piston flow pore velocity of $20 \mathrm{~cm} / \mathrm{d}$ or $73 \mathrm{~m} / \mathrm{y}$. Since the pumping experiment has been running for more than $9 \mathrm{y}$ and the water table is at a depth of about $220 \mathrm{~m}$, it seems likely that even with allowances for dispersion the recharge plume has reached the water table. ${ }^{1}$

Although a few of the FY84 samples remain to be analyzed, the tritium results from a majority of the samples collected are reported in Table 4-2 and Fig. 4-4. Counting uncertainties are generally less than $1 \%$. For better comparison with the ditch 


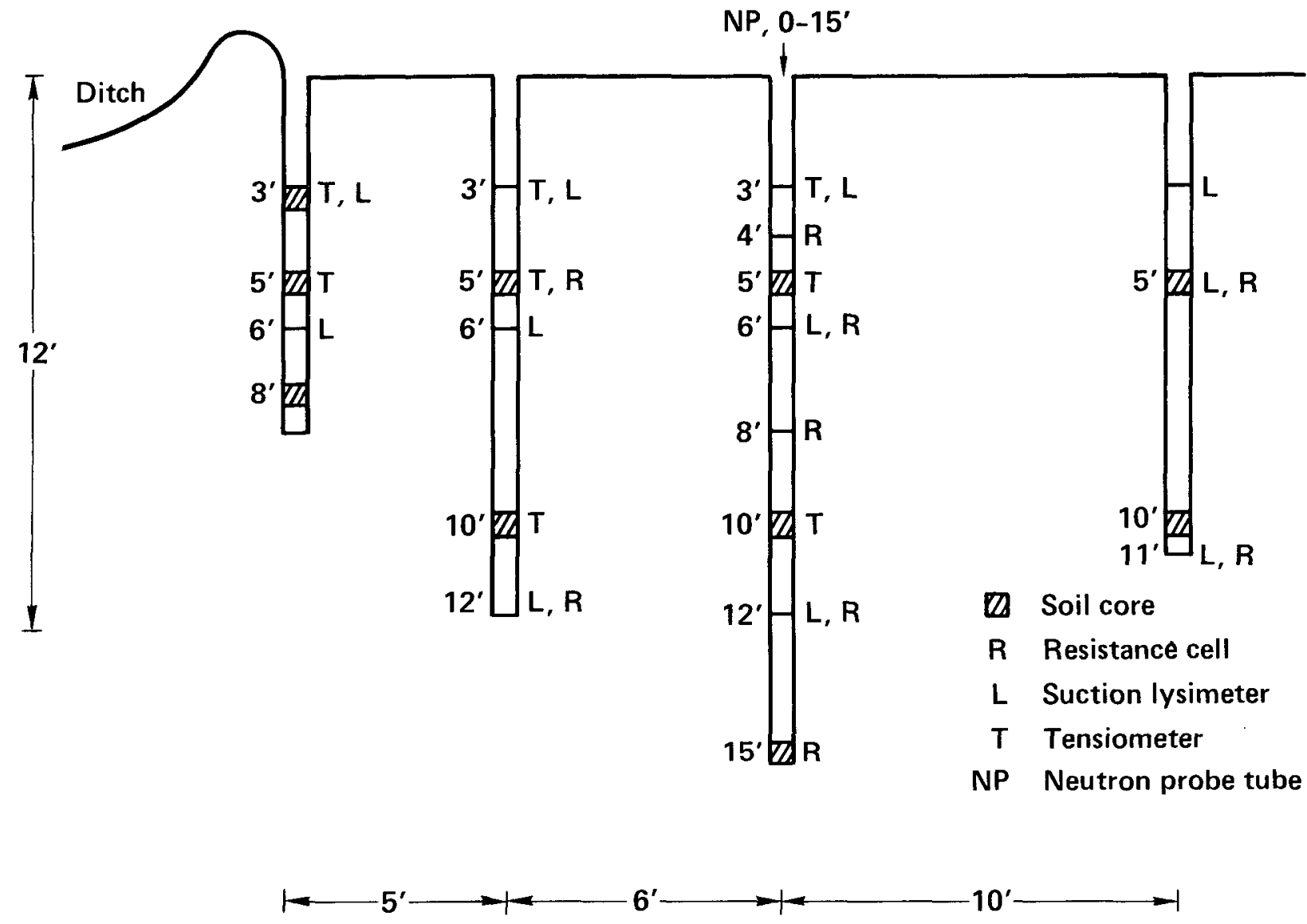

Figure 4-3. Vertical view of soil instruments and samples at the Cambric study site.

water activity, data reported by $\mathrm{LANL}^{2-4}$ are reported along with the more sporadic LLNL analyses. There appears to be a consistent $5-10 \%$ difference between LLNL and LANL ${ }^{3} \mathrm{H}$ analyses of the ditch water, the cause of which is under investigation. In the discussion that follows, the lysimeter data are compared with the LLNL ditch values for internal consistency. The 3 - $\mathrm{ft}$ lysimeters generally failed to yield samples because of dry soil conditions; some of the other lysimeters failed (loss of vacuum) even though soil moisture should have been adequate to obtain samples. The soil core and initial lysimeter sample activities are portrayed schematically in Fig. 4-5. The soil moisture data are presented in Appendix B. A detailed interpretation of these results has not yet been completed; it will be reported later. A qualitative summary of the major features of the results is shown by the moisture zones indicated in Fig. 4-5. Although none of the instruments indicates fully saturated conditions, very wet soils are observed next to the ditch and extending out at least $5 \mathrm{ft}$ at a depth of 12-15 ft. Elevated moisture levels are found at the 11-ft installation, but at $21 \mathrm{ft}$ the soils are dry (presumably the normal desert condition). Seasonal variations and transient rainfall responses are observed in the shallower and drier locations, but these have little or no effect on the near-ditch plume.

The basic pattern of tritium activities is quite consistent. Table 4-2 shows that lysimeter A-6 is very close to equilibrium with the ditch water, with time lags of no more than a few weeks. Lysimeter C-12 appears to lag the ditch water in activity by about $1.5 \mathrm{y}$. Lysimeter D-6 has recently shown a significant increase in activity; if this represents the transmission of the the tritium breakthrough to this sampling point, a transit time of about $7 \mathrm{y}$ is implied. E-12, which did not function for nearly a year, has recently started yielding samples that appear to be in equilibrium with D-6. This would indicate primarily horizontal rather than vertical migration of the water in this zone.

The results demonstrate the feasibility of using soil sampling techniques to intercept and identify various phases of the RNM-2S tritium 


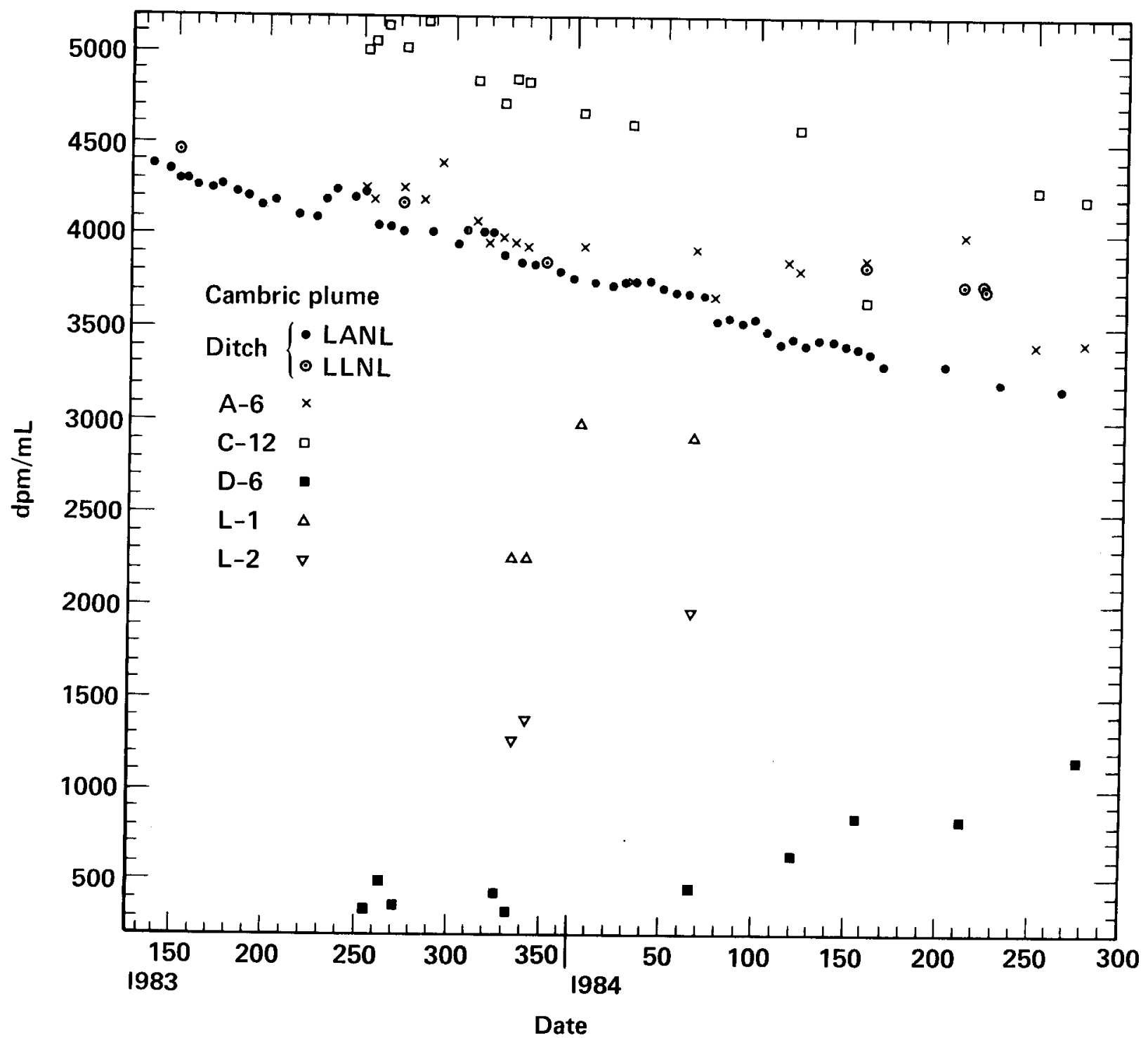

Figure 4-4. Chronological record of ditch and lysimeter ${ }^{3} \mathbf{H}$ values. 
Table 4-2. Cambric ditch and lysimeter ${ }^{3} \mathrm{H}(\mathrm{dpm} / \mathrm{mL}){ }^{\mathrm{a}}$

\begin{tabular}{|c|c|c|c|c|c|c|c|}
\hline Date & Ditch & L-1 & L-2 & A-6 & $C-12$ & D-6 & E-12 \\
\hline 83131 & $4375^{b}$ & & & & & & \\
\hline 145 & $4356^{b}$ & & & & & & \\
\hline 154 & $4294^{b}$ & & & & & & \\
\hline 154 & 4455 & & & & & & \\
\hline 160 & $4296^{b}$ & & & & & & \\
\hline 168 & $4264^{b}$ & & & & & & \\
\hline 173 & $4268^{b}$ & & & & & & \\
\hline 181 & $4238^{b}$ & & & & & & \\
\hline 188 & $4215^{b}$ & & & & & & \\
\hline 195 & $4161^{b}$ & & & & & & \\
\hline 202 & $4183^{b}$ & & & & & & \\
\hline 215 & $4113^{b}$ & & & & & & \\
\hline 223 & $4093^{b}$ & & & & & & \\
\hline 229 & $4196^{b}$ & & & & & & \\
\hline 237 & $4249^{b}$ & & & & & & \\
\hline 245 & $4210^{b}$ & & & & & & \\
\hline 250 & & & & 4258 & 5010 & & \\
\hline 251 & $4232^{b}$ & & & & & & \\
\hline 255 & & & & 4205 & 5047 & 354 & \\
\hline 258 & $4064^{b}$ & & & & & & \\
\hline 262 & & & & & 5151 & 495 & \\
\hline 265 & $4051^{b}$ & & & & & & \\
\hline 271 & $4020^{b}$ & & & & & & \\
\hline 271 & 4186 & & & 4268 & & 374 & \\
\hline 272 & & & & 4206 & 5029 & & \\
\hline 283 & & & & & 5181 & & \\
\hline 287 & $4026^{C}$ & & & & & & \\
\hline 292 & & & & 4395 & & & \\
\hline 83300 & $3965^{C}$ & & & & & & \\
\hline 306 & $4028^{c}$ & & & & & & \\
\hline 311 & & & & 4090 & 4842 & & \\
\hline 314 & $4021^{c}$ & & & & & & \\
\hline 318 & & & & 3971 & & & \\
\hline 320 & $4019^{\mathfrak{C}}$ & & & & & & \\
\hline 325 & & & & 4002 & 4739 & 443 & \\
\hline 326 & $3895^{\mathrm{C}}$ & & & & & & \\
\hline 332 & & 2270 & 1294 & 3967 & 4858 & 338 & \\
\hline 335 & $3857^{c}$ & & & & & & \\
\hline 339 & & 2267 & 1391 & 3955 & 4849 & & \\
\hline 343 & $3854^{c}$ & & . & & & & \\
\hline 348 & 3857 & & & & & & \\
\hline 356 & $3812^{\mathfrak{c}}$ & & & & & & \\
\hline 363 & $3784^{\mathrm{C}}$ & & & & & & \\
\hline 84003 & & 3000 & & 3953 & 4669 & & \\
\hline 012 & $3760^{c}$ & & & & & & \\
\hline 018 & $3742^{C}$ & & & & & & \\
\hline 026 & $3764^{c}$ & & & & & & \\
\hline 030 & & & & 3771 & 4613 & & \\
\hline 033 & $3768^{c}$ & & & & & & \\
\hline 040 & $3769^{c}$ & & & & & & \\
\hline 047 & $3732^{c}$ & & & & & & \\
\hline 054 & $3712^{\mathrm{c}}$ & & & & & & \\
\hline 061 & $3710^{\mathrm{c}}$ & & & & & & \\
\hline 065 & & 2929 & 1993 & 3694 & & 568 & \\
\hline 068 & $3685^{d}$ & & & & & & \\
\hline 076 & $3552^{d}$ & & & & & & \\
\hline 082 & $3574^{\mathrm{d}}$ & & & & & & \\
\hline 089 & $3552^{d}$ & & & & & & \\
\hline 096 & $3574^{\mathrm{d}}$ & & & & & & \\
\hline 103 & $3508^{d}$ & & & & & & \\
\hline 111 & $3441^{d}$ & & & & & & \\
\hline 84114 & & & & 3881 & & & \\
\hline 117 & $3463^{d}$ & & & & & & \\
\hline
\end{tabular}


Table 4-2. (Continued)

\begin{tabular}{|c|c|c|c|c|c|c|c|}
\hline Date & Ditch & L-1 & L-2 & A-6 & C-12 & D-6 & E-12 \\
\hline 121 & & & & 3832 & 4596 & 672 & \\
\hline 124 & $3441^{d}$ & & & & & & \\
\hline 132 & $3463^{d}$ & - & & & & & \\
\hline 139 & $3463^{d}$ & & & & & & \\
\hline 146 & $3441^{d}$ & & & & & & \\
\hline 153 & $3419^{d}$ & & & & & & \\
\hline 156 & $3863^{d}$ & & & 3898 & 3667 & 871 & \\
\hline 159 & $3397^{\mathrm{d}}$ & & & & & & \\
\hline 166 & $3330^{\mathrm{d}}$ & & & & & & \\
\hline 200 & $3330^{d}$ & & & & & & \\
\hline 212 & 3759 & & & 4032 & & 871 & 853 \\
\hline 220 & 3756 & & & & & & \\
\hline 221 & 3754 & & & & & & \\
\hline 230 & $3241^{d}$ & & & & & & \\
\hline 248 & & & & 3437 & 4282 & & \\
\hline 263 & $3197^{d}$ & & & & & & \\
\hline 275 & & & & 3443 & 4231 & 1154 & \\
\hline
\end{tabular}

a See Figs. 4-1 and 4-2 for instrument depths and locations.

b LANL data, Ref. 2.

c LANL data, Ref. 3.

d LANL data, Ref. 4.

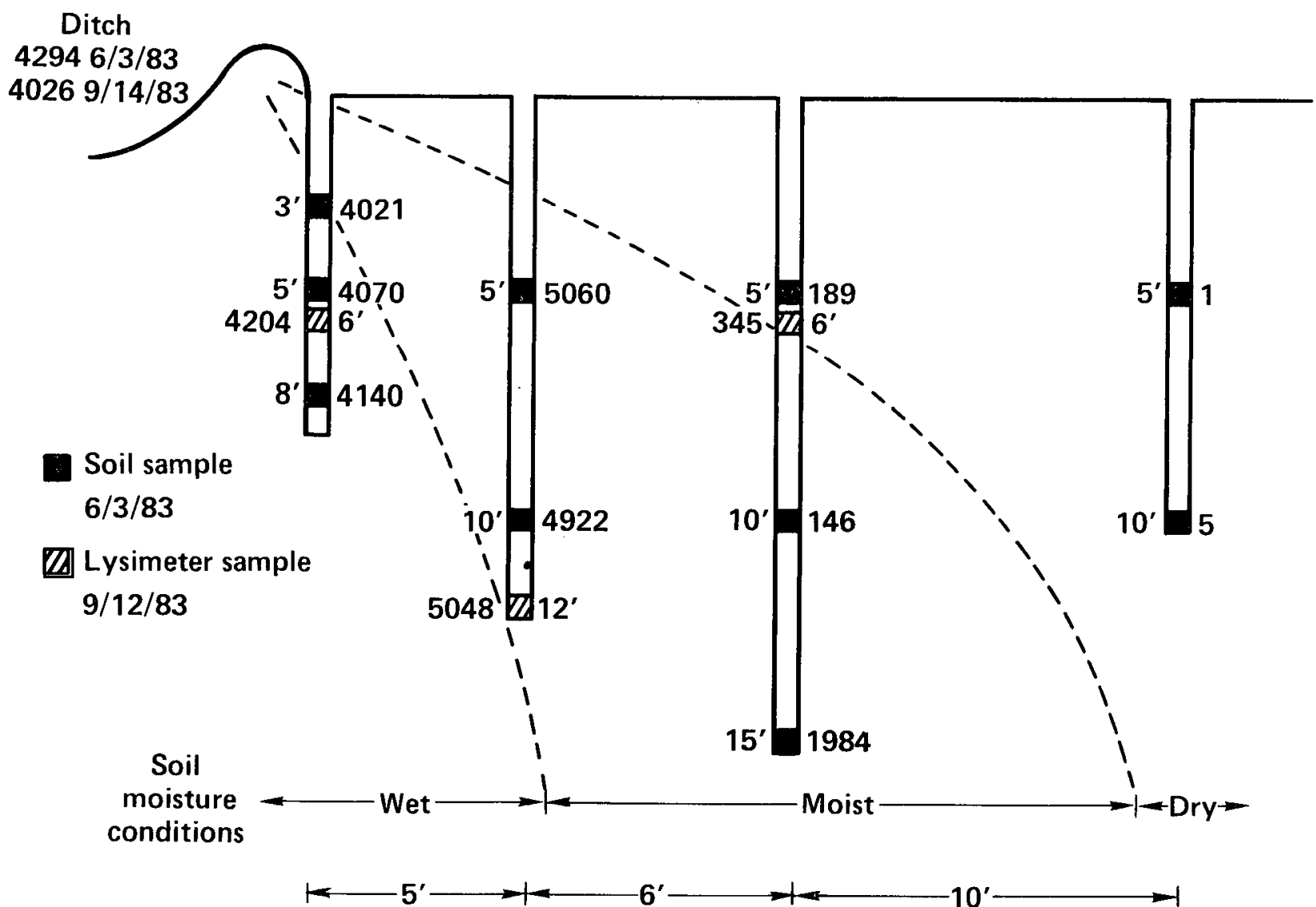

Figure 4-5. Soil core, lysimeter, and ditch ${ }^{3} \mathrm{H}$ activities $(\mathrm{dpm} / \mathrm{mL})$. 
front migrating through the soil column, and to use activities to determine transport rates. In addition to continued monitoring of these installations, we plan to slant-drill some holes into the presumably saturated zone beneath the ditch to determine stratigraphy and vertical flow rates, better define the shape of the plume to assist in calculating the rate and extent of recharge to the water table, and investigate the possibility of performing active field tracer experiments.

\subsection{References}

1. Jacobson, R., 1984, Desert Research Institute, Reno, NV, personal communication.

2. Daniels, W. R., and J. L. Thompson, 1984, Laboratory and Field Studies Related to the Radionuclide Migration Project, October 1, 1982 to September 30, 1983, Los Alamos National Laboratory, Los Alamos, NM, LANL Progress Report LA-10121-PR.

3. Thompson, J. L., 1984, “T Analysis of RNM-2S Water Samples," Los Alamos National Laboratory, Los Alamos, NM, LANL memorandum RNM-INC11-4/84-1 to RNM distribution.

4. Thompson, J. L., 1984, Desert Research Institute, Reno, NV, personal communication. 


\section{Geochemical Modeling Activities}

(Contributors: D. Isherwood and J. Rard)

\subsection{Introduction}

Ruthenium and technetium data bases were compiled for the EQ3/6 geochemical codes to study the potential for ruthenium and technetium migration from a nuclear explosion site. The ruthenium data base compiled for EQ3/6 was abstracted from Rard's 1985 critical review of ruthenium thermodynamic data. ${ }^{1}$ The 476 references listed by Rard contain essentially all of the thermodynamic data for ruthenium that were available in the literature at the time the document was written. The values recommended by Rard were used to create the data files for both solid phases and aqueous species. In all, 9 ruthenium solids and 26 aqueous species were included in the data base. The gases and liquids were omitted from the main EQ3/6 data base as they exist only at temperatures and conditions that are well outside the range of values for geochemical applications involving aqueous solutions. The technetium data base was created in a similar way using the 1983 compilation of technetium thermodynamic data by Rard. ${ }^{2}$ Thermodynamic data for 8 aqueous species and 15 solids were used to create the technetium data base. Copies of the ruthenium and technetium data files and a more detailed discussion of the modeling studies can be found in Ref. 3, which was authored by Isherwood. Wolery 4,5 describes the EQ3/6 code package, which is made up of two codes, EQ3NR and EQ6.

\subsection{The Cambric Site-A Field Study}

At the site of the Cambric nuclear test at NTS, a field study of radionuclide migration has been ongoing since 1975 . The Cambric device was detonated at a depth of $294 \mathrm{~m}$ in tuffaceous alluvium in May 1965. In 1974, two wells were drilled-one into the Cambric cavity region and a satellite well (RNM-2S) $91 \mathrm{~m}$ to the south. The objective of the study was to determine the potential for radionuclide migration from an underground nuclear test.

Pumping of the satellite well began in October 1975 and has continued since that time. No radioactivity was observed for the first two years.
With further pumping, tritium concentrations began to increase in samples from the satellite well and to decrease in the cavity. ${ }^{6}$ Attempts were made to measure radionuclides other than tritium using large-volume samples that were evaporated in the field using a distillation apparatus. ${ }^{106} \mathrm{Ru}$ and several other radionuclides were observed in the samples by Coles and Ramspott. ${ }^{7}$ The ${ }^{106} \mathrm{Ru} /$ ${ }^{3} \mathrm{H}$ ratios were nearly the same for all water samples from both wells. Coles and Ramspott suggest that ruthenium and tritium traveled at the same rate from the Cambric cavity to the satellite well. Their finding contradicts the prediction, based on laboratory sorption measurements, that ${ }^{106} \mathrm{Ru}$ would migrate at a slower rate than tritium.

\subsection{Geochemical Modeling of the Cambric Site}

The ruthenium data base was used with the EQ3NR geochemical code to evaluate the ruthenium geochemistry at the Cambric site. EQ3NR calculates from water analyses the distribution of ions, ion-pairs, and complexes and determines whether the water sample is saturated with various minerals. ${ }^{4}$ For this study, water analyses of samples taken from the satellite well (RNM-2S) were used as input to the code (see Table 5-1). Ruthenium was added as a component. Because the oxidation potential of the system is unknown, the system was assumed to be oxidizing ( $\mathrm{Eh}=$ $+0.8 \mathrm{~V}$ ) based on the work of Winograd and Robertson. ${ }^{8}$ They report that dissolved oxygen has been observed in a variety of aquifers in the south-central Great Basin, Nevada, and in all valley-fill aquifers in the southern Arizona portion of the Basin and Range Province.

Under oxidizing conditions, where the solid phase controlling solubility is $\mathrm{RuO}_{2}$, the calculated solubility limit is $2.1 \times 10^{-11} \mathrm{M}$. For comparison, a study of the effect of reducing conditions $(E \mathrm{Eh}=-0.1 \mathrm{~V})$ was also made. Under reducing conditions, the solubility $\left(1.5 \times 10^{-23} \mathrm{M}\right)$ is controlled by $\mathrm{Ru}(\mathrm{c})$. The $\mathrm{pH}$ also strongly controls ruthenium solubility (Fig. 5-1). For example, in oxidizing conditions, as the $\mathrm{pH}$ is lowered, the solubility decreases to a lower limit of $10^{-18} \mathrm{M}$ at $\mathrm{pH}=6.3$. Below that $\mathrm{pH}$ value, the solubility again increases and the dominant stable aqueous species becomes $\mathrm{Ru}(\mathrm{OH})_{2}^{++}$instead of $\mathrm{RuO}_{4}^{-}$. 
Table 5-1. Ground-water analyses for the Cambric site (RNM-2S).

\begin{tabular}{lc}
\hline Component & $\begin{array}{c}\mathrm{RNM}^{2 \mathrm{~S}^{\mathrm{a}}} \\
(\mathrm{mg} / \mathrm{L})\end{array}$ \\
\hline $\mathrm{Na}^{+}$ & 61 \\
$\mathrm{~K}^{+}$ & 9.9 \\
$\mathrm{Ca}^{++}$ & 18 \\
$\mathrm{Mg}^{++}$ & 5.5 \\
$\mathrm{Al}^{++}$ & $\mathrm{NA}^{\mathrm{b}}$ \\
$\mathrm{Fe}($ total $)$ & $\mathrm{NA}$ \\
$\mathrm{SiO}_{2}$ & 66 \\
$\mathrm{HCO}_{3}^{-}$ & 170 \\
$\mathrm{Cl}^{-}$ & 15 \\
$\mathrm{SO}_{4}^{--}$ & 40 \\
$\mathrm{~F}^{-}$ & 0.5 \\
$\mathrm{NO}_{3}^{-}$ & $\mathrm{NA}$ \\
$\mathrm{HPO}_{4}^{-}$ & $\mathrm{NA}$ \\
$\mathrm{pH}^{-}$ & 8.1 \\
$\mathrm{O}_{2}$ & $\mathrm{NA}$ \\
\hline
\end{tabular}

a Values shown are averages of analyses for samples taken from January to December 1982 provided by $L$. Benson (USGS).

b $\mathbf{N A}=$ net available.

How does the solubility limit calculated for the Cambric ground water compare with the ruthenium concentration in the cavity prior to pumping? To make this comparison, we must first make two assumptions: (1) the chemical composition of ground water in the satellite well represents the composition of ground water in the cavity well, and (2) the $\mathrm{pH}$ of the water in the cavity at approximately the depth of the perforations in the satellite well is also the same (i.e., 8.3).*

To calculate the total ruthenium content at the Cambric site, we must know the total of all ruthenium isotopes generated at the time of the nuclear detonation (Table 5-2). Based on the ${ }^{106} \mathrm{Ru}$ found in a sample collected from the bottom of the cavity $(8.3 \mathrm{dpm} / \mathrm{mL}$, which is equivalent to $3.4 \times 10^{-16} \mathrm{M}$ at $15 \mathrm{y}$ after detonation ${ }^{\dagger}$ ) and the percent of total ruthenium represented by the ${ }^{106} \mathrm{Ru}$ isotope $(0.0007 \%)$ also at $T=15 \mathrm{y}$, the concentration of ruthenium in solution is $4.5 \times$ $10^{-11} M$. The EQ3NR code predicts that ruthe-

* A second sample from the bottom of the cavity had $\mathrm{pH}=$ 11, but was apparently contaminated with drilling fluid (high calcium and lithium values were reported) and was not used in this evaluation.

t Fifteen years was chosen for comparison with the data reported by Coles and Ramspott. ${ }^{7}$

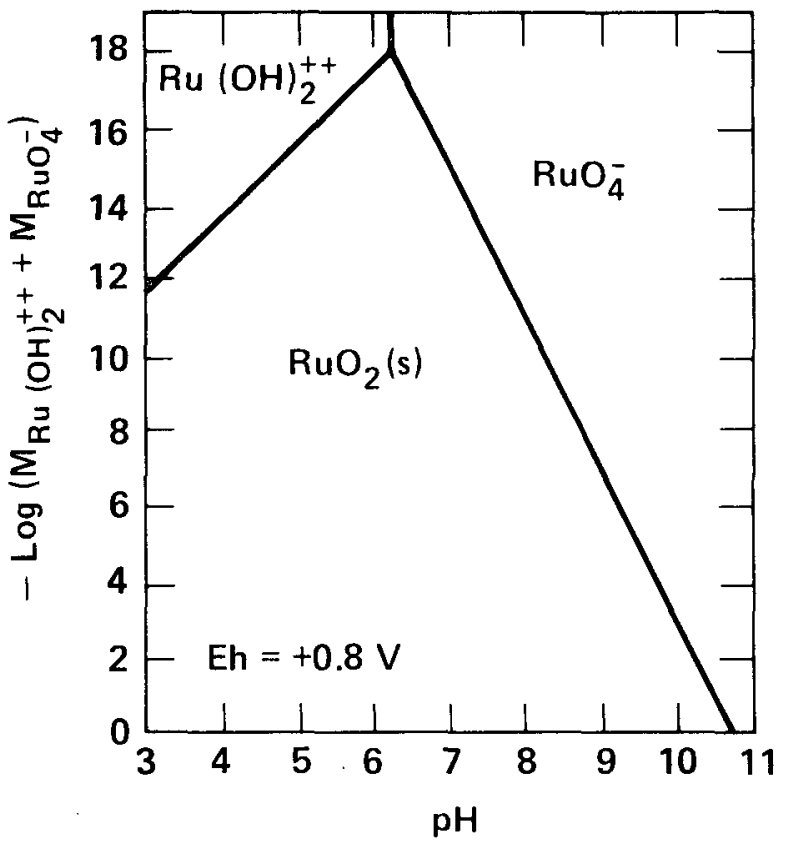

Figure 5-1. Plot drawn from calculations using successive runs of EQ3NR. Both the speciation and solubility of ruthenium are dependent on $\mathrm{pH}$.

nium solubility in an oxidizing environment where $\mathrm{RuO}_{2}$ in the stable solid phase is $2.1 \times$ $10^{-11} \mathrm{M}$. Given the uncertainties in the data base and the assumptions regarding the composition and $\mathrm{pH}$ of the cavity water, the two numbers are remarkably close.

The EQ3NR code predictions coincide with the field observations. The calculated ruthenium solubility matches the observed values when corrected for the presence of other ruthenium isotopes. The dominant aqueous ion, $\mathrm{RuO}_{4}^{-}$, is negatively charged and is therefore likely to migrate. Clues to the reasons for the apparent discrepancy between the laboratory and field measurements can be found in the Eh-pH diagrams.

\subsection{Ruthenium Eh-pH Diagrams}

To test the effect of oxidation potential or $\mathrm{pH}$ on speciation and solubility over a wide range of Eh-pH conditions, an Eh-pH diagram for the aqueous species of ruthenium was generated using a version of the code SOLUPLOT, a code designed to calculate and plot complex Eh-pH diagrams for systems with up to 35 aqueous species and solids containing a particular element. ${ }^{10}$ 
Table 5-2. Ruthenium isotopes generated at the Cambric Event. ${ }^{a}$

\begin{tabular}{lcccc}
\hline Isotope & Percent & Half-life & Atoms at $T=0$ & Atoms at $T=15 \mathrm{y}$ \\
\hline${ }^{101} \mathrm{Ru}$ & 6.75 & Stable & $8.1 \times 10^{21}$ & $8.1 \times 10^{21}$ \\
${ }^{102} \mathrm{Ru}$ & 6.65 & Stable & $8.0 \times 10^{21}$ & $8.0 \times 10^{21}$ \\
${ }^{104} \mathrm{Ru}$ & 5.86 & Stable & $7.0 \times 10^{21}$ & $7.0 \times 10^{21}$ \\
${ }^{106} \mathrm{Ru}$ & 4.64 & $357 \mathrm{~d}$ & $5.6 \times 10^{21}$ & $1.7 \times 10^{17}$ \\
\hline
\end{tabular}

a Yield $=0.75 \mathrm{kt}$.

${ }^{b}$ Isotope percentages are from Fleming. ${ }^{9}$ Because of their short half-lives, ruthenium isotopes 103, 105, 107, and 108 are not included in the calculations.

Figure 5-2 shows that the stability fields for the dominant aqueous ions are highly dependent on the concentration of ruthenium in solution as well as the Eh-pH of the system. The boundaries between positively and negatively charged species shift with changes in concentration. If the experimental conditions were at concentrations or $\mathrm{pH}$ 's different from those in the field, then one of the positively charged species shown in the diagrams could be dominant and sorption onto the solid would occur. The most likely species are $\mathrm{Ru}(\mathrm{OH})_{2}^{++}$and $\mathrm{Ru}_{4}(\mathrm{OH})_{12}^{4+}$.

As concentrations decrease, the stability field of the negatively charged ion $\mathrm{RuO}_{4}^{-}$increases. This may explain the migration of ruthenium, because the ruthenium becomes more dilute (and therefore more negatively charged) as water moves into and away from the cavity (assuming that negative ions migrate and positively charged ions are likely sorbed onto the rock). Kinetics could also affect the results of laboratory sorption experiments using ruthenium. For example, if the conversion of the positively charged to negatively charged species is slow relative to the time of the laboratory experiments, the decrease in concentration of the ruthenium remaining in solution as the positively charged ruthenium species is sorbed onto the solid phase would not favor the formation of $\mathrm{RuO}_{4}^{-}$. In this case, the laboratory conditions would not be representative of field conditions.

The interpretation of the results of the geochemical modeling relies heavily on theory and the reliability of the data base. Ruthenium experiments that combined leaching and sorption on crushed alluvium gave distribution coefficients $\left(K_{d}{ }^{\prime}\right)$ of 1000 to $3400 \mathrm{~mL} / \mathrm{g} .{ }^{11}$ Given the low solubility of ruthenium in the Cambric ground water, the $K_{d}$ 's could be a measure of precipitation rather than sorption. In a reducing environment $(E h=-0.1 \mathrm{~V})$, the solubility of ruthenium in the +3 oxidation state (i.e., $1.5 \times 10^{-23} \mathrm{M}$ ) is much less than in oxidizing conditions. The formation of positively charged ions could also be a contributing or a major factor. Given the complexity of ru- thenium chemistry, the geochemical models used in this study provide new answers, but not the only answers.

Like any model, the Eh-pH diagrams and the predicted solubilities and speciation using EQ3NR are based on the assumption that the total system is at equilibrium, that is, all couples shown on the Eh-pH diagram or considered in the EQ3NR calculations are in equilibrium with each other. Because of their dynamic nature, many natural systems do not achieve equilibrium. Models are also dependent on the number of species in the thermodynamic data base and on the quality of the data. Models are best used as an interpretive tool in combination with field and laboratory experience.

\subsection{Technetium Geochemistry}

Technetium solubilities were also calculated for the Cambric ground water using EQ3NR. In oxidizing conditions, the stable aqueous species is the pertechnetate ion, $\mathrm{TcO}_{4}^{-}$, and solubility is virtually unlimited. In a reducing environment $(\mathrm{Eh}=-0.1 \mathrm{~V})$, the calculated solubility is $1.8 \times$ $10^{-14} \mathrm{M}$ using $\mathrm{Tc}_{3} \mathrm{O}_{4}$ as the solubility constraint and $3.0 \times 10^{-8} \mathrm{M}$ using amorphous $\mathrm{TcO}_{2} \cdot 2 \mathrm{H}_{2} \mathrm{O}$. Based on the thermodynamic values compiled by Rard, ${ }^{2}$ EQ3NR predicts that the relatively insoluble $\mathrm{Tc}_{3} \mathrm{O}_{4}$ is the most stable oxide for a reduced form of technetium. However, laboratory studies of technetium have consistently given solubilities of approximately $10^{-5}$ to $10^{-8} \mathrm{M}$ in what were believed to be anoxic conditions. ${ }^{12,13}$ This suggests that a thermodynamically less stable form of technetium, possibly the amorphous $\mathrm{TcO}_{2} \cdot 2 \mathrm{H}_{2} \mathrm{O}$, controls technetium solubility-at least under laboratory conditions.

An Eh-pH diagram was created using the SOLUPLOT code to predict the dominant aqueous species of technetium present within the stability field of water [Fig. 5-3(a)]. Other aqueous species may be present in lesser amounts, but are 

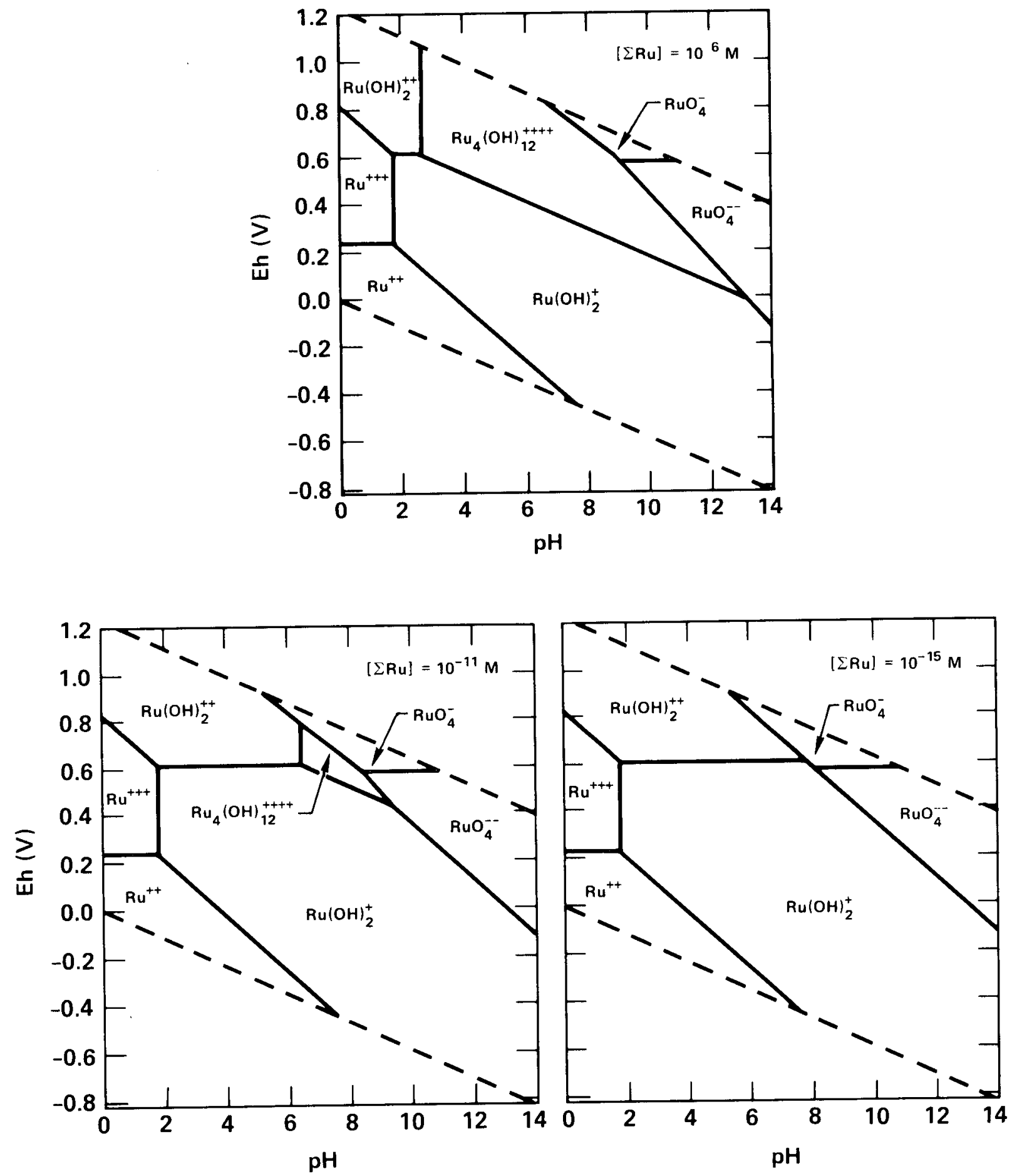

Figure 5-2. Eh-pH diagrams generated for aqueous species of ruthenium by SOLUPLOT. Solid phases are not shown. 

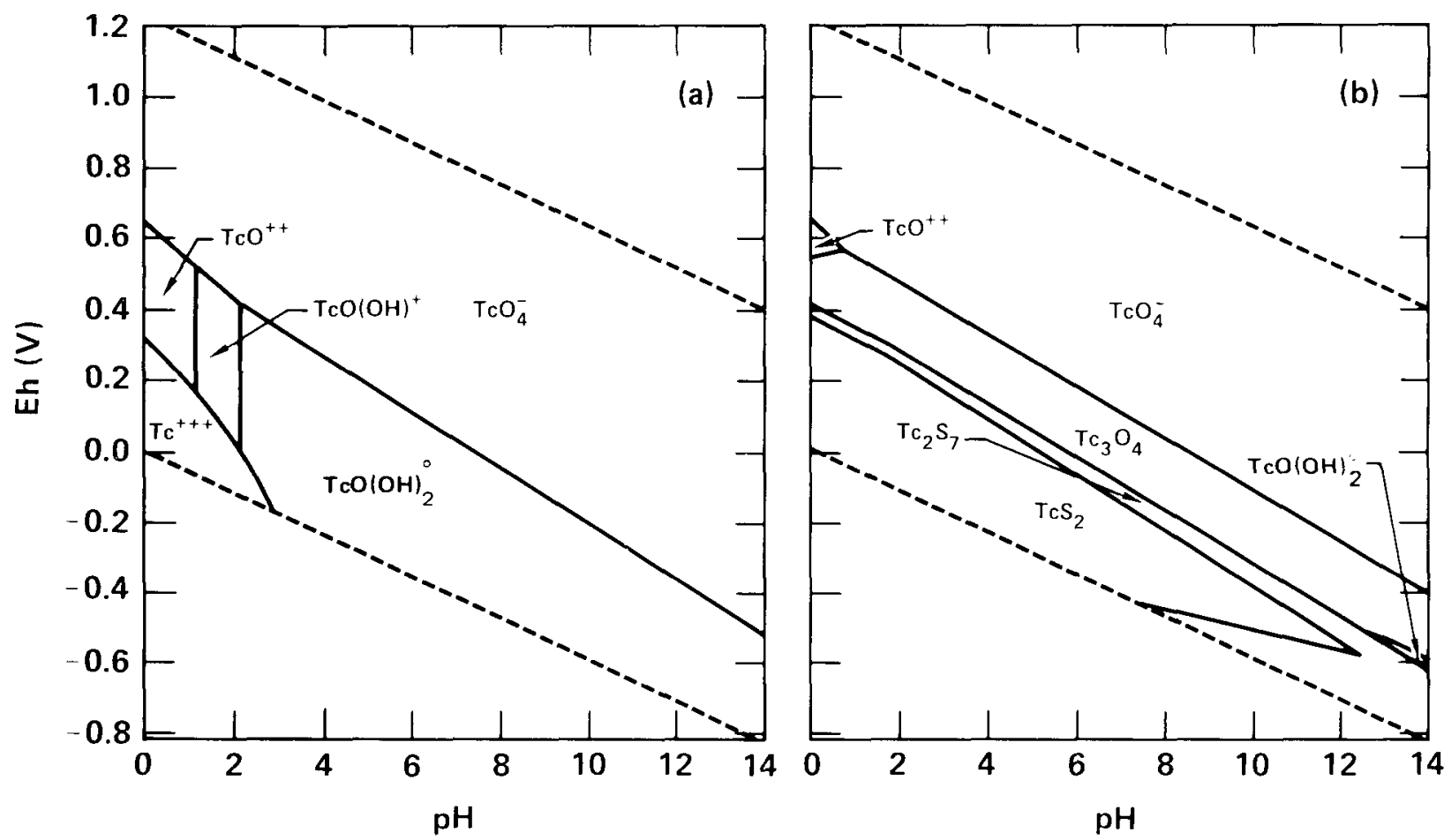

Figure 5-3. Eh-pH diagrams generated for technetium by SOLUPLOT. (a) Stability fields are shown only for the aqueous species of technetium. (b) Stability fields shown are for both aqueous and solid species at $\left[T_{\mathrm{c}}\right]=2.0 \times 10^{-7} \mathrm{M}$, the $\mathrm{MPC}_{\mathrm{w}}$ for ${ }^{99} \mathrm{Tc}$.

not shown on the Eh-pH diagram. In Fig. 5-3(b), the stability fields for both the aqueous and solid phases are indicated. The boundary between the stable aqueous phases (e.g., $\mathrm{TcO}_{4}^{-}$) and the solid phases is drawn where the concentration of technetium in solution $\left(2.0 \times 10^{-7} \mathrm{M}\right)$ equals the maximum concentration of ${ }^{99} \mathrm{Tc}$ in drinking water as permitted by the Federal Government (10CFR60 App. B). The $\mathrm{TCS}_{2}$ and $\mathrm{Tc}_{2} \mathrm{~S}_{7}$ stability fields shown in this diagram are a function of the amount of sulfate or sulfide present in the Cambric ground water. The Eh-pH diagram shown in Fig. 5-3(a) predicts that at equilibrium the dominant aqueous species of technetium will be $\mathrm{TcO}_{4}^{-}$in an oxidizing to moderately reducing environment within a $\mathrm{pH}$ range of approximately 3 to 14 . As the environment becomes more reducing, the concentration of technetium in solution is reduced and the dominant species is $\mathrm{TcO}(\mathrm{OH})_{2}^{\circ}$.

If ruthenium migrates, then technetium, which also exists as a negative ion in an oxidizing environment, should also migrate. Seven technetium isotopes are produced in a nuclear detonation. ${ }^{9}$ With the exception of ${ }^{99} \mathrm{Tc}$, none of the technetium isotopes have half-lives that would result in measurable concentrations given the time of the Cambric study. Approximately one-third as many ${ }^{99} \mathrm{Tc}$ atoms are produced as stable ruthe- nium atoms; however, technetium is not limited by solubility in an oxidizing environment and should be present, albeit in small concentrations. At the present time, the lack of sensitivity in our analytical techniques prevents the study of technetium migration. More sensitive methods are currently being developed by both LLNL and LANL, a coparticipant in the RNM Project. Until the archived samples from the cavity and satellite wells have been analyzed for technetium, we are limited to predictions using geochemical models.

\subsection{Summary}

Ruthenium migration at the Cambric site was successfully predicted by the model. The solubility of ruthenium in the cavity water was approximately equal to the predicted value. The negative ion predicted as the dominant species has potential for migration. The behavior of ruthenium in laboratory experiments that conflict with the observed behavior of ruthenium can be explained by differences in speciation between laboratory and field conditions. When analytical techniques are improved, there is hope that technetium migration may yet be measured at the Cambric site. 


\subsection{References}

1. Rard, J., 1985, "Chemistry and Thermodynamics of Ruthenium and Some of Its Inorganic Compounds and Aqueous Species," Chemical Reviews 85, pp. 1-39.

2. Rard, J., 1983, Critical Review of the Chemistry and Thermodynamics of Technetium and Some of its Inorganic Compounds and Aqueous Species, Lawrence Livermore National Laboratory, Livermore, CA, UCRL-53440.

3. Isherwood, D., 1985, Application of the Ruthenium and Technetium Thermodynamic Data Bases Used in the EQ3/6 Geochemical Codes, Lawrence Livermore National Laboratory, Livermore, CA, UCRL53594.

4. Wolery, T., 1983, EQ3NR: A Computer Program for Geochemical Aqueous Speciation-Solubility Calculations: User's Guide and Documentation, Lawrence Livermore National Laboratory, Livermore, CA, UCRL-53414.

5. Wolery, T., 1985, EQ6, A Computer Program for Reaction-Path Modeling of Aqueous Geochemical Systems: User's Guide and Documentation, Lawrence Livermore National Laboratory, Livermore, CA, UCRL-in review.

6. Hoffman, D., R. Stone, and W. Dudley, Jr., 1977, Radioactivity in the Underground Environment of the Cambric Nuclear Explosion at the Nevada Test Site, Los Alamos National Laboratory, Los Alamos, NM, LA-6788-MS.

7. Coles, D., and L. Ramspott, 1982, "Migration of Ruthenium-106 in a Nevada Test Site Aquifer: Discrepancy Between Field and Laboratory Results," Science 215, pp. 1235-1237.

8. Winograd, I., and F. Robertson, 1982, "Deep Oxygenated Ground Water: Anomaly or Common Occurrence?," Science 216, pp. 1227-1230.

9. Fleming, E., 1967, Fission Product Decay Chains $\left({ }^{239} \mathrm{Pu}\right.$ with Fission Spectrum Neutrons), Lawrence Livermore National Laboratory, Livermore, CA, UCRL-50243, vol. 1.

10. Bethke, C., 1978, Program SOLUPLOT-a FORTRAN Program To Calculate and Plot Equilibrium Eh- $p H$ and $\log a_{O_{2}}-p H$ Diagrams for Chemical Systems, Pennsylvania State University, University Park, PA (unpublished thesis).

11. Wolfsberg, K., 1978, Sorption-Desorption Studies of Nevada Test Site Alluvium and Leaching Studies of Nuclear Test Debris, Los Alamos National Laboratory, Los Almos, NM, LA-7216-MS.

12. Kelmers, A., R. Clark, N. Cutshall, G. Jacobs, J. Johnson, J. Kessler, and R. Meyer, 1984, Evaluation of Radiochemical Information Developed by DOE High-Level Nuclear Waste Repository Site Projects, Nuclear Regulatory Commission, NUREG/CR-3730 (ORNL/TM-9109).

13. Kelmers, A., J. Kessler, W. Arnold, R. Meyer, N. Cutshall, G. Jacobs, and S. Less, 1984, Progress in Evaluation of Radionuclide Information Developed by DOE High-Level Waste Repository Projects: Report for October-December 1983, Nuclear Regulatory Commission, NUREG-CR-3851, vol. 1 (ORNL/TM-9191/VI).

\section{NMS,JCC/jlc}




\section{Appendix A Analytical Methods}

This section describes the sample collection, processing, and analytical methods generally used for the RNM well samples. Unique or highly specific methods are described in the appropriate sections.

The salt samples obtained from the evaporation of large-volume water samples (Section 2.1.1) are transferred to a tared container of standard geometry, sealed, weighed, and counted for at least a week on low-background $\mathrm{Ge}(\mathrm{Li})$ detector systems. The spectrum is analyzed and results calculated by the GAMANAL computer code ${ }^{1,2}$ Disk-type filters (e.g., Nuclepore), when used, are counted in a similar fashion. Cartridge or bag filters are cut up and the pieces pressed into the standard containers before sealing and counting. The results are calculated on the basis of the volume of the original water sample. The uncertainties reported are based on counting statistics as calculated by the GAMANAL code; these do not represent the true experimental uncertainties for possibly heterogeneous samples counted in an extended geometry. Based on laboratory trials, the estimated minimum uncertainties are $10-20 \%$ for salt samples and $20-30 \%$ for filters.

High-activity (chimney or cavity) samples are sometimes counted directly by placing a known aliquot of the water into a standard volume container (Marinelli beaker or Prindle vial).

Tritium analyses are performed by direct liquid scintillation counting of the water sample. The methods employed have been developed and standardized for our environmental tritium laboratory. ${ }^{1-3}$

During 1983 and 1984, we have systematically developed and standardized our chemical analytical capabilities. We now routinely analyze water samples for the major and minor ionic constituents and, when possible, for standard water quality parameters in the field. Stable cations are analyzed at LLNL by inductively coupled plasma-optical emission spectrometry (ICP-OES) techniques. ${ }^{1-4}$ Anions are analyzed either by ion chromatography or autoanalyzer techniques according to procedures developed and maintained by LLNL's Chemistry Department. In the field, prompt analyses are performed for $\mathrm{pH}$ and Eh (data reported vs Normal Hydrogen Electrode) using Orion $\mathrm{pH} /$ millivoltmeters and appropriate electrodes, for dissolved oxygen using a Leeds and Northrup DO meter, and for alkalinity, hardness, and sulfides using a Hach field titration kit.

In all cases, care is taken to avoid sample contamination, and all analyses are carried out by calibrated standard methods according to the quality assurance standards adopted by the appropriate LLNL organization.

\section{References}

1. Camp, D. C., C. Gatrousis, and L. A. Maynard, 1974, "Low Background Ge(Li) Detector Systems for Radioenvironmental Studies," Nucl. Instrum. Meth. 117, 189.

2. Gunnink, R., and J. B. Niday, 1974, Computerized Quantitative Analysis by Gamma-Ray Spectrometry, Lawrence Livermore National Laboratory, Livermore, CA, UCRL-51061.

3. Reed, D., A. L. Gazelay, A. Connover, J. A. Bazan, M. R. Ruggieri, D. W. Hosmer, and R. W. Buddemeier, 1981, Radiochemical Methods of the Site Environmental Monitoring Program, Lawrence Livermore National Laboratory, Livermore, CA, M-122.

4. Peck, E. S., A. L. Langhorst, and D. W. O'Brien, 1979, Analysis of Natural Waters with an Inductively Coupled Plasma Spectrometer System, Lawrence Livermore National Laboratory, Livermore, CA, UCRL-81043. 


\section{Appendix B Soil Moisture Data}

Table B1 presents the field data obtained from the soil moisture instrumentation for the Cambric plume study. See Section 4 for a description of the project and experimental site. The key for the table is as follows:

First column: Type of soil moisture instrument. $\mathrm{RC}=$ resistance cell, $\mathrm{NP}=$ neutron probe, $\mathrm{T}=$ tensiometer.

Second column: Date. First two digits are year, last three are day of year.

Third column: Sample\# identifies the instrument by number, distance from the berm of the ditch, and depth beneath ground surface. Example: 13,14-5-11 designates resistance cells 13 and 14, both of which are $5 \mathrm{ft}$ from the outer edge of the berm and $11 \mathrm{ft}$ below the surface (see Figs. 4-2 and 4-3). Resistance cells and tensiometers were installed in pairs at each distance and depth; where only one number appears in the first block, it indicates that one of the instruments was not operating.

Fourth column: Reading of instrument (numerical value); where pairs of instruments are operating, the reading reported is the mean of the two readings.

Fifth column: Units of instrument reading-ohms for resistance cells, volume \% moisture for the neutron probe, and centibars of soil moisture tension for the tensiometers.

This table has not been edited by comparison with field notes to eliminate readings that may reflect instrument problems or unusual environmental conditions. In particular, many of the neutron probe observations are suspect. "Stars" indicate cases where no reading was obtained (e.g., tensiometers frozen in winter). The authors request that anyone contemplating use or interpretation of these data contact them for a more complete discussion of their significance.

Table B-1. Field data from soil moisture instrumentation for the Cambric plume study.

\begin{tabular}{|c|c|c|c|c|}
\hline Type & Date & Sample\# & Reading & Units \\
\hline $\mathrm{RC}$ & 83192 & $13,14-5-11$ & 7750 & ohms \\
\hline $\mathrm{RC}$ & 83200 & $13,14-5-11$ & 6900 & ohms \\
\hline $\mathrm{RC}$ & 83206 & $13,14-5-11$ & 6700 & ohms \\
\hline $\mathrm{RC}$ & 83213 & $13,14-5-11$ & 6700 & ohms \\
\hline $\mathrm{RC}$ & 83220 & $13,14-5-11$ & 6250 & ohms \\
\hline RC & 83227 & $13,14-5-11$ & 6050 & ohms \\
\hline $\mathrm{RC}$ & 83241 & $13,14-5-11$ & 6000 & ohms \\
\hline RC & 83250 & $13,14-5-11$ & 6000 & ohms \\
\hline $\mathbf{R C}$ & 83255 & $13,14-5-11$ & 6000 & ohms \\
\hline $\mathrm{RC}$ & 83262 & $13,14-5-11$ & 6100 & ohms \\
\hline $\mathrm{RC}$ & 83271 & $13,14-5-11$ & 6100 & ohms \\
\hline $\mathrm{RC}$ & 83283 & $13,14-5-11$ & 6150 & ohms \\
\hline RC & 83297 & $13,14-5-11$ & 6150 & ohms \\
\hline RC & 83305 & $13,14-5-11$ & 6400 & ohms \\
\hline RC & 83311 & $13,14-5-11$ & 5900 & ohms \\
\hline RC & 83318 & $13,14-5-11$ & 6100 & ohms \\
\hline $\mathrm{RC}$ & 83325 & $13,14-5-11$ & 5850 & ohms \\
\hline $\mathrm{RC}$ & 83332 & $13,14-5-11$ & 6150 & ohms \\
\hline $\mathbf{R C}$ & 83339 & $13,14-5-11$ & 6250 & ohms \\
\hline RC & 83346 & $13,14-5-11$ & 6250 & ohms \\
\hline $\mathbf{R C}$ & 83353 & $13,14-5-11$ & 6250 & ohms \\
\hline$R C$ & 83361 & $13,14-5-11$ & 6200 & ohms \\
\hline $\mathrm{RC}$ & 84003 & $13,14-5-11$ & 6350 & ohms \\
\hline RC & 84009 & $13,14-5-11$ & 6350 & ohms \\
\hline RC & 84016 & $13,14-5-11$ & 6350 & ohms \\
\hline $\mathrm{RC}$ & 84030 & $13,14-5-11$ & 6700 & ohms \\
\hline $\mathrm{RC}$ & 84037 & $13,14-5-11$ & 6500 & ohms \\
\hline
\end{tabular}

Table B-1. Continued.

\begin{tabular}{lllll}
\hline Type & Date & Sample\# & Reading & Units \\
\hline RC & 84044 & $13,14-5-11$ & 7000 & ohms \\
RC & 84052 & $13,14-5-11$ & 6950 & ohms \\
RC & 84058 & $13,14-5-11$ & 7150 & ohms \\
RC & 84065 & $13,14-5-11$ & 7150 & ohms \\
RC & 84072 & $13,14-5-11$ & 6950 & ohms \\
RC & 84079 & $13,14-5-11$ & 7100 & ohms \\
RC & 84086 & $13,14-5-11$ & 7200 & ohms \\
RC & 84093 & $13,14-5-11$ & 7200 & ohms \\
RC & 84100 & $13,14-5-11$ & 7250 & ohms \\
RC & 84107 & $13,14-5-11$ & 7100 & ohms \\
RC & 84114 & $13,14-5-11$ & 7350 & ohms \\
RC & 84121 & $13,14-5-11$ & 7800 & ohms \\
RC & 84128 & $13,14-5-11$ & 7650 & ohms \\
RC & 84135 & $13,14-5-11$ & 7300 & ohms \\
RC & 84142 & $13,14-5-11$ & 7500 & ohms \\
RC & 84151 & $13,14-5-11$ & 7300 & ohms \\
RC & 84156 & $13,14-5-11$ & 7250 & ohms \\
RC & 84163 & $13,14-5-11$ & 7250 & ohms \\
RC & 84170 & $13,14-5-11$ & 7350 & ohms \\
RC & 84177 & $13,14-5-11$ & 7250 & ohms \\
RC & 84184 & $13,14-5-11$ & 7100 & ohms \\
RC & 84191 & $13,14-5-11$ & 7250 & ohms \\
RC & 84198 & $13,14-5-11$ & 7400 & ohms \\
RC & 84205 & $13,14-5-11$ & 7400 & ohms \\
RC & 84212 & $13,14-5-11$ & 7800 & ohms \\
RC & 84219 & $13,14-5-11$ & 7400 & ohms \\
RC & 84226 & $13,14-5-11$ & 6350 & ohms
\end{tabular}


Table B-1. Continued.

\begin{tabular}{|c|c|c|c|c|c|c|c|c|c|}
\hline Type & Date & Sample\# & Reading & Units & Type & Date & Sample\# & Reading & Units \\
\hline $\mathrm{RC}$ & 83192 & $22-5-5$ & 7000 & ohms & RC & 83255 & $15,16-11-11$ & 3700 & ohms \\
\hline RC & 83200 & $22-5-5$ & 6800 & ohms & $\mathrm{RC}$ & 83262 & $15,16-11-11$ & 3450 & ohms \\
\hline RC & 83206 & $22-5-5$ & 6000 & ohms & RC & 83271 & $15,16-11-11$ & 3150 & ohms \\
\hline RC & 83213 & $22-5-5$ & 6000 & ohms & RC & 83283 & $15,16-11-11$ & 3100 & ohms \\
\hline $\mathrm{RC}$ & 83220 & $22-5-5$ & 6000 & ohms & $\mathrm{RC}$ & 83297 & $15,16-11-11$ & 3100 & ohms \\
\hline RC & 83227 & $22-5-5$ & 5500 & ohms & RC & 83305 & $15,16-11-11$ & 3050 & ohms \\
\hline $\mathbf{R C}$ & 83241 & $22-5-5$ & 3500 & ohms & $\mathrm{RC}$ & 83311 & $15,16-11-11$ & 3000 & ohms \\
\hline RC & 83250 & $22-5-5$ & 3300 & ohms & RC & 83318 & $15,16-11-11$ & 3000 & ohms \\
\hline $\mathrm{RC}$ & 83255 & $22-5-5$ & 3300 & ohms & RC & 83325 & $15,16-11-11$ & 2900 & ohms \\
\hline $\mathrm{RC}$ & 83262 & $22-5-5$ & 3200 & ohms & $\mathrm{RC}$ & 83332 & $15,16-11-11$ & 2900 & ohms \\
\hline RC & 83271 & $22-5-5$ & 3300 & ohms & RC & 83339 & $15,16-11-11$ & 2900 & ohms \\
\hline $\mathrm{RC}$ & 83283 & $22-5-5$ & 3400 & ohms & RC & 83346 & $15,16-11-11$ & 2900 & ohms \\
\hline RC & 83297 & $22-5-5$ & 3400 & ohms & RC & 83353 & $15,16-11-11$ & 2900 & ohms \\
\hline $\mathrm{RC}$ & 83305 & $22-5-5$ & 3200 & ohms & RC & 83361 & $15,16-11-11$ & 2900 & ohms \\
\hline RC & 83311 & $22-5-5$ & 3200 & ohms & RC & 84003 & $15,16-11-11$ & 2900 & ohms \\
\hline $\mathrm{RC}$ & 83318 & $22-5-5$ & 3200 & ohms & RC & 84009 & $15,16-11-11$ & 2900 & ohms \\
\hline RC & 83325 & $22-5-5$ & 3200 & ohms & RC & 84016 & $15,16-11-11$ & 2900 & ohms \\
\hline $\mathrm{RC}$ & 83332 & $22-5-5$ & 3400 & ohms & RC & 84030 & $15,16-11-11$ & 3150 & ohms \\
\hline RC & 83339 & $22-5-5$ & 3400 & ohms & RC & 84037 & $15,16-11-11$ & 3000 & ohms \\
\hline RC & 83346 & $22-5-5$ & 3500 & ohms & RC & 84044 & $15,16-11-11$ & 3050 & ohms \\
\hline $\mathrm{RC}$ & 83353 & $22-5-5$ & 3500 & ohms & RC & 84052 & $15,16-11-11$ & 3000 & ohms \\
\hline RC & 83361 & $22-5-5$ & 3600 & ohms & RC & 84058 & $15,16-11-11$ & 3050 & ohms \\
\hline RC & 84003 & $22-5-5$ & 3600 & ohms & RC & 84065 & $15,16-11-11$ & 3100 & ohms \\
\hline RC & 84009 & $22-5-5$ & 3500 & ohms & $R C$ & 84072 & $15,16-11-11$ & 2950 & ohms \\
\hline RC & 84016 & $22-5-5$ & 3600 & ohms & RC & 84079 & $15,16-11-11$ & 3050 & ohms \\
\hline RC & 84030 & $22-5-5$ & 3700 & ohms & $\mathrm{RC}$ & 84086 & $15,16-11-11$ & 3100 & ohms \\
\hline $\mathrm{RC}$ & 84037 & $22-5-5$ & 3500 & ohms & RC & 84093 & $15,16-11-11$ & 3000 & ohms \\
\hline RC & 84044 & $22-5-5$ & 3600 & ohms & $\mathrm{RC}$ & 84100 & $15,16-11-11$ & 3300 & ohms \\
\hline RC & 84052 & $22-5-5$ & 3600 & ohms & RC & 84107 & $15,16-11-11$ & 3000 & ohms \\
\hline RC & 84058 & $22-5-5$ & 3600 & ohms & RC & 84114 & $15,16-11-11$ & 3000 & ohms \\
\hline $\mathrm{RC}$ & 84065 & $22-5-5$ & 3500 & ohms & RC & 84121 & $15,16-11-11$ & 3000 & ohms \\
\hline RC & 84072 & $22-5-5$ & 3500 & ohms & RC & 84128 & $15,16-11-11$ & 3000 & ohms \\
\hline RC & 84079 & $22-5-5$ & 3400 & ohms & RC & 84135 & $15,16-11-11$ & 3000 & ohms \\
\hline RC & 84086 & $22-5-5$ & 3400 & ohms & RC & 84142 & $15,16-11-11$ & 2950 & ohms \\
\hline $\mathrm{RC}$ & 84093 & $22-5-5$ & 3200 & ohms & $\mathrm{RC}$ & 84151 & $15,16-11-11$ & 2950 & ohms \\
\hline RC & 84100 & $22-5-5$ & 3400 & ohms & RC & 84156 & $15,16-11-11$ & 2900 & ohms \\
\hline $\mathrm{RC}$ & 84107 & $22-5-5$ & 3500 & ohms & RC & 84163 & $15,16-11-11$ & 2800 & ohms \\
\hline $\mathrm{RC}$ & 84114 & $22-5-5$ & 3500 & ohms & RC & 84170 & $15,16-11-11$ & 2850 & ohms \\
\hline RC & 84121 & $22-5-5$ & 3500 & ohms & RC & 84177 & $15,16-11-11$ & 2800 & ohms \\
\hline $\mathrm{RC}$ & 84128 & $22-5-5$ & 3500 & ohms & RC & 84184 & $15,16-11-11$ & 2600 & ohms \\
\hline RC & 84135 & $22-5-5$ & 3200 & ohms & RC & 84191 & $15,16-11-11$ & 2750 & ohms \\
\hline $\mathrm{RC}$ & 84142 & $22-5-5$ & 3000 & ohms & RC & 84198 & $15,16-11-11$ & 2800 & ohms \\
\hline $\mathrm{RC}$ & 84151 & $22-5-5$ & 3000 & ohms & RC & 84205 & $15,16-11-11$ & 2800 & ohms \\
\hline $\mathrm{RC}$ & 84156 & $22-5-5$ & 2800 & ohms & RC & 84212 & $15,16-11-11$ & 2700 & ohms \\
\hline RC & 84163 & $22-5-5$ & 2800 & ohms & RC & 84219 & $15,16-11-11$ & 2700 & ohms \\
\hline RC & 84170 & $22-5-5$ & 2800 & ohms & RC & 84226 & $15,16-11-11$ & 2650 & ohms \\
\hline RC & 84177 & $22-5-5$ & 2800 & ohms & RC & 83192 & $18,19-11-5$ & 112500 & ohms \\
\hline RC & 84184 & $22-5-5$ & 2700 & ohms & RC & 83200 & $18,19-11-5$ & 105000 & ohms \\
\hline $\mathrm{RC}$ & 84191 & $22-5-5$ & 2300 & ohms & RC & 83206 & $18,19-11-5$ & 95000 & ohms \\
\hline RC & 84198 & $22-5-5$ & 2700 & ohms & RC & 83213 & $18,19-11-5$ & 90000 & ohms \\
\hline $\mathrm{RC}$ & 84205 & $22-5-5$ & 2700 & ohms & RC & 83220 & $18,19-11-5$ & 82500 & ohms \\
\hline $\mathrm{RC}$ & 84212 & $22-5-5$ & 2500 & ohms & RC & 83227 & $18,19-11-5$ & 110000 & ohms \\
\hline RC & 84219 & $22-5-5$ & 2500 & ohms & RC & 83241 & $18,19-11-5$ & 74000 & ohms \\
\hline $\mathrm{RC}$ & 84226 & $22-5-5$ & 2400 & ohms & RC & 83250 & $18,19-11-5$ & 72500 & ohms \\
\hline RC & 83192 & $15,16-11-11$ & 20400 & ohms & RC & 83255 & $18,19-11-5$ & 72500 & ohms \\
\hline $\mathrm{RC}$ & 83200 & $15,16-11-11$ & 11650 & ohms & RC & 83262 & $18,19-11-5$ & 67000 & ohms \\
\hline $\mathrm{RC}$ & 83206 & $15,16-11-11$ & 10400 & ohms & RC & 83271 & $18,19-11-5$ & 67500 & ohms \\
\hline RC & 83213 & $15,16-11-11$ & 6550 & ohms & RC & 83283 & $18,19-11-5$ & 67500 & ohms \\
\hline $\mathrm{RC}$ & 83220 & $15,16-11-11$ & 6250 & ohms & RC & 83297 & $18,19-11-5$ & 65000 & ohms \\
\hline RC & 83227 & $15,16-11-11$ & 4800 & ohms & RC & 83305 & $18,19-11-5$ & 62000 & ohms \\
\hline RC & 83241 & $15,16-11-11$ & 3950 & ohms & RC & 83311 & $18,19-11-5$ & 64500 & ohms \\
\hline $\mathrm{RC}$ & 83250 & $15,16-11-11$ & 3750 & ohms & RC & 83318 & $18,19-11-5$ & 62000 & ohms \\
\hline
\end{tabular}

Table B-1. Continued. 
Table B-1. Continued.

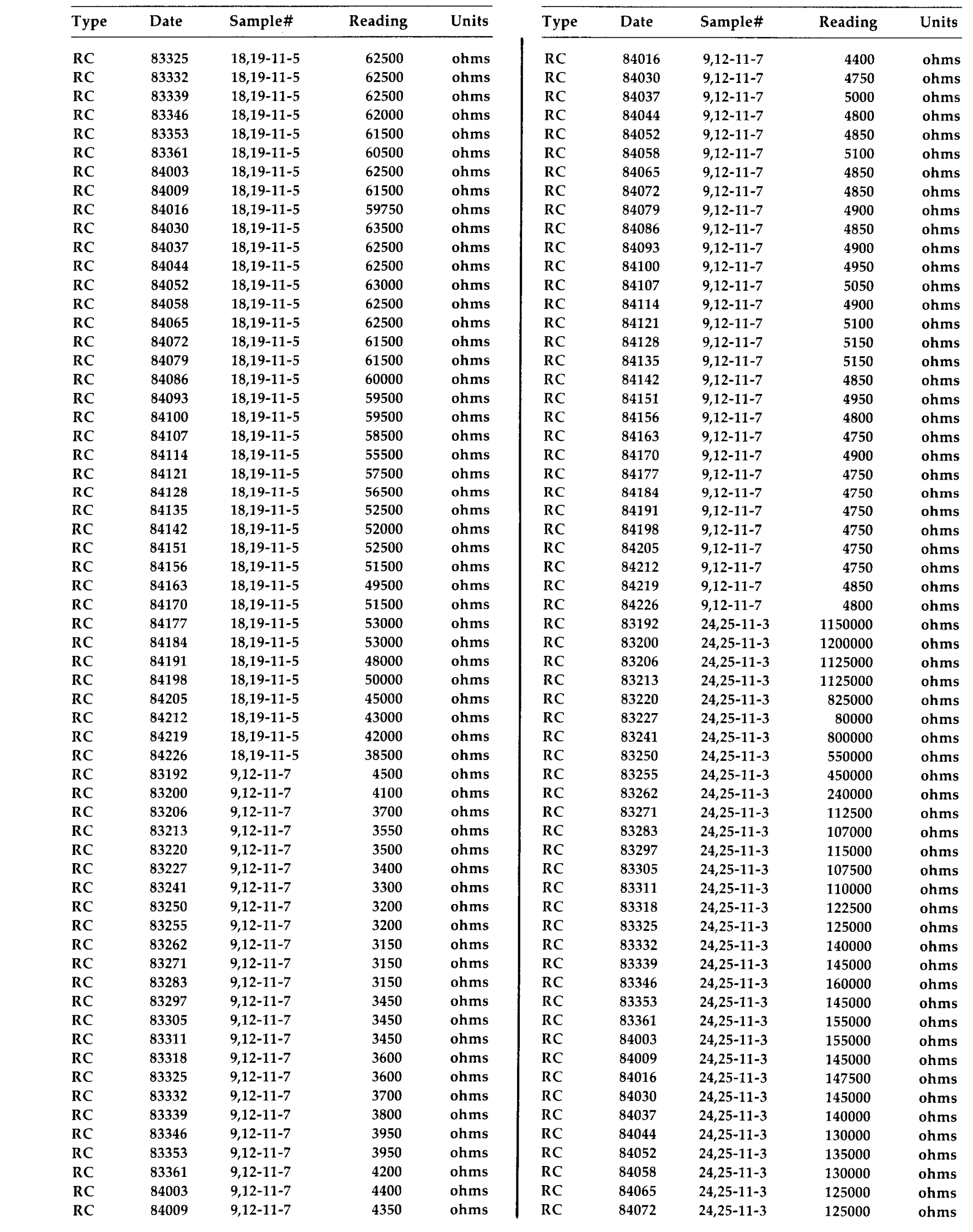

Table B-1. Continued.

Table B-1. Continued.


Table B-1. Continued.

\begin{tabular}{|c|c|c|c|}
\hline Type & Date & Sample\# & Reading \\
\hline RC & 84079 & $24,25-11-3$ & 112500 \\
\hline RC & 84086 & $24,25-11-3$ & 110000 \\
\hline $\mathrm{RC}$ & 84093 & $24,25-11-3$ & 109000 \\
\hline $\mathrm{RC}$ & 84100 & $24,25-11-3$ & 104000 \\
\hline RC & 84107 & $24,25-11-3$ & 94000 \\
\hline RC & 84114 & $24,25-11-3$ & 95000 \\
\hline $\mathrm{RC}$ & 84121 & $24,25-11-3$ & 95000 \\
\hline RC & 84128 & $24,25-11-3$ & 94000 \\
\hline $\mathrm{RC}$ & 84135 & $24,25-11-3$ & 86500 \\
\hline RC & 84142 & $24,25-11-3$ & 86000 \\
\hline RC & 84151 & $24,25-11-3$ & 83500 \\
\hline$R C$ & 84156 & $24,25-11-3$ & 89000 \\
\hline RC & 84163 & $24,25-11-3$ & 94000 \\
\hline $\mathrm{RC}$ & 84170 & $24,25-11-3$ & 102500 \\
\hline $\mathrm{RC}$ & 84177 & $24,25-11-3$ & 110000 \\
\hline RC & 84184 & $24,25-11-3$ & 115000 \\
\hline $\mathrm{RC}$ & 84191 & $24,25-11-3$ & 120000 \\
\hline RC & 84198 & $24,25-11-3$ & 117500 \\
\hline $\mathrm{RC}$ & 84205 & $24,25-11-3$ & 117500 \\
\hline $\mathrm{RC}$ & 84212 & $24,25-11-3$ & 110000 \\
\hline RC & 84219 & $24,25-11-3$ & 105000 \\
\hline $\mathrm{RC}$ & 84226 & $24,25-11-3$ & 96000 \\
\hline $\mathrm{RC}$ & 83192 & $17,20-21-4$ & 1400000 \\
\hline $\mathrm{RC}$ & 83200 & $17,20-21-4$ & 1600000 \\
\hline RC & 83206 & $17,20-21-4$ & 1750000 \\
\hline $\mathrm{RC}$ & 83213 & $17,20-21-4$ & 1750000 \\
\hline RC & 83220 & $17,20-21-4$ & 750000 \\
\hline $\mathrm{RC}$ & 83227 & $17,20-21-4$ & 750000 \\
\hline $\mathrm{RC}$ & 83241 & $17,20-21-4$ & 1500000 \\
\hline $\mathrm{RC}$ & 83250 & $17,20-21-4$ & 1750000 \\
\hline $\mathrm{RC}$ & 83255 & $17,20-21-4$ & 1500000 \\
\hline $\mathrm{RC}$ & 83262 & $17,20-21-4$ & 1250000 \\
\hline $\mathrm{RC}$ & 83271 & $17,20-21-4$ & 1250000 \\
\hline $\mathrm{RC}$ & 83283 & $17,20-21-4$ & 1500000 \\
\hline $\mathrm{RC}$ & 83297 & $17,20-21-4$ & 1500000 \\
\hline $\mathrm{RC}$ & 83305 & $17,20-21-4$ & 1250000 \\
\hline $\mathrm{RC}$ & 83311 & $17,20-21-4$ & 1250000 \\
\hline $\mathbf{R C}$ & 83318 & $17,20-21-4$ & 1250000 \\
\hline $\mathrm{RC}$ & 83325 & $17,20-21-4$ & 900000 \\
\hline $\mathbf{R C}$ & 83332 & $17,20-21-4$ & 875000 \\
\hline RC & 83339 & $17,20-21-4$ & 900000 \\
\hline $\mathrm{RC}$ & 83346 & $17,20-21-4$ & 900000 \\
\hline $\mathrm{RC}$ & 83353 & $17,20-21-4$ & 875000 \\
\hline $\mathrm{RC}$ & 83361 & $17,20-21-4$ & 1000000 \\
\hline RC & 84003 & $17,20-21-4$ & 875000 \\
\hline $\mathrm{RC}$ & 84009 & $17,20-21-4$ & 1125000 \\
\hline $\mathbf{R C}$ & 84016 & $17,20-21-4$ & 875000 \\
\hline $\mathrm{RC}$ & 84030 & $17,20-21-4$ & 1250000 \\
\hline $\mathrm{RC}$ & 84037 & $17,20-21-4$ & 1000000 \\
\hline $\mathrm{RC}$ & 84044 & $17,20-21-4$ & 1200000 \\
\hline $\mathrm{RC}$ & 84052 & $17,20-21-4$ & 1050000 \\
\hline $\mathrm{RC}$ & 84058 & $17,20-21-4$ & 1200000 \\
\hline $\mathrm{RC}$ & 84065 & $17,20-21-4$ & 875000 \\
\hline $\mathrm{RC}$ & 84072 & $17,20-21-4$ & 875000 \\
\hline $\mathrm{RC}$ & 84079 & $17,20-21-4$ & 875000 \\
\hline $\mathrm{RC}$ & 84086 & $17,20-21-4$ & 875000 \\
\hline $\mathrm{RC}$ & 84093 & $17,20-21-4$ & 875000 \\
\hline $\mathrm{RC}$ & 84100 & $17,20-21-4$ & 875000 \\
\hline $\mathrm{RC}$ & 84107 & $17,20-21-4$ & 875000 \\
\hline $\mathrm{RC}$ & 84114 & $17,20-21-4$ & 800000 \\
\hline $\mathrm{RC}$ & 84121 & $17,20-21-4$ & 875000 \\
\hline $\mathrm{RC}$ & 84128 & $17,20-21-4$ & 875000 \\
\hline
\end{tabular}

Table B-1. Continued.

\begin{tabular}{|c|c|c|c|c|}
\hline Type & Date & Sample\# & Reading & Units \\
\hline RC & 84135 & $17,20-21-4$ & 875000 & ohms \\
\hline RC & 84142 & $17,20-21-4$ & 875000 & ohms \\
\hline RC & 84151 & $17,20-21-4$ & 900000 & ohms \\
\hline $\mathrm{RC}$ & 84156 & $17,20-21-4$ & 875000 & ohms \\
\hline RC & 84163 & $17,20-21-4$ & 900000 & ohms \\
\hline RC & 84170 & $17,20-21-4$ & 1000000 & ohms \\
\hline RC & 84177 & $17,20-21-4$ & 900000 & ohms \\
\hline RC & 84184 & $17,20-21-4$ & 1250000 & ohms \\
\hline $\mathrm{RC}$ & 84191 & $17,20-21-4$ & 1150000 & ohms \\
\hline RC & 84198 & $17,20-21-4$ & 1150000 & ohms \\
\hline RC & 84205 & $17,20-21-4$ & 1150000 & ohms \\
\hline RC & 84212 & $17,20-21-4$ & 1150000 & ohms \\
\hline RC & 84219 & $17,20-21-4$ & 1000000 & ohms \\
\hline RC & 84226 & $17,20-21-4$ & 1150000 & ohms \\
\hline RC & 83192 & $30,31-21-10$ & 160000 & ohms \\
\hline RC & 83200 & $30,31-21-10$ & 155000 & ohms \\
\hline $\mathrm{RC}$ & 83206 & $30,31-21-10$ & 140000 & ohms \\
\hline $\mathrm{RC}$ & 83213 & $30,31-21-10$ & 135000 & ohms \\
\hline $\mathrm{RC}$ & 83220 & $30,31-21-10$ & 135000 & ohms \\
\hline RC & 83227 & $30,31-21-10$ & 120000 & ohms \\
\hline RC & 83241 & $30,31-21-10$ & 115000 & ohms \\
\hline RC & 83250 & $30,31-21-10$ & 110000 & ohms \\
\hline RC & 83255 & $30,31-21-10$ & 110000 & ohms \\
\hline RC & 83262 & $30,31-21-10$ & 102500 & ohms \\
\hline RC & 83271 & $30,31-21-10$ & 100000 & ohms \\
\hline $\mathrm{RC}$ & 83283 & $30,31-21-10$ & 97500 & ohms \\
\hline $\mathrm{RC}$ & 83297 & $30,31-21-10$ & 92500 & ohms \\
\hline RC & 83305 & $30,31-21-10$ & 90000 & ohms \\
\hline RC & 83311 & $30,31-21-10$ & 90000 & ohms \\
\hline RC & 83318 & $30,31-21-10$ & 90000 & ohms \\
\hline RC & 83325 & $30,31-21-10$ & 90000 & ohms \\
\hline RC & 83332 & $30,31-21-10$ & 87500 & ohms \\
\hline RC & 83339 & $30,31-21-10$ & 87500 & ohms \\
\hline RC & 83346 & $30,31-21-10$ & 90000 & ohms \\
\hline RC & 83353 & $30,31-21-10$ & 90000 & ohms \\
\hline $\mathrm{RC}$ & 83361 & $30,31-21-10$ & 89500 & ohms \\
\hline RC & 84003 & $30,31-21-10$ & 89500 & ohms \\
\hline RC & 84009 & $30,31-21-10$ & 90000 & ohms \\
\hline RC & 84016 & $30,31-21-10$ & 90000 & ohms \\
\hline RC & 84030 & $30,31-21-10$ & 92500 & ohms \\
\hline RC & 84037 & $30,31-21-10$ & 90000 & ohms \\
\hline RC & 84044 & $30,31-21-10$ & 90000 & ohms \\
\hline RC & 84052 & $30,31-21-10$ & 95000 & ohms \\
\hline RC & 84058 & $30,31-21-10$ & 95000 & ohms \\
\hline $\mathrm{RC}$ & 84065 & $30,31-21-10$ & 95000 & ohms \\
\hline RC & 84072 & $30,31-21-10$ & 87500 & ohms \\
\hline $\mathbf{R C}$ & 84079 & $30,31-21-10$ & 90000 & ohms \\
\hline RC & 84086 & $30,31-21-10$ & 90000 & ohms \\
\hline RC & 84093 & $30,31-21-10$ & 90000 & ohms \\
\hline RC & 84100 & $30,31-21-10$ & 92500 & ohms \\
\hline RC & 84107 & $30,31-21-10$ & 90000 & ohms \\
\hline RC & 84114 & $30,31-21-10$ & 90000 & ohms \\
\hline RC & 84121 & $30,31-21-10$ & 89000 & ohms \\
\hline RC & 84128 & $30,31-21-10$ & 86500 & ohms \\
\hline RC & 84135 & $30,31-21-10$ & 85000 & ohms \\
\hline RC & 84142 & $30,31-21-10$ & 84000 & ohms \\
\hline RC & 84151 & $30,31-21-10$ & 84000 & ohms \\
\hline RC & 84156 & $30,31-21-10$ & 83500 & ohms \\
\hline RC & 84163 & $30,31-21-10$ & 80000 & ohms \\
\hline RC & 84170 & $30,31-21-10$ & 82500 & ohms \\
\hline RC & 84177 & $30,31-21-10$ & 79000 & ohms \\
\hline RC & 84184 & $30,31-21-10$ & 80000 & ohms \\
\hline
\end{tabular}


Table B-1. Continued.

\begin{tabular}{|c|c|c|c|}
\hline Type & Date & Sample\# & Reading \\
\hline $\mathbf{R C}$ & 84191 & $30,31-21-10$ & 74000 \\
\hline $\mathbf{R C}$ & 84198 & $30,31-21-10$ & 75000 \\
\hline RC & 84205 & 30,31-21-10 & 74000 \\
\hline RC & 84212 & $30,31-21-10$ & 70000 \\
\hline $\mathrm{RC}$ & 84219 & $30,31-21-10$ & 68500 \\
\hline RC & 84226 & $30,31-21-10$ & 66500 \\
\hline $\mathrm{RC}$ & 83192 & $1,2-11-15$ & 660 \\
\hline $\mathrm{RC}$ & 83200 & $1,2-11-15$ & 1010 \\
\hline RC & 83206 & $1,2-11-15$ & 1250 \\
\hline $\mathrm{RC}$ & 83213 & $1,2-11-15$ & 1450 \\
\hline $\mathrm{RC}$ & 83220 & $1,2-11-15$ & 1550 \\
\hline RC & 83227 & $1,2-11-15$ & 1700 \\
\hline RC & 83241 & 1,2-11-15 & 1725 \\
\hline $\mathbf{R C}$ & 83250 & $1,2-11-15$ & 1740 \\
\hline $\mathrm{RC}$ & 83255 & $1,2-11-15$ & 1790 \\
\hline $\mathrm{RC}$ & 83262 & $1,2-11-15$ & 1800 \\
\hline RC & 83271 & $1,2-11-15$ & 1800 \\
\hline RC & 83283 & $1,2-11-15$ & 1900 \\
\hline $\mathrm{RC}$ & 83297 & $1,2-11-15$ & 1900 \\
\hline $\mathrm{RC}$ & 83305 & $1,2-11-15$ & 1950 \\
\hline $\mathrm{RC}$ & 83311 & $1,2-11-15$ & 1850 \\
\hline $\mathrm{RC}$ & 83318 & $1,2-11-15$ & 1900 \\
\hline $\mathbf{R C}$ & 83325 & $1,2-11-15$ & 1400 \\
\hline RC & 83332 & $1,2-11-15$ & 1850 \\
\hline $\mathrm{RC}$ & 83339 & $1,2-11-15$ & 1900 \\
\hline RC & 83346 & $1,2-11-15$ & 1950 \\
\hline $\mathrm{RC}$ & 83353 & $1,2-11-15$ & 1950 \\
\hline $\mathrm{RC}$ & 83361 & $1,2-11-15$ & 1875 \\
\hline $\mathbf{R C}$ & 84003 & $1,2-11-15$ & 1875 \\
\hline $\mathrm{RC}$ & 84009 & $1,2-11-15$ & 1925 \\
\hline $\mathbf{R C}$ & 84016 & $1,2-11-15$ & 1925 \\
\hline RC & 84030 & $1,2-11-15$ & 2100 \\
\hline $\mathbf{R C}$ & 84037 & $1,2-11-15$ & 2050 \\
\hline RC & 84044 & $1,2-11-15$ & 2013 \\
\hline $\mathrm{RC}$ & 84052 & $1,2-11-15$ & 2200 \\
\hline RC & 84058 & $1,2-11-15$ & 2200 \\
\hline RC & 84065 & $1,2-11-15$ & 2400 \\
\hline $\mathbf{R C}$ & 84072 & $1,2-11-15$ & 2350 \\
\hline RC & 84079 & $1,2-11-15$ & 2300 \\
\hline RC & 84086 & $1,2-11-15$ & 2300 \\
\hline RC & 84093 & $1,2-11-15$ & 2300 \\
\hline $\mathrm{RC}$ & 84100 & $1,2-11-15$ & 2350 \\
\hline $\mathbf{R C}$ & 84107 & $1,2-11-15$ & 2450 \\
\hline $\mathrm{RC}$ & 84114 & $1,2-11-15$ & 2450 \\
\hline $\mathbf{R C}$ & 84121 & $1,2-11-15$ & 2450 \\
\hline RC & 84128 & $1,2-11-15$ & 2350 \\
\hline RC & 84135 & $1,2-11-15$ & 2450 \\
\hline$R C$ & 84142 & $1,2-11-15$ & 2450 \\
\hline $\mathbf{R C}$ & 84151 & $1,2-11-15$ & 2450 \\
\hline $\mathbf{R C}$ & 84156 & $1,2-11-15$ & 2450 \\
\hline RC & 84163 & $1,2-11-15$ & 2450 \\
\hline RC & 84170 & $1,2-11-15$ & 2350 \\
\hline RC & 84177 & $1,2-11-15$ & 2450 \\
\hline $\mathbf{R C}$ & 84184 & $1,2-11-15$ & 2400 \\
\hline RC & 84191 & $1,2-11-15$ & 2450 \\
\hline RC & 84198 & $1,2-11-15$ & 2550 \\
\hline $\mathrm{RC}$ & 84205 & $1,2-11-15$ & 3000 \\
\hline RC & 84212 & $1,2-11-15$ & 2450 \\
\hline RC & 84219 & $1,2-11-15$ & 2450 \\
\hline RC & 84226 & $1,2-11-15$ & 2450 \\
\hline RC & 83192 & $7,8-11-10$ & 9000 \\
\hline $\mathrm{RC}$ & 83200 & $7,8-11-10$ & 8000 \\
\hline
\end{tabular}

Table B-1. Continued.

\begin{tabular}{|c|c|c|c|c|}
\hline Type & Date & Sample\# & Reading & Units \\
\hline RC & 83206 & $7,8-11-10$ & 7500 & ohms \\
\hline $\mathrm{RC}$ & 83213 & $7,8-11-10$ & 7000 & ohms \\
\hline RC & 83220 & $7,8-11-10$ & 6050 & ohms \\
\hline RC & 83227 & $7,8-11-10$ & 5900 & ohms \\
\hline $\mathrm{RC}$ & 83241 & $7,8-11-10$ & 5250 & ohms \\
\hline $\mathrm{RC}$ & 83250 & $7,8-11-10$ & 5100 & ohms \\
\hline RC & 83255 & $7,8-11-10$ & 5000 & ohms \\
\hline RC & 83262 & $7,8-11-10$ & 6000 & ohms \\
\hline RC & 83271 & $7,8-11-10$ & 5000 & ohms \\
\hline $\mathrm{RC}$ & 83283 & $7,8-11-10$ & 4650 & ohms \\
\hline $\mathrm{RC}$ & 83297 & $7,8-11-10$ & 4650 & ohms \\
\hline $\mathrm{RC}$ & 83305 & $7,8-11-10$ & 4650 & ohms \\
\hline RC & 83311 & $7,8-11-10$ & 4650 & ohms \\
\hline RC & 83318 & $7,8-11-10$ & 4650 & ohms \\
\hline RC & 83325 & $7,8-11-10$ & 4450 & ohms \\
\hline RC & 83332 & $7,8-11-10$ & 4300 & ohms \\
\hline RC & 83339 & $7,8-11-10$ & 4300 & ohms \\
\hline RC & 83346 & $7,8-11-10$ & 4400 & ohms \\
\hline $\mathrm{RC}$ & 83353 & $7,8-11-10$ & 4300 & ohms \\
\hline $\mathrm{RC}$ & 83361 & $7,8-11-10$ & 4450 & ohms \\
\hline RC & 84003 & $7,8-11-10$ & 4450 & ohms \\
\hline RC & 84009 & $7,8-11-10$ & 4500 & ohms \\
\hline RC & 84016 & $7,8-11-10$ & 4500 & ohms \\
\hline $\mathrm{RC}$ & 84030 & $7,8-11-10$ & 4550 & ohms \\
\hline RC & 84037 & $7,8-11-10$ & 4550 & ohms \\
\hline $\mathrm{RC}$ & 84044 & $7,8-11-10$ & 4925 & ohms \\
\hline RC & 84052 & $7,8-11-10$ & 4800 & ohms \\
\hline RC & 84058 & $7,8-11-10$ & 4850 & ohms \\
\hline RC & 84065 & $7,8-11-10$ & 4900 & ohms \\
\hline RC & 84072 & $7,8-11-10$ & 4850 & ohms \\
\hline RC & 84079 & $7,8-11-10$ & 4900 & ohms \\
\hline $\mathrm{RC}$ & 84086 & $7,8-11-10$ & 4850 & ohms \\
\hline RC & 84093 & $7,8-11-10$ & 4700 & ohms \\
\hline RC & 84100 & $7,8-11-10$ & 5150 & ohms \\
\hline RC & 84107 & $7,8-11-10$ & 4900 & ohms \\
\hline RC & 84114 & $7,8-11-10$ & 5100 & ohms \\
\hline RC & 84121 & $7,8-11-10$ & 5300 & ohms \\
\hline $\mathrm{RC}$ & 84128 & $7,8-11-10$ & 5000 & ohms \\
\hline $\mathrm{RC}$ & 84135 & $7,8-11-10$ & 4800 & ohms \\
\hline $\mathrm{RC}$ & 84142 & $7,8-11-10$ & 4900 & ohms \\
\hline RC & 84151 & $7,8-11-10$ & 4800 & ohms \\
\hline RC & 84156 & $7,8-11-10$ & 4650 & ohms \\
\hline $\mathrm{RC}$ & 84163 & $7,8-11-10$ & 4650 & ohms \\
\hline $\mathrm{RC}$ & 84170 & $7,8-11-10$ & 4550 & ohms \\
\hline RC & 84177 & $7,8-11-10$ & 4550 & ohms \\
\hline $\mathrm{RC}$ & 84184 & $7,8-11-10$ & 4500 & ohms \\
\hline RC & 84191 & $7,8-11-10$ & 4750 & ohms \\
\hline RC & 84198 & $7,8-11-10$ & 4400 & ohms \\
\hline $\mathrm{RC}$ & 84205 & $7,8-11-10$ & 4400 & ohms \\
\hline $\mathrm{RC}$ & 84212 & $7,8-11-10$ & 4250 & ohms \\
\hline RC & 84219 & $7,8-11-10$ & 4250 & ohms \\
\hline $\mathrm{RC}$ & 84226 & $7,8-11-10$ & 4050 & ohms \\
\hline $\mathrm{RC}$ & 83192 & $10,11-11-5$ & 230000 & ohms \\
\hline $\mathrm{RC}$ & 83200 & $10,11-11-5$ & 235000 & ohms \\
\hline RC & 83206 & $10,11-11-5$ & 250000 & ohms \\
\hline RC & 83213 & $10,11-11-5$ & 235000 & ohms \\
\hline $\mathrm{RC}$ & 83220 & $10,11-11-5$ & 18500 & ohms \\
\hline RC & 83227 & $10,11-11-5$ & 17000 & ohms \\
\hline $\mathrm{RC}$ & 83241 & $10,11-11-5$ & 145000 & ohms \\
\hline RC & 83250 & $10,11-11-5$ & 140000 & ohms \\
\hline RC & 83255 & $10,11-11-5$ & 130000 & ohms \\
\hline RC & 83262 & $10,11-11-5$ & 120000 & ohms \\
\hline
\end{tabular}


Table B-1. Continued.

\begin{tabular}{|c|c|c|c|c|c|c|c|c|c|}
\hline Type & Date & Sample\# & Reading & Units & Type & Date & Sample\# & Reading & Units \\
\hline $\mathrm{RC}$ & 83271 & $10,11-11-5$ & 115000 & ohms & NP & 83339 & 11-5 & 13.1 & $\% \mathrm{VM}$ \\
\hline RC & 83283 & $10,11-11-5$ & 110000 & ohms & NP & 83346 & $11-5$ & 13.2 & $\% \mathrm{VM}$ \\
\hline $\mathrm{RC}$ & 83297 & $10,11-11-5$ & 105000 & ohms & NP & 83353 & $11-5$ & 12.7 & $\% \mathrm{VM}$ \\
\hline $\mathrm{RC}$ & 83305 & $10,11-11-5$ & 100000 & ohms & NP & 83361 & $11-5$ & 13.0 & $\% \mathrm{VM}$ \\
\hline $\mathrm{RC}$ & 83311 & $10,11-11-5$ & 100000 & ohms & $\mathrm{NP}$ & 84003 & $11-5$ & 12.5 & $\% \mathbf{V M}$ \\
\hline $\mathrm{RC}$ & 83318 & $10,11-11-5$ & 100000 & ohms & NP & 84009 & $11-5$ & 13.2 & $\% \mathrm{VM}$ \\
\hline $\mathrm{RC}$ & 83325 & $10,11-11-5$ & 100000 & ohms & NP & 84016 & $11-5$ & 13.5 & $\% \mathrm{VM}$ \\
\hline $\mathrm{RC}$ & 83332 & $10,11-11-5$ & 100000 & ohms & NP & 84030 & $11-5$ & $* * * *$ & $\% \mathrm{VM}$ \\
\hline $\mathrm{RC}$ & 83339 & $10,11-11-5$ & 100000 & ohms & NP & 84037 & $11-5$ & $* * * *$ & $\% \mathrm{VM}$ \\
\hline $\mathrm{RC}$ & 83346 & $10,11-11-5$ & 100000 & ohms & NP. & 84044 & $11-5$ & $* * * *$ & $\% \mathrm{VM}$ \\
\hline $\mathrm{RC}$ & 83353 & $10,11-11-5$ & 97500 & ohms & $N P^{\prime}$ & 84052 & $11-5$ & $* * * *$ & $\% \mathrm{VM}$ \\
\hline $\mathrm{RC}$ & 83361 & $10,11-11-5$ & 100000 & ohms & NP & 84058 & $11-5$ & $* * * *$ & $\% \mathrm{VM}$ \\
\hline $\mathrm{RC}$ & 84003 & $10,11-11-5$ & 99500 & ohms & NP & 84065 & $11-5$ & $* * * *$ & $\% \mathbf{V M}$ \\
\hline RC & 84009 & $10,11-11-5$ & 105000 & ohms & NP & 84072 & $11-5$ & $* * * *$ & $\% \mathrm{VM}$ \\
\hline $\mathrm{RC}$ & 84016 & $10,11-11-5$ & 97500 & ohms & NP & 84079 & $11-5$ & $* * * *$ & $\% \mathrm{VM}$ \\
\hline $\mathrm{RC}$ & 84030 & $10,11-11-5$ & 104500 & ohms & NP & 84086 & $11-5$ & $* * * *$ & $\% \mathbf{V M}$ \\
\hline $\mathrm{RC}$ & 84037 & $10,11-11-5$ & 101500 & ohms & $\mathrm{NP}$ & 84093 & $11-5$ & $* * * *$ & $\% \mathbf{V M}$ \\
\hline RC & 84044 & $10,11-11-5$ & 100000 & ohms & $\mathrm{NP}$ & 84100 & $11-5$ & 12.8 & $\% \mathbf{V M}$ \\
\hline RC & 84052 & $10,11-11-5$ & 100000 & ohms & NP & 84107 & $11-5$ & 12.1 & $\% \mathrm{VM}$ \\
\hline $\mathrm{RC}$ & 84058 & $10,11-11-5$ & 100000 & ohms & NP & 84114 & $11-5$ & 12.3 & $\% \mathrm{VM}$ \\
\hline $\mathrm{RC}$ & 84065 & $10,11-11-5$ & 100000 & ohms & NP & 84121 & $11-5$ & 13.3 & $\% \mathbf{V M}$ \\
\hline $\mathrm{RC}$ & 84072 & $10,11-11-5$ & 89000 & ohms & $\mathrm{NP}$ & 84128 & $11-5$ & 12.8 & $\% \mathrm{VM}$ \\
\hline $\mathrm{RC}$ & 84079 & $10,11-11-5$ & 89000 & ohms & NP & 84135 & $11-5$ & 13.2 & $\% \mathbf{V M}$ \\
\hline $\mathrm{RC}$ & 84086 & $10,11-11-5$ & 88500 & ohms & NP & 84142 & $11-5$ & 13.5 & $\% \mathbf{V M}$ \\
\hline RC & 84093 & $10,11-11-5$ & 83500 & ohms & $\mathrm{NP}$ & 84151 & $11-5$ & $* * * *$ & $\% \mathbf{V M}$ \\
\hline $\mathrm{RC}$ & 84100 & $10,11-11-5$ & 83000 & ohms & NP & 84156 & $11-5$ & $* * * *$ & $\% \mathrm{VM}$ \\
\hline RC & 84107 & $10,11-11-5$ & 78000 & ohms & NP & 84163 & $11-5$ & $* * * *$ & $\% \mathrm{VM}$ \\
\hline $\mathrm{RC}$ & 84114 & $10,11-11-5$ & 75000 & ohms & $\mathrm{NP}$ & 84170 & $11-5$ & $* * * *$ & $\% \mathrm{VM}$ \\
\hline RC & 84121 & $10,11-11-5$ & 73500 & ohms & NP & 84177 & $11-5$ & $* * * *$ & $\%$ VM \\
\hline $\mathrm{RC}$ & 84128 & $10,11-11-5$ & 68500 & ohms & $\mathrm{NP}$ & 84184 & $11-5$ & $* * * *$ & $\% \mathrm{VM}$ \\
\hline RC & 84135 & $10,11-11-5$ & 66000 & ohms & NP & 84191 & $11-5$ & $* * * *$ & $\% \mathrm{VM}$ \\
\hline RC & 84142 & $10,11-11-5$ & 62500 & ohms & NP & 84198 & $11-5$ & 13.6 & $\% \mathrm{VM}$ \\
\hline RC & 84151 & $10,11-11-5$ & 58000 & ohms & NP & 84205 & $11-5$ & 13.8 & $\% \mathrm{VM}$ \\
\hline RC & 84156 & $10,11-11-5$ & 56500 & ohms & $\mathrm{NP}$ & 84212 & $11-5$ & $* * * *$ & $\% \mathrm{VM}$ \\
\hline RC & 84163 & $10,11-11-5$ & 54500 & ohms & $\mathrm{NP}$ & 84219 & $11-5$ & 12.9 & $\% \mathrm{VM}$ \\
\hline RC & 84170 & $10,11-11-5$ & 51000 & ohms & $\mathrm{NP}$ & 84226 & $11-5$ & 13.0 & $\% \mathrm{VM}$ \\
\hline $\mathbf{R C}$ & 84177 & $10,11-11-5$ & 47500 & ohms & $\mathrm{NP}$ & 83192 & $11-7.5$ & 15.2 & $\% \mathrm{VM}$ \\
\hline $\mathrm{RC}$ & 84184 & $10,11-11-5$ & 45000 & ohms & NP & 83200 & $11-7.5$ & 15.5 & $\% \mathrm{VM}$ \\
\hline RC & 84191 & $10,11-11-5$ & 42500 & ohms & NP & 83206 & $11-7.5$ & 15.1 & $\% \mathrm{VM}$ \\
\hline RC & 84198 & $10,11-11-5$ & 37500 & ohms & NP & 83213 & $11-7.5$ & 14.7 & $\% \mathrm{VM}$ \\
\hline $\mathrm{RC}$ & 84205 & $10,11-11-5$ & 37500 & ohms & NP & 83220 & $11-7.5$ & 15.5 & $\% \mathrm{VM}$ \\
\hline $\mathbf{R C}$ & 84212 & $10,11-11-5$ & 36000 & ohms & NP & 83227 & $11-7.5$ & 14.7 & $\% \mathrm{VM}$ \\
\hline $\mathbf{R C}$ & 84219 & $10,11-11-5$ & 36000 & ohms & NP & 83241 & $11-7.5$ & 14.8 & $\% \mathrm{VM}$ \\
\hline $\mathrm{RC}$ & 84226 & $10,11-11-5$ & 33000 & ohms & NP & 83250 & $11-7.5$ & 14.9 & $\% \mathrm{VM}$ \\
\hline NP & 83192 & $11-5$ & 12.00 & $\% \mathrm{VM}$ & NP & 83255 & $11-7.5$ & 15.3 & $\% \mathrm{VM}$ \\
\hline NP & 83200 & $11-5$ & 12.7 & $\% \mathrm{VM}$ & NP & 83262 & $11-7.5$ & 13.0 & $\% \mathrm{VM}$ \\
\hline NP & 83206 & $11-5$ & 12.7 & $\%$ VM & NP & 83271 & $11-7.5$ & 14.9 & $\% \mathrm{VM}$ \\
\hline NP & 83213 & $11-5$ & 12.3 & $\% \mathbf{V M}$ & NP & 83283 & $11-7.5$ & 14.3 & $\% \mathrm{VM}$ \\
\hline NP & 83220 & $11-5$ & 13.0 & $\% \mathbf{V M}$ & NP & 83297 & $11-7.5$ & 14.4 & $\% \mathrm{VM}$ \\
\hline NP & 83227 & $11-5$ & 12.5 & $\% \mathbf{V M}$ & NP & 83305 & $11-7.5$ & 14.6 & $\% \mathrm{VM}$ \\
\hline NP & 83241 & $11-5$ & 13.3 & $\% \mathrm{VM}$ & NP & 83311 & $11-7.5$ & 14.3 & $\% \mathrm{VM}$ \\
\hline NP & 83250 & $11-5$ & 13.0 & $\% \mathbf{V M}$ & NP & 83318 & $11-7.5$ & 14.4 & $\% \mathrm{VM}$ \\
\hline NP & 83255 & $11-5$ & 13.1 & $\% \mathrm{VM}$ & NP & 83325 & $11-7.5$ & 14.5 & $\% \mathrm{VM}$ \\
\hline NP & 83262 & $11-5$ & 15.2 & $\% \mathrm{VM}$ & NP & 83332 & $11-7.5$ & 14.6 & $\% \mathbf{V M}$ \\
\hline NP & 83271 & $11-5$ & 13.0 & $\% \mathrm{VM}$ & NP & 83339 & $11-7.5$ & 14.3 & $\% \mathrm{VM}$ \\
\hline NP & 83283 & $11-5$ & 13.7 & $\% \mathrm{VM}$ & NP & 83346 & $11-7.5$ & 15.0 & $\% \mathrm{VM}$ \\
\hline NP & 83297 & $11-5$ & 13.0 & $\% \mathrm{VM}$ & NP & 83353 & $11-7.5$ & 14.2 & $\% \mathbf{V M}$ \\
\hline NP & 83305 & $11-5$ & 14.0 & $\% \mathrm{VM}$ & NP & 83361 & $11-7.5$ & 14.2 & $\% \mathrm{VM}$ \\
\hline NP & 83311 & $11-5$ & 12.9 & $\% \mathrm{VM}$ & NP & 84003 & $11-7.5$ & 14.6 & $\% \mathbf{V M}$ \\
\hline NP & 83318 & $11-5$ & 13.6 & $\% \mathrm{VM}$ & NP & 84009 & $11-7.5$ & 14.8 & $\% \mathrm{VM}$ \\
\hline NP & 83325 & $11-5$ & 13.1 & $\% \mathrm{VM}$ & NP & 84016 & $11-7.5$ & 14.8 & $\% \mathrm{VM}$ \\
\hline NP & 83332 & $11-5$ & 13.1 & $\% \mathrm{VM}$ & NP & 84030 & $11-7.5$ & $* * * *$ & $\% \mathrm{VM}$ \\
\hline
\end{tabular}

Table B-1. Continued. 
Table B-1. Continued.

\begin{tabular}{|c|c|c|c|c|c|c|c|c|c|}
\hline Type & Date & Sample\# & Reading & Units & Type & Date & Sample\# & Reading & Units \\
\hline NP & 84037 & $11-7.5$ & $* * * *$ & $\% \mathbf{V M}$ & NP & 84093 & $11-10$ & $* * * *$ & $\% \mathbf{V M}$ \\
\hline NP & 84044 & $11-7.5$ & $* * * *$ & $\% \mathbf{V M}$ & NP & 84100 & $11-10$ & 14.5 & $\% \mathbf{V M}$ \\
\hline NP & 84052 & $11-7.5$ & $* * * *$ & $\% \mathrm{VM}$ & NP & 84107 & $11-10$ & 13.7 & $\% \mathrm{VM}$ \\
\hline NP & 84058 & $11-7.5$ & $* * * *$ & $\% \mathrm{VM}$ & $\mathrm{NP}$ & 84114 & $11-10$ & 13.9 & $\% \mathbf{V M}$ \\
\hline NP & 84065 & $11-7.5$ & $* * * *$ & $\% \mathbf{V M}$ & NP & 84121 & $11-10$ & 13.4 & $\% \mathbf{V M}$ \\
\hline NP & 84072 & $11-7.5$ & $* * * *$ & $\% \mathbf{V M}$ & $\mathrm{NP}$ & 84128 & $11-10$ & 14.0 & $\% \mathbf{V M}$ \\
\hline NP & 84079 & $11-7.5$ & $* * * *$ & $\% \mathrm{VM}$ & $\mathrm{NP}$ & 84135 & $11-10$ & 13.6 & $\% \mathrm{VM}$ \\
\hline NP & 84086 & $11-7.5$ & $* * * *$ & $\% \mathbf{V M}$ & NP & 84142 & $11-10$ & 13.3 & $\% \mathbf{V M}$ \\
\hline NP & 84093 & $11-7.5$ & $* * * *$ & $\% \mathrm{VM}$ & NP & 84151 & $11-10$ & $* * * *$ & $\% \mathrm{VM}$ \\
\hline NP & 84100 & $11-7.5$ & 15.5 & $\% \mathbf{V M}$ & NP & 84156 & $11-10$ & $* * * *$ & $\% \mathbf{V M}$ \\
\hline NP & 84107 & $11-7.5$ & 14.8 & $\% \mathrm{VM}$ & NP & 84163 & $11-10$ & $* * * *$ & $\% \mathbf{V M}$ \\
\hline NP & 84114 & $11-7.5$ & 14.6 & $\% \mathrm{VM}$ & NP & 84170 & $11-10$ & $* * * *$ & $\% \mathrm{VM}$ \\
\hline NP & 84121 & $11-7.5$ & 15.3 & $\% \mathrm{VM}$ & NP & 84177 & $11-10$ & $* * * *$ & $\% \mathbf{V M}$ \\
\hline NP & 84128 & $11-7.5$ & 15.7 & $\% \mathrm{VM}$ & NP & 84184 & $11-10$ & $* * * *$ & $\% \mathrm{VM}$ \\
\hline NP & 84135 & $11-7.5$ & 14.4 & $\% \mathrm{VM}$ & NP & 84191 & $11-10$ & $* * * *$ & $\% \mathrm{VM}$ \\
\hline NP & 84142 & $11-7.5$ & 15.3 & $\% \mathrm{VM}$ & $\mathrm{NP}$ & 84198 & $11-10$ & 13.2 & $\% \mathrm{VM}$ \\
\hline NP & 84151 & $11-7.5$ & $* * * *$ & $\% \mathrm{VM}$ & $\mathrm{NP}$ & 84205 & $11-10$ & 14.4 & $\% \mathrm{VM}$ \\
\hline NP & 84156 & $11-7.5$ & $* * * *$ & $\% \mathrm{VM}$ & $\mathrm{NP}$ & 84212 & $11-10$ & $* * * *$ & $\% \mathrm{VM}$ \\
\hline NP & 84163 & $11-7.5$ & $* * * *$ & $\% \mathbf{V M}$ & NP & 84219 & $11-10$ & 13.1 & $\% \mathbf{V M}$ \\
\hline NP & 84170 & $11-7.5$ & $* * * *$ & $\% \mathrm{VM}$ & NP & 84226 & $11-10$ & 11.1 & $\% \mathbf{V M}$ \\
\hline NP & 84177 & $11-7.5$ & $* * * *$ & $\% \mathbf{V M}$ & $\mathrm{NP}$ & 83192 & $11-12.5$ & 14.6 & $\% \mathbf{V M}$ \\
\hline NP & 84184 & $11-7.5$ & $* * * *$ & $\% \mathrm{VM}$ & NP & 83200 & $11-12.5$ & 14.7 & $\% \mathrm{VM}$ \\
\hline NP & 84191 & $11-7.5$ & $* * * *$ & $\% \mathbf{V M}$ & $\mathrm{NP}$ & 83206 & $11-12.5$ & 15.5 & $\% \mathrm{VM}$ \\
\hline NP & 84198 & $11-7.5$ & 15.1 & $\% \mathbf{V M}$ & NP & 83213 & $11-12.5$ & 14.5 & $\% \mathrm{VM}$ \\
\hline NP & 84205 & $11-7.5$ & 14.7 & $\% \mathbf{V M}$ & NP & 83220 & $11-12.5$ & 15.0 & $\% \mathrm{VM}$ \\
\hline NP & 84212 & $.11-7.5$ & $* * * *$ & $\% \mathbf{V M}$ & $\mathrm{NP}$ & 83227 & $11-12.5$ & 14.8 & $\% \mathbf{V M}$ \\
\hline NP & 84219 & $11-7.5$ & 16.3 & $\% \mathbf{V M}$ & NP & 83241 & $11-12.5$ & 14.5 & $\% \mathbf{V M}$ \\
\hline NP & 84226 & $11-7.5$ & 13.3 & $\% \mathbf{V M}$ & $\mathrm{NP}$ & 83250 & $11-12.5$ & 15.1 & $\% \mathbf{V M}$ \\
\hline NP & 83192 & $11-10$ & 14.8 & $\% \mathbf{V M}$ & NP & 83255 & $11-12.5$ & 14.4 & $\% \mathrm{VM}$ \\
\hline $\mathrm{NP}$ & 83200 & $11-10$ & 15.0 & $\% \mathbf{V M}$ & NP & 83262 & $11-12.5$ & 14.0 & $\% \mathbf{V M}$ \\
\hline NP & 83206 & $11-10$ & 14.8 & $\% \mathbf{V M}$ & NP & 83271 & $11-12.5$ & 14.8 & $\% \mathbf{V M}$ \\
\hline NP & 83213 & $11-10$ & 14.6 & $\% \mathbf{V M}$ & NP & 83283 & $11-12.5$ & 14.2 & $\% \mathbf{V M}$ \\
\hline NP & 83220 & $11-10$ & 15.3 & $\% \mathbf{V M}$ & NP & 83297 & $11-12.5$ & 15.4 & $\% \mathbf{V M}$ \\
\hline NP & 83227 & $11-10$ & 14.5 & $\% \mathrm{VM}$ & NP & 83305 & $11-12.5$ & 14.3 & $\% \mathrm{VM}$ \\
\hline NP & 83241 & $11-10$ & 14.7 & $\% \mathrm{VM}$ & NP & 83311 & $11-12.5$ & 14.2 & $\% \mathbf{V M}$ \\
\hline NP & 83250 & $11-10$ & 14.7 & $\% \mathrm{VM}$ & NP & 83318 & $11-12.5$ & 15.6 & $\% \mathbf{V M}$ \\
\hline NP & 83255 & $11-10$ & 13.3 & $\% \mathbf{V M}$ & NP & 83325 & $11-12.5$ & 14.5 & $\% \mathbf{V M}$ \\
\hline NP & 83262 & $11-10$ & 15.1 & $\% \mathrm{VM}$ & NP & 83332 & $11-12.5$ & 14.3 & $\% \mathrm{VM}$ \\
\hline NP & 83271 & $11-10$ & 13.7 & $\% \mathrm{VM}$ & NP & 83339 & $11-12.5$ & 14.6 & $\% \mathrm{VM}$ \\
\hline NP & 83283 & $11-10$ & 14.6 & $\% \mathrm{VM}$ & NP & 83346 & $11-12.5$ & 15.0 & $\% \mathbf{V M}$ \\
\hline NP & 83297 & $11-10$ & 14.2 & $\% \mathrm{VM}$ & NP & 83353 & $11-12.5$ & 14.6 & $\% \mathrm{VM}$ \\
\hline NP & 83305 & $11-10$ & 13.3 & $\% \mathrm{VM}$ & NP & 83361 & $11-12.5$ & 14.6 & $\% \mathbf{V M}$ \\
\hline NP & 83311 & $11-10$ & 13.7 & $\% \mathrm{VM}$ & NP & 84003 & $11-12.5$ & 15.8 & $\% \mathrm{VM}$ \\
\hline NP & 83318 & $11-10$ & 14.8 & $\% \mathrm{VM}$ & NP & 84009 & $11-12.5$ & 14.5 & $\% \mathrm{VM}$ \\
\hline $\mathbf{N P}$ & 83325 & $11-10$ & 13.2 & $\% \mathrm{VM}$ & NP & 84016 & $11-12.5$ & 15.0 & $\% \mathrm{VM}$ \\
\hline NP & 83332 & $11-10$ & 14.4 & $\% \mathbf{V M}$ & NP & 84030 & $11-12.5$ & $* * * *$ & $\% \mathrm{VM}$ \\
\hline NP & 83339 & $11-10$ & 15.3 & $\% \mathbf{V M}$ & NP & 84037 & $11-12.5$ & $* * * *$ & $\% \mathrm{VM}$ \\
\hline NP & 83346 & $11-10$ & 14.8 & $\% \mathbf{V M}$ & NP & 84044 & $11-12.5$ & $* * * *$ & $\% \mathrm{VM}$ \\
\hline NP & 83353 & $11-10$ & 13.6 & $\% \mathbf{V M}$ & NP & 84052 & $11-12.5$ & $* * * *$ & $\% \mathrm{VM}$ \\
\hline NP & 83361 & $11-10$ & 14.2 & $\% \mathbf{V M}$ & NP & 84058 & $11-12.5$ & $* * * *$ & $\% \mathrm{VM}$ \\
\hline NP & 84003 & $11-10$ & 14.0 & $\% \mathrm{VM}$ & NP & 84065 & $11-12.5$ & $* * * *$ & $\% \mathrm{VM}$ \\
\hline NP & 84009 & $11-10$ & 14.1 & $\% \mathrm{VM}$ & NP & 84072 & $11-12.5$ & $* * * *$ & $\% \mathrm{VM}$ \\
\hline NP & 84016 & $11-10$ & 14.3 & $\% \mathrm{VM}$ & NP & 84079 & $11-12.5$ & $* * * *$ & $\% \mathrm{VM}$ \\
\hline NP & 84030 & $11-10$ & $* * * *$ & $\% \mathrm{VM}$ & NP & 84086 & $11-12.5$ & $* * * *$ & $\% \mathrm{VM}$ \\
\hline NP & 84037 & $11-10$ & $* * * *$ & $\% \mathrm{VM}$ & NP & 84093 & $11-12.5$ & $* * * *$ & $\% \mathbf{V M}$ \\
\hline NP & 84044 & $11-10$ & $* * * *$ & $\% \mathrm{VM}$ & NP & 84100 & $11-12.5$ & 14.9 & $\% \mathrm{VM}$ \\
\hline NP & 84052 & $11-10$ & $* * * *$ & $\% \mathrm{VM}$ & NP & 84107 & $11-12.5$ & 15.1 & $\% \mathrm{VM}$ \\
\hline NP & 84058 & $11-10$ & $* * * *$ & $\% \mathbf{V M}$ & NP & 84114 & $11-12.5$ & 13.9 & $\% \mathbf{V M}$ \\
\hline NP & 84065 & $11-10$ & $* * * *$ & $\% \mathbf{V M}$ & NP & 84121 & $11-12.5$ & 14.8 & $\% \mathrm{VM}$ \\
\hline NP & 84072 & $11-10$ & $* * * *$ & $\% \mathbf{V M}$ & NP & 84128 & $11-12.5$ & 15.1 & $\% \mathbf{V M}$ \\
\hline NP & 84079 & $11-10$ & $* * * *$ & $\% \mathrm{VM}$ & NP & 84135 & $11-12.5$ & 15.1 & $\% \mathbf{V M}$ \\
\hline NP & 84086 & $11-10$ & $* * * *$ & $\% \mathrm{VM}$ & NP & 84142 & $11-12.5$ & 13.8 & $\% \mathrm{VM}$ \\
\hline
\end{tabular}

Table B-1. Continued. 
Table B-1. Continued.

\begin{tabular}{|c|c|c|c|c|c|c|c|c|c|}
\hline Type & Date & Sample\# & Reading & Units & Type & Date & Sample\# & Reading & Units \\
\hline NP & 84151 & $11-12.5$ & $* * * *$ & $\% \mathrm{VM}$ & $\mathrm{NP}$ & 84205 & 11-15 & 13.3 & $\% \mathrm{VM}$ \\
\hline NP & 84156 & $11-12.5$ & $* * * *$ & $\% \mathrm{VM}$ & $\mathrm{NP}$ & 84212 & 11-15 & $* * * *$ & $\% \mathrm{VM}$ \\
\hline NP & 84163 & $11-12.5$ & $* * * *$ & $\% \mathrm{VM}$ & NP & 84219 & 11-15 & 12.5 & $\% \mathrm{VM}$ \\
\hline NP & 84170 & $11-12.5$ & $* * * *$ & $\% \mathrm{VM}$ & NP & 84226 & $11-15$ & 10.9 & $\% \mathrm{VM}$ \\
\hline NP & 84177 & $11-12.5$ & $* * * *$ & $\% \mathrm{VM}$ & $T$ & & & & \\
\hline NP & 84184 & $11-12.5$ & $* * * *$ & $\% \mathrm{VM}$ & $\mathrm{T}$ & 83192 & $1,6-0-3$ & 7 & cbar \\
\hline NP & 84191 & $11-12.5$ & $* * * *$ & $\% \mathrm{VM}$ & $\mathrm{T}$ & 83200 & $1,6-0-3$ & 8 & cbar \\
\hline NP & 84198 & $11-12.5$ & 14.7 & $\% \mathrm{VM}$ & $\mathrm{T}$ & 83206 & $1,6-0-3$ & 9 & cbar \\
\hline NP & 84205 & $11-12.5$ & 14.6 & $\% \mathrm{VM}$ & $\mathbf{T}$ & 83213 & $1,6-0-3$ & 8 & cbar \\
\hline NP & 84212 & $11-12.5$ & $* * * *$ & $\% \mathrm{VM}$ & $\mathrm{T}$ & 83220 & $1,6-0-3$ & 8 & cbar \\
\hline NP & 84219 & $11-12.5$ & 14.1 & $\% \mathrm{VM}$ & $\mathrm{T}$ & 83227 & $1,6-0-3$ & 8 & cbar \\
\hline NP & 84226 & $11-12.5$ & 12.5 & $\% \mathrm{VM}$ & $\mathrm{T}$ & 83241 & $1,6-0-3$ & 7 & cbar \\
\hline NP & 83192 & $11-15$ & 14.0 & $\% \mathrm{VM}$ & $\mathbf{T}$ & 83250 & $1,6-0-3$ & 8 & cbar \\
\hline NP & 83200 & $11-15$ & 14.2 & $\% \mathrm{VM}$ & $\mathbf{T}$ & 83255 & $1,6-0-3$ & 8 & cbar \\
\hline NP & 83206 & $11-15$ & 13.5 & $\% \mathrm{VM}$ & $\mathbf{T}$ & 83262 & $1,6-0-3$ & 8 & cbar \\
\hline NP & 83213 & $11-15$ & 13.0 & $\% \mathbf{V M}$ & $\mathbf{T}$ & 83271 & $1,6-0-3$ & 7 & cbar \\
\hline NP & 83220 & $11-15$ & 13.8 & $\% \mathbf{V M}$ & $\mathbf{T}$ & 83283 & $1,6-0-3$ & 7 & cbar \\
\hline NP & 83227 & $11-15$ & 13.3 & $\% \mathrm{VM}$ & $\mathbf{T}$ & 83297 & $1,6-0-3$ & 7 & cbar \\
\hline NP & 83241 & $11-15$ & 14.4 & $\% \mathrm{VM}$ & $\mathbf{T}$ & 83305 & $1,6-0-3$ & 8 & cbar \\
\hline NP & 83250 & $11-15$ & 14.7 & $\% \mathrm{VM}$ & $\mathbf{T}$ & 83311 & $1,6-0-3$ & 7 & cbar \\
\hline NP & 83255 & $11-15$ & 14.1 & $\% \mathrm{VM}$ & $\mathbf{T}$ & 83318 & $1,6-0-3$ & 7 & cbar \\
\hline NP & 83262 & $11-15$ & 13.9 & $\% \mathrm{VM}$ & $\mathbf{T}$ & 83325 & $1,6-0-3$ & 8 & cbar \\
\hline NP & 83271 & $11-15$ & 13.9 & $\% \mathrm{VM}$ & $\mathrm{T}$ & 83332 & $1,6-0-3$ & 0 & cbar \\
\hline NP & 83283 & $11-15$ & 14.5 & $\% \mathrm{VM}$ & $\mathrm{T}$ & 83339 & $1,6-0-3$ & * & cbar \\
\hline NP & 83297 & $11-15$ & 14.4 & $\% \mathrm{VM}$ & $\mathrm{T}$ & 83346 & $1,6-0-3$ & $*$ & cbar \\
\hline NP & 83305 & $11-15$ & 14.5 & $\% \mathrm{VM}$ & $\mathrm{T}$ & 83353 & $1,6-0-3$ & $*$ & cbar \\
\hline $\mathrm{NP}$ & 83311 & $11-15$ & 14.4 & $\% \mathrm{VM}$ & $\mathrm{T}$ & 83361 & $1,6-0-3$ & * & cbar \\
\hline NP & 83318 & $11-15$ & 13.9 & $\% \mathrm{VM}$ & $\mathrm{T}$ & 84003 & $1,6-0-3$ & * & cbar \\
\hline NP & 83325 & $11-15$ & 13.8 & $\% \mathrm{VM}$ & $\mathrm{T}$ & 84009 & $1,6-0-3$ & $*$ & cbar \\
\hline NP & 83332 & $11-15$ & 13.7 & $\% \mathrm{VM}$ & $\mathbf{T}$ & 84016 & $1,6-0-3$ & $*$ & cbar \\
\hline NP & 83339 & $11-15$ & 13.3 & $\% \mathrm{VM}$ & $\mathrm{T}$ & 84030 & $1,6-0-3$ & * & cbar \\
\hline NP & 83346 & $11-15$ & 12.9 & $\% \mathrm{VM}$ & $\mathrm{T}$ & 84037 & $1,6-0-3$ & * & cbar \\
\hline NP & 83353 & $11-15$ & 13.7 & $\% \mathrm{VM}$ & $\mathrm{T}$ & 84044 & $1,6-0-3$ & $*$ & cbar \\
\hline NP & 83361 & $11-15$ & 14.1 & $\% \mathrm{VM}$ & $T$ & 84052 & $1,6-0-3$ & $*$ & cbar \\
\hline NP & 84003 & $11-15$ & 13.0 & $\% \mathrm{VM}$ & $\mathrm{T}$ & 84058 & $1,6-0-3$ & $*$ & cbar \\
\hline NP & 84009 & $11-15$ & 13.9 & $\% \mathbf{V M}$ & $\mathrm{T}$ & 84065 & $1,6-0-3$ & * & cbar \\
\hline NP & 84016 & $11-15$ & 13.7 & $\% \mathrm{VM}$ & $\mathrm{T}$ & 84072 & $1,6-0-3$ & $*$ & cbar \\
\hline NP & 84030 & $11-15$ & $* * * *$ & $\% \mathrm{VM}$ & $\mathrm{T}$ & 84079 & $1,6-0-3$ & 0 & cbar \\
\hline NP & 84037 & $11-15$ & $* * * *$ & $\% \mathrm{VM}$ & $\mathrm{T}$ & 84086 & $1,6-0-3$ & 0 & cbar \\
\hline NP & 84044 & $11-15$ & $* * * *$ & $\% \mathrm{VM}$ & $\mathrm{T}$ & 84093 & $1,6-0-3$ & 0 & cbar \\
\hline NP & 84052 & 11-15 & $* * * *$ & $\% \mathrm{VM}$ & $\mathrm{T}$ & 84100 & $1,6-0-3$ & 0 & cbar \\
\hline NP & 84058 & $11-15$ & $* * * *$ & $\% \mathrm{VM}$ & $T$ & 84107 & $1,6-0-3$ & 0 & cbar \\
\hline NP & 84065 & $11-15$ & $* * * *$ & $\% \mathrm{VM}$ & $\mathbf{T}$ & 84114 & $1,6-0-3$ & 0 & cbar \\
\hline NP & 84072 & $11-15$ & $* * * *$ & $\% \mathrm{VM}$ & $\mathbf{T}$ & 84121 & $1,6-0-3$ & 0 & cbar \\
\hline NP & 84079 & $11-15$ & $* * * *$ & $\% \mathrm{VM}$ & $\mathbf{T}$ & 84128 & $1,6-0-3$ & 0 & cbar \\
\hline NP & 84086 & $11-15$ & $* * * *$ & $\% \mathrm{VM}$ & $\mathrm{T}$ & 84135 & $1,6-0-3$ & 0 & cbar \\
\hline NP & 84093 & $11-15$ & $* * * *$ & $\% \mathrm{VM}$ & $\mathbf{T}$ & 84142 & $1,6-0-3$ & 0 & cbar \\
\hline NP & 84100 & $11-15$ & $* * * *$ & $\% \mathrm{VM}$ & $\mathbf{T}$ & 84151 & $1,6-0-3$ & 0 & cbar \\
\hline NP & 84107 & $11-15$ & 13.6 & $\% \mathrm{VM}$ & $\mathrm{T}$ & 84156 & $1,6-0-3$ & 0 & cbar \\
\hline NP & 84114 & $11-15$ & 13.7 & $\% \mathrm{VM}$ & $\mathrm{T}$ & 84163 & $1,6-0-3$ & 0 & cbar \\
\hline NP & 84121 & $11-15$ & 13.3 & $\% \mathrm{VM}$ & $\mathrm{T}$ & 84170 & $1,6-0-3$ & 4 & cbar \\
\hline NP & 84128 & $11-15$ & 13.8 & $\% \mathrm{VM}$ & $\mathrm{T}$ & 84177 & $1,6-0-3$ & 3 & cbar \\
\hline NP & 84135 & $11-15$ & 12.9 & $\% \mathrm{VM}$ & $\mathrm{T}$ & 84184 & $1,6-0-3$ & 4 & cbar \\
\hline NP & 84142 & $11-15$ & 13.1 & $\% \mathrm{VM}$ & $\mathrm{T}$ & 84191 & $1,6-0-3$ & 4 & cbar \\
\hline NP & 84151 & $11-15$ & $* * * *$ & $\% \mathrm{VM}$ & $\mathbf{T}$ & 84198 & $1,6-0-3$ & 3 & cbar \\
\hline NP & 84156 & $11-15$ & $* * * *$ & $\% \mathrm{VM}$ & $\mathbf{T}$ & 84205 & $1,6-0-3$ & 4 & cbar \\
\hline$N P$ & 84163 & $11-15$ & $* * * *$ & $\% \mathrm{VM}$ & $\mathrm{T}$ & 84212 & $1,6-0-3$ & $*$ & cbar \\
\hline NP & 84170 & $11-15$ & $* * * *$ & $\% \mathrm{VM}$ & $\mathrm{T}$ & 84219 & $1,6-0-3$ & 4 & cbar \\
\hline NP & 84177 & $11-15$ & $* * * *$ & $\% \mathrm{VM}$ & $\mathrm{T}$ & 84226 & $1,6-0-3$ & 3 & cbar \\
\hline NP & 84184 & $11-15$ & $* * * *$ & $\% \mathrm{VM}$ & $\mathrm{T}$ & 83192 & $2,7-1.5-5$ & 5 & cbar \\
\hline NP & 84191 & $11-15$ & $* * * *$ & $\% \mathbf{V M}$ & $\mathrm{T}$ & 83200 & $2,7-1.5-5$ & 7 & cbar \\
\hline NP & 84198 & $11-15$ & 13.1 & $\% \mathrm{VM}$ & $\mathrm{T}$ & 83206 & $2,7-1.5-5$ & 8 & cbar \\
\hline & & & 13.1 & $\% \mathrm{VM}$ & $\mathrm{T}$ & 83213 & $2,7-1.5-5$ & 9 & cbar \\
\hline
\end{tabular}

Table B-1. Continued. 
Table B-1. Continued.

\begin{tabular}{|c|c|c|c|c|c|c|c|c|c|}
\hline Type & Date & Sample\# & Reading & Units & Type & Date & Sample\# & Reading & Units \\
\hline $\mathrm{T}$ & 83220 & $2,7-1.5-5$ & 8 & cbar & $\mathrm{T}$ & 83305 & $3,8-5-3$ & 15 & cbar \\
\hline $\mathrm{T}$ & 83227 & $2,7-1.5-5$ & 9 & cbar & $\mathrm{T}$ & 83311 & $3,8-5-3$ & 15 & cbar \\
\hline $\mathrm{T}$ & 83241 & $2,7-1.5-5$ & 6 & cbar & $\mathrm{T}$ & 83318 & $3,8-5-3$ & 15 & cbar \\
\hline $\mathrm{T}$ & 83250 & $2,7-1.5-5$ & 6 & cbar & $\mathrm{T}$ & 83325 & $3,8-5-3$ & 16 & cbar \\
\hline $\mathrm{T}$ & 83255 & $2,7-1.5-5$ & 7 & cbar & $\mathrm{T}$ & 83332 & $3,8-5-3$ & 0 & cbar \\
\hline $\mathrm{T}$ & 83262 & $2,7-1.5-5$ & 8 & cbar & $\mathrm{T}$ & 83339 & $3,8-5-3$ & * & cbar \\
\hline $\mathrm{T}$ & 83271 & $2,7-1.5-5$ & 8 & cbar & $\mathbf{T}$ & 83346 & $3,8-5-3$ & $*$ & cbar \\
\hline $\mathrm{T}$ & 83283 & $2,7-1.5-5$ & 8 & cbar & $\mathbf{T}$ & 83353 & $3,8-5-3$ & $*$ & cbar \\
\hline $\mathrm{T}$ & 83297 & $2,7-1.5-5$ & 8 & cbar & $\mathrm{T}$ & 83361 & $3,8-5-3$ & $*$ & cbar \\
\hline $\mathrm{T}$ & 83305 & $2,7-1.5-5$ & 9 & cbar & $\mathrm{T}$ & 84003 & $3,8-5-3$ & * & cbar \\
\hline$T$ & 83311 & $2,7-1.5-5$ & 9 & cbar & $\mathrm{T}$ & 84009 & $3,8-5-3$ & * & cbar \\
\hline $\mathrm{T}$ & 83318 & $2,7-1.5-5$ & 8 & cbar & $\mathrm{T}$ & 84016 & $3,8-5-3$ & $*$ & cbar \\
\hline $\mathbf{T}$ & 83325 & $2,7-1.5-5$ & 0 & cbar & $\mathrm{T}$ & 84030 & $3,8-5-3$ & $*$ & cbar \\
\hline $\mathrm{T}$ & 83332 & $2,7-1.5-5$ & 0 & cbar & $\mathrm{T}$ & 84037 & $3,8-5-3$ & $*$ & cbar \\
\hline $\mathrm{T}$ & 83339 & $2,7-1.5-5$ & $*$ & cbar & $\mathrm{T}$ & 84044 & $3,8-5-3$ & 0 & cbar \\
\hline $\mathrm{T}$ & 83346 & $2,7-1.5-5$ & $*$ & cbar & $\mathrm{T}$ & 84052 & $3,8-5-3$ & $*$ & cbar \\
\hline $\mathbf{T}$ & 83353 & $2,7-1.5-5$ & $*$ & cbar & $\mathrm{T}$ & 84058 & $3,8-5-3$ & 0 & cbar \\
\hline $\mathbf{T}$ & 83361 & $2,7-1.5-5$ & $*$ & cbar & $\mathrm{T}$ & 84065 & $3,8-5-3$ & 0 & cbar \\
\hline $\mathrm{T}$ & 84003 & $2,7-1.5-5$ & $*$ & cbar & $\mathrm{T}$ & 84072 & $3,8-5-3$ & 0 & cbar \\
\hline $\mathrm{T}$ & 84009 & $2,7-1.5-5$ & $*$ & cbar & $\mathbf{T}$ & 84079 & $3,8-5-3$ & 0 & cbar \\
\hline $\mathrm{T}$ & 84016 & $2,7-1.5-5$ & $*$ & cbar & $\mathrm{T}$ & 84086 & $3,8-5-3$ & 0 & cbar \\
\hline $\mathrm{T}$ & 84030 & $2,7-1.5-5$ & $*$ & cbar & $\mathrm{T}$ & 84093 & $3,8-5-3$ & 0 & cbar \\
\hline $\mathrm{T}$ & 84037 & $2,7-1.5-5$ & $*$ & cbar & $\mathrm{T}$ & 84100 & $3,8-5-3$ & 0 & cbar \\
\hline$T$ & 84044 & $2,7-1.5-5$ & 0 & cbar & $\mathrm{T}$ & 84107 & $3,8-5-3$ & 1 & cbar \\
\hline $\mathrm{T}$ & 84052 & $2,7-1.5-5$ & * & cbar & $\mathrm{T}$ & 84114 & $3,8-5-3$ & 1 & cbar \\
\hline $\mathrm{T}$ & 84058 & $2,7-1.5-5$ & $*$ & cbar & $\mathrm{T}$ & 84121 & $3,8-5-3$ & 1 & cbar \\
\hline $\mathrm{T}$ & 84065 & $2,7-1.5-5$ & $*$ & cbar & $\mathrm{T}$ & 84128 & $3,8-5-3$ & 2 & cbar \\
\hline $\mathrm{T}$ & 84072 & $2,7-1.5-5$ & 0 & cbar & $\mathrm{T}$ & 84135 & $3,8-5-3$ & 3 & cbar \\
\hline $\mathrm{T}$ & 84079 & $2,7-1.5-5$ & 0 & cbar & $\mathrm{T}$ & 84142 & $3,8-5-3$ & 3 & cbar \\
\hline $\mathrm{T}$ & 84086 & $2,7-1.5-5$ & 1 & cbar & $\mathrm{T}$ & 84151 & $3,8-5-3$ & 6 & cbar \\
\hline $\mathrm{T}$ & 84093 & $2,7-1.5-5$ & 0 & cbar & $\mathrm{T}$ & 84156 & $3,8-5-3$ & 6 & cbar \\
\hline $\mathrm{T}$ & 84100 & $2,7-1.5-5$ & 0 & cbar & $\mathrm{T}$ & 84163 & $3,8-5-3$ & 6 & cbar \\
\hline $\mathrm{T}$ & 84107 & $2,7-1.5-5$ & 0 & cbar & $\mathbf{T}$ & 84170 & $3,8-5-3$ & 15 & cbar \\
\hline $\mathrm{T}$ & 84114 & $2,7-1.5-5$ & 0 & cbar & $\mathbf{T}$ & 84177 & $3,8-5-3$ & 19 & cbar \\
\hline $\mathrm{T}$ & 84121 & $2,7-1.5-5$ & 0 & cbar & $\mathrm{T}$ & 84184 & $3,8-5-3$ & 20 & cbar \\
\hline $\mathrm{T}$ & 84128 & $2,7-1.5-5$ & 0 & cbar & $\mathrm{T}$ & 84191 & $3,8-5-3$ & 15 & cbar \\
\hline $\mathrm{T}$ & 84135 & $2,7-1.5-5$ & 0 & cbar & $\mathrm{T}$ & 84198 & $3,8-5-3$ & 17 & cbar \\
\hline $\mathrm{T}$ & 84142 & $2,7-1.5-5$ & 0 & cbar & $\mathrm{T}$ & 84205 & $3,8-5-3$ & 20 & cbar \\
\hline$T$ & 84151 & $2,7-1.5-5$ & 0 & cbar & $\mathrm{T}$ & 84212 & $3,8-5-3$ & $* *$ & cbar \\
\hline $\mathrm{T}$ & 84156 & $2,7-1.5-5$ & 0 & cbar & $\mathrm{T}$ & 84219 & $3,8-5-3$ & 8 & cbar \\
\hline $\mathbf{T}$ & 84163 & $2,7-1.5-5$ & 0 & cbar & $\mathrm{T}$ & 84226 & $3,8-5-3$ & 8 & cbar \\
\hline $\mathrm{T}$ & 84170 & $2,7-1.5-5$ & 5 & cbar & $\mathbf{T}$ & 83192 & $4,9-6-5$ & 16 & cbar \\
\hline $\mathrm{T}$ & 84177 & $2,7-1.5-5$ & 5 & cbar & $\mathbf{T}$ & 83200 & $4,9-6-5$ & 15 & cbar \\
\hline $\mathrm{T}$ & 84184 & $2,7-1.5-5$ & 5 & cbar & $\mathbf{T}$ & 83206 & $4,9-6-5$ & 19 & cbar \\
\hline $\mathrm{T}$ & 84191 & $2,7-1.5-5$ & 4 & cbar & $\mathrm{T}$ & 83213 & $4,9-6-5$ & 20 & cbar \\
\hline$T$ & 84198 & $2,7-1.5-5$ & 4 & cbar & $\mathrm{T}$ & 83220 & $4,9-6-5$ & 20 & cbar \\
\hline $\mathrm{T}$ & 84205 & $2,7-1.5-5$ & 3 & cbar & $\mathbf{T}$ & 83227 & $4,9-6-5$ & 20 & cbar \\
\hline $\mathrm{T}$ & 84212 & $2,7-1.5-5$ & * & cbar & $\mathrm{T}$ & 83241 & $4,9-6-5$ & 13 & cbar \\
\hline $\mathrm{T}$ & 84219 & $2,7-1.5-5$ & 3 & cbar & $\mathrm{T}$ & 83250 & $4,9-6-5$ & 11 & cbar \\
\hline $\mathrm{T}$ & 84226 & $2,7-1.5-5$ & 4 & cbar & $\mathbf{T}$ & 83255 & $4,9-6-5$ & 12 & cbar \\
\hline $\mathrm{T}$ & 83200 & $3,8-5-3$ & 22 & cbar & $\mathbf{T}$ & 83262 & $4,9-6-5$ & 14 & cbar \\
\hline $\mathbf{T}$ & 83206 & $3,8-5-3$ & 24 & cbar & $\mathbf{T}$ & 83271 & $4,9-6-5$ & 15 & cbar \\
\hline $\mathrm{T}$ & 83213 & $3,8-5-3$ & 29 & cbar & $\mathbf{T}$ & 83283 & $4,9-6-5$ & 15 & cbar \\
\hline $\mathrm{T}$ & 83220 & $3,8-5-3$ & 28 & cbar & $\mathrm{T}$ & 83297 & $4,9-6-5$ & 15 & cbar \\
\hline $\mathrm{T}$ & 83227 & $3,8-5-3$ & 27 & cbar & $\mathbf{T}$ & 83305 & $4,9-6-5$ & 15 & cbar \\
\hline $\mathrm{T}$ & 83241 & $3,8-5-3$ & 13 & cbar & $\mathrm{T}$ & 83311 & $4,9-6-5$ & 16 & cbar \\
\hline $\mathbf{T}$ & 83250 & $3,8-5-3$ & 13 & cbar & $\mathrm{T}$ & 83318 & $4,9-6-5$ & 16 & cbar \\
\hline $\mathrm{T}$ & 83255 & $3,8-5-3$ & 15 & cbar & $\mathrm{T}$ & 83325 & $4,9-6-5$ & 17 & cbar \\
\hline $\mathrm{T}$ & 83262 & $3,8-5-3$ & 16 & cbar & $\mathrm{T}$ & 83332 & $4,9-6-5$ & 0 & cbar \\
\hline$T$ & 83271 & $3,8-5-3$ & 16 & cbar & $\mathrm{T}$ & 83339 & $4,9-6-5$ & $*$ & cbar \\
\hline $\mathbf{T}$ & 83283 & $3,8-5-3$ & 14 & cbar & $\mathrm{T}$ & 83346 & $4,9-6-5$ & $*$ & cbar \\
\hline $\mathbf{T}$ & 83297 & $3,8-5-3$ & 16 & cbar & $\mathrm{T}$ & 83353 & $4,9-6-5$ & $*$ & cbar \\
\hline
\end{tabular}


Table B-1. Continued.

\begin{tabular}{|c|c|c|c|c|c|c|c|c|c|}
\hline Type & Date & Sample\# & Reading & Units & Type & Date & Sample\# & Reading & Units \\
\hline $\mathrm{T}$ & 83361 & $4,9-6-5$ & $*$ & cbar & $T$ & 83283 & $5,10-11-10$ & 11 & cbar \\
\hline $\mathrm{T}$ & 84003 & $4,9-6-5$ & $*$ & cbar & $\mathrm{T}$ & 83297 & $5,10-11-10$ & 10 & cbar \\
\hline $\mathrm{T}$ & 84009 & $4,9-6-5$ & $*$ & cbar & $\mathbf{T}$ & 83305 & $5,10-11-10$ & 12 & cbar \\
\hline $\mathrm{T}$ & 84016 & $4,9-6-5$ & $*$ & cbar & $\mathrm{T}$ & 83311 & $5,10-11-10$ & 13 & cbar \\
\hline $\mathrm{T}$ & 84030 & $4,9-6-5$ & $*$ & cbar & $\mathrm{T}$ & 83318 & $5,10-11-10$ & 13 & cbar \\
\hline$T$ & 84037 & $4,9-6-5$ & $*$ & cbar & $\mathbf{T}$ & 83325 & $5,10-11-10$ & 14 & cbar \\
\hline $\mathrm{T}$ & 84044 & $4,9-6-5$ & 4 & cbar & $\mathbf{T}$ & 83332 & $5,10-11-10$ & 0 & cbar \\
\hline $\mathrm{T}$ & 84052 & $4,9-6-5$ & 4 & cbar & $\mathbf{T}$ & 83339 & $5,10-11-10$ & $*$ & cbar \\
\hline $\mathrm{T}$ & 84058 & $4,9-6-5$ & 5 & cbar & $\mathrm{T}$ & 83346 & $5,10-11-10$ & $*$ & cbar \\
\hline$T$ & 84065 & $4,9-6-5$ & 6 & cbar & $\mathbf{T}$ & 83353 & $5,10-11-10$ & * & cbar \\
\hline$T$ & 84072 & $4,9-6-5$ & 7 & cbar & $T$ & 83361 & $5,10-11-10$ & $*$ & cbar \\
\hline $\mathrm{T}$ & 84079 & $4,9-6-5$ & 8 & cbar & $\mathbf{T}$ & 84003 & $5,10-11-10$ & * & cbar \\
\hline $\mathrm{T}$ & 84086 & $4,9-6-5$ & 11 & cbar & $T$ & 84009 & $5,10-11-10$ & * & cbar \\
\hline $\mathrm{T}$ & 84093 & $4,9-6-5$ & 12 & cbar & $\mathbf{T}$ & 84016 & $5,10-11-10$ & $*$ & cbar \\
\hline $\mathrm{T}$ & 84100 & $4,9-6-5$ & 14 & cbar & $\mathrm{T}$ & 84030 & $5,10-11-10$ & $*$ & cbar \\
\hline $\mathrm{T}$ & 84107 & $4,9-6-5$ & 14 & cbar & $T$ & 84037 & $5,10-11-10$ & $*$ & cbar \\
\hline $\mathrm{T}$ & 84114 & $4,9-6-5$ & 9 & cbar & $\mathbf{T}$ & 84044 & $5,10-11-10$ & 0 & cbar \\
\hline$T$ & 84121 & $4,9-6-5$ & 16 & cbar & $\mathrm{T}$ & 84052 & $5,10-11-10$ & 0 & cbar \\
\hline $\mathbf{T}$ & 84128 & $4,9-6-5$ & 15 & cbar & $\mathrm{T}$ & 84058 & $5,10-11-10$ & 0 & cbar \\
\hline$T$ & 84135 & $4,9-6-5$ & 16 & cbar & $\mathrm{T}$ & 84065 & $5,10-11-10$ & 0 & cbar \\
\hline$T$ & 84142 & $4,9-6-5$ & 14 & cbar & $\mathrm{T}$ & 84072 & $5,10-11-10$ & 0 & cbar \\
\hline$T$ & 84151 & $4,9-6-5$ & 16 & cbar & $\mathrm{T}$ & 84079 & $5,10-11-10$ & 1 & cbar \\
\hline$T$ & 84156 & $4,9-6-5$ & 16 & cbar & $T$ & 84086 & $5,10-11-10$ & 2 & cbar \\
\hline$T$ & 84163 & $4,9-6-5$ & 16 & cbar & $\mathrm{T}$ & 84093 & $5,10-11-10$ & 2 & cbar \\
\hline$T$ & 84170 & $4,9-6-5$ & 15 & cbar & $\mathrm{T}$ & 84100 & $5,10-11-10$ & 2 & cbar \\
\hline $\mathrm{T}$ & 84177 & $4,9-6-5$ & 15 & cbar & $\mathrm{T}$ & 84107 & $5,10-11-10$ & 2 & cbar \\
\hline $\mathbf{T}$ & 84184 & $4,9-6-5$ & 13 & cbar & $\mathrm{T}$ & 84114 & $5,10-11-10$ & 1 & cbar \\
\hline $\mathrm{T}$ & 84191 & $4,9-6-5$ & 14 & cbar & $\mathrm{T}$ & 84121 & $5,10-11-10$ & 3 & cbar \\
\hline $\mathrm{T}$ & 84198 & $4,9-6-5$ & 16 & cbar & $\mathrm{T}$ & 84128 & $5,10-11-10$ & 4 & cbar \\
\hline $\mathrm{T}$ & 84205 & $4,9-6-5$ & 19 & cbar & $T$ & 84135 & $5,10-11-10$ & 4 & cbar \\
\hline$T$ & 84212 & $4,9-6-5$ & $* *$ & cbar & $\mathrm{T}$ & 84142 & $5,10-11-10$ & 3 & cbar \\
\hline$T$ & 84219 & $4,9-6-5$ & 15 & cbar & $\mathrm{T}$ & 84151 & $5,10-11-10$ & 5 & cbar \\
\hline$T$ & 84226 & $4,9-6-5$ & 12 & cbar & $\mathrm{T}$ & 84156 & $5,10-11-10$ & 4 & cbar \\
\hline$T$ & 83192 & $5,10-11-10$ & 6 & cbar & $T$ & 84163 & $5,10-11-10$ & 4 & cbar \\
\hline$T$ & 83200 & $5,10-11-10$ & 6 & cbar & $\mathrm{T}$ & 84170 & $5,10-11-10$ & 4 & cbar \\
\hline $\mathrm{T}$ & 83206 & $5,10-11-10$ & 5 & cbar & $\mathrm{T}$ & 84177 & $5,10-11-10$ & 4 & cbar \\
\hline $\mathrm{T}$ & 83213 & $5,10-11-10$ & 11 & cbar & $\mathbf{T}$ & 84184 & $5,10-11-10$ & 2 & cbar \\
\hline $\mathrm{T}$ & 83220 & $5,10-11-10$ & 8 & cbar & $\mathrm{T}$ & 84191 & $5,10-11-10$ & 4 & cbar \\
\hline $\mathrm{T}$ & 83227 & $5,10-11-10$ & 11 & cbar & $\mathrm{T}$ & 84198 & $5,10-11-10$ & 3 & cbar \\
\hline $\mathrm{T}$ & 83241 & $5,10-11-10$ & 6 & cbar & $T$ & 84205 & $5,10-11-10$ & 1 & cbar \\
\hline $\mathrm{T}$ & 83250 & $5,10-11-10$ & 6 & cbar & $T$ & 84212 & $5,10-11-10$ & $*$ & cbar \\
\hline $\mathrm{T}$ & 83255 & $5,10-11-10$ & 9 & cbar & $\mathrm{T}$ & 84219 & $5,10-11-10$ & 2 & cbar \\
\hline$T$ & 83262 & $5,10-11-10$ & 10 & cbar & $\mathrm{T}$ & 84226 & $5,10-11-10$ & 2 & cbar \\
\hline
\end{tabular}

